

$$
\begin{gathered}
j \hat{n}+,+2, \ldots, c \\
-1
\end{gathered}
$$

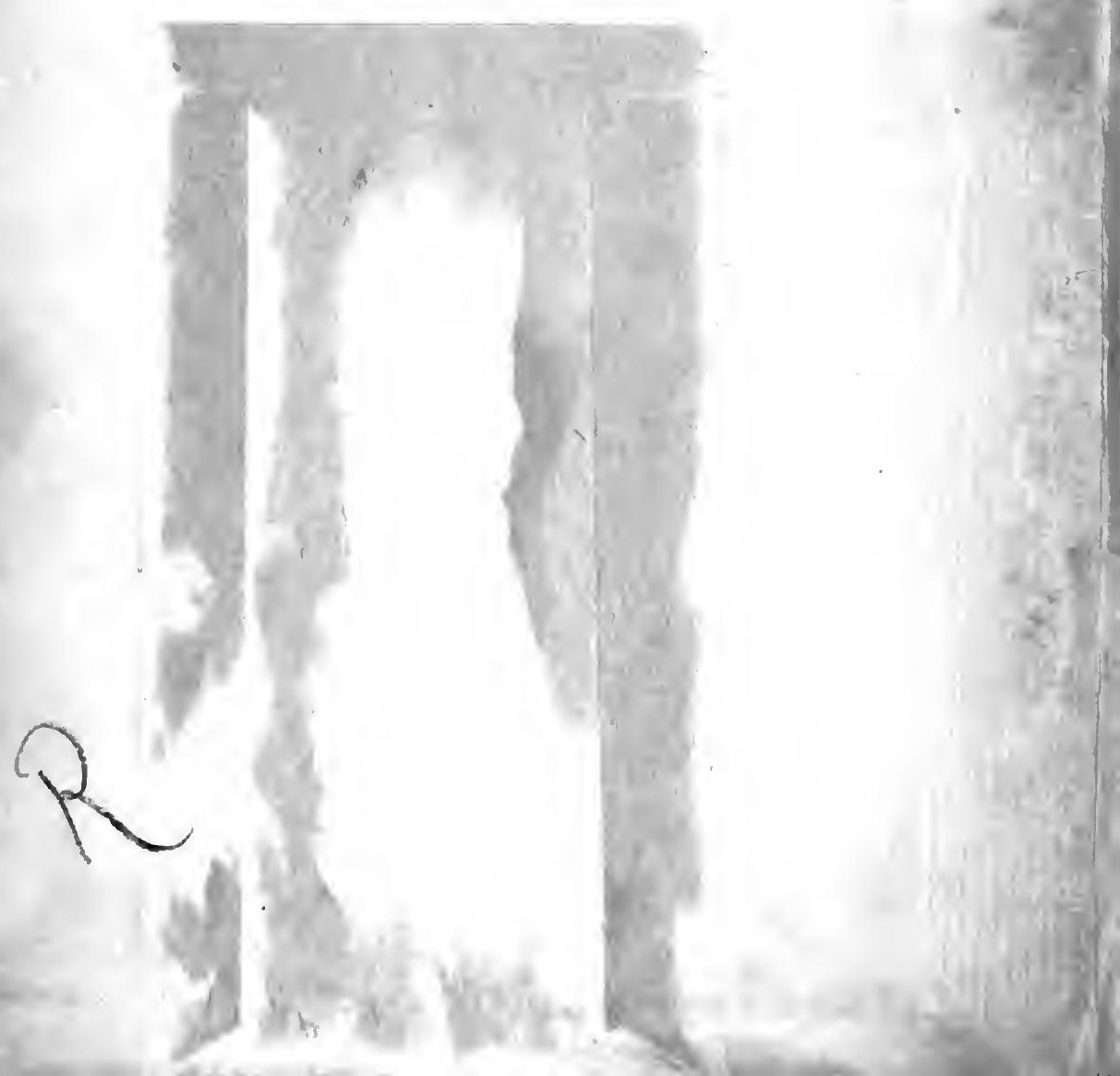



Guiana, the West Indies, Ceylon, and Mauritius, to formulate some verf, chefinite principles of THe Broad Stoxe of Ermine. By Sir Charles policy, policy being the means adopted for giving Bruce. Macmillan and Co. Two Vols. 30 s. effect locally to that fundamental conception of
net.

"The Bload Stone of Empire" is a book which ought to appeal to many who have como from beyond the seas to attend the Coronation, as well as to home-staying Englishmen. It is a valuable contribution to the political study of the tropical Dependencies, whose importance in the Imperial system is nowadays too often overlooked. Sir Charles Bruce was well qualified tor his task by the experienco gained in a long and honourable career as administrator, and by an aptitude for viewing particular or local developments in their relation to the system of Colonial gorermment as a whole.

The Broad Stone of the Empire is explained to be the principle of civil and religious liberty for every citizen, which it is the aim of British policy to establish in every land under the Flag, by methods adapted to the rarying local conditions. Though the sub-title of the book is "Problems of Crown Cro" Administration" the author travels orer a wide rield in order to reach his subject-matter proper. Of the two massive but excellently printed and well-indexed volumes about a third is clevoted to an introductory clisquisition on the growth of British policy in its Imperial aspects, involving some examination of its domestic aspects also, by way of showing how the Broad Stone came to be recognised. In a very interesting style, and with brevity considering the masnitude of the subject, Sir Charles Bruce describes the protracted social and political revolution which changed the face of England in the course of the last century, and shows how the Colonial policy of the country passed through a series of corresponding phases, including the dismal phase of making ready to cut the painter.

The final result seems to be, in regard to the tropical Colonies, that British policy is now settling down, though not without occasional spasms of reaction, to the working out of certain main principles which are gaining recognition. Originally the tropical Colonies wel'e ralued as a source of fabulous wealth in precious metals and stones, and then for the profits of a trade based on slare labour. In that period the Dutch were found willing to cede New York in exchange for the British colony of Surinam, in Guiana, and in England it was seriously proposed that France might be aslied to accept Canada in exchange for the little island of Guadeloupe. The abolition of slavery was a severe blow to the trade based on slave labour. It encouraged the notion that these Coinies were a source of unrequited expense and risk to the Mother Country. With the reviral of Imperialist ideas-which Sir Charles Bruce marks by the foundation of the Colonial Institute in 1868 and Disraeli's wellknown speech in 1872 - began the third period of policy in regard to tropical Colonies, namely, that of " beneficial occupation," implying the exploitation of natural resources by means of free coloured labour under the direction of British brains and capital. As is justly remarlied, this phase of the Colonial system is much more raluble in opportunities of employment for the the S'tate's duty which is denoted in the title of the book. He is convinced that self-government of the type obtaining in the Self-governing Dominions is for ever inapplicable to the tropical Colcnies, because their peculiar economic conditions preclude the social equality which is th ethical basis of democracy. In the tropics th. white man has not the physical aptitude fo manual labour, which thus becomes assigned exclusively to the coloured races; while those races are deficient in the intellectual aptituder for organising or controlling industry on the modern scale. With this racial division of function, social equality, and therefore democracy, becomes impracticable, which explains the spontaneous reversion from representative to Crown government in some of the West Indian Colonies.

Assuming it to be the cluty of the Gorernment to attend impartially to the interests of all classes of the community, the question arises as to the best means of securing full and fair representation of all sections in those Colonies whicl have Legislative Councils. Sir Charles Bruef pleads for the expedient of nomination as being generally superior to that of election. Election by terpitorial constituencies does not ensur. either that all sections shall be duly representer or that the representatires chosen shall br typical of the best qualities of the sections or whose sufirages they depend. The introduction, again, of an elected element in the Council tends to prevent the oficial majority from ferling-as they otherwise do-that they represent the whole community.

Sir Charles Bruce illustrates his points forcibly from his experience in Mauritius, a Colony which, with British Guiana, has supplied hin with abundant material for his exceedingly usefu account of the origin and growth of Indian im migration and the problems it presents. Wh. Indian immigration has undoubtedly save Nauritius and other " sugar"' Colonies, givin! them an opportunity of continuous development it has complicated the question of political righ in a manner antagonistic to the extension clectire institutions. It seems to be significan - Sir Charles Bruce gives the facts withorm pointing the conclusion-that the antipathy of the Mauritians to Indian representation in the Government did not arise until after a considerable number of the Indian immigrants had acquired large and permanent interests in the island. So long as the Indians were "coolies" only, their" right to representa. tion does not appear to have been disputed.

Of special interest to Governors, present and prospective, is the question of continuity of policy. It is obviously desirable that a new Governor should not bastily reverse the policy of his pledecessor. Bnt how is the due assurance of continuity to be reconciled with the equally raluable rule, seldom violated without disaster, of trusting the man on the spot? It seems clear that the Colonial Office is unfit to exercise the responsibility either of forbidding a reversal of policy or of decreeing one. It has sometimes happened that junior cierts in the Ofice, utterly ignorant and inexperienced, hare in effect exercised the power of hampering 
of the Department, these gentlemen likewise are deficient in the local lnowledge necessary for forming an intelligent judgment. Too often questions of administration have been decided on the strength of so-called " principles," which have becn deduced from the peculiar and totally different conditions of some other Colony. Nor, if it were practicable for everything to come before the Secretary of State himself, is it customary for that exalted functionary to be any better qualified by knowledge and sympathy than his Departmental advisers. To mitigate the difficulty Sir Charles Bruce advocates the institution at the Colonial Office of an Advisory Council, on which ex-Governors might serve for the first few years after their retirement. The present time, with proposals of reorganisation so much to the fore seems opportune for considering whether the reduced Colonial Office should be strengthened with some such Advisory Council, representing all the Empire Orerseas.

"Expansion" is a familiar term in the vocabulary of Tmperialism, but in this book it is given a new and appropriate significance. 'To the author the policy of expansion means, not the acquisition of new territory, but the fuller exploitation, with the fullest aid of modern science, of the territory already acquired. Perhaps the most stimulating part of the book is that which describes what has been done of recent years, and suggests how much more night be done, in the way of utilising the natural resources of the Crown Colonies. In this connection frequent reference is made to $\mathrm{Mr}$. Chamberlain, to whom is due much of the credit for imbuing the modern Colonial Office with a sense of the importance of economic development.

Through such books as this Englishmen may in time begin to understand the nature of the hold which Mr. Chamberlain, during his eareer at the Colonial Office, acquired on the esteem and affection of so many of those beyond the seas who were dependent upon his official support and encouragement. It was indeed a new era. Among the subsidiary institutions of which Sir Charles Bruce describes the origin and growth, the Imperial Department of Agriculture for the West Indies, the Schools of Tropical Medicine, and the Colonial Nursing Association are monuments cere perennius to $\mathrm{Mr}$. Chamberlain. With his accession there seems to have begun a period of relief from the rule of junior clerks, red tape, and cast-iron " principle." When Sir Charles Bruce was at his wits' end to tide the development policy in Grenada orer a crisis, Lord Ripon finally decided with duo deliberation that the proposed expedient of putting an export duty on 
cocoa would be inconsistent with accepted fiscal principles. (Was there a "cocoa Press" or only a cocoa "lobby" in those days?) But on Mr. Chamberlain's accession the Governor ventured to reopen the question and pleaded for a speedy reply. It came by cable: "Consent to export duty." How any Minister not hopelessly enslaved to sectional interests at home or to the mere pedantry of a fiscal doctrine could ever have resisted the convincing arguments put forward by the man on the spot is difficult to understand.

Iu a chapter on fiscal policy attention is called to the striking fact that throughout the Crown Colonies the expedient of a Customs tariff has been adopted and retained as the best instrument of revenue; because it apportions the tax to ability to pay and relatively to other taxes is cheap in cost of collection. From the standpoint of Colonial Office practice the tariff system of the United Kingdom is atrocious ; two of its main features being that the only articles taxed are articles of which the poor man consumes as much as his rich neighbour, and that the duty is specific instead of ad valorem, so that the poor man pays 100 per cent. on his cheap tea while the rich man pays 10 per cent. on the superior quality. But in the Crown Colonies no question of Protection intervenes, because the articles imported are not, generally speaking, of a kind locally produced. It is interesting to note that in Sir Charles Bruce's opinion there is no serious obstacle to the establishment of a Zollverein, or complete free trade, except where excise duties balance import duties, between this country and the Crown Colonies.

No doubt Sir Charles Bruce has somewhat spoiled the symmetry and has increased the bulk of his book by recounting in considerable detail various epir 3 in his own administrative career. But he seen. to have adopted this course partly at any rate for the sake of putting on record the valuable services of various subordinates, typical of the men who really carry on the work of the Empire, but who are seldom rewarded with any form of public recognition. If all emeriti Governors would similarly record their more important experiences and their matared conclusions, there would soon be less excuse than at present for the lack of public interest in the Crown Colonies, and of intelligent criticism of the administrativo system. 


\section{Digitized by the Internet Archive in 2008 with funding from Microsoft Corporation}


THE BROAD STONE OF EMPIRE 


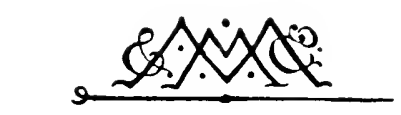

MACMILLAN AND CO., Limited

LONDON - BOMBAY - CALCUTTA MELBOURNE

THE MACMILLAN COMPANY

NEW YORK - BOSTON · CHICAGO

ATLANTA - SAN FRANCISCO

THE MACMILlaN CO. OF CANADA, Ltd. TORONTO 


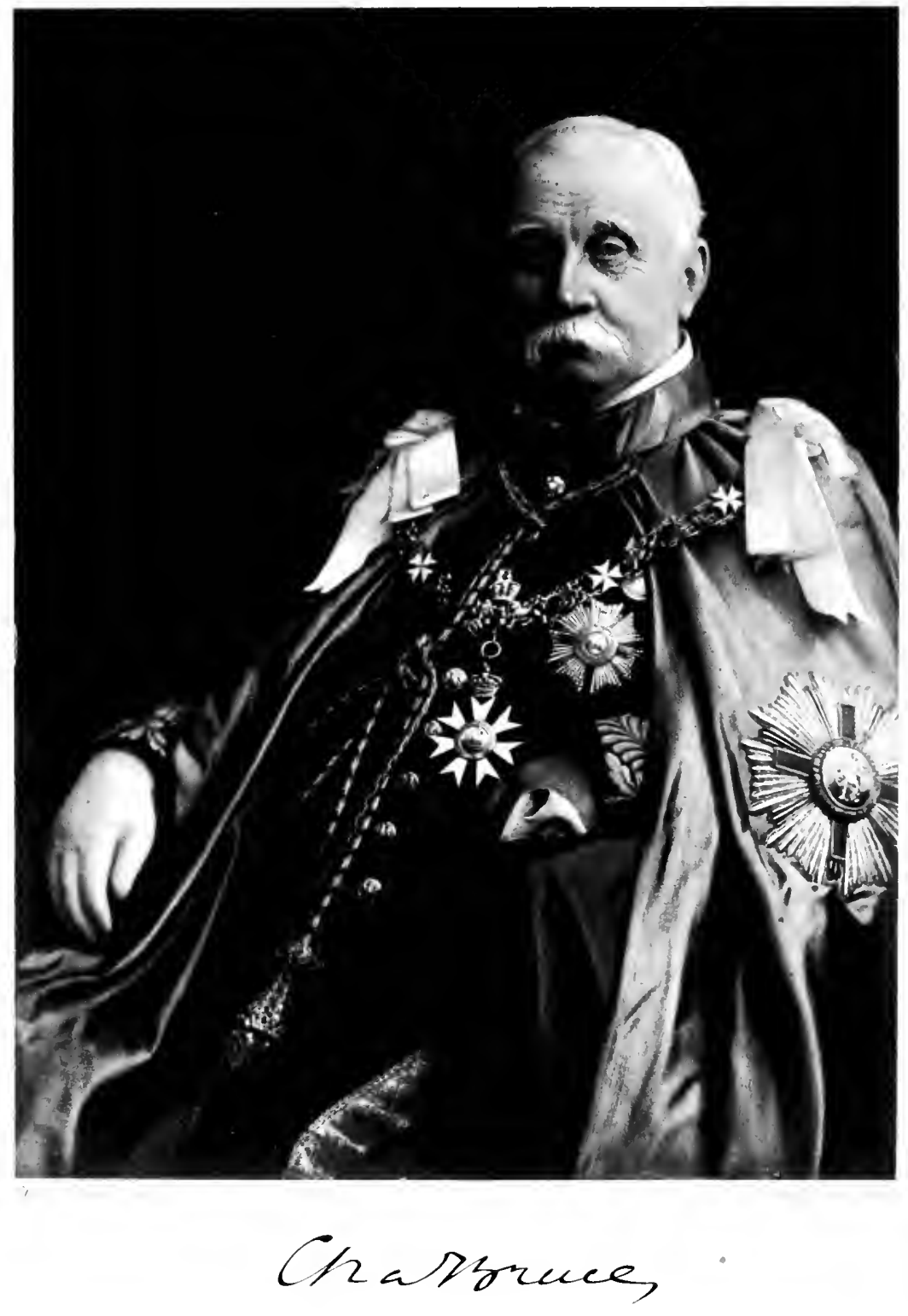




\title{
THE BROAD STONE OF EMPIRE
}

\author{
PROBLEMS OF \\ CROWN COLONY ADMINISTRATION
}

WITH RECORDS OF PERSONAL EXPERIENCE

BY

SIR CHARLES BRUCE, G.C.M.G.

VOL. I

It is broad in respect to its principles and its law, "latum mandatum tuum nimis"; broad in acknowledging distinctly and broadly the eternal truths of religion, that all men are equal before God.

The 3road stone of Fionour.

By Kenelm Henry Digiy.

WITH MAPS

MACMILLAN AND COO, LIMITED

ST. MARTIN'S STREET, LONDON

I9IO 


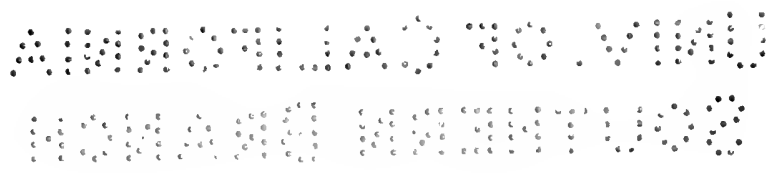

GLASGOW: PRINTED AT THE UNIVERSITY PRESS

BY ROBERT MACLEHOSE AND CO. LTD. 


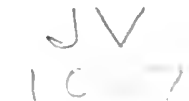

TO HIS MAJESTY'S SUBJECTS

IN THE

CROWN COLONIES

AMIONG WHOM HE HAS LIVED AND LABOURED

THIS WORK IS DEDICATED

BY THE AUTHOR 



\title{
CONTENTS
}

\author{
VOL. I
}

PREFACE

- pp. xi-xxxiv

\section{CHAPTER I \\ THE CROWN COLONIES}

Agricultural resources-Forest resources-Mineral resources-Power resources-International rivalry for the control of the tropicsAdaptation of principles of British policy to administrative problems

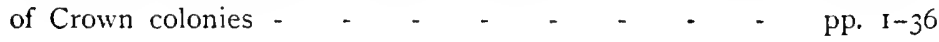

\section{CHAPTER II}

OUR NATIONAL POLICY, I8I5-1868

Conditions of national life which determined the policy of early Victorian era-Social and political disorders - - pp. 37-56

\section{CHAPTER III}

OUR NATIONAL POLICY, 1815-1868-Continued

Social and political Reform-Law-Religion-Education-HealthLabour-Commerce 
CHAPTER IV

OUR COLONIAL POLICY, I8I5-1868.

Stages of our Colonial Policy-North America-South AfricaAustralia and New Zealand-India-Tropical colonies pp. 92-I45

\section{CHAPTER V}

\section{OUR IMPERIAL POLICY, 1868 AND AFTER}

Bearing of American Civil IVar on our colonial policy-Expansionist policy of United States-Foundation of Royal Colonial InstituteLord Beaconsfield and the New Imperialism - - pp. 146-I69

\section{CHAPTER VI}

THE COLONIAL OFFICE

Gradual emancipation of self-governing colonies from Colonial Office-Mr. Chamberlain and the new system of administrative control over Crown colonies-Continuity of policy-Advisory Council -

\section{CHAPTER VII}

\section{THE COLONIAL GOVERNOR}

Evolution of the Colonial Governor-Conditions and qualificationsPrinciples of successful administration - - - - pp. 203-225

\section{CHAPTER VIII}

\section{LOCAL GOVERNMENT}

Classification of Constitutions of Crown Colonies-Constitution of Ceylon as a type of Crown Colony Legislature-Despatch of Duke of Buckingham explaining essential principles of Crown Colony Government and introducing an elective element-The system in Jamaica-The system in Mauritius-Composition, practical working and results of reformed constitution of Mauritius - - pp. 226-26I 


\section{CHAPTER IX}

\section{LAW}

Origins of Law in the Crown colonies-Legislative needs of the Crown colonies-Consolidation and codification of old LawsApplication of new Laws-Uniformity of Legislation-Revision of Laws in British Guiana-Windward Islands-Mauritius-the Criminal Code-the Royal Prerogative-Society of Comparative Legislation

- pp. $262-305$

\section{CHAPTER X}

\section{LABOUR}

Results of abolition of slavery in Crown colonies-ImmigrationColonial Interests-Interests of the Immigrants-Interests of the Government of India-System of Immigration-Immigration in British Guiana-Dr. Comins' Report-Immigration in Mauritius - Sir Muir Mackenzie's Report-Constituent elements and civil status of Asiatic population - - _ _ - - - pp. 306-369

\section{CHAPTER XI}

\section{RACE}

Association of Europeans, Africans, and Asiatics in beneficial occupation of the tropics-White capital and coloured labourthe Asiatic-the Red Indian-the Negro-the Creole-The Native as potential citizen-Amalgamation of races - - pp. 370-396

\section{CHAPTER XII}

\section{HEALTH}

Some Imperial aspects of tropical disease-Mr. Chamberlain and the health of the Empire-Foundation of Schools of Tropical Medicine-Auxiliary agencies-Study of Tropical Diseases in Medical Schools of United Kingdom-An Imperial Pharmacopoeia -Colonial Nursing Association-Results - - - pp. 397-461 


\section{CHAPTER XIII}

HEALTH-Continued

Personal experience of tropical diseases-in Mauritius-in Ceylonin British Guiana-in the Windward Islands-Surra and Malaria in Mauritius-Quarantine Legislation- - - - - pp. 461-497

\section{CHAPTER XIV \\ HEALTH-Continued}

Tropical diseases that have their origin in civilisation-Drink Traffic -Opium Traffic - pp. 498-51 I

Portrait of Sir Charles Bruce, G.C.M.G.

From a Photograph by W. \& D. Downey - - Frontispiece

\section{MAPS, AT END OF VOLUME}

MaP OF WORLd, SHOWing THE BRITISH EMPIRE

THE UNITED KINGDOM AND DEPENDENCIES WHOLLy OR PARTLY WITHIN THE TROPICS 


\section{PREFACE}

IT is getting to be generally recognised that the accepted classification of the constituent elements of the British Empire in three groups, - the United Kingdom, the Colonies and India, - is becoming obsolete. The laws of political and economic geography demand a more scientific classification in accordance with the natural factors of distinction between the temperate zones and the tropics, these factors having already determined a political cleavage between two groups of colonies under the designation of selfgoverning and Crown colonies. It is probable that before long this cleavage will be generally expressed by substituting the term Dominions for self-governing colonies, and in anticipation of this usage, the constituent parts of the Empire may be grouped approximately as exhibited in this table: ${ }^{1}$

\begin{tabular}{lcrr} 
& Area in Square Miles. & \multicolumn{1}{c}{ Population. } \\
United Kingdom, & I 20,000 & $44,500,000$ \\
Dominions, - & - & $7,500,000$ & I $8,000,000$ \\
Crown Colonies, & - & I, 860,000 & $40,000,000$ \\
India, - - & I, $\$ 00,000$ & $300,000,000$
\end{tabular}

${ }^{1}$ The figures of area and population are only approximate estimates. I have been astonished, in the course of my work, at the conflict of estiniates in official and what claim to be authentic sources of information. 
A glance at the map will show that the territory of the Dominions does not lie wholly in temperate zones; a considerable area of Australia is tropical. Nor do all the Crown colonies lie in the tropics. The statistical abstract which forms an appendix to this work shows that the Crown colonies include places in temperate zones which have importance for military and naval purposes, such as Gibraltar, Malta and Cyprus, or have not received institutions of self-government for other reasons, such as the Falkland Islands. But, broadly speaking, the grant of self-government has been conditioned by the natural elements of distinction between the tempcrate zones and the tropics. In March, 1905, I read a paper at a meeting of the Royal Colonial Institute on The Crown Colonies and Places, including in the term all the component parts of the Empire lying outside of the United Kingdom, the self-governing colonies, and India. It was, I believe, the first time that the phrase was employed. As I explained, it was suggested by the terms of the Colonial Loans Act, 1899, which, for the purposes of the Act, defined certain Dependencies and States as Crown Places. I commenced my paper by reference to the colonial policy of the earlier decades of the Victorian era, a policy summed up in John Stuart Mill's proposition that "England would be in a much stronger and more dignified position without her colonies than with them," and in the corollary formula, attributed to Cobden, that "John Bull had for the next fifty years the task set him of cleansing his house of its useless stuff-the Army and Navy." After indicating the causes that 
had brought about a reversal of this policy, and exhibited to the jealous nations of the West an Empire covering one-fifth of the earth's surface, with a population of one-fifth of the inhabitants of the globe, I showed that the process of expansion had discovered a broad line of demarcation between the economic conditions of the temperate zones and the tropics, and that this line had determined a parallel line of political cleavage between the self-governing and the Crown colonies. I then proceeded to discuss the problems of British administration in the Crown Colonies and Places. They may conveniently be summarised as problems of an appropriate form of government, appropriate laws, an appropriate population, appropriate methods of development, appropriate fiscal systems, and an appropriate scheme of defence.

The exigencies of the occasion did not allow me to do more than indicate the nature of these problems, but in the years that have since elapsed, in my endeavour to bring home to my countrymen, and especially to the industrial classes, the importance of their interest in the Crown colonies, I have dealt with them in detail, by such methods as I have found available: by lectures and addresses to learned societies, schools of tropical medicine, working men's colleges, settlements, and literary associations, as well as by many contributions to reviews, periodicals and the daily press. Some time ago it was suggested to me that I might co-ordinate and expand my scattered contributions to a knowledge of the subject, and place the results of my experience on permanent record. 
This is the origin of my present work, and I am encouraged to hope that it may be found justified by a growing appreciation of the value of our Crown colonies, and an increasing interest in the methods by which they are governed and economically developed. The causes of this growing interest are not far to seek. In the first place, the foundation of the Union of South Africa has finally removed the whole group of self-governing colonies or Dominions from the area of exercise of the functions of administration by the Government of the United Kingdom. The problems of administration which I have enumerated are, as I shall endeavour in the course of my work to make clear, common to every unit of the Empire, but the Government of the United Kingdom has no more power to deal with them in the Dominions than it has in foreign countries. I yield to no one in my admiration of the splendour and strength accruing to the Empire from the loyalty of the Dominions; but we are bound in the common interests of the Empire to recognise the interpretation they frankly and proudly place on the term.

The policy of the self-governing colonies common to each has long been based on their desire to remain in the British Empire; to build up a nationality of their own, each in its own way; and to increase their autonomy as regards the United Kingdom. The ideal of their policy has been, I think fairly, paraphrased by saying that the desire of the self-governing colonies is to form with the United Kingdom a partnership on the basis of equality as nations. The result of this policy has 
been to attach to the loyalty of the self-governing colonies certain limitations on which they insist. Their loyalty to the Crown is limited only by the conditions which determine the relations of subjects to the Crown in the United Kingdom and wherever constitutional government exists. Their loyalty to the Empire is conditioned by a claim to an association of partnership in control over the relations of the different self-governing colonies to each other and to the United Kingdom, as well as to foreign States. To the Imperial Parliament they disclaim allegiance altogether, holding that, as autonomous nations, the Parliament of the United Kingdom has no more right of control over their internal affairs than their own parliaments have over the internal affairs of the United Kingdom. The position was clearly defined during the passage through Parliament of the Union of South Africa Bill. His Majesty's Government declared Parliament impotent to assert, and precluded even from advocating, what they nevertheless admitted to be a just cause and a cause of imperial concern-the claims of British subjects of non-European birth within the Union to the protection of the Government of the United Kingdom.

This formal recognition of the claim of the selfgoverning colonies, that liberation from the control of the Imperial Parliament is a condition of their adhesion to the Empire, has been followed by much discussion of schemes having for their purpose the establishment of some form of Imperial Council or Senate, to deal with the relations of the self-governing colonies to each other, to the United Kingdom, 
and to foreign States. As a means towards this end, there has been proposed a development of the Imperial Conference by providing that a Prime Minister, not necessarily the Prime Minister of the United Kingdom, should preside at its meetings, and that the business of the Conference should be transferred from the Colonial Office to an Imperial Secretariat. A step in this direction has already been taken by creating, within the Colonial Office, a separate branch of the Establishment, called the Dominions Department, to deal with the affairs of the self-governing colonies.

At a meeting of the Royal Colonial Institute in June, I908, Lord Milner read a suggestive paper under the title of The Two Empires, grouping in one Empire the self-governing colonies, and in the other, which he called the dependent Empire, India and the Crown colonies. He called attention to the advantages which must accrue to each of these Empires from friendly relations and interchange of their natural resources; but, at the same time, he indicated the formidable dangers that threatened each, and menaced the very existence of the British Empire as a whole, from the conflicting interests arising out of their racial distribution. This was before the passing of the Union of South Africa Act.

After the passing of the Act the position it created was discussed at a meeting of the Colonial Institute on April I 2 th last, when a paper was read by Sir Gilbert Parker on The New Empire, meaning by the phrase the association of Dominions which came into full life with the accomplishment 
of the Union of South Africa. In the course of the discussion, it was inevitable that attention should be called to the bearing of the Union, with its corollary propositions, on India and the Crown colonies. The point was raised by Mr. Geoffrey Drage: "Both here (he said) and in the great self-governing colonies, we have to recollect it is not only ourselves or the great sister States or India which are concerned in negotiations, whether affecting trade or other great interests. There are vast possessions, teeming with populations little known and understood, which go technically under the name of the Crown Colonies and Places. If we are to retain and advance this Empire of ours as a whole, we must consider whether in these Crown Colonies and Places, where we alone represent to the natives a chance of anything like tolerable existence, we do our duty. There are those who are apt to think-I say this with the greatest respect-that their work in developing Canada or Australia is the whole expected of British subjects. But there is also the white man's burden. There is the vast burden of administration of our coloured fellow-subjects, a burden which is increasing year by year and day by day, and which is making greater and greater demands upon us. That is a point which must never be forgotten."

More recently, on June 7 th last, Lord Milner made the Crown colonies the subject of an address to the Liverpool Chamber of Commerce, a body whose members have for many years been associated with every movement having for its object the economic development of the territories grouped under 
their denomination. Lord Milner drew attention to their practically unlimited resources and possibilities; to the fact that their products are complementary to the products of other constituent parts of the Empire, and from an economic point of view indispensable to the conditions of a self-supplying and self-contained Empire. Passing from the development of the resources of the Crown colonies as a business proposition, he insisted on their importance as a field for the exercise of political capacities. "Nothing," he declared, "strikes me more constantly in what I may call the misdirection of natural energy than the extraordinary contrast between the amount of time, and labour and ingenuity, and, I may add, temper, which is expended on the least of our home political questions compared with the plentiful lack of thought and energy devoted to even the biggest problems of Empire, and especially the biggest problems of our Crown colonies," and he proceeded to urge the importance of a thorough study of the administration of our tropical dependencies-our Crown Colonies and Places. To this study my work is a contribution, and I can only hope that it may serve to quicken a conception of our Crown colonies, " not as isolated and unimportant adjuncts of our Imperial heritage, but as destined to play a very essential part in its development as a whole." It may serve at the same time to show that the period which has secured the complete liberties of our self-governing colonies has, in Lord Milner's words, been marked "by a change for the better in regard to the Crown colonies and a more progressive and liberal policy."

All the problems discussed in this work have been 
dealt with as factors of the general problem of adapting to every constituent part of the Empire the principles that underlie the British constitution. Every administrative act is the product of three factors, principle, policy and practice. By principles I mean the fundamental laws of government accepted by a State as in accordance with the ordinances of nature and the will of God ; by policy the application of these principles to the circumstances and environment of communities; by practice the expedients of individuals to meet particular cases. In the Crown colonies, principle is determined by Parliament as interpreter of the spirit of the British Constitution; policy by the Colonial Office subject to the control of Parliament ; practice by the Governor subject to the control of the Colonial Office.

Canning declared that the British Constitution was the plunder accumulated by British subjects in many victories over their kings. In a sense not contemplated by Canning, the accumulation was substantially enriched by the victories of the British subjects of the North American colonies who, by revolt and secession, added permanently to the experiences of the world, assigned a new course to history, and determined the principles which have been accepted as the fundamental law of the British Constitution. Nowhere, and at no time, has its spirit been better expressed than by Alexander Hamilton in The Federalist, in discussing a system of government to be established on the basis of the Declaration of Independence:

"The sacred rights of mankind are not to be rummaged for among old parchments or musty 
records. They are written, as with a sunbeam, in the whole volume of human nature, by the hand of the Divinity itself, and can never be erased or obscured by mortal power. I consider civil liberty, in a genuine, unadulterated sense, as the greatest of terrestrial blessings. I am convinced that the whole human race is entitled to it, and that it can be wrested from no part of them without the blackest and most aggravated guilt."

The principle underlying this declaration I accept as the only foundation upon which the superstructure of Empire can securely rest, and I embody it in the title of my work, The Broad Stone of Empire. This title is derived, as the student of Western civilisation will readily understand, from Kenelm Digby's work, The Broad Stone of Honour, and was suggested by his claim that the chivalry of the heroic age of Christendom might be compared to the rock of Ehrenbreitstein on the Rhine: "broad in respect to its principles and its law, latum mandatum tuum nimis; broad in acknowledging distinctly and broadly the eternal truths of religion, that all men are equal before God." The phrase might suffice to justify my choice of a title, but I find a fuller justification in the following narrative, recounted by the author as illustrating the policy of the great men of a great age, which I gladly incorporate in this preface.

"Werner I., Bishop of Strasburg, in the eleventh century, who deserves immortality for building the greatest part of that cathedral, wished to have a place of security against the power of the Emperor, so he wrote to his brother, Count Ratbot, who lived in the old family castle at Altenburg, and sent him 
a large sum of gold and silver, with directions to employ it in building a strong castle. Time passed, and the Emperor was far absent in Lombardy, and the reverend lord remembered that he, too, had worldly matters to look after, and that he ought to examine how Count Ratbot had fulfilled his directions; so with this design he ordered a troop of twenty-nine horsemen, and, taking with him his chaplain and his noble pages, he set off to ride up the Rhine with great speed. About twilight he entered Basel, and still he pushed on to Augst, where he rested and slept far into the next day, to the great joy of the pages, who were sadly knocked up with the hasty scouring of the country. The second day's journey, upon reaching the Bözberg, the Bishop pulled up, and, making a spyglass of his hand, for he was not clear-sighted, asked aloud whether anyone could see the new castle. 'Can it be that miserable crow's nest yonder, where I expected to find a noble eagle's eyry?' This was all that passed, and they rode on till about evensong, when they reached the new Habsburg, so called to express its being a place of security for the family property. Ascending the hill, the good Bishop shook his head often, and kept muttering, 'no bulwark, no trench, not a wall to be seen': thus they reached the gate, which received the troop into the Count's castle. Here, again, the Bishop expressed his astonishment and displeasure, but the Count replied, 'My most reverend lord and brother, I have endeavoured to the best of my power to fulfil your will, and that your grace will perceive by to-morrow morning, when I shall 
have raised two other walls round the castle, and then you will find that I have well employed your gold and silver.' The Bishop, who ever had the fear of God before his eyes, was struck to the heart by these words, as if by a dagger. 'Alas, and woe is me,' said he ; 'has my unlucky brother made a league with Satan that he can perform such a work by to-morrow morning!' So with silent nods of the head the Bishop took leave for the night, and withdrew to his bedroom, where he lay in much trouble, till, exhausted with great fatigue, he at length fell asleep. And now, at the crowing of the cock, as he lay peaceably, and two noble pages watched before the bed, lo, the whole castle suddenly resounded with such a crash of horns and trumpets that the Bishop in terror jumped from his bed, and, throwing his robe round him, hurried to the battlements, whence he could see the surrounding country; but no words could describe his countenance when he saw two lines of warlike troops, infantry and cavalry, fully armed, stand around the castle, who began another flourish of trumpets. 'O woe and gracious Heaven pity me!' cried the good Bishop; 'are these the two walls?' While yet speaking, the Count touched him on the shoulder, and bid him fear nothing, for these were brave men, who would ensure their house of refuge; 'for these,' he continued, 'are all our people, ready to do us honourable service, and this is better than stone walls, without hearts and arms to defend them.' The Bishop, full of joy, embraced his brother, and praised him in fair words, and the Count made the noble knights and warriors come 
up to the castle and do homage to the Bishop, and swear to serve their race for ever; and so these were the first counts of Habsburg. "These few words,' says Voght, 'convey the whole history of the House of Habsburg. Not by bulwarks and warlike armaments did it become great and powerful, but by the love and fidelity of its people.'"

It is idle to speculate on the course history might have followed had the policy of the House of Habsburg been consistently guided by the principle symbolised in this narrative. But the application of accepted principles of government to the policy and practice of administration has been the problem of ages. Lord Beaconsfield declared that in practical politics there is nothing more important than to distinguish between the excellence of a theory and its premature or inopportune application. The American philosopher, Emerson, expressed the same truth in declaring that history reveals nothing more remarkable than the facility with which a benefactor may become a malefactor merely by continuing his activity into an area where it is not due.

Lord Acton commenting, in his Essays on Liberty, on Alexander Hamilton's declaration, has observed that it was made at a time when Burke, in the fervour of early liberalism, proclaimed that a revolution was the only thing that could do the world any good: "Nothing less than a convulsion that will shake the globe to its centre can ever restore the European nations to that liberty by which they were once so much distinguished." The convulsion was not long delayed, and to restore the liberties of Europe the French Revolution decreed the immediate 
destruction of every barrier raised against them by class or creed. In Lord Acton's words, the Revolution "staked the existence of nations, sacrificed lives and fortunes, covered Europe with a lake of blood, shattered crowns and sceptres, and flung parliaments into the sea."

Continuing its activity into the area of the tropics, the Revolution decreed the abolition of slavery and the destruction of every barrier to social and civic equality raised by the prejudice of colour. Then the racial antipathies of colour generated by slavery broke out in a conflict which culminated in Hayti, exterminating the European community, destroying capital in every shape, and paralysing labour. During the long period of the Revolutionary wars that followed, England, who had for centuries staked her existence as a nation in defence of the principles of the Revolution, was driven to defend her existence against its methods. In the reaction against these methods the steady progress of the forces that had accomplished the Reformation and the Revolution of 1688 was arrested, and the consequences were revealed in the condition of the people at the close of the Revolutionary wars.

I have, in a chapter on our national policy during the period of peace that followed, endeavoured to give from contemporary sources a concise but graphic account of their condition. It has been summed up in a comprehensive phrase by $\mathrm{Mr}$. Benjamin Kidd in his work on Social Evolution: "They lived like brutes, huddled together in wretched dwellings, without education, and without any voice in the management of public affairs." 
I have then analysed the policy which, based on a recognition of the truth concentrated in Emerson's aphorism, substituted constitutional reforms for revolution, and removed the barriers of class and creed by expedients which, in striking contrast to the revolutionary methods described by Lord Acton, averted every danger that imperilled the existence of the nation and the lives and fortunes of the people, shed no blood, made crown and sceptre the emblems of liberty, and established Parliament on a foundation of rock. I have shown how the results of sanitation and education, and the ennobling influence of a share in the management of public affairs, brought about the conditions necessary to economic prosperity and political sobriety, and established, as a fundamental law of the constitution, the principle expressed in the formula that every citizen of the United Kingdom in the lowest social order is a potential member of the highest. In this part of my work I have laid under contribution a voluminous literature. If I have not rendered to all their due, I can only hope to disarm criticism by the frank admission: J'ai pris mon bien partout oit je l'ai trouvé.

In succeeding chapters I have discussed the extension of the principles of our national policy into our Colonial and Imperial policy, and have traced it up to the bifurcation of the ways that lead through the temperate zones and the tropics respectively. The bifurcation has led to well-defined positions. In the temperate zones, as we have seen, the adhesion of the self-governing colonies to the Empire is conditioned by their complete liberation 
from the control of the Parliament of the United Kingdom. In the tropics, the adhesion of the Crown colonies to the Empire is conditioned by the maintenance of that control, for on the efficiency of that control their existence as civilised communities depends.

The bifurcation was determined, as has been indicated, by the natural distinctions between the temperate zones and the tropics, in respect of their material resources and the characteristics of their populations. These characteristics are of infinite variety, but are subject to the general law that the conditions most favourable to the development of the temperate zones have been found in the white races, while the conditions most favourable to the efficiency of manual labour in the tropics are found only in the coloured races. On the other hand experience has shown that the profitable development of tropical resources, in such a fashion and to such an extent as to provide the revenues necessary to support a civilised government, is beyond the range of the classes of African and Asiatic descent which constitute the labouring population of our tropical colonies. The very existence of these colonies as civilised communities depends on capital and science of European origin.

Out of these conditions arise the threefold interests on the adjustment of which the success of Crown colony administration depends: the interest of the British taxpayer, of capital invested in the colonies, and of labour of African and Asiatic origin. The Colonial Office, as the representative of the interests of the British taxpayer, is responsible for the efficiency 
of the civil administration, the foreign relations and defence of the colony, because the British taxpayer is in the last resort responsible for the financial consequences which may result from failure in any of these departments of administration.

I have in two separate chapters discussed the constitution and functions of the Colonial Office, and traced the evolution of the office of its responsible agent, the Colonial governor. The method of exercise of the functions of the Colonial Office through the Governor is illustrated in the discussion of every problem included in my work. First in order of importance among these problems is the constitution of legislatures appropriate to the variety of stages of civilisation represented, not only in different colonies but in the population of each. The discussion of this problem is logically followed by a review of the systems of law in force in the colonies. They present a mosaic of systems of various origin, bewildering in their number and complexity, and I have dealt with the problem of revising the legal system of each by consolidation and codification, and at the same time introducing so much of uniformity and assimilation as may be possible without destroying the national individuality of each.

The chapters entitled "Labour" and "The Coloured Races" discuss a variety of questions subsidiary to the general problem of providing the colonies with an appropriate population. By this term I mean a population appropriate to its environment, adequate and not overcrowded. To secure such a population, by the transplantation of 
the redundant masses of overcrowded areas to areas where their services are urgently required, has long been recognised as one of the highest functions of civilisation in the Crown colonies, as it is getting to be more and more fully recognised in the self-governing colonies of the temperate zones.

But number is not the only factor in the problem of an adequate population. In proportion as experience has proved the economic value of our tropical colonies it has compelled us to realise the extent to which the agencies of development are dependent on the preservation of health against tropical diseases. I have exhibited the imperial aspects of the study of health in the tropics, traced the history of the organisation of agencies and methods to combat the diseases of men and animals, and given some account of the results secured. 'The discussion of these problems concludes my first volume.

In my second volume I discuss the problem of bringing the results of modern civilisation in the temperate zones to bear on the agencies of beneficial occupation in the tropics-political administration, industry, and commerce, and the final problem of securing life and property against foreign aggression.

British administration in the tropics is based on the proposition that there can in the long run be no permanent divorce between the masses that produce and the class that is to administer the revenues of a country ; in other words, that every immigrant must be a potential citizen. It is submitted, as a corollary 
proposition, that any educational system appropriate to the Crown colonies must be adequate to qualify the community, without distinction of race or creed, not only to take a share in the administrative activity of the civil government, but in the development of the productive powers of the soil, by the application of science to industrial processes, as well as in every branch of commerce concerned with the distribution of colonial produce.

The discussion of an educational policy based on this principle is inseparable from a consideration of the problem of making religious liberty auxiliary to the purposes of the State and a link in the chain of forces that secure the adhesion of the Crown colonies to the Empire.

The discussion of agencies of intellectual and ethical development leads logically to a discussion of the economic development of the Crown colonies by scientific systems of agriculture and forestry. And just as the very term "colonies" implies an immigrant or transplanted population, whether of European or non-European origin, so a main factor in tropical agriculture and forestry is the transplantation of products from regions of origin in one part of the globe to others of appropriate climate and soil. In the chapter I have devoted to these subjects I have traced the development of scientific methods through the agency of the Royal Botanic Gardens, Kew, and the general extension of the agency by a system of colonial botanic gardens.

As the development of the resources of the tropics as a market of supply would be profitless without adequate markets of demand, I have 
devoted a chapter to the history and operations of the Imperial Institute as a centre of intelligence, in respect, on the one hand, of the possibilities of production of the British Empire ascertained by scientific research and developed by scientific methods, and, on the other, of the range of requirements not only of the British Empire, but of the whole world. The Imperial Institute is a centre of operations in which the geographical societies of the United Kingdom and other associations are collaborating. The common aim may be described as an inventory of the vegetable and mineral resources of the Empire. The subject is now engaging much attention, and the name of "regional geography" has been given to what constitutes a new department of scientific study. It may be defined as the study of the physical and biological phenomena of areas in relation to their natural facilities of access to profitable markets.

The work of the Imperial Institute has succeeded in convincing capital and commerce of the intimate connection between scientific research and industrial prosperity, but the practical application of the results of the Institute's work, as a centre for the study of regional geography, depends on the investment of capital, and facilities of transport and communication between the markets of supply and demand. The capital invested in the development of the Crown colonies by facilities of transport is derived from two sources-funds raised by colonial governments by loans on the security of the general revenues for expenditure on public works, and funds provided by private enterprise on the security of their under- 
takings. There is, of course, an intimate connection between the security of the capital in the one case and the other; and as the United Kingdom is in each case the centre of supply, the financial requirements of the colonies have come to be focussed in the office known as the Crown Agents' Office. I have given an account of the origin and transactions of the office, and have illustrated the results of the system in the extension of facilities of transport in different colonies. The expansion of the Crown colonies in equatorial Africa has, during the last few years, given constantly increasing importance to the office and its operations as an agency for encouraging the investment of British capital in British Crown colonies.

Intimately connected with the security of investments in our Crown colonies, in view of the magnitude of their sea-borne commerce, is the security of navigation from the perils of the seas, and, in particular, in tropical seas, security from cyclonic disturbances. I have therefore devoted a short chapter to problems connected with the law of storms, and illustrated the importance to the Crown colonies of an organised imperial system of meteorological, magnetic, and seismometric observations.

The value of such a system depends on an organised imperial system of telegraphic communication, and therefore my chapters on transport and meteorology are followed by a chapter on imperial communication by post and telegraph. The assistance of Mr. Henniker Heaton has enabled me to give, so far as the limits of space have allowed, a fairly full and, I believe, accurate account of the 
evolution of the penny postage system and the corollary proposition of a penny-a-word telegram system. In the threefold bearings of cheap communication on social relations, commerce, and defence there are no constituent parts of the Empire more interested than the Crown colonies.

As the British taxpayer is in the last resort responsible for the financial condition of the Crown colonies, and as their financial condition depends on the development of their resources, while the development of their resources depends almost exclusively on the investment of British capital, the problem of appropriate fiscal systems is evidently of the first importance. If I have assigned it a place towards the close of my work, it is because the financial condition of the Crown colonies is the result of the working of all the problems that have led up to it.

Under the head of Expansion I have devoted a chapter to an illustration of the practical bearing of the various problems discussed in my work in the development of the colony of British Guiana. From the days of the imperial adventurers of the sixteenth century, British enterprise has been prompted by the spirit of romance and the genius of commerce to exploit the reputed wealth of this territory, and yet, while modern discovery has proved that its real wealth exceeds the fables of romance, the area exploited was up to the period dealt with in my narrative limited to a fringe of land on the seacoast and on the borders of two or three of its rivers. The colony affords a typical illustration of the resources of our colonies concentrated in a compact area. 
The following chapter of my work is devoted to the problems of defence, and needs no introductory comment. It leads naturally to a consideration of the Crown as an outward and visible symbol of a power that enables diversities and even contradictions to exist in constituent parts without destroying the unity of the Empire.

In different chapters of my work I have expressed my obligation to many distinguished authorities who have assisted me with their counsel and advice. It remains for me to acknowledge the help I have received from other sources. Mr. C. Atchley, Librarian of the Colonial Office, has given me facilities for consulting records and documents in his keeping for which I am grateful. The Royal Colonial Institute has been generous in placing its valuable library at my disposal, allowing me to take out for quiet reference at home every volume I have asked for. To the Institute $I$ am also indebted for permission to reproduce the map of British Guiana prepared for the use of the tribunal constituted by treaty in 1897 to determine the boundary between British and Venezuelan territory. For permission to reproduce the map showing the area of British territory in the tropics presented to the London School of Medicine by Dr. Osler, Regius Professor of Medicine at the University of Oxford, I am indebted to the School; while the Director, Dr. C. W. Daniels, has not only supplied me with a summary of the results accomplished, but he has been good enough to look over the proof-sheets of two chapters of my work. To the authorities 
at Kew I am especially indebted; Sir William Thiselton-Dyer and Lieut.-Colonel Prain have given me material assistance, while Mr. Aikman has supplied me with a mass of official documents and records, on which my chapters on Agriculture and Forestry are largely based. He has also revised my proof-sheets. To Mr. T. F. Claxton, Director of the Royal Alfred Observatory in Mauritius, I am indebted for an account of the origin and progress of that institution included in my chapter on Meteorology. The laborious work of constructing the Index has been undertaken by Miss J. J. Elliot, who has rendered me valuable help in other ways.

To Sir Clement Kinloch-Cooke I am indebted for permission to reproduce the substance of many articles that have appeared in The Empire Review. The Editors of the British Medical Journal and of the Journal of the Royal Ammy Medical Corps I have to thank for their courtesy in publishing addresses delivered to the London School of Tropical Medicine and to the Medical School of St. Thomas' Hospital, and for permission to reproduce the substance of my addresses in my chapters on Health.

To Mr. Mowbray Morris I desire to express my cordial thanks for his kindness in looking over the proof-sheets of the whole work, and for the advice his long experience has suggested.

CHARLES BRUCE, 


\section{CHAPTER I}

\section{THE CROIVN COLONIES}

ThE British Empire occupies more than one-fifth of the territorial surface of the globe, including every climate of the temperate and tropical zones, and capable of producing every article of food and material for manufacture that can satisfy the needs of the human race. The problem of the century is the development of the resources of each constituent part of the Empire in such a way that it may be auxiliary to the prosperity and progress of every other part. Subsidiary to this is the problem of finding in these vast territories an appropriate place and appropriate work for every British subject.

The Statistical Abstracts of the Board of Trade classify the component parts of the Empire under the heads of United Kingdom, British India (including the Native States), and Colonies and Possessions. The British Isles of the United Kingdom cover an area of a little over 1 20,000 square miles, with a population of over $44,000,000$ persons deriving their food supply, and the raw materials of manufacture on which the earnings and the purchasing powers of the vast majority depend, from imperial and foreign sources. The approximate area of 
British India is $\mathrm{I}, 800,000$ square miles with a population of nearly $300,000,000$ inhabitants. Exclusive of the United Kingdom and India, our colonies are estimated to extend over about 9,500,000 square miles, a territorial area exceeding the Dominion of all the Russias, more than twice as great as the Republic of France and her colonies, nearly eight times as large as the Empire and colonies of Germany, three times the area of the United States of America, with their recent extra-territorial acquisitions, and more than twice as large as the united area of the Empires of China and Japan. Of the total area of 9,500,000 square miles, nearly $7,500,000$ lie in the temperate zones, and fall within the domain of the self-governing colonies, namely, of the Dominion of Canada and Newfoundland, the Commonwealth of Australia, the Dominion of New Zealand, and the Union of South Africa. The vast areas of these colonies are sufficient to supply the United Kingdom with every product of the temperate zone in the way of food and raw material; and, as they number less than $19,000,000$ inhabitants, it is impossible to exaggerate their importance as agencies for the re-adjustment of the congested population of the urban areas of the United Kingdom.

The editors of the Colonial Office List have been good enough to supply me with a statement from which I have compiled a table of general statistics showing the geographical distribution, the area, population, revenue and expenditure, public debt and trade of all colonies, colonial dependencies, and protectorates more or less directly under the 
control of the Home Government. ${ }^{1}$ In this work dependencies and protectorates are included in the term Crown colonies. The term includes places held for military or naval uses such as Gibraltar and Malta, or as centres of trade such as Hong Kong; but I shall limit myself mainly to problems of administration arising out of the use of our Crown colonies as areas of tropical production.

The magnitude of these interests and responsibilities is shown approximately in the following summary.

\begin{tabular}{|c|c|c|}
\hline & $\mathrm{I}, 860,0$ \\
\hline \multicolumn{2}{|c|}{ Population (estimated) } & $3^{8,020,0}$ \\
\hline Revenue - & - & - \\
\hline Expenditure & - & - \\
\hline Public Debt & & - \\
\hline mports & - & \\
\hline xports & - & $3^{8}$, \\
\hline
\end{tabular}

It is remarkable how many great staples of the world really come, not from the temperate regions, but from the tropics. They may be considered under four heads :-

I. Agricultural resources.

2. Forest resources.

3. Mineral resources.

4. Power resources.

The expansion of England in the tropics has passed through three stages, - a period of seeking after gold and other treasure, a period of enterprise for the purpose of trade with natives, mainly in

${ }^{1}$ See Appendix I. 


\section{THE BROAD STONE OF EMPIRE}

spices and groceries, and a period of development of local resources by British enterprise under British control. Throughout the two earlier periods, and in the later period up to the time of the abolition of slavery in British possessions, the profits of enterprise in the tropics were confined almost exclusively to the capitalist. So long as practically all the operations of production and local transport were performed by slave-labour, cost was a matter of secondary consideration, and the area of local activity had no place for the British workman. But with the abolition of slavery, and other economic changes, the cost of labour in production and local transport threatened to make the development of tropical resources unprofitable. The result of the changed conditions has been to substitute to a very large extent for the natural agencies of sunshine, manual labour, and animal draught, the modern agencies of chemistry and machinery. In this way there has been opened to the British workman a vast area of activity in which he shares with the capitalist the profits of the development of tropical resources.

The agricultural and forest resources of the tropics divide themselves generally into two classes; articles that enter into the primary and constant consumption of every family in the United Kingdom; and raw materials for manufacture, upon an adequate and constant supply of which more than $20,000,000$ of the wage-earning inhabitants of these islands depend for the means of existence.

To the former class belong, among many other products, sugar, tea, coffee, cocoa, spices, rice, 
tapioca, bananas and citrus fruits, and tobacco; while the latter includes cotton, rubber, fibres, and oils. The mere enumeration suggests the vast importance of agriculture and forestry in the tropics, and of the development of our tropical estates; but to realize it we must consider the multitude of interests associated with the production of these commodities.

Among articles of diet sugar holds the first place, not only on account of its universal use, but by reason of the many subsidiary agencies and interests dependent on its cultivation, manufacture, and distribution. Alike in the field and in the factory all the secrets that science has wrested from nature have been applied to the production of sugar. The importance of this industry was picturesquely described by Lord Beaconsfield: "Sugar has been embarrassing, if not fatal, to many Governments. Strange that a manufacture which charms infancy and soothes old age should so frequently occasion political disaster." And again: "Singular article of produce! What is the reason of this influence? Is it that all considerations mingle in it; not merely commercial, but imperial, philanthropic, religious; confounding and crossing each other, and confusing the legislature and the nation, lost in a maze of intersecting and contending emotions?" 1 The words are still applicable to sugar, but with the development of the tropics they have gained a wider significance. Considerations not merely commercial, but imperial, philanthropic, and religious underlie the whole range of tropical

${ }^{1}$ Lord George Bentinck: a political biography. Eighth edition, I872; pp. 232, 380 . 
resources and the rivalry of nations for the control of the regions which produce them.

The commercial interests associated in the tropical sugar-industry did not fail to be recognised by such foreign governments as, being without adequate tropical possessions, were unable to participate in the profits of cane-sugar. They determined therefore, as a substitute, to promote the cultivation of beet-root-sugar in their own temperate regions. Being confronted, however, by the difficulty of competing against an article which could be produced more cheaply than the proposed substitute, they decided to adopt a system well known in the sphere of commercial competition, and to destroy the rival industry by a system of bounties which enabled their sugar to be placed on the market at a price below the lowest possible cost of production of either sugar.

The consequences of this rivalry, within fifty years of the incidents that suggested Lord Beaconsfield's picturesque rhetoric, were summed up in 1907 by Mr. W. G. Freeman and Dr. S. E. Chandler in their exhaustive work The World's Commercial Products.

Commercial Sugar-Crop of the World.

Cane-Sugar.

Present Day.

4,000,000 tons, 40 per cent.

Fifty Years Ago.

I,250,000 tons, 84 per cent.
Beet-Sugar.

Present Day.

6,000,000 tons, 60 per cent.

Fifty Years Ago.

250,000 tons, 16 per cent.

The quantity of sugar coming into commerce annually had thus risen from $\mathrm{I}, 500,000$ tons to 
approximately $10,000,000$ tons of an estimated value of $£ \mathrm{I} S 0,000,000$. This does not include the canesugar used for local consumption in India and the East generally, in South America, in Africa, and elsewhere. The amount produced for local consumption in India is estimated at 3,000,000 tons. With the increase of production there has been increasing in constantly progressive ratio the importance of the allied subsidiary interests.

The extraordinary development of the beet-sugar industry was mainly due to the application of science to the joint work of the botanist, the chemist, the engineer, and the manufacturer. The exigencies of competition have now associated the same agencies with the cane-sugar industry. To the botanist is due the discovery that sugar-canes, contrary to what had been previously thought, bear seed, and the discovery has opened a wide field of activity in raising new races of superior quality. To the chemist and chemical manufacturer falls a great economic work, the analysis of soils and the investigation of manurial requirements. The science and skill of the engineer are invoked at every step. In British Guiana and in the Straits Settlements elaborate systems of irrigation are a condition of cultivation; in nearly every colony the cane is carried to the mill by mechanical draught; in the mill the engineer and the chemist are associated. It is beyond the scope of my purpose to give a detailed account of the operations of the mill, but I borrow a concise summary from a useful little work on Agriculture in the Tropics by Mr. J. C. Willis, in the Cambridge Biological Series. And I may observe that the publication of this book 


\section{THE BROAD STONE OF EMPIRE}

by the University of Cambridge is of itself an evidence of the national importance attached to the subject.

"Once in the factory the sugar-cane goes through a variety of processes. It is first passed through large and heavy rollers, which crush out the juice. As a rule, it goes successively through two or three sets of such rollers. The refuse cane, known as megass, is commonly used as fuel for the engines in the factory and is carried to them by elevators. The juice is next clarified, by being mixed with unslaked lime, and heating, when the acids are neutralised, and the twigs and other débris contained in the juice rise to the top and are skimmed off. It is then concentrated by heating in several successive boilers, usually under lower and lower pressure, and finally the thick pasty mass is poured out to stiffen into sugar and then arranged in such a way as to allow the uncrystallisable 'molasses' to drain off."

All these processes are carried out by elaborate and costly systems of machinery constantly improved by scientific methods adapted to reduce the cost of production. There is no tropical industry in which specialisation in the details of manufacture, with this end in view, has gone so far, and in which factories containing the very best and latest machinery are so much required. But it would be impossible, without an elaborate system of diagrams such as have lately been published in the West India Committee's Circular, to give an adequate idea of a complete factory equipment.

The operations of the mill, again, call in further subsidiary interests associated with the by-products 
of cane-sugar manufacture, the megass or crushed cane-stalks left by the mill, molasses, and rum. Megass is used as fuel in specially constructed furnaces, and from the finer parts a cattle-food is prepared known as molascuit. Molasses is a good food-stuff, largely used in confectionery, but chiefly valuable as yielding the by-product, rum, and associating the sugar industry with the interests of distillery, and of a special branch of mechanical engineering.

The manufacture of sugar and the by-products of the sugar-cane completed, a new series of subsidiary interests is engaged in distribution. They include shippers, railway companies, merchants, retail dealers, bankers, stock-brokers, insurance companies, and lawyers.

A principal consequence of the system has been a tendency to separate the labour of cultivation from the work of the factory. Colossal factories are now largely supplied by small cultivators, who grow canes on their own account and send them to central mills to be manufactured into sugar. In this way there grows up gradually an important community of peasant proprietors, who supplement the profits derived from the sugar-cane by the cultivation of food supplies or by engaging in industries subsidiary to the work of the factories. A portion of this community is of course drawn off to supply the manual labour of the factory, and is trained to the work of the skilled artisan. By this process the native community are educated to avail themselves of every opportunity of advancement open to the industrial class of British origin. In short, the larger the 
opportunity for British capital, the larger is the opportunity for the native community.

With variety of degree and detail what has been said of sugar applies to tea. I take the following summary of production and consumption from The World's Commercial Products.

"At the present time, the average annual export of tea from the countries producing it, irrespective of the amount consumed in the countries themselves, amounts to about $\mathrm{I}, \mathrm{IO} 8,8_{2} 8,000 \mathrm{lbs}$. of a value of over $E_{\mathrm{I}} 6,000,000$ sterling. Of this huge total, the British Empire is responsible for nearly 350,000,000 lbs., worth no less than $£ 9,2$ I 7,000, or considerably more than half the value of the world's total production. India heads the list with a total export of the value of $\mathcal{E}_{5}, S_{30}, 000$, followed by that of China, valued at $£ 5,500,000$. In spite of this order of precedence, however, it should be noted that the actual quantity of tea exported from China is vastly in excess of that from India, being more than three times as much, but the quality of the product is very inferior compared with the Indian article, and hence the difference in value. Third in the list comes Ceylon with I 50,000,000 lbs. worth nearly $£_{33} 390,000$, followed at a long distance by Japan with $59,000,000$ lbs. valued at $£_{541,000,}$ Java with $18,600,000$ lbs., valued at $£ 395$,000, Formosa with i $8,000,000$ lbs., valued at $\mathcal{E}^{2}$ I I,, 00 , and Natal and the Caucasus with comparatively trifling amounts.

"So much, then, for the principal producing countries. When we turn our attention to the countries and peoples who consume this enormous quantity of beverage-making material, we find that 
heading the list as the greatest tea importers of the world are the people of the United Kingdom. During the last few years the annual import of tea from all sources into this country has averaged no less than 255, I I 2,000 lbs., costing us $£ 8,68_{3}$,000. We are followed by Russia, which annually receives about I 26,000,000 lbs., the United States with 8 I,389,000 lbs., followed by Holland, Australia, Canada, Germany and New Zealand with much smaller amounts.

"To us, as English people, a most important question in connection with the world's tea industry is, to what extent is the British-grown article displacing from the world's market the product of our only serious rival, China? Let us consider the state of affairs in some of the chief consuming countries. In the United States and Canada the taste for British-grown teas appears to have taken a firm hold. The quantity sent direct from Calcutta to Canada in 1904 was thirty-five per cent. higher than in 1903. Further, black teas from China have practically disappeared from the Canadian market, and in all probability the green teas from Japan, which at present are very popular in America, will follow them in a few years; for since Ceylon green tea was introduced in 1899 , the imports from Japan have decreased from I I, 000,000 lbs. to 4,000,000 lbs."

The origin and progress of the tea industry in Ceylon furnish an interesting record of the courage, industry, and intelligence of the planting community. The Blue Book for 1878 gave the export of tea as a little more than 3,000 lbs. In I 880 the area under 


\section{I2 THE BROAD STONE OF EMPIRE}

tea-cultivation was 10,000 acres, and the produce about 160,000 lbs. In I 890 about 220,000 acres were planted with tea and yielded about i 50,000,000 lbs. In I 908 about 390,000 acres of tea-plantation yielded over $180,000,000$ lbs.

As in the case of sugar, the cultivation of the tea-plant is performed by native labour, the plucking of the young shoots mostly by women and children; the preparation of the leaf for the market is done by factory work.

The preparation of the leaf includes four stages, withering, rolling, fermentation, and firing. Formerly all these processes were carried on by the natural agencies of manual labour, air, and sunshine. But at present the entire range of manufacturing operations is carried on by numerous forms of machinery and mechanical devices, and the preparation of tea has become a factory industry.

The first process is withering. The leaf is spread on trays exposed to a free current of air, until it becomes tough and flaccid like an old kid glove, the natural current being assisted by fans. The next process is rolling, the object of which is to mix the juices and to curl the leaf. The old Chinese system was to roll by hand to and fro, or by the dirty process of treading; but the operation is now performed by a variety of machines. The leaf is rolled between two hard wood or granite plates, worked by cranks which give them a compound circular or eccentric motion. A sieve is sometimes attached to the roller, and the leaf too large to pass through the mesh is re-rolled. The rolled leaf is then packed in drawers until it ferments, which forms the third 
process and makes the difference between black and green tea, the latter being unfermented. The last process is drying. This was originally done by firing the rolled or fermented leaf in iron-gauze trays over open furnaces; it is now effected by machinery. These processes complete the manufacture; but the final work of sifting the different qualities and packing the assorted tea is now also done by machinery.

While speaking of the association of European with native labour in developing the agricultural resources of the tropics, it is interesting to note the effect of this association in Ceylon. Mr. Willis, Director of the Royal Botanic Gardens in that island, has observed that the exports of European produce are to those of native produce as three to one, while the area of cultivation of the former, and the population supported by it, are only as one to five, the population being equally dense in either case, or denser on the European estates. The European produce is obtained by association; native produce by purely native industry and methods.

It is not my purpose in this chapter to prove the commercial interest of the United Kingdom in our tropical colonies by details of cultivation, manufacture, and distribution in respect of even the principal articles of tropical production that enter into the consumption of British households, or supply British industry with the raw materials of manufacture. I must limit myself to typical illustrations. To what has been said about sugar and tea I will add only a few words about cocoa. A 


\section{I4 THE BROAD STONE OF EMPIRE}

modern writer on commercial products of the vegetable kingdom, Mr. O. L. Symonds, declares that, "Cocoa is of modern drinks the most alimentary: it is without exception the cheapest food that we can conceive of, as it may be literally termed meat and drink, and were our half-starved artizans to drink it, instead of the innutritious beverage called tea, its nutritive qualities would soon develop themselves in their improved looks and more robust condition."

That the use of cocoa in the United Kingdom is steadily increasing is proved by the following figures, showing the quantities cleared for home consumption for quinquennial periods :

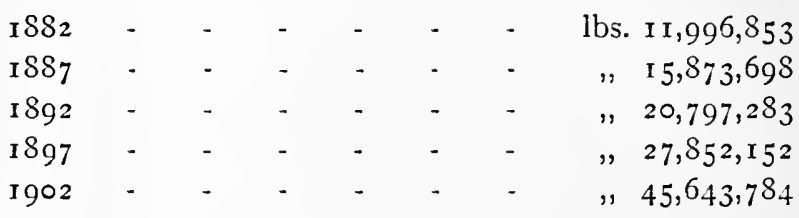

Since 1902 the world's harvest and consumption have increased by nearly thirty per cent.-from I I 5,000 tons to 165,000 tons-and the increase has been to the mutual advantage of the United Kingdom and of our tropical colonies. For in the preparation of the cocoa and chocolate of commerce the British workman is closely associated with the processes of manufacture at every stage. The imported cocoa bean is in fact only the raw material of manufacture. The chief stages of preparation are sorting and cleaning the raw beans, roasting the cleaned beans, breaking and shelling the roasted beans, grinding and adding sugar, spices, etc., moulding and packing. All these 
processes are carried on by elaborate machinery, constantly altered and improved. Nor is this the only advantage our workmen gain from the increase in the use of cocoa. Together with tea and coffee, it is one, perhaps the foremost, in a trinity of forces of tropical origin which help to redeem our national life from the curse of drunkenness. Our national drink-bill amounts to nearly $£$ I $70,000,000$ a year, and represents a consumption of absolute alcohol per head more than twice as large as the consumption of any of the countries competing with us for the control of the tropics. Many millions of this expenditure might be appropriated to the use of non-alcoholic beverages, largely the produce of the tropics, with equal advantage to the happiness of our people and the prosperity of those regions.

Rice is one of the most ancient and one of the most extensive cultivations in the world, no less than a third of the human race being estimated to live on that vegetable. It would be difficult to exaggerate its importance in determining the value of the tropics to the temperate zones, from its being a main factor in determining the cost of production of a wide range of tropical commodities. I have shown, in speaking of sugar, that the larger the opportunity for British capital, the larger is the opportunity for the native community. Of course the measure of opportunity for British capital is limited by the cost of production, not only in the case of sugar, but in every branch of industry. It is only the low wage-rate of tropical areas that enables them to supply at a price within the range of every family in the United Kingdom such articles 
of constant consumption as sugar, tea, coffee, and cocoa. And it is only the same low wage-rate that enables raw materials of tropical origin to be imported on terms which permit of the manufactured article being turned out at a price which ensures a large market, and yet allows an adequate wage to the British workman.

During the war between Russia and Japan attention was drawn to the fact that the inhabitants of the latter country live almost entirely on rice, and that this enabled their army to be catered for on conditions of extraordinary advantage alike in respect of cost and mobility. In the international conflict for the control of the tropics this is a factor of great importance.

Among commodities that largely add to the interchange of commerce between the temperate and the tropical zones tobacco must at least be mentioned. The world's annual production of tobacco amounts to upwards of $\mathrm{I}, 000,000$ tons with a value of nearly $£ 40,000,000$. It is not generally understood that, with the exception of the Russians, the British consume less tobacco per head than any of the principal peoples of the world, less than two pounds per head as compared with over five consumed by the United States, over three by Germany and over two by France. And yet the consumption of the United Kingdom averages considerably over 100,000,000 pounds per annum. There are few articles of tropical produce that offer our Crown colonies a larger area for expansion than tobacco.

In illustrating the extent to which the prosperity of this country depends on the import of raw materials 
of tropical origin, I may conñne myself mainly to cotton and rubber.

Few industrial movements have ever been started with more reason and intelligence than that promoted by the British Cotton Growing Association with the object of extending the cultivation of cotton in the British colonies, dependencies, and protectorates. In accordance with the general principles of our colonial policy in the nineteenth century we had been content to rely on the production of the Southern States of North America, which quickly displaced the use of cotton drawn from other sources in our manufactures, and reduced to comparatively trifling dimensions its cultivation in our tropical colonies. In the meantime, however, the world's demand for cotton had increased enormously, and the natural limitation of the Southern States, combined with speculative manœuvres in the manipulation of the supply, produced in the earlier months of 1904 a shortage entailing results equally disastrous to employers and operatives. It seems to be certain that under a proper system of organisation India and the British colonies can produce all the cotton required to afford the United Kingdom an adequate and stable supply. The national importance of the movement was shown in the prospectus of the Association in language which may be thought extravagant, but the substantial truth of which cannot be gainsaid. They say :

"It has been estimated that if all the cotton mills in this country were running three-quarters time instead of full time the loss would not be less than $£_{300,000}$ a week, or at the rate of $\ell_{15}, 000,000$ per 


\section{I8 THE BROAD STONE OF EMPIRE}

annum. A prolonged continuation of such a serious state of affairs cannot be contemplated with equanimity, and the cotton trade, in which it is estimated that $10,000,000$ of the population of this country are directly or indirectly interested, has serious lessons facing it which must sooner or later react on the prosperity of the whole of the country, and eventually on other parts of the Empire.

"The objects of the Association are those of national importance, closely affecting not only spinners, manufacturers, and operatives, or dyers, printers, bleachers, finishers, and other allied trades. Merchants, shippers, and distributors are suffering severely; engineers, chemical manufacturers, collieryowners, machine-makers, bankers, lawyers, stockbrokers, insurance companies, railway companies, and shipowners are affected by depression in the cotton trade. Owners of property, shopkeepers, brewers, provision merchants, farmers, and in fact all wholesale and retail dealers in every branch of trade, and all producers, are concerned in it directly or indirectly."

The Department of Agriculture has, within the last eight years, successfully established the cotton industry in the West Indies, with the result that the total area under cultivation has increased from 4,000 acres in 1902 to over 24,000 acres, while the estimated value of the crop had increased from under $£ 10,000$ in 1902 to about $£ 200,000$ in 1907.

But it is in Africa, especially in Nigeria, that the development of the cotton industry, under the direction of the Association, supported by the Imperial Government, has advanced with such 
success as to justify the hope that before long our tropical colonies will produce a large share of the cotton required for the supply of the United Kingdom. The British workman will then be safe from the disastrous consequences which followed the American Civil War of I 86 I-65, and more recently the manœuvres of American speculators.

And to our tropical colonies in Africa we may look with confidence not only for a constantly increasing supply, but for a constantly increasing demand. "It is estimated," says the United States Department of Agriculture, "that of the world's population of I, 500,000,000 about 500,000,000 regularly wear clothes, about 750,000,000, are partially clothed, and 250,000,000 habitually go almost naked, and that to clothe the entire population of the world would require $42,000,000$ bales of 500 pounds each. It therefore seems more than likely that the cotton industry will go on expanding until the whole of the inhabited earth is clothed with the product of its looms." It is certain that in America the Southern Cotton Association is straining every nerve to meet a constantly increasing demand, as a result not only of the constant raising of our standards of living and comfort, but as a result of the advance of civilisation among barbarous people.

The last report of the Association shows that they have been at work seven years, the first two years of which were merely preliminary. During this period they have produced a grand total of I I 7,000 bales, worth nearly $£ 2,000,000$, and the annual turnover is now about 40,000 bales, of the value of half a million sterling. The West Indies 
are now producing 6,000 bales of Sea Island cotton, Nyassaland 3,000 bales, Uganda 7,000 bales and West Africa I 3,000 bales, very similar in quality to middling American cotton. They have not yet fairly touched Rhodesia, but that country is now growing the very best substitute for Egyptian cotton that can be found in any part of the British Empire. The Association has proved they can produce cotton of a quality required by the Lancashire cotton spinners, for a result of their operations has been that Lancashire has increased her cotton spindles by about I0,000,000 (a quantity equal to more than all the cotton spindles in Germany at the present time), has invested in new spinning and weaving mills upwards of $£_{1} 5,000,000$, and has thus found fresh employment for close upon 60,000 work-people.

A chapter of this work will be devoted to the important questions connected with forestry. They must be studied for each colony separately, but from tables drawn up by Dr. Schlich in his manual on Forestry in the British Empire he has derived an instructive summary. In the latest edition of this work, he estimated that of the timber valued at $£ 26,540,000$ required annually by the United Kingdom, India and the colonies could only furnish timber valued at $£ 5,440,000$. Apart from timber, there are considerable imports of other forest produce. He estimated the value of wood pulp imported at about $\mathscr{E} 2,000,000$ and of india-rubber at about $£ 6,000,000$ annually. He observed that endeavours to develop more systematic management in many parts of the Empire have frequently 
failed, because the limited funds required for such measures were not forthcoming, or other interests prevailed over the dictates of a sound forest policy, while the enormous sum of money which goes every year out of the Empire is lost sight of.

In illustrating the value of the forest resources of the Crown colonies I shall confine myself mainly to rubber. I shall deal elsewhere with the rise and progress of the industry; for the present it can be hardly necessary to expatiate on its importance. The annual consumption is estimated at 65,000 tons, which, at an average price of four shillings a pound, represents an annual value of nearly $£_{30,000,000}$. It is entirely a tropical production, and both demand and supply are constantly increasing. The value that it has given to our tropical estates is conveniently illustrated in the case of Ceylon. In I 886 one package of rubber of an estimated value of twelve shillings was exported. In 1896 about 600 acres of land produced I 57 hundredweight valued at about $£ 500$. In 1906 the cultivation of about 100,000 acres yielded an export of 3,000 hundredweight of the value of $£ 70,000$. The present area of cultivation is nearly 200,000 acres. Coincidently with the development of the industry in Ceylon, there has been a much larger increase in the Malay States, which in 1908 exported $\mathrm{I}, 4 \mathrm{I} 3$ tons. Mr. John Ferguson, in a lecture on Ceylon read before the Royal Society of Arts in April 1909, estimated that in I9I 2 Ceylon may produce 3000, tons (worth at three shillings and sixpence per pound about $£ \mathrm{I}, \mathrm{I} 70,000$ ), the Malay States, 7,500 tons (worth nearly $£ 3,000,000)$, and all Southern Asia from 


\section{THE BROAD STONE OF EMPIRE}

I 2,000 to I 3,000 tons (worth over $£ 5,000,000$ ); since that date the probable produce of Southern Asia has been calculated at 16,000 tons. These estimates were prepared with careful elaboration as a guide to genuine investment based on the probable limits of expansion of supply and demand. But they have already ceased to be of practical value, because the development of the industry has stimulated competition along the whole belt of the tropics. In Mexico, Brazil and Bolivia, in Western and Eastern Africa and in Madagascar, in India and Java, in Queensland, Polynesia, and New Guinea, promoters of companies are requisitioning capital for the exploitation of areas fulfilling the necessary conditions of soil, climate, and cheap labour. The result of this movement has been to make the market for rubber shares one of the most striking features of business on the Stock Exchange. It may be as difficult to liberate genuine investment from the speculative manœuvres of the Stock Exchange in the case of rubber as it has proved in the case of cotton; but it may be asserted that before long rubber will rival cotton in the importance of the subsidiary interests dependent on it, and as a factor in animating the struggle of nations of temperate zones for the control of the tropics.

Of all forest resources the palm is most closely associated in European ideas with the tropics, and yet the commercial value of the palm is little realised.

Among the almost infinite uses of palm produce, I must limit myself to the produce of the coco-nut palm and the oil-palm. The coco-nut palm is one of the most useful and ornamental trees of the 
tropics. It has a roughly triangular fruit, which is familiar in this country in the form of a desiccated nut, with a very hard shell, containing an indigestible flesh and milk. The thick outer husk of the coconut is composed of densely packed fibres yielding the coir of commerce. Coir fibre is largely used as a rope and cordage material, on account of its power to resist the action of sea-water. The kernel, cut up and dried, is exported as copra, and yields the coco-nut oil of commerce. It is an export of enormous value, largely used as an illuminant, in the manufacture of candles and soap, and for many other purposes.

The produce of the oil palm is a principal export of West Africa. The fruit of this tree is a great cone containing many hundreds of nuts. The actual kernel is enclosed in a hard shell, but this shell is enclosed in a skin of about the consistency of that of a chestnut, and between this outer skin and the kernel there is a porous husk, or packing, saturated with oil. The oil from the husk is expressed locally by boiling and maceration; the oil from the kernels is never expressed in the country, but by crushing machinery in Europe. The former is used for railway grease, soap, candles, and in tin-plate working; the finer oil of the kernel is used for lubricating.

In the development of our tropical estates we have hardly touched the surface of their mineral resources. In illustration of their probable, or at least possible, capacities I may refer to the ascertained mineral wealth of three of our Crown colonies. Accident, rather than scientific survey, has within 


\section{THE BROAD STONE OF EMPIRE}

the last few years revealed the fabled wealth of British Guiana in gold and diamonds. It was the search for gold that originally led Sir Walter Raleigh to "that mighty, rich and beautiful Empire of Guiana"; but for centuries the search was abandoned, until in 1884 gold to the amount of 250 ounces was officially declared among the exports of the colony. At the close of 1906 very nearly 2,000,000 ounces had been exported, of the declared value of over $£ 7,250,000$. This renewal of enterprise was quickly followed by the discovery in 1890 of diamonds in considerable quantities, and in a few years about 740,000 stones of an estimated value of $£ 68$,000, were declared for export. I need hardly add that as yet vast districts remain untouched.

At the same time as the gold and diamond fields of British Guiana were being worked, the mineralogy of Trinidad was being studied. In a paper read before the Royal Colonial Institute by Mr. Cunningham Craig in 1906, the mineral capacities of Trinidad were thus described;

"Slowly accumulated deposits of more or less decayed vegetable matter are the origin of all the carbonaceous and bituminous minerals of Trinidad, and the particular mineral found in any locality depends merely upon the conditions the material has been subjected to since its accumulation. Thus, in many parts of the island seams of lignitic coal are found, associated with carbonaceous shales and beds full of fossil wood and leaves, while in other localities fossilised vegetable matter is entirely absent, but the strata are found to be saturated with petroleum. Coal or lignite, manjak, pitch and oil all 
have a common origin; their relations can, perhaps, be expressed most clearly by an analogy with a substance well known in the West Indies, namely sugar. Coal or lignite represents the finished product, the usine crystals; bituminous coals are the muscovado; manjak is the molasses, quite distinct in properties and occurrence from the coal,--run off, in fact, but derived from the same original source; liquid asphalt is the more refined syrup, and oil may be looked upon as the rum. Not that the oil has been distilled from the pitch or manjak, but that it represents the more volatile constituents of the material, while pitch or asphalt represents the less volatile."

This liquid asphalt, or coal-pitch, has already proved a source of permanent revenue to the colony. Mr. Craig estimated that we have in Trinidad an oil-field of at least 500 square miles, with possibilities of output which may well prove of importance not only to Trinidad but to the Empire.

The extraordinary value of the agricultural products of Ceylon is rivalled by its mineral resources. There are in the island nearly $\mathrm{I}, 700$ plumbago mines and pits, and, according to the Colonial Office List for 1909 , over 7,000 gem quarries and pits, yielding chiefly rubies, sapphires, and catseyes. A mineral survey is now being conducted by officers appointed by the Colonial Office, under the Supervision of the Director of the Imperial Institute; and I may mention, as an important result of this survey, the discovery of the new mineral called thorianite, from its containing seventy-five per cent. of thorium. This discovery is likely to be of great value to 
Ceylon, since thorium is largely employed in the manufacture of incandescent gas mantles, while additional interest attaches to it since the new mineral is strongly radio-active, and may prove to be a source of radium.

I may add that in its pearl fisheries Ceylon has an asset of exceptional value, but the produce of tropical seas is beyond the scope of my work.

Vast as seems the capacity of our Crown colonies for expansion in the domains of agricultural, forestry, and mineral resources, it seems probable that in their power resources they have an asset of even superior value.

The great falls and cataracts on the rivers of our tropical colonies are beginning to receive the attention of the electrical engineer, and will in time be utilised as sources of electrical energy. The Potaro river at the Kaieteur fall in British Guiana is from 350 to 400 feet in width, and falls vertically in one vast stream for a depth of about 750 feet, nearly five times the height of Niagara, continuing to descend in a series of cataracts. It is estimated that at the Kaieteur there is running to waste as much energy as is consumed in the cotton industry in Lancashire.

In Africa we find in the caves of Mount Elgon the homes of a vanished race, placed under overhanging rocks in such a way that the cascades which fall over them obscure the entrance. The question of utilising these waterfalls for the purpose of a higher civilisation has now come within the range of practical engineering, and the day may not be far distant when Mount Elgon, with its fertile soil and 
healthy climate, will become the seat of an industrial community who could generate electrical power sufficient to serve half the territory of Africa.

I have, I hope sufficiently, indicated the commercial interests that animate and exasperate the struggle of the Great Powers of the world for the control of the tropics. They have come to realise the extent to which modern civilisation rests on the resources of those regions, and to recognise that the principle underlying all trade,- that exchange of products between regions and peoples of different capacities tends to be mutually profitable-finds in commerce between our temperate and tropical zones its most natural expression. Every year confirms the certainty that this immense sphere of commercial activity will continue to expand, and that expansion will be followed by international rivalry on a vaster scale than we have hitherto had to contend against.

$\mathrm{Mr}$. Benjamin Kidd, in the course of a discussion following a paper I read at the Colonial Institute on the Crown Colonies in 1905, observed that it is a curious fact, which economists in this country have largely overlooked, but which, early in the middle of the nineteenth century, German colonisers clearly perceived, that so soon as we have worked out all rivalries between English, Germans, and others in temperate regions, the real rivalry in the world will be for the control of the tropics, - for the channels of trade between them and the temperate regions. In the future the great trade of the world will lie not so much between countries in the temperate as between those in the tropical regions. The international struggle for the control of the tropics 
is bringing home to us that our self-governing colonies in the temperate zones cannot constitute a self-sufficing and self-contained Empire. We are reminded that in the earlier stages of British expansion we attached a great deal more importance to our tropical possessions than to our North American colonies. Indeed, by the Treaty of Breda, in 1664, England acquired that territory of America now known as New York in exchange for our colony of Surinam, now known as Dutch Guiana; while after the conquest of Canada, during the negotiations which followed the Seven Years' War, the British Government was urgent to exchange Canada for the small island of Guadeloupe. We are now beginning to realise that India and our Crown colonies are as essential to the solidarity of the Empire as the self-governing colonies.

It is not my purpose to discuss the problems of administration in South Africa, but the question of the rights of Indians in the Union has been recognised by the Government of India as intimately connected with the question of the solidarity of the Empire. Sir Harry Johnston, in an article in The Nineteenth Century, in August, I909, discussing the rights of the coloured races in the Union, has this interesting passage :

"I would press this question merely on the plea of expediency, and not of sentiment. Even supposing during the next twenty years that the coloured electors of Cape Colony did elect a coloured man to represent them in the supreme Parliament of South Africa? Why should that be such an odious possibility to the future million and a half of white people 
in that sub-continent, wherein there is also a coloured -mainly negro-population of $7,000,000$ ? Surely it is not the 'Imperial' way of looking at the question, with such possibilities as may be dawning before the great South African Dominion? It seems to me a provincial, a narrow-minded point of view, such as one should not expect from prominent white politicians in the four great colonies of South Africa, who, besides knowing well the needs of their own immediate districts, ought to be well informed and deeply interested in the remainder of Africa. You cannot detach South Africa from the rest of Africa, for this fact, among others, that in all the territory between Tanganyika and the Cape of Good Hope, which is under the British flag, there is a negro population of nearly $7,000,000$, at least $6,500,000$ of which speak Bantu languages closely related to those of East, West and Equatorial Africa. The mission-educated natives of Uganda and of other parts of East Africa; of Nyasaland and of the Barotse country; of the Congo basin; of the great British West African possessions, have all got their attention turned to the present state of affairs in South Africa.

"Again, it seems to be assumed by the real Little Englanders, the people who will not observe and connote, that all these African peoples north of the Zambesi have no voice, no understanding, no means of making themselves agreeable or disagreeable to the Imperial idea. A large number of them, speak, read, and write English with fluency; they have their own newspapers; they are visiting England, and are being educated there in increasing numbers. 


\section{THE BROAD STONE OF EMPIRE}

In the West Indies as in West Africa the negroes are at present ardent Imperialists because they have found in the British Empire an immense relief from native conditions of anarchy and bloodshed, vast resources in capital, and an unfaltering spirit of justice which has, especially of late, made no distinctions of race and colour. These people and the still small class (proportionately) of educated men in India will observe with the greatest interest the course which will be taken by the British Government in regard to the protection of the interests of the 'coloured' people in South Africa, and their own views as to the advantages of belonging to the British Empire will inevitably be tempered by the results of such action."

Three decades of international conflict for the control of the tropics have brought into clear contrast the policy of the United Kingdom and the policy of all the other Continental Powers of Europe in the administration of tropical possessions. The policy of the Continental Powers has adhered to a principle we have long abandoned, that a tropical colony is a possession to be worked for the profit of the colonising Power. In their foreign relations they have adopted a policy of rigidly exclusive monopoly, surrounding their colonies with walls of laws and tariffs designed to exclude the interests of the rest of the world. In their local administration they have adopted a policy equally designed to subordinate colonial interests to the profit of their own industry and commerce. Our colonial policy of the Victorian era has been based on diametrically opposite principles. Our tropical colonies include 
vast territories acquired at various dates by conquest, cession, or settlement, of an infinite variety of climate, soil, and natural resources, inhabited by diverse races, and presenting every type of administrative problem. In our relations to these territories we abandoned the policy adhered to by the Continental Powers because we realised that we must either abandon the colonies or abandon the policy; and we adopted instead the policy of holding them in trust for their own benefit.

The essential principles of our national policy may be concisely stated. It demands a constitutional system constructed to secure the representation of three forms of capital,-landed property, accumulated personal property, and the property every man has in his own intelligence and labour. It demands at the same time that this system shall retain the power of the State in the hands of the more competent classes, while making those classes accessible to all. British policy demands, moreover, a system of laws enacted not for the benefit nor by the power of a governing class, but for the benefit and by the consent of the governed. It demands a religious system based on the principle of liberty and toleration, an educational system designed as an instrument of social equality in the area of intellectual capacity, and a system of sanitary laws to serve as an engine of social equality in the area of physical capacity. It demands a system of labour based on the principle that the relation of the employer to the workman shall be a relation of contract between two independent parties. In a word, the fundamental principle of British policy is 
the principle of equal opportunity without distinction of class or creed. And the result of this policy has been to associate land, capital, and labour into a trinity of forces united in one common purpose,- the development of the resources of the nation by the organisation and expansion of industry and commerce,-and in one common interest,security against internal disorder and foreign aggression.

It has been observed by Mr. Kidd, in his work on The Control of the Tropics, that, "If the Englishspeaking world is to face the duty which lies before it in the period upon which we have entered, if it is to raise the rivalry for the control of the tropics above the sordid level at which it has hitherto been carried on, it must be able to meet the subsequent verdict of history with a higher sense of responsibility and a clearer faith in the deep importance of the ideas and forces of which it is the representative, than is to be distinguished in its relations to the tropics either in the past or in the present." I venture to think that the verdict of history will recognise the high sense of responsibility which has in the past distinguished British administrators in the tropics and is animating them in the present. They have had and have a clear faith in the ideas and forces of the policy they have administered, a clear faith that the idea of equality of opportunity, which has proved a force to unite men of diverse classes and creeds in a common purpose and a common loyalty, does not lose its force when to diversity of class and creed is added diversity of race and colour. As the purpose of this work is to illustrate the 
extension of the national policy of Great Britain into a colonial and finally into an imperial policy, it will be convenient for me here to describe the method on which it proceeds. At the close of the period of the revolutionary wars terminated by the Treaty of Paris in I8I5, the leisure of peace gave opportunity to consider the social condition of the people. I shall give an account of it as described in contemporary documents, or in the writings of authors of contemporary experience. It presents a record almost incredible to the present generation, and even to those whose lives embrace a portion of the period during which it existed. I shall then examine its causes. They had their roots entangled in every field of human activity, and every cause raised a problem. I shall deal with those problems, and show how they were solved, each by an appropriate method, but all in accordance with the principles I have indicated.

The collective result was a national policy of which I have stated the essential principles. But it was strictly a national policy. It will appear in the course of my narrative that among the many causes that degraded the social, moral, and intellectual condition of the people, a chief contributory cause was the burden of expenditure incurred in the acquisition and support of our colonies. Not unreasonably, the leaders who organised a policy of reform for the promotion of national interests, believing our colonial possessions to be politically mischievous and commercially useless, declared that the nation would be much better off without them than with them. I shall deal at length with the 


\section{4 THE BROAD STONE OF EMPIRE}

causes of this belief, and trace the drift of our colonial policy towards national isolation, colonial segregation, and the surrender of British industry and commerce to cosmopolitan competition. My narrative will then have to trace the causes that led to a revision of this policy, and ended by substituting for it an imperial policy based on the creed that our colonies are a political and commercial necessity. The new policy demanded a review of the relations between the nation and its colonies, and we were thus brought face to face with the fact that every administrative unit of the Empire raised the same administrative questions, - questions of the form of constitutions; questions of the legislative, judicial, religious, and educational systems ; questions of the relation of classes, of capital and labour; questions of health and sanitation; questions of the organisation of industry and commerce; questions of finance ; questions of foreign relations and defence. The logical result of our decision was to adapt to every administrative unit of the Empire the principles that had worked out the political, social, and economic welfare of the British nation.

The decision had an important consequence. It led us, almost unconsciously at the time, to trace a line of demarcation between our colonies (in the stricter sense of the term) in the temperate zones and our possessions in the tropics. In the former, emigrants of European descent are able to form permanent homogeneous communities in climates favourable to their development in the same physical, ethical, and political conditions that produced the European. These colonies we have provided, or 
allowed to provide themselves with appropriate constitutions under the supremacy of the British Crown, and left them the fullest responsibility for solving their own administrative and social problems.

This demarcation brought us to a well defined position. We had made up our minds that the development of our tropical possessions was a necessity, and that such a development could only take place by a partnership between the white and coloured races. The body of my work will be devoted to illustrating the methods by which this partnership is conducted. They represent a variety of means to a unity of end. They represent stages of constitutional and social methods adapted to stages of civilisation.

Self-government after the model of our self-governing colonies seems to be at present the ideal of every administrative unit of the Empire. Let it be so; but let us also bear in mind that the justification of that type of government depends on conditions that it may take generations, perhaps centuries, to realise. Ohne Hast olne Rast (unhasting, unresting) must be our maxim ; our spirit a spirit of caution in every procedure which has a tendency to bring into collision the usages and prejudices of communities, a spirit giving time for the slow and silent operation of desired improvements, with a constant conviction that every attempt to accelerate the end will be attended with the danger of defeat.

And on one thing I would insist above all others. My long official career in the tropics has been guided by the belief that the salvation of the Empire depends on the determination of each of its con- 
stituent parts to recognise the doctrine of equal rights for every civilised man. But my conscience has been guarded by the conviction that in the constituent parts there is a diversity of circumstances that makes uniformity of political constitution impossible. In each administrative unit in the tropics it is necessary to study closely the differences of race, of circumstances, of degrees of civilisation, and to adapt the policy of the State intelligently and sympathetically to the special requirements of each. For this reason I have persistently urged that government by political parties, as in England, is inconsistent with the doctrine of equal rights for every civilised man in the present racial conditions of our tropical colonies. Those who insist on a form of government by universal suffrage, and hold that the only expression of equal right is equal franchise, may not be satisfied with less; but they are for the most part visionary counsellors without practical experience of the problems of Crown colony administration. I shall refer in the course of my narrative to the colony of Ceylon. It is a typical instance of a colony in which a Constitution without any system of electoral franchise has secured an equality of rights which it would have been impossible to secure by universal suffrage or by any uniform system of franchise. 


\section{CHAPTER II}

OUR NATIONAL POLICY

I $815-1868$

\section{CONDITION OF THE PEOPLE}

As the intention of my work is to illustrate a phase of colonial policy during the second half of the Victorian era, it may be thought irrelevant to dwell on the conditions of national life which determined the policy of the first half of that era in England. My reply must be that the colonial policy I propose to illustrate grew out of the national policy that preceded it; and I hope to show that the principles which worked out the social and economic salvation of England by methods appropriate to the national environment are capable of working out equally beneficent results by methods appropriate to the group of constituent parts of the Empire with which I am dealing.

The policy of England during the period following the Treaty of Paris in 1815 was dominated by the cult of Peace, Retrenchment, and Reform. It became a dogma of political faith that Peace, Retrenchment, and Reform constituted a trinity one 
and indivisible. In the leisure of peace a multitude of minds found time to survey the condition of the people, to recognise that the material and moral improvement of their condition constituted the only legitimate charge on the revenues derived from their labour in the development of national resources, and to realise from the experience of the past that the adjustment of this charge could only be effected through the agency of a reformed legislature. It will be my endeavour to illustrate the intimate bearing of the policy of Peace, Retrenchment, and Reform on the national life, and subsequently on the colonial policy of the United Kingdom during the period under review.

It must be borne in mind that while the Reform Bill of $1_{32}$ was the result of an irresistible movement having its origin in the condition of the people, a reform of the legislature was necessary to reveal that condition in its full significance. It was observed at the time that the first business of our reformed Parliament was to put all the world into commission, and that the amount of distress thus ascertained was such that the only surprising thing was that a universal disruption of society had not taken place.

Every history of the period abounds with evidence of the condition of the people taken from reports and authentic records. A passage from Alison's History of Europe on the report of a Committee of Enquiry appointed by the Ministry in I $84 \mathrm{I}$ may serve in illustration.

"In Carlisle, one-fourth of the inhabitants were found to be in a state bordering on starvation. In Stockport above half the master-spinners had failed, 
3,000 houses were shut up and uninhabited, and 5,000 persons were walking the streets in a state of idleness. At Leeds the heap of stones broken by the paupers had swelled to 150,000 tons, when all the workmen employed on it were taken into the workhouse. In Manchester, the sale of new clothes for the poorer classes had almost entirely ceased; nothing could find a market among them but shirts, and patches to mend the old garments. The condition of the shopkeepers, especially of the humbler class, was scarcely less distressing, while poor-rates were daily increasing beyond all precedent; their trade had sunk to a third, often not more than a tenth, of what it had been five years before. In Dorsetshire, the wages of an able-bodied labourer were only four shillings a week, and the best could not earn more than six shillings, and this with wheat at seventy shillings the quarter. In a word, the condition of the labouring poor in all the manufacturing districts was such that it could not by possibility become worse without multitudes being swept by absolute famine into an untimely grave."

Cobden describing the condition of Manchester in 1836 , wrote as follows :

"Manchester is supposed to contain 50,000 Irish, or the immediate descendants of Irish. The quarter in which they congregate is, like the district of St. Giles's of London, a nursery of all the customs that belong to savage life. In the very centre of our otherwise civilised and wealthy town, a colony which has acquired for its locale the title of Little Ireland, exhibits all the filth, depravity and barbarism that disgrace its patronymic land. Nor 
is the evil confined within such limits. Its influences are felt in the adulteration of character, and the lowering of the standard of living of our artisans generally : it is a moral cancer, that, in spite of the efforts of science or philanthropy to arrest its progress, continues to spread throughout the entire mass of our labouring population.

" No part of England or Scotland is exempt from its share in the natural consequences of this terrible state of degradation to which the people of Ireland are reduced. There is not a village or parish of the Kingdom into which its famine-impelled natives do not, at certain periods of the year, penetrate to share the scanty wages of our peasantry; thus dragging them down to their own level, and, in return, imparting to them the sad secrets of their own depraved modes of life."

The condition of Ireland itself in 1834 had been described by an intelligent traveller in this declaration :

"I, Henry David Inglis, acting under no superior orders; holding no Government commission; with no end to serve, and no party to please; hoping for no patronage, and fearing no censure; and with no other view than the establishment of truth,- -having just completed a journey throughout Ireland, and having minutely examined and enquired into the condition of the people of that country-do humbly report, that the destitute, infirm, and aged, form a large body of the population of the cities, towns, and villages of Ireland; that, in the judgment of those best qualified to know the truth, threefourth parts of their number die through the effects 
of destitution, either by the decay of nature accelerated, or through disease induced by scanty and unwholesome food, or else by the attacks of epidemics, rendered more fatal from the same causes: that the present condition of this large class is shocking for humanity to contemplate, and beyond the efforts of private beneficence to relieve, and is a reproach to any civilised and Christian country." 1

On this Cobden observed: "A Christian country, does he say? Posterity will doubt it! There is no such picture as this of a permanent state of national existence to be found in any authentic history, ancient or modern, Christian or Pagan." And on this I may observe that these phrases were hardly less appropriate to the general condition of the people of the United Kingdom.

But I am not writing a history of the period; I am concerned only to show the influence of the condition of the people on the colonial policy of the time. And as the conditions of national life, and the forces generated by them, are often best illustrated in drama and fiction, I shall be content to refer my readers for a vivid presentation of the condition of England during the period, to two historic works of fiction, Lord Beaconsfield's Sybil and Mrs. Gaskell's Mary Barton.

Sybil, or the Two Nations, represents the life of the people in the village, the factory, and the mine. In the village cottages, the rain pouring through the roof, without a fire on the hearth even in winter, approached through dungheaps, the labourer with his wife and family lived on eight shillings a week

${ }^{1}$ Ireland in 1834 ; by $\mathrm{H}$. D. Inglis. London, 1835 . 
or less. In earlier days the cottage had contained a loom, and the loom had given the owner wages and a garden. The home industry of the loom had given place to the factory; and with much elaboration the author of Sybil describes the life of the manufacturing towns where the inhabitants were losing the elementary virtues of humanity; factory girls deserting their parents for a life of independent vice; mothers farming out their children from the "dungheaps or holes which they called their homes," for threepence a week to nurses who soothed them with opium and syrup, with such results that "infanticide was practised as extensively and as legally in England as on the banks of the Ganges." The survival of the fittest in this environment, in the case of a child who "acquired" the name of Devilsdust, is thus illustrated:

"All his companions were disposed of. Three months' play in the streets got rid of this tender company, shoeless, half naked, and uncombed, whose ages varied from two to five years. Some were crushed, some were lost; some caught cold and fever, crept back to their garrets or their cellars, were dosed with Godfrey's Elixir, and died in peace. The nameless one, Devilsdust, would not disappear: he always got out of the way of the carts and horses, and never lost his own. They gave him no food: he foraged for his own, and shared with the dogs the garbage of the streets. But still he lived: stunted and pale, he defied even the fatal fever which was the only habitant of his cellar that never quitted it, and slumbering at night on a bed of mouldering straw, his only protection against the 
plashy surface of his den, with a dungheap at his head and a cesspool at his feet, he still clung to the only roof that sheltered him from the tempest. At length, when the nameless one had completed his fifth year, the pest which never quitted the nest of cellars of which he was a citizen raged in the quarter with such intensity that the extinction of its swarming population was menaced. The haunt of this child was peculiarly visited. All the children gradually sickened except himself: and one night when he returned home he found the old woman herself dead and surrounded only by corpses."

The life of the factory was thus summed up by an artisan:

"There is more serfdom in England now than at any time since the Conquest. I speak of what passes under my daily eyes when I say that those who labour can as little change or choose their masters now as when they were born thralls. There are great bodies of the working classes of this country nearer the condition of brutes than they have been at any time since the Conquest. Indeed, I see nothing to distinguish them from brutes, except that their morals are inferior. Incest and infanticide are as common among them as among the lower animals. The domestic principle wanes weaker and weaker every year in England: nor can we wonder at it when there is no comfort to cheer and no sentiment to hallow the home."

Passing from the factory to the mine, we are confronted with this terrible picture:

"Bands of stalwart men, broad-chested and 


\section{THE BROAD STONE OF EMPIRE}

muscular, wet with toil, and black as the children of the tropics. Troops of youth, alas! of both sexes, though neither their raiment nor their language indicates the difference-all are clad in male attire; and oaths that men might shudder at, issue from lips born to breathe words of sweetness. Yet these are to be, some are, the mothers of England! But can we wonder at the hideous coarseness of their language, when we remember the savage rudeness of their lives? Naked to the waist, an iron chain fastened to a belt of leather runs between their legs clad in canvas trousers, while on hands and feet an English girl, for twelve, sometimes for sixteen, hours a day, hauls and hurries tubs of coal up subterranean roads, dark, precipitous, and plashy; circumstances that seem to have escaped the notice of the Society for the Abolition of Negro Slavery."

The scene of Mary Barton is laid in Manchester. It described a workman's home in a cellar, everything pawned, the stagnant, filthy moisture of the street oozing up through the floor, the fireplace empty and black, the wife crying in the squalid loneliness, the little children "too young to work, but not too young to be cold and hungry," rolling on the filthy floor. But while depicting the misery and the vice of their environment, it enlisted not only pity but sympathy for the "germs of almost impossible good" revealed in the "sacred patience of the poor." It exhibited distress submitted to without surprise and generally without murmur as one of the appointed incidents of their lot; and did justice to another feature in the character of the 
operative poor, perhaps even lovelier and brighter than their wonderful patience under suffering, in their mutual helpfulness and unbounded kindliness towards each other. "There were desperate fathers ; there were bitter-tongued mothers ( $\mathrm{O}$ God! what wonder); there were reckless children; the very closest bonds of nature were snapped in that time of trial and distress. But there was faith such as the rich can never imagine upon earth; there was 'love strong as death,' and self-denial among rude, coarse men, akin to that of Sir Philip Sydney's most glorious deed. The vices of the poor sometimes astound us here; but when the secrets of all hearts shall be made known, their virtues will astound us in far greater degree."

These illustrations of the condition of the people, drawn from the truth and romance of prose and fiction, may be conveniently supplemented by reference to Hood's two famous poems, The Song of the Shirt and The Bridge of Sighs. They give the most pathetic picture ever presented of the misery of the working women of England at that time. They were written in the early Forties, at the time when the free trade agitation was at its height, and it was hoped that vast improvement in the condition of the working women of the country would be the crown of the edifice to be constructed on the policy of free trade. Hood's "Unfortunate, weary of breath," had her choice of three courses: "Stitch, stitch, stitch," from morning till night for the wages of a few farthings, dishonour, or death.

Such was the condition of England, as the result of centuries of a system accepted as civilisation. 


\section{THE BROAD STONE OF EMPIRE}

The problem of the day was to find its causes and its cure.

Its immediate causes were obvious. War and famine had exhausted the resources of Europe. At home the people were starving; misery and unrest filled the land. Abroad the prodigious expenditure of capital that war had demanded, the wasteful consumption of armies, confiscation, and the rapine of predatory hordes, had ruined the Continent. The people could barely maintain existence. They had little to spare for comfort, and nothing for indulgence. The merchants of our own country, accustomed to the outward indications of prosperity at home during the course of the great struggle, had no adequate idea that war was the great destroyer of capital, and left all mankind the poorer. As there was no money on the Continent to exchange for British products, commerce found everywhere depression and stagnation. There was consequently a surplus of labour in every department of human industry. In respect of the agricultural population especially it had been declared in Parliament in 1816 that "the poor in many cases abandoned their houses and parishes, and sought shelter and food elsewhere. Whole parishes were deserted; and the crowd of paupers increasing in numbers as they went from parish to parish, spread wider and wider the awful desolation."

Discharged sailors and disbanded militia-men swelled the ranks of indigence. If the unhappy wanderers crowded to the cities, they encountered bodies of workmen equally wretched, wholly deprived of work, or working at short time upon insufficient 
wages. The distress which had fallen upon the manufacturing and other non-agricultural portions of the population was manifested in many signal ways. At first it took the form of peaceful demonstration. In July, i8r6, a body of colliers, thrown out of employment by the stoppage of ironworks at Bilston, took the singular resolution of setting out to London, for the purpose of submitting their distress in a petition to the Prince-Regent, and presenting him with two waggon-loads of coals, which they drew along with them. The men, who had conducted themselves with the most perfect order, were satisfied to depart homewards, having been paid for their coals, and accepting also some charitable contribution. They bore a placard, Willing to work, but none of us to beg, and they demanded from the magistrates certificates that they had conducted themselves with propriety.

But the inevitable burden of taxation consequent on the exhaustion of capital, the depression of agriculture, and the want of markets for the products of manufacture, had caused a paralysis of industry soon to be followed by less peaceful demonstrations. Under the pressure of strikes of a formidable character, it was not to be wondered at if artisans and peasantry alike thought of the French Revolution as a proof that men had only to take matters into their own hands to obtain whatever they wanted. In their own way they took matters into their own hands. In the towns, the people rose up against the power looms, which they believed to be the cause of their distress. In one day every power loom in Blackburn, and within six miles of it, was destroyed. 


\section{THE BROAD STONE OF EMPIRE}

Machine breaking went on to such an extent, that men were tried for the offence in groups of twelve or twenty at a time; in the country, nights were lighted up by burning barns and ricks.

It has often been asserted, and is still asserted by demagogues in quest of popularity, that there are only two sources of property,- - production and plunder. It is a declaration that leads to perilous fallacies, but the history of all ages proves conclusively that when, in circumstances such as have been indicated, the national markets are closed to productive industry, the natural instinct of the unemployed finds an area of activity in plunder. So it was during the period I am dealing with. The objects of plunder were two,- - the public revenue and private property; and the methods were two,violence and fraud. A profitable market for the industry of plundering the public revenue by violence and fraud had been prepared by the fiscal policy of six centuries.

I am not concerned here to discuss the question of Protection or Free Trade in its bearing on the fiscal policy of the present day, but only in its bearing on the popular movement arising out of the condition of the people during the period immediately preceding the abolition of the Corn Laws. But in the language of politics the term Protection has come to be applied so exclusively to the protection of the industry of agriculture, that the evolution of the fiscal policy known as Free Trade is almost forgotten. The story was so concisely told in 1870 by Mr. Dudley Baxter that the earlier part of the narrative may be conveniently reproduced in his own words: 
"Free Trade was one of the stipulations made by the English Barons in Magna Charta, which in its forty-first clause provides 'that all merchants shall have safety and security in coming to and going out of England, and in remaining and travelling through it by land or water for buying or selling, free from any grievous impositions, and agreeable to the old and upright customs.' These guarantees were renewed by the Foreign Merchants' Charters of the First and Third Edwards, which enumerate the duties which the Merchants had 'unanimously agreed to pay' in return for the protection.

"But the Towns were continually engaged in contests with the foreign traders, endeavouring to drive them out of the Kingdom or harass them with heavy contributions. The Kings generally protected the foreigners, but in the Wars of the Roses the House of York gained support from the Londoners by espousing the popular cause. During the three centuries which preceded the Great Rebellion, the Town policy gradually prevailed, of restrictions of greater or less importance on foreign commerce and protection for the home trade, together with prohibitions on the export of corn whenever its price exceeded a low average. These laws gave rise to many retaliatory regulations and even wars by foreign states.

"A new mode of restriction was obtained by the English Merchants under Henry the Seventh, by a law forbidding the importation of some kinds of goods except in English ships. A second law under Elizabeth shut out foreigners from the Coasting trade. The third and greatest, known as 'The 


\section{THE BROAD STONE OF EMPIRE}

Navigation Act,' under Cromwell, and directed by him against the Dutch carrying trade, prohibited the importation of merchandise from Asia, Africa, or America, except in English built ships, and from Europe except in ships belonging either to England or the importing country.

"After I688 the system of heavy import duties for the encouragement of native industry became the fashion in Europe, and was zealously adopted in England; at the instance of the manufacturers and town populations who were strong supporters of the Whigs. Prohibitory duties were imposed on foreign commodities. The export of raw materials and half finished articles was forbidden. Bounties were given on the export of many British articles and of corn. The trade and manufactures of Ireland were crippled by severe restrictions."

For nearly a century a slow but steady tendency in favour of Free Trade was supported by the Tory Party, who derived little advantage from the protective system, and suffered from the artificial prices it maintained. The strenuous efforts of their great leader Pitt in favour of Free Trade principles were, however, arrested by the Revolutionary War in I 792, which caused an immense change in the position of the landed interest. "Until I 788 ," in the words of Mr. Baxter's narrative, "England had been a corn exporting country, and though for three hundred years importation had been prohibited below certain prices, the protection had been practically unfelt. But the increase of manufacturing industry and population that now took place outstripped the pro- 
duction of food; and with the war and a paper currency combined to raise the prices of grain to an extraordinary height. Great quantities of poorer land were enclosed, and rents rose enormously. During that long series of years the agricultural interest was placed on a high and artificial level, descent from which on the conclusion of peace seemed ruin. The protection which had been so long accorded to Manufactures appeared a necessity for Agriculture also, and was justified by a hundred precedents. Hence in 1804 and I 815 , by a combination of the landed proprietors of both political parties, more stringent Corn Laws were passed, raising the price at which free import was allowed from its former figure of 54s. to 66s. and 8os.; and the landed interest became identified with Protection."

Admitting, and I do not think it has ever been seriously denied, that the protective policy of six hundred years was the basis of England's manufacturing supremacy, it had, among other consequences, encouraged and promoted evasion of the law by an organised system of smuggling. In this industry numbers of unemployed found an attractive area of activity. A writer of the time has thus described the operation of the system and its consequences.

"There were strange doings by night in the creeks and hollow-ways and caves of the southern coast ; and a remarkable order of passengers by day in the packets from France. Every now and then a fisherman's great boots were found to be stuffed with French lace, gloves, or jewellery; or a lady's petticoats to be quilted all through with silk stock- 
ings and lace. Here and there, a nice-looking loaf of bread was found to have a curious kernel of lace and gloves; and a roll of sailcloth turned out to be a packet of gay lute-string. In the dead of the night a large body of men would work for hours noiselessly in the soft sands, rolling tubs of spirits, and carrying bales of goods in the shadows of the rocks, and through tunnels, and up chasms, under the very feet of the preventive patrol, and within sound of the talk of the sentries. While this was going forward on the English coast, the smugglers on the opposite shore were engaged, with much more labour, risk and expense, in introducing English woollens, by a vast system of fraud and lying, into the towns, past a series of custom-houses. In both countries there was an utter dissoluteness of morals connected with these transactions. Cheating and lying were essential to the whole system ; drunkenness accompanied it ; contempt for all law grew up under it; honest industry perished beneath it; and it was crowned with murder. Little children who lived near a smuggling haunt learned early to be sly, and to say anything that was convenient. Their mothers stole down to the sands at night to bring up light goods which they might hide in the rafters of the cottage, and spread temptingly before any foolish ladies within their reach. Or, if they did not themselves meddle, they reproached their husbands for working at the plough or the anvil when certain neighbours could make a pocketful of money in a night. As for the men, they were tapping a cask of spirits when their work was done at dawn, and passing the daylight hours in a drunken sleep, in some hidden place, 
instead of being at honest labour in the field or in the shop. Then, if the expected boat did not come in, they would not meet for nothing, but go poaching in the nearest preserves. When detected, which was sure to happen pretty often, a conflict ensued, and the newspapers of the time abound in notices of preventive men and smugglers shot." 1

Mr. Gladstone, in a speech on the desolating power of war, declared that, "It reduces many to positive want who in times of peace have been in easy circumstances. It suspends, ipso facto, every rule of public thrift, and tends to sap honesty itself in the use of the public treasure for which it makes such unbounded calls; it, therefore, is the greatest feeder of that lust of gold which we are told is the essence of commerce, though we had hoped it was only its occasional besetting sin. It is, however, more than this; for the regular commerce of peace is tameness itself compared with the gambling spirit which war, through the rapid shiftings and high prices which it brings, always introduces into trade. In its moral operation it more resembles perhaps the finding of a new gold-field, than anything else." The truth of this proposition was never more clearly demonstrated, than in the consequences of the Revolutionary War. The gambling spirit generated by the long period of war, finding its area of activity limited by the stagnation of legitimate trade and commerce, applied itself to scheming manœuvres, and promoted a general rage for speculation. The policy of calling in the new world to redress the

'History of England during the Thirty Years' Peace; by Charles Knight and Harriet Martineau. London, I849-50. 


\section{THE BROAD STONE OF EMPIRE}

balance of the old inspired the ban and arrière-ban of the regular and irregular forces of finance. As usual during periods of an epidemic of gambling, the propositions submitted to the public ranged from enterprises of the most intelligent foresight and of the noblest uses to humanity to schemes of deliberate fraud or grotesque impudence. Among the former was a canal to unite the Atlantic and Pacific; among the latter an association of Scotch milkmaids to supply Buenos Ayres with butter. Between these extremes was a perplexing amplitude of choice among propositions to obtain gold and silver from the Andes, pearls from the Coast of Columbia, and speculative enterprises of every description warranted to provide wealth beyond the dreams of ambition. Needy, but intelligent, speculators, scheming attorneys, and gamblers of every class, used their opportunity, first, for exciting the gambling spirit everywhere within their reach, and then for introducing themselves into a society which at other times would have been sternly closed against them. They knew that their opportunity was short, and they used it diligently.

It would have been well if the rage for speculation had been confined to men engaged in trade. The madness spread everywhere. Retired professional men living on their acquired fortunes, ladies deriving all their income from the funds, families who had lent their money on mortgages, looked on the one hand at the low interest on money, and on the other at the enormous profits made by speculation, and grew dissatisfied. Some who went on in their ordinary course, untouched by the madness of the 
time, were reproached for injustice to their families, in declining to help themselves from the stores of wealth so lavishly poured around them. ${ }^{1}$

The epidemic of speculation had its logical consequence in a financial crisis which intensified the sufferings of every class of the nation. As bank after bank failed, whole families were reduced to destitution. In the general catastrophe the ties of family, strained by cupidity, were snapped by disappointment and discontent. Before the exasperating spectacle of the most guilty rewarded, while the most innocent were involved in the general retribution, hope, faith, and charity alike gave way.

While smuggling and speculation were affecting the destiny of the nation through the operation of fraud and violence organised by intelligent leaders, the free lances of crime were not idle. What may be called occasional crimes, arising out of individual exigencies and directed against private and personal property, abounded,--theft, burglary, arson, and murders for the purposes of theft by individuals or in combination, murders that reached the nobleman in his bed and the labourer at his task.

While the condition of the people was thus imperilling society, the experience of the Government, based on the accepted principles of civilisation, could suggest nothing better than a cure that proved worse than the disease,- - the application with everincreasing severity of the rigors of the penal code. The social disorders which had their origin in poverty were treated by the harshest methods

${ }^{1}$ History of England during the Thirty Years' Peace: ut supra. 


\section{THE BROAD STONE OF EMPIRE}

the Constitution could be made to yield or to countenance.

As England advanced in civilisation her laws had retrograded into merciless and indiscriminate severity. A system had grown up of making the lightest as well as the most serious offences capital, that the gallows might stand as a scarecrow. "Life was held cheap, compared with property. To hang men was the ready expedient of thoughtless power. From the Restoration to the death of George the Third, a period of 160 years, no less than 187 capital offences were added to the Criminal Code."

Under this system men were brought out upon the scaffold in batches, and hanged in rows. Boys of seventeen, hired to steal sheep or to pass forged notes, were hanged with the able-bodied burglar and the hoary old coiner. The day before an execution the jail was crowded with the families of the doomed men come to bid them farewell. Six or eight wives together, to be widows to-morrow; fifteen or twenty children, to be orphans to-morrow, - these were the moaning and weeping reprovers of our law, so barbarous at so late a day!

To this economic and moral peril a visitation of cholera in $\mathrm{I}_{3} \mathrm{I}$ added a fresh cause of alarm, and compelled attention to the appalling sanitary condition of the nation, of which sufficient indications have already been offered. 


\section{CHAPTER III \\ OUR NATIONAL POLICY \\ I 8 I 5-I 868}

II. REFORM

THE policy of the early Victorian era was well summed up in the terse formula Peace, Retrenchment and Reform, but in discussing this formula, it will be more convenient to reverse the order of sequence; to illustrate first the nature and scope of the measures of reform contemplated, and then proceed to show that the successful issue of these measures was dependent on measures of retrenchment inseparable from a policy of peace.

Superior in importance to all other measures of reform was the reform of the agency that had supreme control over the rest. Such, indeed, was its recognised superiority that, spelt with a large $R$, it has in parliamentary phrase appropriated to itself a particular, and even an exclusive use of the term.

Government is the exercise by a few of the power necessary for the protection of all, a power that may be acquired by assumption or delegation. Its professed purpose is to maintain order, to prevent the 
strong from plundering the weak, and to assure to every man the greatest possible share of the produce of his own labours. But all governments have been subject to the law of human nature that a man will, if he can, take from others anything they have which he desires; and this is in its turn subject to the universal law that action and reaction are equal and opposite, under the operation of which, when the constituted guardians have become plunderers, the reaction of the community has terminated their authority by revolution or limited it by reform.

The history of civilisation is a record of conflict between a class by whose manual labour the natural resources of the earth are developed, and another by whose strength and intelligence the fruits of that labour are appropriated. These two classes have been known by many names, Patricians and Plebeians, Aristocracy and Democracy, Capital and Labour, Rich and Poor; but in practical politics the line of cleavage has always coincided with the cleavage between the governing class and the governed,in other words between the Government and the People. And this line was the resultant of three forces, landed property, personal property, and labour. The evolution of these forces in the British Constitution may be briefly traced.

The leading principle of the feudal system, the origin of the British Constitution, was that the king was sole absolute owner of all the land in the kingdom. The chief lords held their lands from him on condition of military and other services; their vassals held from them on similar conditions, 
and so on in an extended chain of vassalage, each vassal owing fealty to his immediate lord, but to no other. In this way there grew up a concourse of practically independent lords, each of whom was supreme landowner and representative of his vassals. In the year 1086, however, William the Conqueror summoned "all his witan and all the landowners of substance in England whose vassals soever they were, and they all submitted to him, and swore oaths of allegiance to him that they would be faithful to him against all others." Under this system, accordingly, the whole land became divided among a small number of families who were not only lords of the soil, but of the inhabitants, and the right of governing acquired by assumption descended with the family inheritance from generation to generation. Landed property was then the sole source of power, and force being the only means by which man could act on man, all title was held by the condition of military service. In time the secularisation of the Church introduced the political power of the clergy. The Church opened its ranks to all classes, to the lord and the serf, and through the Church by the instrument of education, of which it had the sole use, the principle of equality so penetrated into the government, that a man who, as a serf, must have vegetated in perpetual bondage, might take his place as a priest among nobles, and even, as not infrequently happened, above the heads of kings. As the relations of humanity became more complex, the want of civil laws became felt, and an order of legal dignitaries, also owing its origin to the education supplied by the Church, took their place at the 
court of the Monarch by the side of barons and dignitaries of the Church.

The Constitution thus assumed the form of government by a Monarch, dependent on the triple powers of the Army, the Church, and the Law, exercising absolute control over the lives and liberties of the people. While the Church presented the tremendous issue of Heaven or Hell in the future, that motive to obedience was enforced by the immediate alternative of earthly happiness or the most terrible penalties that human ingenuity has devised by award of the Law, to be exercised, if need be, manu militari. Although the revolt against the Church, known as the Reformation, was a result of the cosmic law of reaction, and had supreme consequences, it did not at the time affect the balance of power between the governing class and the people; it merely replaced the tyranny of one Church by the tyranny of another. The principle of government by physical force in Church and State remained supreme. The constitutional liberty of the people was to come from another source. While the kings were ruining themselves by great enterprises, and the nobles exhausting their resources by private wars, the lower orders were finding a new avenue to power by commerce. Neither the possession of land nor the development of its resources by the elementary operations of manual labour can be made profitable without intelligent distribution, and out of the lower orders there arose a body of men who learnt to enrich themselves by the profit of transactions in purchase and sale. Gradually the influence of money accumulated in 
trade began to be perceptible in State affairs, and the capitalist, as financier, rose to a station in which he was despised but courted. The result has been summarised by M. de Tocqueville, as follows :

"The crusades and the wars of the English decimated the nobles and divided their possessions; the erection of communities introduced an element of democratic liberty into the bosom of feudal monarchy; the invention of fire-arms equalised the villein and the noble on the field of battle; printing opened the same resources to the minds of all classes; the post was organised so as to bring the same information to the poor man's cottage and the palace gate; and Protestantism proclaimed that all men are alike able to find the road to Heaven. The discovery of America offered a thousand new paths to fortune, and placed riches and power within the grasp of the adventurous and the obscure."

Under these influences great changes took place: the government became more and more secular; the Church lost its power of tyranny, but did not cease to be considered as an effective instrument of order in forming the character of the citizen by doctrine and example, without infringement of his innate right to think for himself and to propagate his thoughts. The very existence of a standing army came to be considered a menace to liberty. The Law, no longer dominated by the doctrine of the Church that the issue of Heaven or Hell, in this world as in the next, was the only efficient motive of obedience, relaxed its terrors. Above all, the transition of individuals from the lowest orders to the highest in Church and State had established the 


\section{THE BROAD STONE OF EMPIRE}

sentiment that every British subject in the lowest order must be considered as a potential member of the highest.

The leaders of the Reform movement after the peace of 1815 had then to consider, first, the result of the evolution, under the operation of these influences, of the three forces of landed property, personal property, or capital, and manual labour, and secondly, a measure to give them a fair share of representation in the House of Commons.

The population of the United Kingdom was divided into three classes, upper, middle, and lower, by sufficiently clear lines of demarcation. The upper class included the nobility, the landed gentry, the dignitaries of the Established Church and of the Law, a group of capitalists attached by social alliance to the other constituents of the class, and a few distinguished servants of the State. The middle class included the general body of members of the learned professions, officers of the Army and Navy, the Civil Service, and the corresponding staff of commercial and industrial enterprises of every description. The lower class, generally styled the Working Classes, included all engaged in the manual and elementary labours of agriculture, manufacture, and commerce, and in the menial services of domestic life.

In considering the constituent elements of these classes and the nature of the bond between them, it is easy to see how profoundly they had been modified by the expansion of England. The area of power and profit derived from landed property during the feudal ages was confined to the narrow 
limits of English territory in Europe, while the expansion of England brought to capital the profits derived from the land, in constantly enlarged areas in America and Asia. The colonial policy known as the Mercantile System had made the continent of North America, the islands of the Caribbean Sea, and the East Indies contributory to the profits of capital. American "proprietors," under the proprietary system of colonisation, and the directors of chartered companies, West Indian planters and East Indian nabobs, had acquired fortunes beyond the dreams of ambition. Their blood flowed into the veins of half the aristocracy; their wealth built up the fortunes of many a noble family, and laid the foundations of vast commercial enterprises at home. Nor were the sources of commercial profit limited even to the considerable area of British possessions; the supremacy of the sea brought the whole world under contribution. In this way capital came to associate itself with landed property in a close political union, all the more important from its influence on the relations of the State to the Church. Although the temporal power of the king and the barons during the feudal age had been nominally supreme, it was a supremacy really subordinate to the ascendancy of the Church. As has been pointed out, the Reformation only transferred this ascendancy from one Church system to another. It was under the influence of the Church that Portugal sent expeditions to Africa and Asia, that Spain led the way to Southern and Central America, that France engaged in the conquest of Canada. The ostensible motive of all these enterprises was to establish 


\section{THE BROAD STONE OF EMPIRE}

Christianity, the result to establish an extra-territorial secular supremacy under the ascendancy of the State Church. But the influence of religion as a motive of English expansion was of a quite different order; it encouraged Protestants against the ascendancy of the State Church to emigrate in order to escape persecution, and subsequently led them to establish the religious ascendancy of their own creed. The expulsive power of a new affection, a new interest, a new ideal is a cosmic law which has never been more effectively demonstrated than when it substituted the frankly secular influences of capital for the spiritual influences of the Church. While the closer association of capital with the landed interest was modifying the characteristics of the upper or governing class, it was even more profoundly modifying the characteristics of the middle class. So long as the governing class had a dominant control in the nomination or election of members of Parliament, and a practically exclusive privilege and monopoly of control in the appointment of every officer in the public service, the middle class was composed mainly of officers of the Army and Navy, Civil Servants, lawyers and clergy, and, to a very large extent, these were members or adherents of the families of the landed gentry. Generally speaking, the qualifications of the class were the patronage of the landed gentry, and, in the case of the civil element, a classical education. Capital introduced the classes that stood to commerce and industry in a position analogous to the relation of the Civil Service to the landed gentry; their qualification was employment 
in the service of capital and a competent education, on what is now called the "modern side," in foreign languages and applied science. This extension brought in the servants of the East India Company and similar enterprises engaged in colonisation and commerce, and generally the staff of the mercantile marine and of the railways, with a side range of subsidiary interests in constructive and mechanical engineering. As this section of the middle class increased in competence and numbers, it exercised a constantly increasing influence on the lower class from which it was mainly recruited, the qualification being practical skill acquired in the elementary labour of industry and commerce, and an intelligent use of the limited educational opportunities available.

To secure a fair share of representation in Parliament for the groups of interests included in these three classes was the object of the promoters of the Reform movement. Hitherto the privilege of a seat in Parliament as the delegate of an interest had been acquired by assumption or by purchase. We have seen how the landed interest acquired the privilege by assumption; generally speaking, capital acquired it by purchase, - either by the purchase of land, a county property, or a "rotten borough" originally represented by assumption, or by purchase of the votes of individual electors. So far, therefore, as the middle classes were represented in Parliament, they were only represented by nominees or agents of the amalgamated influences of the landed interest and capital. A history of the movement to reform the parliamentary system of the great families 
thus amalgamated is beyond the scope of my purpose. It must suffice to say that, during the period I am dealing with, two great measures of Reform successively widened the democratic basis of the House of Commons. The Reform Act of 1832 gave a preponderance of power to the middle classes, but expressly excluded the working classes. The Act of 1867 gave a large share of power to the working classes. At a later period the Act of 1884 gave the working classes a preponderant power.

I have indicated the principal stages that marked the evolution of the House of Commons from absolute monarchy through aristocracy to democracy, and have endeavoured to show that the Reform Act of 1832 had for its ultimate aim a fair division of labour, if I may so express it, between these three forces. The policy by which this aim was to be reached was a policy based on two great principles,-retaining the power of the State in the hands of the less numerous but more select, more cultivated, and more competent classes; and making entrance into these classes accessible to all. The union of these principles has proved the safety, first, of the English nation and, secondly, of the British Empire; their disjunction has been the ruin of all antecedent empires. It is important, therefore, to realise that through the period of conflict which resulted in admitting the working classes into the sphere of operation of this policy, the House of Lords, formidably assailed as it was, emerged with powers practically undiminished. The three great stages of evolution of our constitutional history,-Magna Charta, the Reformation, and the Revolution of 
I688-had shown the struggle for liberty under the influence of the general law of humanity and the cosmic law of action and reaction already exhibited, and had always resulted in the struggle for liberty ending in a struggle for the control of a tyranny. It was realised that, if the new system was left to follow the operation of these laws, the struggle of the democracy for liberty could have no issue but a tyranny more formidable than any that had preceded it. Land and capital were alike alarmed at the general tendency of the democratic spirit to make concessions to popularity out of the public revenue, and to equip at the general expense the lower and weaker against the higher and wealthier classes of the community. It was necessary to find security against this tendency in an institution that had its roots in the traditions and sentiment of every class. The forces of reason and sentiment that had preserved the House of Lords in $I_{32}$ were well described by Cobden in 1836 :

"They who argue in favour of a republic, in lieu of a mixed monarchy, for Great Britain, are, we suspect, ignorant of the genius of their countrymen. Democracy forms no element in the materials of the English character. An Englishman, is, from his mother's womb, an aristocrat. Whatever rank or birth, whatever fortune, trade or profession, may be his fate, he is, or wishes, or hopes to be an aristocrat. The insatiable love of caste that in England, as in Hindostan, devours all hearts, is confined to no walks of society, but pervades every degree from the highest to the lowest. Of what conceivable use, then, would it be to strike down the lofty patricians 


\section{THE BROAD STONE OF EMPIRE}

that have descended to us from the days of the Normans and Plantagenets, if we of the middle class-who are more enslaved than any others to this passion-are prepared to lift up, from amongst ourselves, an aristocracy of mere wealth-not less austere, not less selfish-only less noble than that we had deposed."

Wisely, therefore, it was decided to retain the House of Lords as a security against the enfranchisement of the middle classes being made the instrument of transferring to them the control of a tyranny. And a few years later the enfranchisement of the working classes was safeguarded by preserving the same institution. In $1846 \mathrm{Mr}$. Disraeli, speaking of a transfer of power threatened by changes then impending, said :

"If there is to be this great change, I, for one, hope that its foundations may be deep, and the scheme comprehensive, and that, instead of falling under the thraldom of Capital-if we must find a new force to maintain the ancient Throne and immemorial Monarchy of England-we may find that novel power in the invigorating energies of an educated and enfranchised people."

Such, in brief, was the history of the evolution of the British Constitution through successive stages of tyranny exercised by the King, Lords, and Commons to a system based on the social principle of co-operation by the three estates of the realm as a means to an end,- - the end being the preservation of order in the country, the equilibrium of a just balance of classes, and the prevention of any predominance or tyranny of one class over another. 
It is often stated that to speak of the King, Lords, and Commons as the three estates of the realm is the result of a modern misconception. It is, in truth, the result of a modern fact.

The secularisation of Christianity under the Emperor Constantine has been declared to be the greatest misfortune that has in modern times affected the destiny of the human race. It is at all events certain that it brought the Christian Church under the operation of the laws that have acted on the evolution of the temporal power. When the tyranny of the Roman Catholic had made way for the tyranny of the Protestant, the secular world decided that the only safe issue from the dominion of the Church was to be found in a frankly secular system of government. The causes which transferred the tyranny of the Church to the tyranny of capital have been already indicated. Although the Lords Spiritual continue to sit in the House of Lords, they do not vote as a separate order. Since Convocation gave up its right to taxation, and the clergy of the Church of England, though permitted to vote in the election of members of the House of Commons, were debarred from sitting as members, it cannot be said that the clergy still form a separate estate.

In 1849 the questions of granting constitutions to the Australian colonies was referred to a Committee composed of the ordinary members of the Board of Trade assisted by Lord Campbell, Sir James Stephen, and Sir Edward Ryan, and the Queen in Council subsequently approved their report. That report advised "that the political institutions of the 


\section{THE BROAD STONE OF EMPIRE}

British Colonies should be approximated as nearly as possible to those of the United Kingdom by establishing a Governor, a Council, and an Assembly, after the analogy of the three estates of the Queen, Lords, and Commons." I shall elsewhere have occasion to refer to the measures taken in accordance with this report. At present I am concerned only to show that the principles of the Reform Acts of $183^{2}$ and 1867 have controlled the constitutional system of every constituent part of the colonial empire.

The Reform Act of $183_{2}$ was, as has already been shown, only the means to an end,-to the passing, that is to say, of certain measures necessary to remove the causes which had rendered the condition of the people intolerable. While the variety of these causes led to various movements acting coincidently, it will be convenient to deal with them in a certain logical sequence, under the heads of Law, Religion, Education, and Commerce.

Allusion has already been made to the merciless and indiscriminate severity of the criminal law of England and its bearing on the condition of the people. A revision of that law, long contemplated but constantly frustrated, was now recognised to be a national duty of the first concern. Mr. R. Dudley Baxter in a pamphlet, published in 1870 , on English Parties and Conservatism has given a summary narrative of the work accomplished during the period dealt with in this chapter.

The criminal law of England was contained in an immense and confused mass of documents, statutes, ancient and modern records, reported deci- 
sions of the judges, and text-books. It was clearly impossible for each individual lawyer to deduce the law as he wanted it from all these repositories; and if the profession proceeded on tradition, or in conventional agreement with regard to the most commonly occurring cases, it seems equally clear that a system of law constructed on the unstable foundation of what Lord Westbury styled "the rubbish called cases" could not be of much practical use. It ill befitted a civilised State and an enlightened age that the criminal law should not be clearly ascertained, and laid down in some depository accessible to all. This great work was entrusted, in 1833 , to a Royal Commission, whose business it was to enquire how far it might be expedient to reduce the whole criminal law of the country, written and unwritten, into one digest; and to report on the best manner of doing it. In I 834 the Commissioners reported in favour of the object, and they forthwith proceeded with their work. One of the immediate results of their labours was the Bill passed in 1836 for allowing the assistance of counsel to prisoners in criminal cases.

Sir Samuel Romilly was the first great reformer of our criminal law, and year after year he pressed upon the willing Commons and the unwilling Lords Bills for the repeal of the death-penalty for small offences. All the great lawyers were against him, and a single Act of Parliament was the sole fruit of his labours. After his untimely death they were continued by an eminent Whig statesman, Sir James Mackintosh, who obtained a Committee of 
Investigation in 1819 , and succeeded in passing three of the measures they recommended.

Sir Robert Peel adopted the views of Mackintosh, and undertook, as Home Secretary of the Tory Government, the revision of the Criminal Code. In five statutes, passed after his retirement from office, he consolidated the criminal law, and very considerably mitigated its severity. These enactments were followed by other reforms, and he was able, in his address to his constituents in 1835 , to take credit for the revisal of the whole system of trial by jury, and for his efforts to amend other branches of the jurisprudence of the country.

After $1_{32}$ the Whig Ministry passed a series of measures for the abolition of capital punishment, gradually lessening the number of crimes to which it was applicable, until, in I84I, it was abrogated for nearly all offences, and at last, in $\mathrm{I} 86 \mathrm{I}$, confined to murder and high treason. The sentences of death fell from an average of nearly i 300 a year between I 823 and I 832, with fifty-six executions, to an average of fifty a year between ${ }^{8} 82$ and 1862 , with eleven executions.

Inseparable from the question of the restriction of capital punishment to crimes of capital danger to the State and private life, was the question of the public execution of criminals. It was declared with truth that, "Vice and Crime held their saturnalia while Folly looked on from dear-bought seats in adjacent windows." Nevertheless, as late as i 864, a proposal made in Parliament that executions should be privately conducted was resisted by Sir George Grey, the Home Secretary, on the ground that such 
scenes, horrible as they were, "had a salutary effect on the people who witnessed them." Subsequently, however, the matter was referred to a Royal Commission who recommended inter alia that the punishment of death should be carried out privately inside the prison walls. After much opposition, this recommendation was given effect to by a law passed in I868. It may be mentioned incidentally that the last man publicly hanged in England, a month before the passing of the Act, was the Fenian, Michael Barrett, convicted of the crime of blowing up the wall of Clerkenwell prison. It is more interesting to note that the recommendations of the Royal Commission included proposals, "That murders should be divided into two classes: first, those which were deliberate, or which were perpetrated for the purpose of escape from the consequences of crime, and which the Commissioners recommended should continue to be punishable by death; and, second, those which were unpremeditated, or which, like ordinary cases of infanticide, were, in public opinion, undeserving of the death penalty; these crimes the Commissioners recommended should be punishable by penal servitude." A Bill to give effect to these recommendations was introduced in the House of Lords in I 866 but abandoned. It is needless to add that they have never yet been carried out.

Meanwhile, the spirit which prompted the restriction of the penalty of death and the method of execution was mitigating the severity of the criminal law in the use of instruments subsidiary to the gallows, the pillory, the stocks, and the lash, as well 


\section{THE BROAD STONE OF EMPIRE}

as in the methods of prison discipline. In 1815 the punishment of the pillory was limited to the crime of perjury; in 1830 it was abolished. In 1826 the last stocks were removed from the city of London, though the punishment continued to be used till I 865. Though the punishment of the lash still exists, the barbarous severity of its use was restricted both at common law and by sentence of martial law. At the beginning of the nineteenth century mutiny and other grave offences against military and naval discipline were frequently punished by sentences of a thousand lashes. In 1810 William Cobbett was prosecuted and punished for publishing censures on flogging in the army. Owing largely to the severe use of the lash during the campaign in the Crimea, public opinion was brought to bear on Parliament, and in 1859 the power of a court-martial to inflict corporal punishment was confined to limits which were subsequently further restricted. The severity of naval discipline led Dr. Johnson to declare that it was difficult to understand how a man with sufficient intelligence to get himself into prison could allow himself to be impressed into the navy. It was certainly not difficult to get into prison, and to our modern judgment it is difficult to believe that any conditions of existence can have been less attractive than the appalling conditions of prison life until the comprehensive schemes of reform were initiated by Acts passed in 1835 and 1839 . By these Acts rules of administration were laid down and inspectors appointed to see that they were carried out. The experience gained under the operation of these Acts led to the passing of the Prison Act (1865) which 
enacted a code of rules for all prisons, and recognised the principle of a classification of prisoners according to the nature of offence on conviction, and according to their conduct during imprisonment. In I $862 \mathrm{a}$ wise measure had provided for the statutory recognition of societies established by voluntary enterprise to aid discharged prisoners, and afforded a stimulus to the formation of others. It was left to these societies to develop the modern principle that the object of prison discipline is not only the punishment of crime but mainly the reformation of the offender.

Not less important than the reform of the criminal law in its methods of punishment was the reorganisation of the agents employed to protect the community by the detection of crime. In $1826 \mathrm{Sir}$ Robert Peel constituted the Metropolitan Police, abolishing local administration in the metropolis outside the limits of the city of London, and placing the control of the new force in the hands of the Secretary of State. Counties and boroughs followed suit, and, while reserving the right of control, remodelled their police on the administrative principles of Sir Robert's Act.

Logically inseparable from the reform of the criminal law was a revision of the law affecting the Churches which had been in turn the instigators and the victims of its severest penalties. After the Revolution of 1688 the maintenance of the Protestant settlement and dynasty was the essential principle of English policy, and conformity to the Church of England was held to be the test of qualification for all those vantage points of power of 


\section{THE BROAD STONE OF EMPIRE}

which James the Second had availed himself to subvert the liberties of Englishmen. The legislative machinery of penalties and disabilities was ready to their hand. It was a felony for a Roman Catholic to keep a school, a capital crime to celebrate marriage between a Papist and a Protestant. Catholics were denied admission to the bar, and any lawyer marrying a Catholic was held to be a Papist. In addition, there were the disabilities imposed by the Corporation and Test Acts which applied equally to Protestant Dissenters. The Corporation Act of 166 I required members of Corporations to receive the Sacrament after the manner of the Church of England; and the Test Acts of 1673 and 1685 extended the obligation to all magistrates and holders of public offices civil and military, and required them to take the oaths of allegiance and supremacy, and to abjure the belief in transubstantiation.

The Revolution of 1688 was immediately followed by the Toleration Act of r689, which relieved Protestant Dissenters from the penalties incurred by absenting themselves from church, and holding unlawful conventicles, on their taking an oath of allegiance and supremacy and making a declaration against popery. But it still left in force the provisions of the Corporation and Test Acts. It was not till the year ${ }_{1} 828$ that Lord John Russell brought forward and carried a Bill for the repeal of those Acts, laying down this broad principle: "Statutes imposing penalties and restrictions on account of religions can be justified on no other ground than that of necessity. When that ground 
is taken away, the Acts remain in all their naked deformity of principle, and that principle is religious persecution."

Mean while it was not till the close of the eighteenth century that Catholics in England and Ireland succeeded in obtaining relief from the most vexatious of the disabilities imposed on them under a system of oppression believed to be the only security for the Protestant Settlement of 1688. Hallam has declared that this system was contained "In a series of laws during the reign of William and Anne which have scarce a parallel in European history, unless it be that of the Protestants in France after the revocation of the Edict of Nantes," adding that "to have exterminated the Catholics by the sword, or expelled them like the Moriscoes of Spain, would have been little more repugnant to justice and humanity, but incomparably more politic."

The broad principle declared by Lord John Russell in his speech on the repeal of the Corporation and Test Acts, and the general trend of public opinion that had led up to that measure, made it evident to far-seeing men that the time was approaching when the friends of civil and religious liberty, who had been foremost in the exclusion of the Catholics as dangerous to those liberties, might consistently with their principles remove exceptional restraints no longer necessary. In I 829 the law of action and reaction received a memorable illustration. In that year the Duke of Wellington, who had led the opposition to the Catholic claims as inconsistent with the security of the Empire, yielded to the conviction that security would be imperilled 
by further resistance. The Catholic Emancipation Bill received the Royal assent on April I 3 th, I829. Within a few days the first Catholic peers had taken their seats in the House of Lords, and within a few weeks Catholic members had taken their seats in the House of Commons for constituencies in England and Ireland. The story of the further emancipation of Catholics from disabilities that survived the Act need not be continued. I am dealing with the imperial principle of religious toleration which was to be a foundation of faith in the policy of the Victorian era. It was soon to be signally illustrated in the emancipation of the Jews after three hundred years of absolute exclusion from England, and many centuries of endeavour to extirpate them, as recorded by Lord Beaconsfield in his biography of Lord George Bentinck: "The attempt to extirpate them has been made under the most favourable auspices and on the largest scale; the most considerable means that man could command have been pertinaciously applied to this object for the longest period of recorded time. Egyptian Pharaohs, Assyrian kings, Roman emperors, Scandinavian crusaders, Gothic princes and holy inquisitors, have alike devoted their energies to the fulfilment of this common purpose. Expatriation, exile, captivity, confiscation, torture on the most ingenious and massacre on the most extensive scale,-a curious system of degrading customs and debasing laws which would have broken the heart of any other people, have been tried, and in vain." It is needless to trace the steps by which the Jews were gradually freed from disqualification by enactments 
opposed at every stage with a violence, and at times a malignity, that seems incredible in view of the position they now hold in the Empire.

We have seen that during the Middle Ages it was education, and education alone, that opened to all classes the door of access to the high places of emolument and dignity, while to the Catholic Church alone was entrusted the use of this instrument of social equality. And we have marked the reversal of policy which resulted in making the use of the instrument by the Catholic Church a felony. The logical consequence of the policy of religious toleration was to associate all religious denominations in the equal use of that instrument under the supremacy of the State. No policy has ever been at once more approved in theory and more difficult in application. Nor, I think, has the difficulty of reconciling theory with practice been better expressed than by Cobden. Ever since 1835 , on his return from a visit to the United States, Cobden had preached the doctrine of education as the sole title to constitutional franchise, the sole guardian of political liberty, the sole qualification for self-government. And his visits to the Continent of Europe had confirmed him in the constantly asserted belief that the English were the least educated of any Protestant community in the world. After fifteen years endeavour to find a scheme which might reconcile the principle of secular instruction with the exigencies of the demand of the Churches for doctrinal instruction, he declared himself, in I $85 \mathrm{I}$, at Manchester in these terms :

"I must confess, I have always been so impressed with the difficulties of this question, that if a proposal 
had been made by which it was intended to give an improved education to the people, coupled with conditions ten times as objectionable as those we have lately had proposed to us, I do not think I could have found it in my heart to have offered any very strong opposition. I have really passed beyond the time in which I can offer any opposition to any scheme whatever, come from whatever party it may, which proposes to give the mass of the people of this country a better education than they now receive. I will say more,- - that in joining the system of secular education, I have not taken up the plan from any original love for a system of education which either separates itself from religion, or which sets up some peculiar and novel model of a system which shall be different from anything which has preceded it in this country. I confess that for fifteen years my efforts in education, and my hopes of success in establishing a system of national education, have always been associated with the idea of coupling the education of this country with the religious communities which exist. But I have found, after trying it, as I think, in every possible shape, such insuperable difficulties in consequence of the religious discordances of this country,that I have taken refuge in this, which has been called the remote haven of refuge for the Educationists,-the secular system-in sheer despair of carrying out any system in connection with religion. I should, therefore, be a hypocrite, if I were to say I have any particular repugnance to a system of education coupled with religious instruction. But there is no one in this room, or in the country, that 
can have a stronger conviction than I have of the utter hopelessness of ever attempting to unite the religious bodies of this country in any system of education; so that I can hardly bring myself even to give a serious consideration to the plan that has been now brought forward by gentlemen in this city, and who have brought it forward, no doubt, with the best possible intentions, and who have only to persevere in order to find what I have found, for the last fifteen years, - the hopelessness of the task. For what is it those gentlemen have now proposed to do? Is there any novelty in it? Why, it is precisely what Parliament, and the Government, and the Committee of Privy Council, have been attempting to do now for a great number of years, - that is, to give a system of education to the country which shall comprise religious instruction, and which shall call upon the people of this country to subscribe, through taxation or rates, for the general religious as well as secular education of the country."

And again, a few months later, in advocating the same principle:

"I believe, if we once get a system of free schools, the spirit of a free-school system will very soon possess itself of the minds of the people; that it will be found here, what it has been found in Ireland, under a far severer pressure and test than it ever can have in this country: it is superior in its strength to almost all other influences; and I believe, if we once establish a system of free schools supported by rates in this country, it won't be long that you who pay rates here in Manchester will allow either Roman Catholics or Jews to be excluded from the 


\section{THE BROAD STONE OF EMPIRE}

benefits of those rates." And then, after dwelling on the urgent need of a wider intelligence among the people, he reiterated his declaration that "We are the worst educated people of any Protestant community in any part of the earth," challenging denial by personal investigation.

I do not propose to discuss the sectarian diffculties, which are hardly less embarrassing at the present day than they were in Cobden's time. It cannot be said that any satisfactory solution of the problem was found within the period I am dealing with. But the passage of the Reform Act was quickly followed by a far-reaching measure. In I 834 the Government first obtained from Parliament a grant of $£ 20,000$ in aid of education. It was distributed through the National School Association, an agency in strict connection with the Church of England, and the British and Foreign School Society which admitted children of all Christian denominations without imposing on them sectarian teaching. In I 839 the grant was increased to $£ 30,000$, and the Committee of the Privy Council on Education constituted for its distribution. It was not till i 870 that the distribution of the grant, on the impartial principle of payment by results, was included in the Act of that year, which has served as a basis of the educational system in every part of the Empire under the direct control of the Home Government, alike in India and in the Crown colonies. In the meantime, however, stages in educational progress were marked by the establishment of the Ragged School Union in ${ }_{1} S_{54}$, the Industrial Schools Act in 1857 , the examination of Middle 
Class Schools by the Universities in 1858 , the College and Public School Commission's Report in I 864, and the introduction of the Conscience Clause by the Committee of Council on Education in the same year.

The educational problems of the period involved two questions of main importance,- the agencies to be employed and the range of operation. The potential agencies were two,- the State and private enterprise; and the plan adopted was to associate with the service of the State all who were willing to co-operate for a known object, on a definite plan, without waste of strength or resources; in other words, to make private enterprise an auxiliary of the State rather than an obstacle in the way of Government. As regards the range of operation, the policy adopted was based on the principle that there can, in the long run, be no permanent divorce between the masses that produce and the class that is to administer the revenue of the country. Consequently, the range of operation had to be adequate to qualify the community, without distinction of creed or class, for a full share of work in the development of the natural resources of the land, in the application of science to industrial processes, and in the transactions of commerce; as well as to qualify them for the learned professions, and the service of the State. As the agencies were to be open to all, so was the range of study to be open to all. Nor was the bearing of secular as well as religious education on the national character overlooked. As early as $\mathrm{I} 807 \mathrm{Mr}$. Whitbread had called on the country to support a plan of national education, declaring 


\section{THE BROAD STONE OF EMPIRE}

that nothing could afford greater stability to popular government than the education of the people. His plan included a scheme by which the savings of the poor might be invested in a great national bank. "In the adoption of this system," he said, "I foresee an enlightened peasantry, frugal, sober, industrious, orderly and contented, because they are acquainted with the true value of frugality, sobriety, industry and order, and because every man knows the worth of that which he is called upon to defend." Whitbread was ridiculed as a benevolent visionary, but in 1817 the system of savings-banks was started with such success that in 1844 there existed 577 banks with over a million depositors and an aggregate of property amounting to over $£ 30,000,000$.

Nor was it long before the intimate connection between education, frugality, and sobriety began to be felt. About the year 1825 there originated in the United Kingdom and America a great movement directed to the abatement of intemperance, and it may safely be said that no other social propaganda of the nineteenth century was carried on with more unselfish devotion and more indefatigable labour. In the United Kingdom the early days of the movement are most closely associated with the work of Father Mathew in Ireland. Illicit stills were closed by dozens; grog-shops were changed into coffee-kitchens; men put their heads together to discuss the interests and the destiny of Ireland, instead of breaking them in drunken frays. In the very first year there was a large increase in the numbers of depositors in savings-banks; at the 
end of two years, when the number who had taken the pledge exceeded 2,500,000, not one of that number had appeared before judge or jury.

Intimately connected with the question of education as an engine of social progress is the question of the health of the people. "Take," said Cobden, in a speech on education, "take the question of sanitary reform. Why do people live in bad cellars, surrounded by filth and disease? You may say it is their poverty, but their poverty comes as much from their ignorance as their vices; and their vices often spring from their ignorance. The great mass of the people don't know what the sanitary laws are; they don't know that ventilation is good for health; they don't know that the miasma of an unscavenged street or impure alley is productive of cholera and disease. If they did know these things, people would take care they inhabited better houses; and if people were only more careful of their means they might get into better houses."

Broadly speaking, the health of the people depends on measures of two kinds, - territorial sanitation and personal treatment. About i 832 Dr. Southwood Smith commenced an agitation on the subject of public health, and subsequently published numerous sanitary reports for the information of the Government. The movement was in time followed by legislative enactments of which the principal were a series of Nuisance Removal Acts (I $845-60$ ), the Public Health Acts of 1845 and 1855 , and the Common Lodging Houses Acts of 1851 and 1853 . Coincidently the question of reform in the education of the medical profession was dealt with by various 


\section{THE BROAD STONE OF EMPIRE}

measures, among which may be noticed the Acts of 1815 and 1825 , regulating and extending the practice of the London Apothecaries' Company, and the Acts of 1858 and 1860 , passed to regulate the qualifications of practitioners in medicine and surgery, and establishing the General Council of Medical Education and Registration.

Associated with these measures were the Factory Act of 1833 and subsequent legislation regulating the employment of children in factories, and the Poor Law Act of 1834 , followed by a long series of enactments to alleviate the condition of the unemployed and houseless poor. The abuses which the Poor Law Act was designed to remedy had long become a scandal and a prominent feature in criticisms and caricatures of English society. While the suffering but deserving poor were abandoned to starvation, insult, or cruelty, the poor-rate had become public loot. To obtain their share of the plunder, the brutal bullied the guardians, the profligate carried their bastards to be fed,--so tempting was the allowance paid for infants, that in many districts it was scarcely possible to find a virtuous girl,- the idle folded their arms and waited; boys and girls married upon it; prostitutes and thieves extorted it by intimidation; country justices lavished it for popularity, and guardians for convenience. I do not propose to discuss the provisions of the Poor Law of 1834 , but I may observe that it was in a sense a negative measure to remedy scandalous abuses; it anticipated that constructive measures would follow an improved condition of the people resulting from education. In short, it was to educa- 
tion that Parliament looked for the reconstruction of society.

It is difficult even for those whose lives have covered the period of the Victorian era to realise the severity of the struggle by which the measures of political and social reform I have traced were achieved. It was a revolution only just falling short of civil war. And yet all those measures were but means to an end,- - the end being to secure for every working man in the United Kingdom an appropriate, useful, and honourable place in the community. The relations of the workman to his master had passed through two stages. In the first stage, the relation was that of possession,- - the workman was the slave or chattel of his owner; the feudal relation of the next stage was one of recognised dependence and admitted vassalage. The relation was now to be one of contract between two independent parties. The adjustment of interests in the new relation has given rise to a new phase of conflict, but underlying the conflict there has always been a recognition of the fact that the parties are mutually indispensable. The reforms I have traced had secured for the workman liberty of thought and action, and placed the instrument of education at his disposal. But his emancipation had of necessity withdrawn him from agencies of protection on which he had been able to rely to guide his conscience and guard his life. He was now thrown on his own resources.

It became the business of the Parliament which had secured his liberty to enable him to profit by it. Adam Smith had laid down this proposition: "The property which every man has in his own labour, as 


\section{THE BROAD STONE OF EMPIRE}

it is the original foundation of all property, so it is the most sacred and inviolable. The patrimony of a poor man lies in the strength and dexterity of his hands, and to hinder him from employing this strength and dexterity in what manner he thinks proper without injury to his neighbour, is a plain violation of the most sacred property. It is a manifest encroachment upon the just liberty both of the workman and of those who might be disposed to employ him." The party of Reform, accepting this proposition, had now to engage in a formidable struggle to give it practical application. The measures they introduced into Parliament had two main objects; first, to remove all restrictions that tended to increase the cost of living, or to limit the area of employment; and, secondly, to enlarge the area of employment by adding fresh areas of supply and demand. The agency by which these objects were to be secured was a policy of Free Trade.

The evolution of the policies of Free Trade, Protection, and Prohibition has been briefly described. It was not long before the law of action and reaction followed the Prohibition policy of 1815 . In 1821,1824 , and 1825 , the Navigation Laws were relaxed against the strongest opposition of the shipping interest. In 1824 the duties on wool, in 1826 the duties on silk, in 1828 the duties on corn, were reduced against equally violent opposition. In I $8_{4}$ I Cobden and Bright commenced the agitation for the repeal of the Corn Laws. In 1842 Peel effected a great relaxation of the protective system, exempting from duty all raw materials, and 
exempting or reducing the duties on 750 articles. In 1846 he carried the repeal of the Corn Laws. It remained for Mr. Gladstone to push the principles of Free Trade to their extremest limit. By these measures it was hoped to retain for the joint benefit of British capital and labour an area of industry and commerce, extended by the use of scientific methods and steam-power applied to manufactures, railways, and navigation, and by the development of associated and subsidiary interests.

It is unnecessary for me to discuss the arguments by which the policy of Free Trade was supported or resisted; but in view of the present controversy, I may recall a main argument in its favour arising out of the consequences of the Revolutionary War which had produced the same results on the Continent of Europe as in the United Kingdom. The following extract from a pamphlet published by Cobden in I 835 , has an especial interest for us, though it does not seem to have been included in any recent edition of his works. In urging the vital necessity of keeping aloof from any complications that might involve Europe in war, he wrote:

"Were a war once to break forth over the continent of Europe, and were we to stand aloof from the conflict, our commerce and manufactures, instead of receiving injury in any quarter, would be thereby benefited; for besides the well-known facilities which a state of warfare would give to the smuggler for supplying those very belligerents themselves with the products of our labour, it would at the same time put an end to the competition which we now sustain in other parts of the world, from our manu- 


\section{THE BROAD STONE OF EMPIRE}

facturing rivals of Europe. Germany, France, Switzerland, and Belgium, and indeed almost every nation of the continent, for whose independence and existence we fought so long and arduously, have profited by the peace, to exclude our fabrics from their markets, and in mistaken policy, borrowed from our own restrictive code, to raise up, at great sacrifices of national wealth, a manufacturing industry for themselves.

"Thus, we find that, at this moment, Prussia is completing a wall of tariffs, which she has been sedulously constructing for many years, and which will, more effectually than did Napoleon, exclude us from the German market-Prussia, for whom we bled, and for whose subsidies we are still taxed: Austria, another of our costly allies, whose disasters our most renowned statesman ${ }^{1}$ would not outliveAustria has, ever since the peace, sealed her territory against our merchandise. Naples,-that unworthy protégé, in behalf of whose court England's greatest hero ${ }^{2}$ sullied his otherwise untarnished fame-Naples repays us with an impost of cent. per cent. upon our manufactures; while France has, since Napoleon's fall, been a less profitable customer to England than she was during the time of his extremest enmity towards this country."

Briefly, the line of argument was that Prussia had been compelled by the Protectionist and Prohibition policy of the United Kingdom to build up a retaliatory wall of tariffs, and to promote at a great sacrifice a manufacturing industry to compete with British trade; that Prussia's example was being followed by

${ }^{1}$ Pitt and Ulm.

${ }^{2}$ Nelson. 
the rest of Europe; and that the substitution of a policy of Free Trade by the United Kingdom would be followed by the removal of the tariff walls, and would arrest a competitive rivalry that threatened to reduce to narrow limits the area of employment, by restricting the area of supply and demand.

I shall have something to say hereafter as to the application of the policy to changed conditions arising out of the disappointment of the expectations on which this argument was based. I am concerned here only with the influence of this argument on the colonial policy of the day. But this must form the subject of another chapter. 


\section{CHAPTER IV}

\section{OUR COLONIAL POLICY}

$$
\text { I } 8 \text { I 5-I } 868
$$

1. NORTH AMERICA. 2. SOUTH AFRICA. 3. AUSTRALIA AND NEW ZEALAND. 4. INDIA. 5. TROPICAL COLONIES

THE cosmic law of action and reaction which produces the swing of the pendulum has been signally illustrated in the three stages of the evolution of our colonial policy. During the first our colonies were held to be politically and commercially necessary, during the next to be politically mischievous and commercially useless; now they have again come to be considered of the first importance both in politics and commerce. Every step in the expansion of England was guided by some motive of political or conmercial necessity. The policy of Pitt was based on the belief that the fate of Europe must be decided on the continent of America. The islands of the Caribbean Sea have been the keys of international strategy since the days of Charles the Fifth. Captain Mahan has declared the Caribbean Sea to have been the very domain of sea-power, and its group of island fortresses the greatest nerve-centre in the whole body of European civilisation. It was in the 
Caribbean Sea, by fleets he had never seen, that Napoleon's power was shattered and the British Empire established in the secure environment of naval supremacy. "England," said Napoleon at St. Helena, "can never be a Continental Power, and in the attempt must be ruined: let her maintain the empire of the seas, and she may send her ambassadors to the Courts of Europe and demand what she pleases." The words express the imperial sentiment of the Victorian era so exactly that it is not easy for the younger generation to understand a policy which could hold the colonies to be not only useless but mischievous. Peace, Retrenchment, and Reform were to work out the economic salvation of England and to reconstruct society, in accordance with the principles of political and social reform I have already explained, and with the policy of Free Trade.

The very name of Free Trade implies reciprocity, and I have indicated the grounds that led its advocates to believe that it would be universally adopted. In this faith, relying on the acknowledged naval and industrial supremacy of England, they took it for granted that she was and would remain ManufacturerGeneral to the Universe, and that all the world would compete in supplying her with cheap food and raw material, and in favouring the admission of her manufactured articles into their free ports. Consistently with this belief, with all the world to be open, as they hoped, to the consumer and producer, they advocated a cosmopolitan system of commerce without distinction of home, colonial, or foreign origin. They sought, therefore, to be relieved of the 


\section{THE BROAD STONE OF EMPIRE}

embarrassment and expense of colonial associations, and looked forward with complacency, sometimes with eagerness, to the gradual separation of the colonies from the mother country. This policy came to be known in the political slang of the day as "letting go the painter."

The imperial sentiment of the last few years has concentrated its hostility to this policy in applying to its promoters the term Little Englanders; and writers on colonial history have collected a number of dicta by eminent statesmen, which, taken singly, seem to bring within the designation every statesman responsible for our colonial policy for half a century. And yet there was not one of these statesmen of the first rank, including Cobden, who did not, either by immediate reservation or by subsequent profession, at some time or other express himself in terms consistent with what we should at the present day consider sound imperial judgment. The truth is that there was a good deal of justification at the time for the policy now condemned, and for the utterances it is the present fashion to treat with contemptuous ridicule. I propose to group our over-sea dominions according to their geographical position in America, Africa, Asia, and Australia, and indicate some of the principal causes that influenced the statesmen who held them to be politically mischievous. The question of their commercial utility will then be briefly discussed. It will be convenient, however, first to group some expressions of the general sentiment of the nation by representative writers.

The secession of our original colonies was very 
soon followed by a feeling that the responsibilities of colonial possessions were more certain than the advantages. As early as 1784 the intelligent traveller, Arthur Young, had formed the opinion that, "All transmarine or distant possessions are sources of weakness, and to renounce them would be wise"; and so late as I86I Sir George Cornewall Lewis, summing up the advantages and disadvantages of empire, wrote: "If a country possesses a dependency from which it derives no public revenue, no military or naval strength, no commercial advantages, or facilities for emigration, which it would not equally enjoy though the dependency were independent, and if, moreover, the dependency suffers the evils which are the almost inevitable consequences of its political condition, such a possession cannot justly be called glorious." In the following year he declared in Parliament: "I, for one, can only say that I look forward without apprehension and, I may add, without regret, to the time when Canada might become an independent State." At the same time John Stuart Mill had arrived at the same conclusion, and the policy of those now called Little Englanders was never more clearly and concisely stated than when he wrote:

"England is sufficient to her own protection without the Colonies, and would be in a much stronger as well as more dignified position if separated from them than when reduced to be a single member of an American, African, and Australian Confederation. Over and above the commerce which she might equally enjoy after separation, England derives little advantage, except 


\section{THE BROAD STONE OF EMPIRE}

in prestige, from her Dependencies; and the little she does derive is quite outweighed by the expense they cost her and the dissemination they necessitate of her naval and military force, which, in case of war, or any real apprehension of it, requires to be double or treble what would be needed for the defence of this country alone."

In Mrs. Fawcett's Life of Sir William Molesworth, it is stated that Cobden gave the policy its crudest expression when he said, referring to the Army and Navy, that "John Bull has for the next fifty years the task set him of cleansing his house from this stuff." The note annexed to this quotation has not helped me to verify it, though it seems to be generally accepted.

Sir William Molesworth's views will be dealt with later. Mr. Goldwin Smith's expectation and desire that Canada should cut herself adrift from England and become a part of the United States are well known. I will only add an expression of Viscount Morley's opinion in reviewing Seeley's Expansion of England: "What is the common bond that is to bring the Colonies into a Federal Union? . . . Is it possible to suppose that the Canadian lumberman and the Australian sheep-farmer will cheerfully become contributors to a Greater Britain fund ? . . . Is there any reason to suppose that South Africa would contribute towards the maintenance of cruisers? No, we may depend upon it that it would be a mandat imperatif on every federal delegate not to vote a penny for any war, or preparation for war, that might arise from the direct or indirect interests of any colony but his own." 
I pass on to a consideration of the particular causes, arising out of their internal circumstances and their environment, which made the colonies areas of possible political mischief.

\section{NORTH AMERICA}

In the year $\mathrm{I}_{37}$, a few weeks before the accession of the Sovereign whose name was to be associated with an era of imperial unity to which history has furnished no parallel, our relations to Canada were under discussion in the House of Commons, on the question of the union of Upper and Lower Canada. On March 8th, - I quote Viscount Morley"Mr. Gladstone, who had from his earliest days regarded our colonial connection as one of duty rather than as one of advantage, took a firm stand against pretensions in Canada to set their Assembly on an equal footing with the Imperial Parliament at home." And commenting on this, the biographer observes: "In their views of colonial policy, $\mathrm{Mr}$. Gladstone was in substantial accord with the radicals of the school of Cobden, Hume and Molesworth. $\mathrm{He}$ does not seem to have joined a reformation association founded by these eminent men among others in 1850 , but its principles coincided with his own:-local independence, an end of rule from Downing Street, the relief of the mother country from the whole expense of the local government of the colonies, save for defence from aggression by a foreign power." On April I 4 th, Mr. Roebuck, who rose to distinction as the representative of a group recognised as superior persons, said: "Whatever may be the course we pursue, 


\section{THE BROAD STONE OF EMPIRE}

the time must inevitably come when our American colonies will become independent Powers." Later in the same year the demands of the FrenchCanadian party led by Papineau were pressed to open rebellion. Sir William Molesworth went so far as to invoke disaster on the British arms: "Should a war take place, I must declare that I should more deplore success on the part of this country than defeat: and though as an English citizen, I could not but lament the disasters of my countrymen, still it would be to me a less poignant matter of regret than a success which would offer to the world the disastrous and disgraceful spectacle of a free and mighty nation succeeding by force of arms in putting down and tyrannising over a free though feebler community struggling in defence of its just rights. . . That our dominion in America should now be brought to a conclusion, I for one most sincerely desire, but I desire it should terminate in peace and friendship. Great would be the advantages of an amicable separation of the two countries, and great would be the honour this country would reap in consenting to such a step."

The causes of the rebellion which marked a distinct epoch in Canadian history were succinctly stated in Lord Durham's report, laid before Parliament in January, I 839 .

The troubles both in Lower and Upper Canada appeared to Lord Durham to be due to the absence of a working identity of will between the popular assemblies on the one side, and, on the other, the executive power supported by its nominees in the legislative councils. In Lower Canada there was 
also the difficulty arising from the presence of two races-one in a great numerical majority, French in origin and language, Roman Catholic in religion, mainly agricultural by occupation in the small farmer or peasant way, poorer and more content, less progressive, ambitious, and enterprising; the other British by origin, Protestant in religion, commercial, or farming on a large scale, far more energetic, restless, and enterprising, and richer. The two races were divided by race, language, religion, occupation, education, tastes, aims, and social differences. The English were irritated by the obstacles to the improvement of trade and commerce which were placed in their way by French jealousy; the French were irritated by the political and economic ascendancy of a minority.

The ascendancy which an unjust favouritism had contributed to give to the English race in the government and the legal profession, their own superior energy, skill, and capital secured to them in every branch of industry. They had developed the resources of the country; they had constructed or improved its means of communication; they had created its internal and foreign commerce. The entire wholesale and a large portion of the retail trade of the province, with the most profitable and flourishing farms, were in the hands of this numerical minority of the population.

The English looked on the French with contempt; the French, as the English economic conquest progressed, saw their rivals with "alarm, with jealousy, and finally with hatred." Intermarriages were rare; there was no combination for public objects of any 
kind, not even for those of charity. "The only public occasion," said Lord Durham, "on which they ever meet is in the jury-box, and they meet there only to the utter obstruction of justice."

Meanwhile, Lord John Russell in the House of Commons, on January 16 th, 1838 , in introducing a bill to suspend the liberties of Lower Canada in consequence of the rebellion, had made a speech in which the policy of the day found the clearest expression it has ever received. Referring to the question of the responsibility of the Executive to the Legislature, he said: "I stated that there was one place in which the power of the Executive could be thus entirely controlled, and this was at the seat of the Imperial Government. If the Sovereign of this country were to select those who had the confidence of the Crown, but who possessed none of the confidence of the House of Commons, there must be a speedy change in the administration, and the Constitution could only proceed in consequence of that change. But, in a colony, if the Executive Council are to be named according to the will of the Assembly, there is another question which arises, namely, what is to become of the orders given by the Imperial Government and the Governor of the colony..... With respect to trade, it has always been admitted that an Imperial Legislature has a right to compel a colony to receive the produce of the Mother Country, and a right to restrict that colony in its commerce with other nations."

At the same time, an alternative policy was presented with cautious balance. 
"I do believe that the possession of our Colonies tends materially to the prosperity of the Empire. On the preservation of our Colonies depends the continuance of our commercial marine, and on our commercial marine depends our naval power, and on our naval power mainly depends the strength and supremacy of our arms. ... Although I am not prepared to give immediate independence, this I will say, that, if the time were to come at which such an important change might be safely and advantageously made, I should by no means be indisposed to give the $1,400,000$ of our present fellow-subjects who are living in North America a participation in the perfect freedom enjoyed by the Mother Country. If it were a fit time, if circumstances of all kinds were such as to render such an arrangement desirable, I think that our Colonies might with propriety be severed from us, and formed into a separate and distinct State in alliance offensive and defensive with this country."

In 1840 Lord Ashburton, the negotiator of the treaty that settled the Maine Boundary question, a cause of political mischief, speaking with an unrivalled knowledge of our relations with America, declared in the House of Lords, that it was in his opinion useless to keep these colonies.

In May, I842, Sir Robert Peel, writing to Lord Aberdeen on the question of a Canadian Civil List, said :

"It would seem that we are to be involved in new controversies about the Civil List in Canada, and that squabbles on this subject between the Mother Country and the province are to be the instruments 


\section{I02 THE BROAD STONE OF EMPIRE}

by which the late constitutional settlement, and the union of the provinces, are to be disturbed.

"Now, if there is not a British party in the Canadas sufficient to put down these attempts at renewed conflicts, I for one should be very much disposed to hold high language.

"Let us keep Nova Scotia and New Brunswick; for their geographical position makes their sea-coast of great importance to us. But the connection of the Canadas against their will, may, without the cordial co-operation of the predominant party in Canada, be a very onerous one. The sooner we have a distinct understanding on that head, the better. The advantage of commercial intercourse is all on the side of the Colony, or at least is not in favour of the Mother Country. Why should we go on fighting not our own battle (I speak now of a civil battle) but theirs-in a minority in the Legislature, the progress of the contest widening daily old differences and begetting new ones?

"And above all, if the people are not cordially with us, why should we contract the tremendous obligation of having to defend, on a point of honour, their territory against American aggression?

"Let us fight to the last for the point of honour, if the people are with us. In that case we cannot abandon them. But if they are not with us, or if they will not cordially support and sustain those measures which we consider necessary for their good government and for the maintenance of a safe connection between them, let us have a friendly separation while there is yet time, rather than recommence a system of bickering and squabbling 
on petty points, the result of which will be increasing ill humour and alienation on their part, constant encouragement to American sympathisers, and ultimately the necessity of our vindicating British honour, with Canadian feeling adverse to us, the war at the door of the United States, and 3000 or 4000 miles from our shores."

In I 849 Lord Elgin, then Governor-General, called attention to an influence on the relations of Canada to the mother country, which has been of ever-increasing peril in our colonial history. Referring to the movement in favour of annexation to the United States, he wrote to Lord Grey on November Ioth, I849:

"Very much, as respects the result of this annexation movement, depends upon what you do at home. I cannot say what the effect may be if the British Government and press are lukewarm on the subject. The annexationists will take heart, but in a tenfold greater degree the friends of the connection will be discouraged. If it be admitted that separation must take place, sooner or later, the argument in favour of a present move seems almost irresistible. I am prepared to contend that with responsible government, fairly worked out with free trade, there is no reason why the colonial relation should not be indefinitely maintained. But look at my present difficulty, which may be increased beyond calculation, if indiscreet expressions be made use of during the present crisis. The English Government thought it necessary, in order to give moral support to their representative in Ireland, to assert in the most solemn manner that the Crown would never consent 
to the severance of the Union; although, according to the O'Connell doctrine, the allegiance to the Crown of the Irish was to be unimpaired notwithstanding such severance. But when I protest against Canadian projects for dismembering the empire, I am always told 'the most eminent statesmen in England have over and over again told us, that whenever we chose we might separate.' Why, then, blame us for discussing the subject ?"

In I 850 Lord John Russell made a speech on the colonies in which he reiterated the views he had expressed in 1837 , with the same cautious reserve in his peroration. In a letter to Earl Grey, Lord Elgin promptly pointed out the danger that necessarily arose from this declaration of policy.

“Lord John's speech on the colonies seems to have been eminently successful at home. It is calculated, too, I think, to do good in the colonies; but for one sentence, the introduction of which I deeply deplore-the sting in the tail! I much fear that when the liberal and enlightened sentiments, the enunciation of which by one so high in authority is so well calculated to make the colonists sensible of the advantages which they derive from their connection with Great Britain, shall have passed away from their memories, there will not be wanting those who will remind them that, on this solemn occasion, the Prime Minister of England, amid the plaudits of a full senate, declared that he looked forward to the day when the ties which he was endeavouring to render so easy and mutually advantageous would be severed. . . . Is it not hard upon us while we are labouring through good and evil 
report, to thwart the designs of those who would dismember the Empire, that our adversaries should be informed that the difference between them and the Prime Minister is only one of time? If the British Government has really come to the conclusion that we are a burden to be cast off whenever a favourable opportunity offers, surely we ought to be warned."

The revolutionary period of $1848-49$ and its consequences threatened an outbreak of the hostility between England and France which had for centuries been a fixed and abiding condition of our foreign relations. It was brought home to us that the colonies have ever been the chief influence in imperial implication in war. It is our being spread over all the world that brings us in contact at so many points with the responsibilities, jealousies, and cupidities of other nations and which makes war so wide a concern to us. It was at a time when a warpanic had taken hold of the nation, and prompted a demand for increased military and naval expenditure, that a motion for the reduction of colonial expenditure was introduced in the House of Commons. On April Ioth, I 85 I, Sir William Molesworth, speaking on the motion, called attention to a question which has always been the cause of irritation, the question of a contribution to the cost of the Imperial forces. He said:

"Every such war (with an external foe) is necessarily an Imperial war; the troops employed in it are employed for Imperial purposes, and consequently their expenses ought to be paid by the Imperial Government; though in certain cases it would not 
be unreasonable to expect that the colonies should assist the empire both with troops and money; and I feel convinced that if the Colonies were governed as they ought to be, they would gladly and willingly come to the aid of the Mother Country in any just and necessary war. They would do as the men of our old North America plantations did during a war with France, when they willingly bore a large portion of the burden of the contest with that monarchy and its Indian allies, and in every way proved themselves to be the hardy and generous sons of England."

It was not long before the peril of implication in war through disputes of colonial origin was brought home to us. The history of Newfoundland has been for centuries a record of rivalries and feuds between the English and French fishermen. Early in $185^{2}$ Sir Henry Taylor, Permanent Secretary for the Colonies, wrote to Earl Grey:

"I cannot but regard the North American Provinces as a most dangerous possession for this country, either as likely to breed a war with the United States, or to make a war otherwise generated more grievous and disastrous. I do not suppose the provinces to be useless to us at present, but I regard any present uses not obtainable from them as independent nations as no more than dust in the balance compared with the evil contingencies." A little later, in June, Earl Grey resigned and was succeeded by Sir John Pakington as Colonial Secretary. The friction between the English and French fishermen had by this time taken an acute form and involved us in a trilateral dispute with France and the United 
States. In the course of the controversy, Disraeli, who had become Chancellor of the Exchequer, made use of an expression which may be said to have hung like a millstone round his neck for years. In August, in a letter to the Foreign Minister, Lord Malmesbury, he wrote:

"The Fisheries affair is a bad business. Pakington's circular is not written with a thorough knowledge of the circumstances. He is out of his depth, more than three marine miles from shore. These wretched Colonies will all be independent too in a few years, and are a millstone round our necks. If I were you, I would push matters with Filmore, who has no interest to pander to the people like Webster, and make an honourable and speedy settlement."

In September, Lord Derby, the Prime Minister, wrote to Lord Malmesbury from Balmoral :

"We must hold very temperate, but very firm language: and assuredly, though God forbid it should come to that, I am prepared to fight for our undoubted rights, rather than yield to a spirit of democratic encroachment, which if not steadily resisted, will have no limits to its demands. But on this account it is doubly important that we should come to an early understanding on the same Fishery question with our French neighbours."

In 1856 another source of difficulty emerged, and five supplementary regiments were sent to Canada in anticipation of differences with the United States about our recruiting among them. Having scattered our own troops about the colonies we had made a fresh enemy in an "attempt to hire foreigners to take their place," and then had to increase the 


\section{IO8 THE BROAD STONE OF EMPIRE}

colonial detachments to confront the new enemy. This led to the appointment of a select Committee on Colonial Military Expenditure. The conclusions of the Committee, who reported to Parliament in 1859 , were summed up by Sir Charles Adderley (afterwards Lord Norton) in a recommendation, "That every part of the Empire should raise its own means of defence at home, and at the sound of danger all should be ready to rally round the threatened point, the ocean being our proper medium of national inter-communication, and every enemy being made aware that on his temporary success in any quarter, the vengeance of the whole Empire waits." For fifty years the question of giving practical effect to this recommendation has been agitated, and is still a subject of controversy. It had a constant influence on the policy of the early Victorian era. Its practical bearing on our relations with Canada was soon to be realised in the incident of the Trent affair which quickly followed the outbreak of civil war in the United States, and in the whole period of strained relations that followed.

The war had been preceded by symptoms of filibustering propensities in the United States, and in June, I86I, the garrison in Canada was considerably increased. Then came the Trent affair, and large reinforcements were sent across the Atlantic in the depth of winter until our forces amounted to 12,000 men. Although the Trent affair was a direct insult to the British flag, it was admitted that Canada was the ultimate object of the insult. As The Times declared: "If Canada had not been a British possession there would have been 
no reviling of England, no warlike demonstrations against England, and no outrages committed on the English flag." The Canadians welcomed our forces, but when their Government proposed that they should themselves arm in their own defence, they rejected the proposal, ousted the Ministry, and repeated the refusal to arm when again called upon by the succeeding Ministry.

It was in the singular position thus created that the Duke of Newcastle, Colonial Secretary during this peril of the Empire, declared that he "should see a dissolution of the bond between the Mother Country and Canada with the greatest pleasure." The Duke of Newcastle retired from his office in April, s 864. A few weeks previously Sir Henry Taylor, in an official minute on the subject of Imperial Defences, had addressed him in these terms :

"As to the American provinces, I have long held, and have often expressed, the opinion that they are a sort of damnosa hereditas, and when your Grace and the Prince of Wales were employing yourselves so successfully in conciliating the colonists, I thought that you were drawing closer ties which might better be slackened if there were any chance of their slipping away altogether. I think that a policy which has regard to a not very far-off future should prepare facilities and propensities for separation; and I therefore agree entirely in Sir Charles Elliot's preference of a local and indigenous military force. So long as there shall be a single imperial battalion in the provinces, the whole imperial army and exchequer, and the honour of the crown, will be 


\section{IIO THE BROAD STONE OF EMPIRE}

committed to its support under difficulties : and circumstances may arise in which a large proportion of the imperial army and treasure will not be more than enough. This is what I fear. As to the current expenses of garrisons during peace, it is comparatively unimportant, as a mere matter of finance, what portion of them shall be borne by the provinces and this country respectively; but viewed as a part of a system and an implicit pledge, the future contingencies involved seem to me most formidable. In my estimation, the worst conse. quence of the late dispute with the United States has been that of involving this country and its North American provinces in closer relations and a common cause.

"I should desire to throw the current military expenditure upon the colonists, as tending: by connecting self-protection with self-government, to detach the Colonies and promote their independence and segregation at an earlier day, and thereby to withdraw this country in time from great contingent dangers. If there be any motives which should plead for a prolonged connection, it appears to me that they are of a cosmopolitan and philanthropic nature, and not such as grow out of the interests of this country, though there may be no doubt some minor English interests which are the better for the connection. There are national obligations also to be regarded, and some self-sacrifice is required of this country for a time. All that I would advocate is a preparatory policy, loosening obligations, and treating the repudiation by the colonists of legislative and executive dependence as naturally carrying 
with it some modification of the absolute right to be protected. As to prestige, I think it belongs to real power, and not to a merely apparent dominion by which real power is impaired."

On March 2oth, I865, Cobden, in anticipation of the projected confederation of the British North American colonies, wrote a letter to Colonel Cole in which he said:

"I cannot see what substantial interest the British people can have in the connexion, to compensate them for guaranteeing three or four millions of North Americans living in Canada, etc., against another community of Americans living in their neighbourhood. We are told indeed of the 'loyalty' of the Canadians; but this is an ironical term to apply to people who neither pay our taxes nor obey our laws, nor hold themselves liable to fight our battles, who would repudiate our right to the sovereignty over an acre of their territory, and who claim the right of imposing their own customs duties, even to the exclusion of our manufactures. We are two peoples to all intents and purposes, and it is a perilous delusion to both parties to attempt to keep up a sham connexion and dependence which will snap asunder if it should ever be put to the strain of stern reality. ... In my opinion it is for the interest of both that we should as speedily as possible sever the political thread by which we are as communities connected, and leave the individuals on both sides to cultivate the relations of commerce and friendly intercourse as with other nations. I have felt an interest in this confederation scheme, because I thought it was a step in the direction of 


\section{2 THE BROAD STONE OF EMPIRE}

an amicable separation. I am afraid from the last telegrams that there may be some difficulty either in your province or in Lower Canada, in carrying out the project. Whatever may be the wish of the colonies will meet with the concurrence of our Government and Parliament. We have recognised their right to control their own fate, even to the point of asserting their independence whenever they think fit, and which we know to be only a question of time. All this makes our present responsible position towards them truly one-sided and ridiculous."

Towards the close of the period with which I am dealing, in 1867 , when the guarantee of the Canadian Railway was proposed in Parliament, Mr. Cave, the member for Barnstaple, remarked that, "Instead of giving $£ 3,000,000$ with a view of separating Canada from the United States, it would be more sensible, and more patriotic, to give $£ 10,000,000$ in order to unite them."

It will be seen that the elements of political mischief in Canada were of two sources,-its relations to the British Government and its relations to foreign Governments. Looking back on the past in the light of subsequent events, it is easy to see that in its relations to the British Government the main issues were again two. First, was the relation of the British Government to the colonial Government to be one of responsibility for its internal and foreign affairs, associated with an adequate measure of control? Or was the control to be placed in the hands of the colonial Government, and the burden of responsibility for its exercise to be borne by 
British forces and the British exchequer? The claim of the British Government was that it should retain an adequate control through the subordination, in the last resort, of the colonial Legislature to the British Parliament through the agency of an Executive responsible to Parliament. But this issue was complicated by another. In the event of the British Government consenting to allow Canada complete control over its internal affairs, was that control to be exercised by the colonists of British or of French origin? These issues gave rise to the use of terms which played a considerable part in the colonial controversies of the period,- $\mathrm{Mr}$. Mothercountry and the British Party. Mr. Mothercountry was the term applied to the Colonial Office and to the policy of maintaining British control with a view to safeguard all British interests, financial and commercial. The term British Party was applied to the colonists of British origin who desired to secure the ascendancy of British interests with or without the control of the British Parliament. It may be well to note, in passing, that the recommendations of Lord Durham's report were, from first to last, designed to establish a self-governing colony under British ascendancy.

The other main element of political mischief in Canada arose out of its foreign relations, and of this enough has already been said.

\section{SOUTH AFRICA}

The elements of political mischief in our possessions in South Africa included the groups found in Canada, with a difference. In Canada the British 


\section{THE BROAD STONE OF EMPIRE}

and French parties were separated by race and the fundamental religious distinction between the principles of the Catholic and Protestant Churches. In South Africa the racial differences between British and Dutch were exasperated by the distinctive policy of the British and Dutch Protestant Churches in respect of the relations of the European colonists to the native community. Insomuch as it was essentially a question of the relation of the governing to the working class, it was a question intimately associated with the policy I have described as the basis of the reconstruction of social relations in the United Kingdom, and which asserted itself as a main factor of imperial policy in the abolition of slavery. This policy found its complete and perfect expression in the Proclamation of Queen Victoria to the Princes and Peoples of India in the year 1858 , in the declaration that, "No native shall, by reason only of his religion, place of birth, descent, colour, or any of these things, be disabled from holding any place, office, or employment, under the Government." In the very same year the Dutch policy found its complete expression in the Grondzvet or fundamental law of the Dutch South African Republic that, "The people will suffer no equality of whites and blacks, either in State or in Church." The British policy had been declared in South Africa at a much earlier date. Since the passing of the Fiftieth Ordinance of the Cape Legislature in 1828 , it had been the rule that there should be no colour disabilities in the Constitution, while in 1842 the granting of a Constitution to Natal was made conditionally on the acceptance by 
the Volksraad of a Proclamation by Queen Victoria in these terms: "There shall not in the eye of the law be any distinction of persons, or disqualification of colour, origin, language or creed; but the protection of the law in letter and in substance shall be extended to all alike." ${ }^{1}$ The Proclamation was published by the Governor on May I 2 th, and on August 8th the conditions contained in it were formally agreed to and accepted.

In 1833 the abolition of slavery, without compensation, had exasperated the Boers, and this was immediately followed by the abolition of the Dutch commando system of self-defence against the native tribes. From that time to this, in racial and religious distinctions have been found elements of political mischief that have made our possessions in South Africa the most perilous of our dominions. But the Colonial Office thought proper to add an additional element which for a time united British and Boers in the bond of resistance to a common foe. In ${ }^{8} 8_{37}$ a Committee of the House of Commons was appointed to enquire into the subject of transportation. Sir William Molesworth, who was Chairman of the Committee, some years later declared in Parliament that Colonial Office ideas of colonisation consisted almost exclusively in shovelling out of Europe its convicts and paupers, and that by our system of transportation we were converting our Colonial Empire into the moral dung-heap of Great Britain. One of the first acts of the United States, after the Declaration of Independence was a refusal to be made a deposi- 


\section{I16 THE BROAD STONE OF EMPIRE}

tory of British convicts; and as a result of the Committee's report, it was decided by the Colonial Office that the South African and Australian colonies, with the exception of Van Diemen's Land, should not be forced to receive convicts without their consent. Nevertheless, in 1849 , a shipload of convicts was sent to the Cape in spite of the most energetic protests and petitions by the whole body of white inhabitants. The convicts were not allowed to land, and, when the resistance of the colonists was carried to threats of rebellion, the attempt was abandoned. The only result of this eccentric venture was, as I have said, to unite the colonists for the time against what Sir William Molesworth called "The imbecile and mischievous administration of their affairs by the Colonial Office." But this episode was soon forgotten in the exigencies of the Kaffir wars that were the inevitable result of colonial expansion. The native tribes were pressed southwards from the north by hordes of warlike barbarians, while they were pressed northwards from the south by the policy of expansion by Dutch methods. Sir William Molesworth thus described the Dutch methods and the working of the commando system: "When the cattle of the Dutch were stolen, they assembled under their captains, followed the traces of their property, seized it or its equivalent wherever they found it, and righted themselves with a strong hand. In these excursions the Boer drew no distinction between the prowling and marauding savage and the beast of prey, but shot down with equal zest the cattle-stealing lion or Kaffir, and 
slew the bushman as a hideous, noxious reptile." Under pressure of friends of the aborigines in England the Colonial Office felt bound to protect the native tribes, and in 1836 an Act was passed placing all natives as far as the $25^{\text {th }}$ degree of latitude under British protection. In accordance with what has become a law of imperial expansion, the protectorate was soon followed by annexation, and by a proclamation of the Governor of the Cape "another worthless kingdom was added to our South African empire."

The story of the following years is the record of an attempt to reconcile two inconsistent and incompatible policies, the British policy, which had laid the foundation of our empire in Asia, of governing the native through the agency of his own chiefs and headmen under British supervision, and the policy of the Dutch, submission at sight or death. The attempt to reconcile these policies, and at the same time to reconcile the clamour of the British Parliament with the protests of the colonists, who were between the hammer and the anvil, was the cause of constant vacillation. Sir George Grey, undoubtedly the greatest administrator South Africa has known, was to a singular degree the victim of this pusillanimity on the part of the Colonial Office. When Sir George was recalled in I 859 , he defended himself in these terms: "With regard to any necessity which might exist for my removal on the ground of not holding the same views upon essential points of policy as Her Majesty's Government hold, I can only make the general remark that during the five years which have elapsed since I 


\section{THE BROAD STONE OF EMPIRE}

was appointed to my present office, there have been at least seven Secretaries of State for the Colonial Department each of whom held different views upon some important points of policy connected with this country." On his return to England the policy which led to his recall had been already reversed in consequence of a change of Government, and he was reinstated.

In the meantime, however, the consequences of expansion and annexation had been so disastrous that in 1850 the Privy Council, in reluctantly sanctioning the annexation of the Orange River State, had made an emphatic protest against further expansion of territory :

"We cannot pass from this part of the subject without submitting for your Majesty's consideration our opinion that very serious dangers are inseparable from the recent, and still more from any future, extension of your Majesty's possessions in Southern Africa. . . . Unless some decisive method can be taken to prevent further advances in the same direction, it will be impossible to assign any limit to the growth of these unprofitable acquisitions. . . . In humbly advising that the Orange River Sovereignty should be added to the dominions of your Majesty's Crown, we think ourselves bound therefore to qualify that recommendation by the further advice that all officers who represent, or who may hereafter represent, your Majesty in Southern Africa, should be interdicted, in terms as explicit as can be employed, and under sanctions as grave as can be devised, from making any addition whether permanent or provisional, of any territory however 
small to the existing dominions of your Majesty in the African continent, and from doing any act or using any language, conveying, or which could reasonably be construed to convey, any promise or pledge of that nature."

The wisdom of this protest was promptly justified by the Kaffir war, which made the ensuing years one of the most disastrous periods of British rule.

Earl Grey has recorded his opinion of the politica! mischief of our responsibilities in South Africa after the war:

"I cannot leave the subject of the Kaffir war, without making some further observations on the policy which has been adopted, and on that which may be followed in future. It is impossible not to perceive, that a general feeling exists in this country, that the Colony is not worth the sacrifices it imposes upon us, and that it was a grievous error to get entangled in a situation in which such sacrifices are required. With a third costly and troublesome war, hardly yet finished, less than twenty years after the commencement of the first, it certainly is not surprising that such a feeling should exist. Few persons would probably dissent from the opinion, that it would be far better for this country if the British territory in South Africa were confined to Cape Town and to Simon's Bay. But however burdensome the Nation may find the possession of its African dominions, it does not follow that it can now cast them off, consistently with its honour or its duty. It has incurred responsibilities, by the measures of former years, which cannot be so lightly thrown aside." 


\section{I2O THE BROAD STONE OF EMPIRE}

Sir William Molesworth was even more emphatic in his opposition to territorial expansion in South Africa. The boundary of our possessions gave us a frontier of 1000 miles to defend against native tribes, while every extension made it still more difficult to defend a larger frontier. His views on the general question of the limitation of our imperial responsibilities have been concisely stated in Mrs. Fawcett's Life. "A few commanding positions with good harbours should be chosen. They should be small, isolated, salient points, easily defended, and close to the beaten paths of the ocean. I hold it to be quite contrary to the true policy of Great Britain to take military possession of large islands or vast portions of continents. I consider it to be utterly absurd for an essentially naval power to attempt the military defence of extensive coasts or long lines of frontier. That attempt has been made in South Africa with disastrous and costly results." The stations he advised to be retained were "Gibraltar, at the mouth of the Mediterranean; Malta, near its centre; Bermuda, in mid-Atlantic; Halifax, commanding the coast of North America; Barbadoes, amongst the Islands of the West Indies; the peninsula extremity of South Africa, on the route to India; Mauritius, on the same road, and commanding the Persian Gulf; Singapore, at the entrance of the China Seas; and perhaps Hong Kong, amidst those seas." And estimating the cost of these stations with a total garrison of 17,000 men at $£ 850,000$, he concluded, with special reference to South Africa: "This is not much more than the sum which the colony of the Cape of Good Hope, 
with its Kaffir wars, annually costs us on an average of years. ... If we consider, as some persons do, the whole colony of the Cape to be merely a military station, then the expense of this one ill-chosen station would be equal to the expenses of our eight best-chosen stations; and the sum of money which we lavish on the Cape of Good Hope would, in my opinion, be sufficient to defray the military expense of all the stations which our naval policy requires."

The Cape had been admittedly the extreme case of military expenditure for the protection of a colony; and on this subject Sir Henry Taylor's view was expressed in the Minute already referred to in connection with our possessions in America: "I think the question should be regarded as purely philanthropic-a question whether this country thinks it her duty to save and civilise barbarous tribes, whatever be the cost, or is prepared to let loose upon them the barbarous passions of civilised men. If the former, warfare must be conducted at the Cape by British troops under British control and at the cost of the British treasury. If the latter, it is essential to this country's good name that irresponsibility should be established by separation."

\section{AUSTRALIA}

The elements of political mischief in Australia, except in regard to the general question of the control and responsibility of the English Parliament, were of a different order from the main causes of trouble in North America and South Africa. There was practically no racial or religious difficulty, and the native question offered no such formidable 


\section{THE BROAD STONE OF EMPIRE}

difficulties as were presented in South Africa by the defence of frontiers against invasion by warlike tribes. The elements of mischief were found in questions arising out of the colonisation of vast areas of territory with no adequate labour-supply. The Colonial Office ideas of colonisation consisted exclusively in giving grants of land, and supplying labour by "shovelling out of England its convicts and paupers."

The secession of the American colonies was followed by the migration into Canada of the group of colonists known as the United Empire Loyalists, but it did not divert the stream of popular migration from the United Kingdom into the United States. A few, rendered desperate by their condition after the peace of 1815 , resolved to try their fortunes in Canada, and were allowed to go wholly unprepared and destitute. It soon became known how piteous was their lot. Those who had survived the sufferings of their home life, and the miseries and hardships of the voyage, found themselves among the snows of Canada with nothing but the rags on their backs and an axe or spade in their hands. Of an organised system of emigration neither the Colonial Office nor the community had the remotest conception. On the other hand, the rapid development of the United States offered employment in every department of industrial labour. The emigrant was eagerly welcomed and found himself in circumstances that promised everything that he desired,- - not only work and wages, but, what was as the breath of his life to the Irish emigrant, a political and social environment in which he was wont to declare, "One 
man was as good as another and a d-d sight better."

What has been said about South Africa will sufficiently explain why that colony failed to attract any considerable stream of working-men from this country. For the destitute workman with his hoe or his hod, who found ready employment in the United States, South Africa had absolutely no use.

It was reserved for Australasia to instruct the Colonial Office in the arts of colonisation appropriate to the Victorian era. But the disasters of the early days of the enterprise gave no assurance of its ultimate success. They supplied, indeed, a rich contribution to the stores of those who were engaged in the policy of trying to rid the mother country of idle and useless encumbrances. The ultimate success of the art of colonisation was directly due to the work of an association formed in London in 1830 , called the Colonisation Society. The ideas of the founders of this Society grew out of the proceedings of the British Government in settling the Swan River in IVest Australia. All experience of colonisation, from the original settlement of Virginia in the reign of James the First, had taught that no scheme of settlement, however fertile the resources of the soil, can succeed without a large initial expenditure in clearing. The Colonial Office was not unmindful of this in the case of the Swan River settlement in 1829 . A grant of 500,000 acres of land round about the port or landing-place was made to one individual, Mr. Peel, who went out with a capital of $£ 50,000$, and a labour supply of working-men. What followed may be told in $\mathrm{Mr}$. 


\section{I24 THE BROAD STONE OF EMPIRE}

Gibbon Wakefield's narrative given to the Colonial Lands Committee in 1836 .

"It was quite impossible for Mr. Peel to cultivate 500,000 acres, or a hundredth part of the grant; but others were of course necessitated to go beyond his grant in order to take their land, so that the first operation in that colony was to create a great desert. The Governor took another 100,000 acres; another person took 80,000 acres; and the dispersion was so great that at last the settlers did not know where they were; that is, each settler knew where he was, but he could not tell where anyone else was, and therefore he did not know his own position. That was why some people died of hunger, for although there was an ample supply of food at the Governor's house, the settlers did not know where the Governor was, and the Governor did not know where the settlers were. Then, besides the evils resulting from dispersion, there occurred what I consider almost a greater one, the separation of the people and the want of combinable labour. On finding that land could be obtained with the greatest facility, the labourers, taken out under contracts which assured them of very high wages if they would labour a certain time for wages, laughed at their masters. Mr. Peel carried out altogether about 300 persons. In six months after his arrival he was obliged to make his own bed, and fetch water for himself and light his own fire. All his labourers had left him. The capital, therefore, which he took out-implements, seeds and stockimmediately perished; without shepherds to take care of the sheep, the sheep wandered and were 
lost, eaten by the native dogs and killed by the natives and some of the other colonists, very likely his own workmen; his seeds perished on the beach; his wooden houses were there in frame, in pieces, but could not be put together, and were therefore quite useless and rotted on the beach. This was the case with the capitalists generally. The labourers, obtaining land very readily, and running about to fix upon locations for themselves, very soon separated themselves into isolated families, like the Irish cottiers, but having, instead of a small piece of land, a large extent of land. Everyone was separated, and very soon fell into the greatest distress. Falling into the greatest distress, they returned to their masters, and insisted upon the fulfilment of the agreements upon which they had gone out: but Mr. Peel said: 'All my capital is gone, you have ruined me by deserting me, by breaking your engagements; and now you insist upon my observing the engagements when you yourselves have deprived me of the means of doing so.' 'They wanted to hang him, and he ran away to a distance, where he secreted himself for a time till they were carried off to Van Diemen's land, where they obtained food."

In the long course of ill-success that followed, the land remained worthless; the proprietors, though nominally owners of vast estates, could do nothing to develop them for want of labour, and had consequently no funds out of which to introduce and maintain a supply. In the end the colonists felt compelled to petition the Colonial Office to be converted into a penal settlement. This petition 


\section{I26 THE BROAD STONE OF EMPIRE}

was granted in 1849 , with the result that Western Australia remained long dependent upon the expenditure of British public money upon the penal establishments.

In the meantime, however, the whole system of the judicial transportation of criminals and the employment of convict labour in colonisation was meeting with formidable opposition; and the establishment of a penal settlement in Western Australia, to be supported by the British Treasury, was an effective instrument in the hands of the party who were urging the British Parliament to get rid of the useless encumbrance of colonial possessions.

In 1837 a Select Committee of the House of Commons was appointed "to inquire into the System of Transportation, its efficacy as a Punishment, its influence on the Moral State of Society in the Penal Colonies, and how far it is susceptible of improvement."

Mrs. Fawcett, in her Life of Sir William Molesworth, has quoted from the report of the Committee some evidence which may well be reproduced:

"Sir Francis Forbes, who had been Chief Justice of Australia, said, in evidence before the Committee, that the punishment of transportation had been carried out in such a way as to induce many prisoners to seek death under its most appalling aspects rather than continue in the horrors which their life brought with it. He said he had known 'many cases' in which convicts had deliberately committed crimes which subjected them to execution for the mere purpose of being sent to Sydney to be hanged. When asked, "What good do you think is 
produced by so horrible a punishment?' Sir Francis Forbes replied: 'That he thought it did not produce any good, and that if it were to be put to himself, he should not hesitate to prefer death under any form in which it could be presented to him, rather than such a state of endurance as that of the convict at Norfolk Island.' Judge Barton, who also gave evidence, was so moved by the horrors which he revealed to the Committee that he could not restrain his tears. A convict who had been brought before this judge had said: 'Let a man be what he will when he comes here, he is soon as bad as the rest; a man's heart is taken from him and there is given to him the heart of a beast.' Dr. Ullathorne, who subsequently became Roman Catholic Bishop of Birmingham, spent several years of his early life in Australia, and was Vicar-General of New South Wales. .. . It was Dr. Ullathorne's duty to attend upon the condemned men and to offer them the consolations of religion. His story is best told in his own words: 'On my arrival at Norfolk Island, I immediately proceeded, although it was late at night, to the gaol, the commandant having intimated to me that only five days could be allowed for preparation, and he furnished me with a list of the thirteen who were to die, the rest having been reprieved. I proceeded therefore to the gaol, and upon entering I witnessed a scene such as I never witnessed in my life before. The men were originally confined in three cells; they were subsequently assembled together; they were not aware that any of them were reprieved. I found, so little had they expected the assistance of a clergyman, that when 


\section{I28 THE BROAD STONE OF EMPIRE}

they saw me they at once gave up a plot for escape, which they had very ingeniously planned, and which might, I think, have succeeded so far as their getting into the bush. I said a few words to induce them to resignation, and $I$ then stated the names of those who were to die; and it is a remarkable fact that as I mentioned the names of those men who were to die, they one after another, as their names were pronounced, dropped on their knees, and thanked God that they were to be delivered from that horrible place, zohilst the others remained standing mute. It was the most horrible scene I ever witnessed. Those who were condemned to death appeared to be rejoiced. It had been a very common thing with us to find prisoners on their way to the scaffold thanking God that they were not going to Norfolk Island.',

It is no more necessary now to justify the abolition of the system of transportation than to justify the abolition of slavery. But in the condemnation of either system it is well to remember the part it has played in the development of the national resources of the world by the nations of Christendom. It is well in particular to remember that Charles Darwin, visiting Tasmania in 1836 , wrote: "On the whole as a place of punishment the object is scarcely gained: as a real system of reform it has failed as perhaps would every other plan. But as a means of making men outwardly honest, of converting vagabonds most useless in one hemisphere into active citizens of another, and thus giving birth to a new and splendid country, a grand centre of civilisation, it has succeeded to a degree perhaps 
unparalleled in history." What concerns me here is only to note that both systems were equally opposed to the elementary principle of the Victorian era that the relation of the labourer to the employer should be a relation of voluntary contract.

The issue presented to the British Parliament and the British nation, by the introduction of convict labour into Australia, was practically this: either the colonisation of Australia must be carried out by some other system than convict labour supported by the taxation of the British people, or, the costly encumbrance must be got rid of. The current opinion of the British nation was well expressed by Sir William Molesworth in the House of Commons : "I exhort and warn the House to suffer no delay in this matter if it hold dear our Australian dependencies. For many years I have taken the deepest interest in the affairs of these colonies. I am convinced they are amongst the most valuable of our Colonial possessions, a priceless jewel in the diadem of our Colonial Empire. I believe that they can easily be retained, with a little common-sense and judgment on our part; that well governed they would cost us nothing, but offer us daily improving markets for our industry, fields for the employment of our labour and capital, and happy homes for our surplus population; that the Australian Empire is in danger from the continuance of transportation to Van Diemen's Land, and I therefore move that an address be presented to Her Majesty praying for its discontinuance." The system was abolished on January Ist, I $8_{53}$.

Meanwhile, it was the work of the Colonisation 


\section{I3O THE BROAD STONE OF EMPIRE}

Society of 1830 to find an appropriate and adequate system consistent with the national and imperial policy of the Victorian era.

The new system found its ablest exponent in Parliament in the person of Mr. Charles Buller, who expounded it in a speech on systematic colonisation in April, I 843. It was a great speech, in every way worthy of the great subject of which it treated, and it is hardly too much to say that few speeches, even in Parliament, have exercised a more beneficent and permanent influence on the adaptation of the principles of the Victorian era to the uses of colonial practice. After Charles Buller's death, the system was elucidated and discussed by Gibbon Wakefield, in his Art of Colonisation, in the form of a correspondence between Mr. Mothercountry (as representative of the old Colonial Office system) and a Colonist. The general principle of the system may be stated in a few words: the organisation of a small complete society, removed with all needful appliances and equipment to a new scene where it would be bound together as at home by its mutual wants and aids, by its capital and labour, its church and schools, its gradations of ranks and employments, with equality of opportunity for all, and with sufficient powers of self-government.

The system is now embodied in our imperial policy so securely that it is difficult to realise the opposition it met with at the Colonial Office. Charles Buller declared that there should be inscribed over the doors of the Colonial Office, All hope abandon ye roho enter here. When at length the colonisation of South Australia and New Zealand 
under the new system was complete, Gibbon Wakefield declared that these colonies had been formed "In spite of the most formidable opposition from the Colonial Branch of the Government of the British Empire."

The early history of the new system of colonisation in New Zealand was a record of many difficulties arising out of the old Colonial Office methods. "It is," said Charles Buller, "a history of the war which the Colonial Office has carried on against the Colony of New Zealand. Is this an exaggerated expression? What enemy of the British name and race could, what civilised country would, have brought such ruin on a British Colony?" It is certain that the Colonial Office was not fortunate in the selection of the earlier governors. It was left to Sir George Grey, appointed in 1845 , to justify the new system. He at once repressed and protected the natives, retrenched expenditure, vindicated the honour of the British flag, and left the settlers as free as possible to manage their own affairs. The threatened but irrepressible fortunes of the colony were soon displayed as well in material progress as in moral and intellectual welfare.

Within a few years the colonisation of Australia and New Zealand by methods consistent with the principles of the new era was an accomplished fact, and the group of settlements which had been used as an effective argument in favour of getting rid of the colonies became a still more effective argument in favour of a United Empire. 


\section{I32 THE BROAD STONE OF EMPIRE}

\section{INDIA}

I have anticipated a period which was to bring about a reversal of the policy based on a belief that our colonies were politically mischievous and commercially useless. That belief was perhaps even more strongly held in respect of our possessions in Asia.

Our empire in India had its origin in a commercial enterprise that seemed of its very nature to preclude the consequences it brought about. The merchants of the East India Company, strong at first only in the weakness that disarmed jealousy, devoted themselves to their work in a spirit of conciliation which secured the confidence of their native environment. But it was an environment of conflicting powers in which the exigencies of selfpreservation compelled them to defend their persons and interests, and when they had shown that they possessed a military spirit as superior as their commercial character, they became an object of admiration to the Native Powers, who in process of time courted their alliance and aid against each other. There is no more interesting record in the annals of the Empire than the story of the events which involved the East India Company in the complication of a political State in spite of the remonstrances of their directors, who, believing the policy of their agents to be hostile to their own interests, denounced at every step the progress made towards territorial power in India. When at last the directors found it impossible to control their agents, who had become the lords of a vast territory and the dominant power 
in the field of Indian politics, they invoked the aid of the British Legislature, which eventually seconded their efforts. Pitt's Act of $\mathrm{I}_{7} 84$ declared the pursuit of schemes of conquest to be "repugnant to the wish, the honour and the policy of the British nation," and sought to give effect to the declaration by granting the British Parliament a general control over the government of India, modified by provisions expressly designed to save the interests of India from being made subservient to the interests of political parties in England, or to the private interests and fortunes of the Company's agents and servants. Twenty years later the Duke of Grafton, once the colleague of Lord Chatham who has been styled the first and greatest of Imperialists, recorded in his Autobiography (published in I 805): "I cannot bring myself fairly to rejoice when I hear the account of a splendid victory (in India) gained over some country power, which probably might have become by good management an ally, because it brings to my thoughts all the evils which, I conceive, India has brought on this country." And it is necessary to bear in mind that the greatest of our administrators, during the early years of the nineteenth century, looked upon India as a possession to be administered by a policy which would render the natives fit to take a share in the government, and at the same time enable us to maintain our dominion until they should have acquired sufficient knowledge and energy of character to govern themselves. In I 8 i 8 Sir John Malcolm wrote:

"In contemplating the probable future destiny of our extraordinary Empire in Asia, it is impossible 


\section{I34 THE BROAD STONE OF EMPIRE}

not to think but that the knowledge we are so actively introducing may in the course of time cause great changes: but how these may affect our power is a question that the wisest of us will find it difficult to answer. I must ever think that to impart knowledge is to impart strength to a community, and that, as that becomes enlightened, the love of independence, combined with a natural pride in self-government, which God appears to have infused into the spirit of men and of nations, will be too strong for all the lessons of duty, of meekness, and of gratitude to their intellectual benefactors that we can teach our Indian subjects; but I am not deterred by the possibility (nor should I be by the probability) of such consequences from being the advocate of their instruction in all the arts of civil life."

And in I822 Sir Thomas Munro, anticipating a time when, by proper measures, we should have so far improved the character of our Indian subjects as to enable them to govern and protect themselves, declared that when that time should arrive, it would probably be best for both countries that the British control over India should be gradually withdrawn.

For some time prior to the Mutiny the affairs of India had been watched with jealous eyes. Cobden and others, - and they were many-looked on India as a "military and despotic government; as an acquisition of impolitic violence and fraud; as the seat of unsound finance" ; and could see no advantage in the vast possession. Even so cool and impartial an observer as Charles Greville wrote, "I have long expected that the day would come when we should find reason for regretting our expansion 
policy (in India)." When the Mutiny broke out, there were many who despaired of the possibility of our ever governing India with advantage either to the natives or ourselves. The Mutiny was followed by operations in China, and again Charles Greville gave expression to the views of society when he wrote: "I always tremble for the consequences of our excesses (in China) that we should be induced or compelled into further extensions of our empire in the Far East."

\section{TROPICAL COLONIES}

It remains for me to deal with the reasons which prompted a policy of withdrawal from the group of our tropical possessions now associated under the designation of Crown colonies.

In no part of the world has the swing of the pendulum between a policy that held the possession of colonies to be a political and commercial necessity and a policy that held them to be politically mischievous and commercially useless been more active than in the tropics. The history of western civilisation from the discovery of America to the treaty of Paris in $18 \mathrm{I} z$ is the history of a struggle for the control of the tropics by conquest, trade, or occupation. The treasures of the tropics were an apple of discord on which Portugal, Spain, Holland, France, and Great Britain in rapid succession left the marks of their teeth. It was in this way that the West Indies became admittedly the nerve centre of the universe. And yet Great Britain had no sooner established her control over the Caribbean Sea than the swing of the pendulum reversed the 
policy that had acquired it. The reason is to be found in the way that, in the tropics, political exigencies are entangled with commercial uses. For generations the laws regulating the commerce of the Plantations, as the earlier tropical colonies were called, had applied only to sugar, the staple of production, and Lord Beaconsfield summed up the difficulties that arose out of this entanglement of interests in words already quoted but which will, I trust, bear repetition:-_"Sugar has been embarrassing, if not fatal, to many Governments. Strange that a manufacture which charms infancy and soothes old age should frequently occasion political disaster. ... Singular article of produce! What is the reason of this influence? Is it that all considerations mingle in it; not merely commercial, but imperial, philanthropic, religious; confounding and crossing each other, and confusing the legislature and the nation, lost in a maze of intersecting and contending emotions?"

All these considerations had their root in the conflict of principles between the policy of the Victorian era and the policy that had preceded it. The policy of centuries had been a policy of force in every political relation both foreign and domestic. Territory was acquired and held by force of arms, order was maintained by the terrors of the criminal law, the soil was cultivated by slaves, and the profits of cultivation depended on the protection of trade-routes by fleets and garrisons. The policy of the Victorian era was a policy of government by consent of the governed, labour by voluntary contract, and free trade. The abolition of slavery in accord- 
ance with this policy threatened the foundation of the whole structure. The substitution of a system of labour by voluntary contract was a work of great difficulty, while in the meantime, every branch of private industry and every department of public life were threatened, because every branch of private industry was subsidiary to and dependent on the fortunes of the planters, and there was no source from which the emoluments of the learned professions, or the expenditure required for the maintenance of a civilised government, could be derived except the annual profits of the plantations. The cost of defence had always been borne by the government; but on the other hand it is important to remember that, apart from the revenue derived from the customsduties, the Crown had a right to the surplus revenue of all the Crown colonies. Indeed, an unrepealed Act, the Crown Revenues (Colonies) Act of $185^{2}$, seems to require that such surplus revenues should still be carried to the Consolidated Fund.

The abolition of slavery had, at every stage, been resisted by the colonial legislatures with an intensity of exasperation which for years left its mark in a disposition to resent the interference or even the advice of the Colonial Office. But the consequences of abolition were for some years mitigated by the exclusion from consumption in England of all slavegrown sugar. In i 845 , however, the policy of Free Trade secured the repeal of this exemption. It is not without interest to recall the public opinion of the day as expressed by Lord Macaulay in the House of Commons, during a debate on the Sugar Duties, on February 26th, 1845 . He said:- "I at 
the same time ( 1833 ) heartily joined in laying a heavy burden on the country for the purpose of compensating the planters. I acted thus, because, being a British legislator, I thought myself bound, at any cost to myself and my constituents, to remove a foul stain from the British laws, and to redress the wrongs endured by persons who, as British subjects, were placed under my guardianship. But my special obligations in respect of negro slavery ceased when slavery itself ceased in that part of the world for the welfare of which I, as a member of the House, was accountable. As for the blacks of the United States, I feel for them, God knows. But I am not their keeper."

The situation thus created did indeed furnish powerful arguments to the party who desired to get rid of the West Indies as both mischievous and useless. It brought the local Governments into constant conflict with the British Parliament on the one hand, while on the other the relation of the governing class to the emancipated population was one of constant danger. At the same time, the policy was proportionately increasing the obligations of the British Parliament, admittedly in the last resort responsible for external defence and the maintenance of internal order through the agency of a civilised government, the cost of which, moreover, was a constant source of exasperation. The exigencies of economy and of efficient administration were hard to reconcile. In Lord Beaconsfield's novel of Popanilla, a speck upon the sea, originally mistaken for a porpoise, proves to be a rock, and is immediately provided with the equipment of a civilised govern- 
ment. "Upon what system," asks Popanilla, "does your Government surround a small rock in the middle of the sea with fortifications, and cram it full of clerks, soldiers, lawyers and priests?" "Well, your Excellency, I believe we call it the Colonial System."

As it is a principal object of my work to illustrate the system by which the conflicting interests of the British Parliament and the Crown colonies have been reconciled and the political and commercial necessity of our tropical possessions established, I need not now discuss it. I pass on to consider the operation in Africa of the policy which sought to relieve us from the embarrassments of our tropical colonies in America.

Our colonies in West Africa had their origin in the needs of the West Indies, and here again we observe the swing of the pendulum. Established with the main object of supplying the slave trade, they came to be maintained with the main object of suppressing it. The Gold Coast and Gambia settlements were formed by companies who received charters to hold and govern forts, without acquisition of territory, for the purpose of promoting the trade in slaves and in gold. From a very early time the trade was carried on largely by an interchange of arms and liquor. The abolition of the slave trade ruined the companies, and in $182 \mathrm{I}$, the settlements were placed under a central British administration in Sierra Leone. Twenty years later, in 1842 , the administrative system was revised; Gambia and the Gold Coast became separate governments; some abandoned forts were re-occupied 


\section{I4O THE BROAD STONE OF EMPIRE}

and others built, not for territorial extension, but to control the native chiefs and the slave trade they were then actively carrying on with America. In I86I a consulate at Lagos was added to the settlements, and in 1865 a Select Committee of the House of Commons, of which Lord Norton was chairman, was appointed to consider the state of the British establishments on the Western Coast of Africa. Their position was found to be briefly this. Imperial funds provided a grant of $£ 14,000$ a year for the civil establishment, in addition to charges for liberated slaves, and missions; a sum of $£ \mathrm{I} 30,000$ a year for the garrison, in addition to barracks, hospitals, and stores; and a sum of $£ \mathrm{r} 57,869$ a year for vessels and gunboats employed in the suppression of the slave trade. The total expenditure from imperial funds was estimated at about $£ 320,000$, or nearly one half per cent. of the total revenue of the United Kingdom. The report of the Committee recommended an immediate reduction of expenditure, and advised, "that all further extension or assumption of government, or new treaties offering any protection to native tribes would be inexpedient, and that the object of our policy should be to encourage in the natives the exercise of those qualities which may render it possible for us more and more to transfer to them the administration of all governments, with a view to an ultimate withdrawal from all except, probably, Sierra Leone."

That this report was in accordance with the fixed determination of both political parties to resist extension of territory in tropical countries 
is clearly proved by a speech of Mr. Cobden in I 853 on Sir Charles Wood's India Bill:

"With an enlightened public opinion brought to bear more directly on the affairs of India, there will be a better chance of avoiding that source of all fiscal embarrassment, constant wars, and constant annexation of territory. In other parts of the world, no Minister of the Crown would take credit for offering to annex territory anywhere. On the West Coast of Africa, it might not be less profitable to extend our territory than in Burmah; yet a resolution of a Committee of this House, many years ago, forbad the extension of our territories in tropical countries. When an adventurous gentleman, Sir James Brooke, went out and took possession of some territory on the coast of Borneo, the enlightened government of Sir Robert Peel and his colleagues resolutely resisted all attempts to induce them to occupy any territory there. Recently, when it was announced in this House that orders had been given to the admiral on that station that on no account should any fresh territory be acquired, the announcement was received with loud cheering. We had arrived at a point when public opinion in this House and the country would prevent any such thing; and I believe the leading statesmen on both sides would resolutely set themselves against any extension of our territory in tropical countries"

A few years later; in 1869 , Lord Norton, who had in the meantime held the office of Under Secretary for the Colonies, expressed his own views, and presumably the views of the Colonial 


\section{I42 THE BROAD STONE OF EMPIRE}

Office, on the general question of the duty of the Imperial Government towards the Crown colonies.

"The advantage to England of such Dependencies, which are now beginning to pay more of their own expenses, consists in their assistance to commerce, encouragement of enterprise, or in furthering and extending Imperial interests throughout the world. Such possessions the Sovereign of Great Britain holds for special purposes, and may, if these objects cease to exist, abandon, cede, or exchange at any time, only fulfilling engagements made and securing interests created. They are not extensions of Empire, like national settlements, which, if we only abstain from crushing them by protection and allow them to act as partners with ourselves, will retain a connection of nationality with us for ever; they are merely occupations for use, and may be alienated without any national severance."

In respect of the West African Settlements, in particular, Lord Norton dismissed as impracticable, for climatic and others reasons, a scheme advocated by Wilberforce for turning them to account for the development of civilisation and commerce, and again urged the recommendations of the Committee for their gradual abandonment.

Having now taken a survey of the elements of political mischief in our over-sea dominions that prompted the policy of "standing by to let go the painter," we may consider the question whether the political risks were counterbalanced by commercial advantages. The chief element of political 
mischief lay in the claim of the colonies to enjoy any possible advantage from their imperial connection while unwilling to share responsibilities that might arise. They claimed complete freedom of action in internal and external affairs, while the imperial government was to hold them immune from the consequences. The skirts of empire were to be trailed about the world for any foot to tread on. Mr. Gladstone, in his evidence before a Select Committee on Colonial Military Expenditure which reported to Parliament in I 859, showed how absolutely this claim was at variance with their original relation to the mother country. He observed that, in the old colonial system, the primary responsibility for selfdefence, which, he said, was all he claimed, was borne by all the colonies under circumstances when they were almost certain to be drawn into entirely English quarrels, and to be made directly the subject of contests among European Powers. Mr. Lowe, who could speak with the authority of a former member of the Legislative Council of New South Wales, argued in the same sense, declaring that the question discussed was the reverse of that of the last century, and that to tax English labourers to relieve New South Wales from paying for the primary duty of its own defence was a crying injustice. The formidable consequences of the claim made by the colonies for complete immunity of responsibility prompted $\mathrm{Mr}$. Lowe some years later, in 1867 , to declare in the House of Commons: "In the time of the American Revolution the Colonies separated from England because she insisted on taxing them; what I now apprehend as likely to 


\section{I44 THE BROAD STONE OF EMPIRE}

happen is that England will separate from her Colonies because they insist on taxing her." But to revert to the Committee of $1859, \mathrm{Mr}$. Gladstone, in reply to a question whether the old colonies were not more independent than at that time, said: "On the contrary, it would undoubtedly not have been permitted to those Colonies to exercise any power to legislate adversely to the Mother Country, whereas we have recent experience in Canada that even that power may be exercised by our present Colonies with a view of raising up a protected interest against the commerce of the Mother Country." Evidently there was ground for the belief that the abandonment of the old colonial mercantile system for a system of Free Trade, without reciprocity, was rendering the colonies commercially useless. To appreciate the full significance of the change of policy, it is necessary to recall the principles of the old colonial system. They have been most concisely stated in Bryan Edward's History of the British West Indies :

"The leading principle of colonisation in all the maritime States of Europe (Great Britain among the rest) was commercial monopoly. The word monopoly in this case admitted a very extensive interpretation. It comprehended the monopoly of supply, the monopoly of colonial produce, and the monopoly of manufacture. By the first, the colonists were prohibited from resorting to foreign markets for the supply of their wants; by the second, they were compelled to bring their chief staple commodities to the mother country alone; and by the third, to bring them to her in a raw or unmanufactured state, that her own manufacturers might secure to themselves 
all the advantages arising from their further improvement. This latter principle was carried so far in the Colonial system of Great Britain, as to induce the late Lord Chatham to declare in Parliament that the British colonists in America had no right to manufacture even a nail or a horseshoe."

A principal argument in favour of Cobden's Free Trade policy was the assurance that it would be reciprocated. In the absence of reciprocity on the part of our colonies there was some reason for the argument that they were commercially useless, and that the economic salvation of the United Kingdom was to be found in a cosmopolitan system of commerce without distinction of colonial or foreign origin, for it was still an article of faith that the policy of universal Free Trade would sooner or later break down the walls of Protection. 


\title{
CHAPTER V
}

\section{OUR IMPERIAL POLICY}

\author{
I868 AND AFTER
}

IT has been justly remarked that the more closely one studies history, the more fully one recognises that all divisions into epochs or stages, marked by events such as the accession of sovereigns or the foundations of institutions, have in them something arbitrary. If then I adopt the formation of the Royal Colonial Institute as a landmark in colonial history, it is merely because it brought into focus some leading characteristics of a period of transition between a policy which believed our colonies to be both mischievous and useless and a policy which held them to be both politically and commercially necessary.

The Royal Colonial Institute had its origin in a revolt of the national conscience against the policy of laisser faire; in a conviction that the Empire means the deliberate and reasoned union of a selfconscious community rather than a collection of indeterminate atoms, and that the administration of an empire must be guided by the principle,Imperium servatur non ratione imperii sed rationis 
imperio. The founders of the Institute included representatives of the self-governing colonies, India, and the Crown colonies, men who had held high office in colonial administration, and members of the Imperial legislature who had taken part in the discussion of the leading questions of colonial politics.

While the motives that concentrated the policy of the founders of the Colonial Institute were many, the dominant influence was the direct outcome of the consequences of the civil war in the United States. To the hold of our colonial policy on public opinion between i 860-70 must be attributed that aberration of the national intellect which found expression in sympathy with the secession of the Southern States from the Federal Union. The successful assertion of the Federal supremacy and the consolidation of the great Republic gave it a rude shock. It exposed the fallacy underlying the conduct of the Government towards the United States during the war, the belief that the disintegration of the Union, accepted by Mr. Gladstone as an accomplished fact, would result in substituting for a continental empire with island outposts a group of independent nations in close analogy to the system contemplated by our own colonial policy. The actual result, so contrary to anticipation, at once led thoughtful and unprejudiced minds to reconsider the principles of that policy in the light of the new revelation, and to test by analogy the soundness of the doctrine that England would be as great without her colonies as with them.

In order to understand the full significance of the 


\section{I48 THE BROAD STONE OF EMPIRE}

result of the civil war in its bearing on our colonial policy, it is important to understand clearly its bearing on the policy of the United States. In 190I a concise but exhaustive account of the expansionist policy of the United States immediately following the war was published in The Political Science Quarterly, and to Mr. T. C. Smith, the author of that account, I am mainly indebted for what follows.

The policy of the Government of the United States after the civil war had for its ideal the federation of the whole of North America under a central administration, with protectorates over Central and South America. This policy, under the phrase "manifest destiny," had been familiar long before the civil war. It had been the motive of the struggle for Canada when the thirteen colonies seceded ; it lay at the root of the purchase of Louisiana in $1 \mathrm{SO}_{3}$, and of Florida in 1819 , as well as the annexation of Texas in $\mathrm{I} \mathrm{S}_{45}$; it entangled Presidents Pierce and Johnson in schemes to annex Cuba. It had found expression in a long series of filibustering raids into Canada, Central America, and Cuba. In popular jargon, the American eagle had long squinted with one eye on Canada and the other on Cuba. The supreme question at issue during the civil war was whether the United States, as constituted at the commencement of the war, were to be disintegrated, and the policy of manifest destiny thus destroyed at its root. The resumption of the policy after the question had been decided was influenced by additional motives arising out of the war. It was believed that the enthusiasm of this imperial idea would be a powerful force in the 
reconstitution of a patriotic movement, and that this movement would find additional strength in a sense of exasperation against the hostility to the Union shown during the war by every European nation except Russia, and a sense of gratitude to Russia for her profession of friendship.

The work of domestic reconstruction so entirely occupied President Johnson during the period immediately following the close of the war that the auxiliary scheme of territorial expansion was practically left to the Secretary of State, Mr. W. H. Seward, an eager expansionist.

So soon as the pressure of war began to diminish, Mr. Seward opened negotiations for a naval station in the West Indies to secure what the events of the war had shown to be a supreme necessity to his policy, - a base for the control of the Caribbean Sea. After opening negotiations with the Danish Minister for the purchase of the islands of St. Thomas, St. John, and Ste. Croix, Seward proceeded on a visit to the Danish islands, which he extended to San Domingo, Haiti, and Cuba. The result of this expedition was a second negotiation with the President of San Domingo for the purchase of Samana Bay as a naval station. These negotiations were delayed, in the case of the Danish islands by the unwillingness of the Danish Ministry to sell them, in the case of San Domingo by an outbreak of revolution in the island. But early in 1867 Russian initiative offered an unexpected opportunity for annexation. Mr. Seward had referred to the Russian Minister a petition of the Washington territorial legislature for better fishing privileges on 
the shores of Alaska. The reply was a proposal to sell to the United States the Russian possessions in North America. After a very brief negotiation, terms of cession were agreed upon; a treaty was signed during the night of March 3oth, 1867, submitted to the Senate on April ist and ratified on April 9th. On October I 8 th, although it still remained for the purchase money to be appropriated by the House of Representatives, formal possession was taken. Up to this moment the policy of expansion, though interrupted in the West Indies, seemed assured of early success by the contributory action of the foreign governments concerned. The Russian and Danish governments were prompted mainly by the desire to exchange outlying possessions of little value for ready money. In the case of Russia there was added the political motive of a desire to have the friendly United States as a neighbour in preference to England. As regards San Domingo, there was at the time an almost universal belief that the President, a military adventurer, and his friends were actuated by personal and selfish views, and that the official negotiations were supported by intrigues between the San Domingo government and New York, arising out of concessions, grants, and other speculative interests.

Thus everything seemed to favour Mr. Seward's policy at the moment when it became necessary to obtain the sanction of the House of Representatives. Then it became evident that, while the policy of manifest destiny continued to do service as platform oratory, public sentiment was not prepared to accept it. On November 25th, 1867, within six 
weeks of the act of taking formal possession of Alaska, the following resolution was adopted in the House of Representatives without a division: "That in the present financial condition of the country any further purchases of territory are inexpedient, and this House will hold itself under no obligations to vote money to pay for any such purpose unless there is greater necessity for the same than now exists." The mover of the resolution explained that it was not intended to apply to Alaska but more particularly to St. Thomas. "I intend," he said, " to serve notice upon the kingdom of Denmark that the House will not pay for that purchase." On June 3oth, I 868, the appropriation for the Alaska purchase money was introduced, and gave rise to a debate on the general question of expansion. The fact of actual possession secured the passing of the appropriation for Alaska, but not without vigorous censure of the whole policy and of this particular instance. Meanwhile, in January, I 868, a plebiscite was held in the Danish islands and annexation unanimously approved; but when the treaty for annexation came before the Committee of the Senate for Foreign Affairs it was for a time postponed, and in I 870 definitely ended by an adverse report. The San Domingo scheme, after passing through various phases which need not be discussed, was finally abandoned in $187 \mathrm{I}$.

In considering the expansion movement of the period $1865-75$ as a whole, it is easy to see that the motives that controlled it were identical with the motives that controlled the policy of Great Britain during the period 18 I $7-68$. The policy that 


\section{I52 THE BROAD STONE OF EMPIRE}

prevailed in Congress was based on the internal conditions of the country at the close of the civil war.

"Burdened under a mountainous debt, obliged to grapple with the difficulties of a depreciated currency and the reduction of the war taxes, the country was in no mood to incur large new expenditures. The harassing problem of reconstruction, involving the military control of eleven states, absorbed attention and made the prospect of additional dependent territory unattractive. Finally, the economic interests of the country, although expanding with prodigious rapidity, were turned irresistibly toward internal development, - to railways and manufactures and away from shipping and foreign trade." 1

"The first duty of the American public is to its own people," said The Nation.

On the other hand, throughout the whole period the sentiment of expansion as an inevitable destiny found expression in Presidential Messages, in the language of Congress, of naval and military authorities, and in the Press. President Johnson declared that "Comprehensive national policy would seem to sanction the acquisition and incorporation into one Federal Union of the several adjacent continental and insular communities." President Grant, who succeeded Seward as leader of the annexation movement, declared of San Domingo that, "It commands the entrance to the Caribbean Sea and the isthmus transits of commerce," and repeatedly stated that unless the United States annexed San Domingo some European nation would do so at once: "If 
refused by us, by what grace can we prevent a foreign power attempting to secure the prize?" Senator Sumner advocated the Alaska treaty, and urged that Canada ought to be ceded by Great Britain in adjustment of the Alabama affair, as steps towards an avowed claim that all North America must become part of the Union. Representatives of every State, from the Pacific to the Atlantic, gave expression to the sentiment in the Senate and in the House of Representatives. "We rise from rebellion, conscious of our power, full of hope and confidence," said one; "such a nation cannot shrink from her destiny, she welcomes it." "Nothing less than a continent," cried another, "can suffice as the basis and foundation for that nation in whose destiny is involved the destiny of mankind." "Give us Alaska," said a representative of California, "and right soon we will make California so great that you will all boast when you go abroad that you live under the same Federal Jurisdiction as we do." "The possession of Alaska," it was urged at the same time, "is the key to the Ocean." Nor were declarations in favour of tropical expansion less emphatic. "The West Indies," said General Butler, "belong to us by position and the laws of Nature." "St. Thomas," said Admiral Porter, "is a central point from which all or any of the West Indian Islands can be assailed, while it is impervious to attack. It is the keystone to the arch of the West Indies." "San Domingo," said a representative from Ohio, "is the key to the Gulf of Mexico, a prize to any power; to us it is only less than a necessity." "I regard it as destiny not to be 


\section{I54 THE BROAD STONE OF EMPIRE}

diverted by any power," declared a Senator, "that we shall acquire San Domingo and Cuba and Puerto Rico."

Nor was the sentiment of manifest destiny less popular in the Press. "The principle of Chinese exclusiveness and non-expansion," said The Nerv York Herald, "finds few advocates. The progress of a great, active, and ambitious nation cannot be restrained." The New York Tribune, which had vigorously opposed Seward's policy in 1867 , declared, in February, I 869, that the leading men of San Domingo "deem it best, so we are assured, to join their fortunes with ours and work out the problem of their fortune under our flag and under our institutions." "Alaska," urged The New York Times, "gives us the key of the Pacific."

We may now consider briefly the general result of the events indicated in their bearing, first, on the immediate and future policy of the United States, and, secondly, on our own colonial policy. They gave incontrovertible proof that the motive power of expansion had already dominated the Federal Government and was stirring the latent forces of popular opinion. They proved, not less clearly, that the result of the civil war had placed the United States in a position to carry out a policy of territorial extension by any of the only three possible methods,--the only methods by which private or public possession can be obtained, gift, purchase, or plunder. By gift, I mean, of course, the free assent of the community. Acquisition by this method the whole colonial policy of England had justified them in expecting, alike in North 
America and the West Indies. By purchase they had acquired Alaska, and had shown their readiness to acquire the Danish islands. The whole argument in acquiring naval bases on the Pacific or in the Caribbean Sea rested on the possibility or probability of expansion by plunder or conquest.

It is hardly necessary to expatiate on the bearing of all this on the colonial policy of England. It was a main factor in concentrating English and colonial opinion on the policy which found expression in the Colonial Institute.

The Royal Colonial Institute, formed by a Society called the Colonial Society in I 868, was incorporated by Royal Charter in 1882 . At a preliminary meeting called by the promoters on June 26 th, I 868 , the aim of the Society was declared to be to arouse the country from the indifference with which it treated colonial subjects, and, by spreading a knowledge of the importance of the Colonial Empire to the interests of the United Kingdom, to "dispel the erroneous notion that pervaded some minds that England would be as great without her Colonies as with them." In more homely, but not less intelligible, phrase another speaker declared that, "There had been springing up of late years a number of half-political charlatans, half-ignoramuses who were contending that the Colonies were of no use to the Mother Country." He hoped that by conveying a more accurate idea of our colonies to people of this country, and by affording opportunities for the interchange of knowledge amongst the colonies themselves, the association might serve as a means for bringing together into one focus the various 


\section{I56 THE BROAD STONE OF EMPIRE}

sections and interests, at the time confused and chaotic, that go in their aggregate by the name of the British Empire, and tend to strengthen the links by which the colonies are united to the mother country.

The meeting adopted the following resolutions :

"That it is expedient to form a Society to be called the Colonial Society ;

"That the objects of the Society be as follows: To occupy as regards the colonies the position filled by the Royal Society with regard to science, or the Royal Geographical Society with regard to geography ;

"That a lecture-hall, a library and reading-room, and a museum of science, industry and commerce, be opened as soon as the funds of the Society will allow, where the natural products and resources of the Colonies will be exhibited; to afford opportunities for the reading of papers, and the holding of discussions upon Colonial subjects ; and to undertake these investigations in connection with the Colonies which are carried out in a more general field by the Royal Society, the Society of Arts, the Royal Geographical Society, and of similar bodies in Great Britain ;

"'That the Colonial Society be non-political, and that any organisation for political purposes be forbidden by the fundamental rules of the Society."

On March loth the inaugural dinner of the Society was held, and the Chairman, Viscount Bury, proposed the toast of the Queen to an assemblage, as he proudly declared, absolutely unprecedented. "There is," said Mr. Gladstone, then Prime Minister, 
"there is no degree of latitude and no degree of longitude, upon the whole surface of the globe, I may almost say, which has not offered its contribution to this meeting." Naturally, the orators were many, and so many were chosen that the Chairman was constrained to issue to a distinguished guest a mandate to this effect: "If you have got a speech, cut it very short, for I have on my list a lot of bigwigs, whom they are very much more desirous of hearing than you." I may claim historic importance for the speeches of three of the bigwigs, the American Ambassador (Mr. Reverdy Johnson), the Prime Minister, and Lord Granville, who had recently entered on the office of Secretary of State for the Colonies. After the loyal toasts the Chairman, proposing the "Prosperity of the United States," said with felicity of phrase, "The descendants of Great Britain's younger sons greet the representative of the eldest born." In considering the terms of Mr. Reverdy Johnson's reply, it must be remembered that the United States were still smarting under a sense of the sympathy, open or avowed, with the secession movement shown by the British Government and the great majority of the ruling classes, and the illwill of England and France against the North. It was natural, therefore, that he should dwell on the importance of a firm, sincere, and constant friendship between Great Britain and the United States. At the same time he deemed it consistent with the circumstances of the occasion to forecast an American policy of expansion, by conquest or treaty, in terms that supplied perhaps a more convincing justification for the existence of the 
Colonial Institute than the abundant rhetoric of the evening. I quote from the Institute's Journal of Proceedings.

"The people of the United States can never be indifferent to the opinion of such gentlemen as those in the presence of whom I now stand, representing, as I am told, nearly all the Colonies of your Kingdom, and having amongst them those who have conducted your Imperial Government with an ability, which it is believed, as far as oratory is concerned, was never excelled. The people of the United States will hail with delight the fact that, in the person of their representative, you have done honour to them ; and I beg you to be assured that, however it may for a time appear that, owing to the natural effervescence of feeling incident to a Republic, and owing also to causes to which I only dare to allude, there may be considerable evidences of unkindness to the mother country, you may be satisfied that in the hearts of the sober and reflecting people of my country, there exists a fixed and determined love and adoration for England. ... We, my Lord, have now no Colonies. I say 'now.' In the beginning of our Government doubts were entertained, - not doubts, perhaps-I should rather say settled opinions were entertained, that under the Constitution of the United States there was no authority whatever to enlarge the territorial dominions which then belonged to the United States. But those doubts have long since been removed, and now the opinion of all is, that the Government of the United States has the power, either by conquest or treaty, to obtain territory anywhere, whether continuous or 
not. And, my Lords, it is possible with your consent, but not without (God forbid that any attempt of the sort should be made without the consent of both parties!), that some of the Colonies which now flourish under the dominion of Her Majesty, and have so much reason to be proud of that dominion, may in process of time find themselves under the stars and stripes of the flag of the United States, where, if they shall come, they will soon find that there also they will have a country of which they and all Englishmen may have occasion to be proud. But that day, I trust, is far distant. God forbid that any part of the dominions of Her Majesty should be curtailed!"

Mr. Gladstone, in proposing the toast of the Colonial Society, refrained from any reference to the Ambassador's declaration of America's policy of expansion; he limited himself to expressions of goodwill towards the United States and some observations on the great change that had taken place in the policy of the Colonial Office since he first held office in that Department.

"It is so long, my Lord, since I was permitted to plead any special interest in Colonial affairs, that probably the circumstance of my ever having had a title to plead such an interest has passed from the memory of those who ever knew it, and to most of those who sit at this Board it will be totally unknown. It is thirty-four years since I was first a member of the Staff of the Colonial Department; it is twenty-three years since I last held office in that Department. If I advert to those dates, it is not for the sake of gratifying an anti- 
quarian curiosity, nor for the sake of pointing out what I am afraid is a truism as well as a truth, namely, that those who once have been young are apt in the course of time to grow old. It is for a very different purpose and for a worthier purpose. Looking over these years, no one can fail to be struck with the great change (and that change I will venture to say has been all improvement), which has in the interval passed over the spirit of our Colonial policy. In the days when I was accustomed to wear out with my footsteps the stairs of the Colonial Office, that Office was haunted by a disembodied spirit, which spirit received a painful distinction under the title of 'Mr. Mothercountry'; and, while that description conveys no inaccurate idea of the narrow traditions which still hung about the conceptions of English statesmen, more or less, although they were in process of being discharged, at that period, on the other side of the water also, in every British Colony there was a party, which I rejoice to think has since been totally extinguished, under the name of the 'British Party.' I believe that I speak within the hearing of those who remember the circumstances and struggles of those times, and many of us in this country were taught to believe, or at least, efforts were made to teach us, that upon this 'British Party,' which invariably represented an insignificant minority, depended the whole hope of maintaining the connection between England and its Colonies, and that if anything were done to offend that 'British Party,' or to recognise the vast majority of the Colonial community as having a claim upon our sympathies 
and our actions, such a policy was certain to be fatal to the Colonial Empire. My Lords and Gentlemen, this was a state of things so strange, that to recall it now seems like bringing back from the grave the spirits of the dead, so wholly is that state of things without a representative in the condition of affairs which now exists."

It was impossible for Lord Granville as Colonial Minister to let the Ambassador's phrases pass without direct notice.

"I am indeed rather afraid [he said] that the Minister of the Great Republic, who has spoken with such singular eloquence to-night, will feel it a little want of sense on my part, or possibly novelty in my office, which makes me unprepared at this moment to open negotiations with him for ceding the British Colonies to the Great Republic. But I can assure him that I have sufficient sense to appreciate at their just value those powerful expressions of his, going to prove that it would be absolute insanity for that great country and ourselves to be ever on any other than the most friendly terms."

The recent transfer of the whole of British North America, excepting British Columbia, to the Dominion of Canada supplied Lord Granville with a subject eminently appropriate to the occasion. Sir George Cartier had spoken with enthusiasm of the policy which had allowed the people of Canada to set their own brains to work and present their own scheme of representation for adoption by the Imperial Parliament; and Lord Granville added a pleasant touch to the history of the negotiations connected with the transfer in which he was himself concerned. 
"I own [he said] that for a very long time I was perfectly hopeless of any amicable arrangement being come to on this important subject. My right hon. friend, Sir Stafford Northcote, though a strong political opponent, and Sir Curtis Lampson, both enjoying the confidence of the Hudson's Bay Company, have treated me with the utmost kindness and courtesy, and I must add, patience, but their opinion appeared to be as widely divergent as it is possible to imagine. My right hon. friend, Sir Stafford Northcote, availing himself of our long intimacy, expressed himself to me in rather strong language. He said that I was 'a terrible screw.' It is perfectly clear that the representatives of the Dominion considered me as a quasi representative of the Hudson's Bay Company itself. My Lords and Gentlemen, I had but one weapon in my defence, but that weapon is, I admit, a powerful one, both in public and private transactions; it may be termed the power of bore. I bombarded all these four gentlemen with despatches, with private letters and with confidential notes. I plied them with interminable talk, and at last, when I judged them to be exhausted and prostrate under the effects of sheer fatigue, after a due consideration of what I believed to be imperial interests, I fired into them a new and final proposal equally unpalatable to all; but which, I think, may possibly be accepted by them as something like a reasonable compromise."

Lord Granville concluded his speech with the announcement, happily appropriate to the occasion, of the reorganisation of the Order of St. Michael and St. George, in the following terms. 
"I do not know whether you are aware that my noble predecessor obtained Her Majesty's sanction to reorganise the Order of St. Michael and St. George, and to extend it to all the Colonies, and entirely to remodel its Statutes. This work was finished so shortly before the change of Government that the noble Duke had only time to name to the second and third classes some gentlemen whom his judgment and experience enabled him to select; and he told me that he had made an application to obtain from the Queen permission to give the Grand Cross to Lord Monck, as a just tribute to his able administration of the Government of Canada. There is obviously one objection to an exclusively Colonial Order. I believe that the noble Duke was stimulated by the example of the Star of India, and that it was also confirmed by the difficulty of obtaining the Order of the Bath for persons connected with the Colonies, who had justly earned the honour. But I think that, from the affection which is entertained towards the mother country by the colonists, they would feel it to be an annoyance if they were dissevered from equally eminent men connected with the Imperial Government at home. For this reason I have very great satisfaction in stating that, not only $\mathrm{His}$ Royal Highness, the Duke of Cambridge, has consented to be the Grand Master of the renovated Order, but that Lord Derby, Lord Grey, and Lord Russell have accepted the offer of the Grand Cross which I was empowered by Her Majesty to make to them. It may readily be imagined that these three statesmen so well known in this country, two 
of whom have been the dispensers of titles and decorations to many others, and the career of one of whom has been so singularly independent, should not now wish for any additional honour which their Sovereign could confer upon them; but I believe they felt that it was for the public interest that, in this almost new Order, statesmen prominently connected with Colonial affairs should be included in the first batch. Now, it happens that it is impossible to find three men who have more fulfilled that condition. Lord Derby's name was associated with that Act for the abolition of slavery which is one of the most glorious and disinterested measures which adorn the history of this country; Lord Russell gave self-government to our North American Colonies; while Lord Grey did the same in a great measure to our Australian Colonies, and has left his strong mark upon all the principal questions of Colonial policy. It will be my humble duty to try to maintain the honourable character which has thus been placed upon this Order, and to confine my recommendations, as long as I have the honour of being connected with the Colonial Office, to those who have done real and great service to that Empire 'upon which,' if I may be allowed to repeat that well-worn but grand old Castilian phrase, "the sun never sets." "

Lord Granville's predecessor was the Duke of Buckingham, but the reorganisation of the Order suggests the spirit of the Prime Minister, Lord Beaconsfield, whose imagination had been recently touched by the Abyssinian expedition which in this annus mirabilis had "planted the banner of St. 
George on the mountains of Rasselas." It appears from a passage in Sir Henry Taylor's Autobiography that Lord Granville was not in favour of the extension of the Order, but accepted it as an accomplished fact.

It had been from the first determined that India should not be excluded from the objects of the Institute, and Sir Bartle Frere, responding for India in the absence of the Duke of Argyle, reminded the gathering that if in the colonies Great Britain had furnished at least the greater portion of the materials of which they are composed, in India Great Britain furnishes the cement which binds together its component parts, and that without that cement there could be no peace, there could be no prosperity in India.

A phrase of the Duke of Manchester in the course of the evening is worth recording. He expressed a hope that the social gathering might lead to a Council in which the colonies and Great Britain might be represented in due proportions, concluding his speech in these words: "I only hope that at some future day, all the representative and legislative bodies of the British race, represented as they are at these tables, and, which, we may say, encircle the globe, may find some central body in the Constitution of the Empire, with effective legislative power and an influence over the destinies and the laws of the colonies."

This suggestion was taken up by the Colonial Society who proposed a Conference in London of representatives duly authorised by their respective governments to consider it. It was vigorously 
opposed by the Government of the day. On September 6th, 1869, Lord Granville addressed a circular despatch to the colonies dissociating himself from any connection with the propaganda of the Society, and strongly objecting to any collective representation of the Colonial Empire in London.

If Mr. Gladstone and Lord Granville accepted with caution and reserve the policy which the Colonial Institute was founded to advocate, it was not long before the swing of the pendulum acquired such strength as to make the policy a dominant issue in the party politics of the day. As Lord Morley has declared in his Life of Gladstone, it was at the Crystal Palace on Midsummer Day, I872, that Lord Beaconsfield struck the first note of the new imperialism. He confessed that he had been so far caught by the subtle views of the disintegrationists that he thought the tie was broken. Opinion in the country was at last rising against disintegration. The people had decided that the Empire should not be destroyed. The creed of the new policy was to be "the maintenance of our institutions, the preservation of the Empire, and the improvement of the condition of the people." A longer quotation from this speech than Lord Morley allowed himself may well be placed on record.

"If [said Lord Beaconsfield] you look to the history of this country since the advent of Liberalism forty years ago, you will find there has been no effort so continuous, so subtle, supported by so much energy, and carried on with so much ability and acumen as the attempts of Liberalism to effect the disintegration of the Empire of England. And, gentlemen, 
of all its efforts this is the one which has been the nearest to success. Statesmen of the highest character, writers of the most distinguished ability, the most organised and efficient means have been employed in this endeavour. It has been proved to all of us that we have lost money by our Colonies. It has been shown with precise, with mathematical demonstration that there never was a jewel in the crown of England that was so truly costly as the possession of India. How often has it been suggested that we should at once emancipate ourselves from this incubus? Well, that result was nearly accomplished. When those subtle views were adopted by the country under the plausible plea of granting self-government to the Colonies, I confess that I myself thought the tie was broken. Not that I, for one, object to self-government. I cannot conceive how our distant Colonies can have their affairs administered except by self-government. But self-government, in my opinion, when it was conceded, ought to have been conceded as part of a great policy of Imperial consolidation. It ought to have been accompanied by an Imperial tariff, by securities for the people of England for the enjoyment of the unappropriated lands which belonged to the sovereign as their trustee, and by a military code which should have precisely defined the means and the responsibilities by which the Colonies should be defended, and by which, if necessary, this country should call for aid from the Colonies themselves. It ought, further, to have been accompanied by some representative council in the metropolis which would have brought the Colonies into constant and con- 
tinuous relations with the home Government. All this however was omitted because those who advised that policy,- - and I believe their convictions were sincere-looked upon the Colonies of England, looked even upon our connection with India, as a burden on this country, viewing everything in a financial aspect, and totally passing by those moral and political considerations which make nations great and by the influence of which alone men are distinguished from animals.

"Well, what has been the result of this attempt during the reign of Liberalism for the disintegration of the Empire? It has entirely failed. But how has it failed? Through the sympathy of the Colonies with the Mother Country. They have decided that the Empire shall not be destroyed; and in my opinion no Minister in this country will do his duty who neglects any opportunity of reconstructing as much as possible our Colonial empire and of responding to those distant sympathies which may become a source of incalculable strength and happiness to this land."

The new imperialism required a new colonial policy. The logical consequence of Lord Russell's policy of preparation for a time when our colonies might with propriety be severed from us and formed into separate and distinct States in alliance offensive and defensive with this country, was that it became the duty of the Colonial Office to provide each of the colonies with an adequate political equipment, and to help to train them, through these agencies, into a capacity for self-government. The new imperialism required a modification of this policy. Its aim was 
to make every colony a connecting link in the chain of the Empire.

It had to recognise the results of the earlier policy in the demarcation of two groups of colonies: the colonies which had been trained into a capacity for self-government and those colonies which were under the direct control of the Imperial Government ; in other words, between self-governing and Crown colonies. This distinction required a complete reorganisation of the Colonial Office, first in its relations to the self-governing colonies as virtually independent States, and, secondly, in its relations to the Crown colonies, for each of which it had to find an appropriate political, social, and industrial equipment.

I may now proceed to give some account of the operation of the new policy in the Crown colonies. 


\section{CHAPTER VI}

\section{THE COLONIAL OFFICE}

THE Colonial Office is a system including five bodies, each revolving, in a sense, on its own axis round the central force of the Secretary of State. These bodies are the Establishment, the Office of the Crown Agents, a nebulous body of agencies connected with the system through the officer holding the appointment of Medical Adviser, the Royal Botanic Gardens at Kew, and the Imperial Institute.

Under the designation of Establishment I include the permanent staff of the Office. In considering the appropriate functions of the Establishment we must bear in mind that for decades our colonial policy had for its aim to supply the colonies with a constitutional apparatus, to educate them in political methods, and to provide them with an equipment of political leaders and departmental officials with a view to their ultimate separation as independent States. It was of the essence of this policy to reproduce in every colony the spirit and form of our institutions, and, as the principles of the political institutions of the State were held to be inalienable from the principles of the religion of the State, it 
formed a part of the Colonial Office policy to bring within the sphere of Protestant influence, as a political agency, the people of every race, alike those who had a religion and ethical code of their own and those who had none. Thus it may be said that questions of political administration occupied practically the whole area of activity of the Colonial Office. The doctrine of laisser faire and individualism in respect of all other departments of human activity dominated the Office. While the functions of the Colonial Office were thus limited, the Establishment was conveniently grouped into sub-departments dealing with groups of colonies according to their geographical distribution. All departmental work has a tendency to be carried on in "water-tight compartments." But this did not seriously interfere with the work of the Colonial Office, so long as it served only to concentrate the doctrines of the policy of the day and bring them to bear on the concrete exigencies of the colonies. The policy being one, it was an advantage that each department should devote itself exclusively to bringing it to bear on the particular circumstances of the colonies within its sphere of work.

During the period of this policy the Colonial Office was a self-contained administrative Department, its functions being limited to controlling and advising the local colonial Governments in the exercise of training themselves into a capacity for self-government. Had Lord Russell's policy been carried to its logical conclusion, and the colonies become a system of allied States, the relation of the Colonial Office to the colonies would have been 
gradually converted into a relation closely analogous to the relation of the Foreign Office to foreign governments. It must be my endeavour to show the evolution of a process that led to a bifurcation of the functions of the Colonial Office in two directions, one leading to a system of friendly relations with the self-governing colonies as virtually independent States, the other to a new system of administrative control over the Crown colonies.

Our colonial policy has passed through three well-defined stages. In the first the colonies were left free to govern themselves, but their commerce was made completely subservient to the interests. of the mother country. In the second, having, by tampering with their internal affairs, lost the North American provinces, we sought to hold our colonies more firmly by governing them from home. In the third, we made it our aim to provide them with Constitutions with a view to their ultimate separation as independent States.

In all the earliest possessions of the Crown the constitutional establishment was formed after the model of the mother country, and consisted of an Executive Council and Legislature of two Chambers, one nominated, the other elected. Under this form of Constitution the colonies had been allowed selfgovernment in local affairs, but their trade was limited by the strictest control and made subservient solely to the interests of the mother country. This form of Constitution, and the policy it represented, continued to the secession of the North American provinces as the United States of America, and it is easy to see now that while the form of the 
Colonial Constitution resembled that of the mother country, it differed in the essential particular that the Executive and its officers were immovable and independent of the Legislature. They were the servants of the Colonial Office, bound to enforce its policy by the necessary legislation, and give effect to it through the agency of departmental rules and regulations, their executive functions being expressly reserved from the interference of the Legislature and subject to the control of the Colonial Office.

The history of the constitutional development of the self-governing colonies is the record of a struggle for emancipation from this control of the Colonial Office. The secession of the North American colonies was followed by a change in our colonial policy, prompted by a determination to prevent the other colonies from following their example. While therefore the form of the Constitution was retained in the remaining colonies, and even introduced into Canada by the Act of 1791 , the power of the Executive to control the Legislature was extended from matters of external commerce to domestic concerns. The colonies acquired immediately after the secession of the United States were gained by conquest, and the form of government adopted was the combination of administrative and legislative powers in the Governor aided by a Council of official advisers.

The evolution of the political constitutions of these colonies shows well marked stages of development. We have in the earliest stage a Chief Executive Officer, styled Governor, or Administrator, or Com- 


\section{I74 THE BROAD STONE OF EMPIRE}

missioner, assisted by two or more official councillors nominated by and responsible to the Crown and entrusted with administrative and legislative functions. In the next stage we have the administrative and legislative functions separated by the creation of an Executive Council and a Legislative Council, all the members of both Councils being nominated by the Crown. In Legislative Councils of this stage usage has led to a gradual process of development, marked by an increase of the nominated members to represent a larger area of interests. This is well illustrated in the case of the Australian colonies. In New South Wales, for example, the Council, limited to not less than five nor more than seven persons by an Act of I 823 , was by an Act of 1828 enlarged to a Council of not less than ten nor more than fifteen members. The next stage was the creation of a Council consisting of twenty-four, thirty-six, or some similar number of members, of whom one third was nominated by the Crown, and two thirds were elected by constituencies. This form of representative government was first set up in New South Wales by an Act of 1842 . By an Act of i 850 , entitled "An Act for the better government of Her Majesty's Australian Colonies," provision was made for enabling them to pass on to the final stage of responsible government, exercised by a Governor and Executive Council, a Council, and a Legislative Assembly. The Act of I850 was drafted on a report of the Committee of the Council of Trade and Foreign Plantations, approved by the Queen in Council in May, I849. As already related, to the ordinary members 
of the Board of Trade had been added for the occasion Lord Campbell, Sir James Stephen, and Sir Edward Ryan, and, although the phrase is getting hackneyed, I venture to call the report an epoch-making period in the constitutional history of our colonies. Lord John Russell, in introducing the Act, declared its objects to be to train the colonies into a capacity to govern themselves, and the reasons in favour of combining in a single Chamber the popular element and the required check were fully discussed by Earl Grey. A principal reason was the difficulty of finding in young colonies the elements necessary for a Second Chamber in substitution of the House of Lords. It was admittedly an Act designed to prepare the way for selfgovernment, and the clearest proof of this is that it contained provisions enabling the local legislatures to reform their own Constitution subject to approval by the Imperial Parliament. It has served as a model after which, with many important modifications designed to meet local circumstances, all the Single Chamber Constitutions since established in British colonies have been fashioned.

It is not necessary for me to follow the history of the last stage of constitutional development in the colonies now having a responsible government, the subordination of the Executive to the Legislature. Before i 860 eight colonies had received responsible government ; the Cape was added in 1872 , Western Australia in I 890, Natal in 1893 , and the Transvaal and Orange River Colony in 1906. Thus the circle of our self-governed colonies in the temperate zones was complete. In 1867 the Dominion of Canada 


\section{I76 THE BROAD STONE OF EMPIRE}

was constituted by the British North America Act, and in 1900 the Commonwealth of Australia by the Commonwealth of Australia Constitution Act. The South African colonies have been unified by the Act of 1909 .

But coincidently with the gradual emancipation of the self-governing colonies from the control of the Colonial Office, experience was proving that our tropical colonies do not contain the essential elements necessary for the stability of responsible government and that these elements cannot be supplied by any political agency. The functions of the Colonial Office had therefore to be enlarged to meet the exigencies of a new system. It had in the first place to equip the Crown colonies, not with a uniform type of Constitution which should serve as a bridge to the responsibilities of self-government, but with Constitutions adapted to communities of varying capacities having only this in common that they admittedly did not possess the conditions necessary for self-government. How such Constitutions were provided must form the subject of a separate chapter.

But the Colonial Office had much more to do. It had to readjust its relations to the Crown colonies, and to extend itself in a new area of activity. For, while the gradual development of the system of self-governing colonies was modifying the relation of the Colonial Office to those colonies, the relation of the Colonial Office to the Crown colonies was being modified by other causes.

These causes may conveniently be summed up in a phrase, the struggle of the nations of the northern 
temperate zone for the control of the tropics. The story of an early stage of the struggle in the United States has already been told. It was a direct consequence of the result of their civil war, the war itself having been in its final analysis a conflict for the control of the sub-tropical area of the United States. There followed the creation of a United Germany, and the expansion of French, German, and American colonial enterprise, in jealous rivalry for the control of the tropics on the principles of a rigidly exclusive monopoly.

The following tables conveniently illustrate the struggle of these Powers for the command of colonial territory during the last quarter of the nineteenth century :

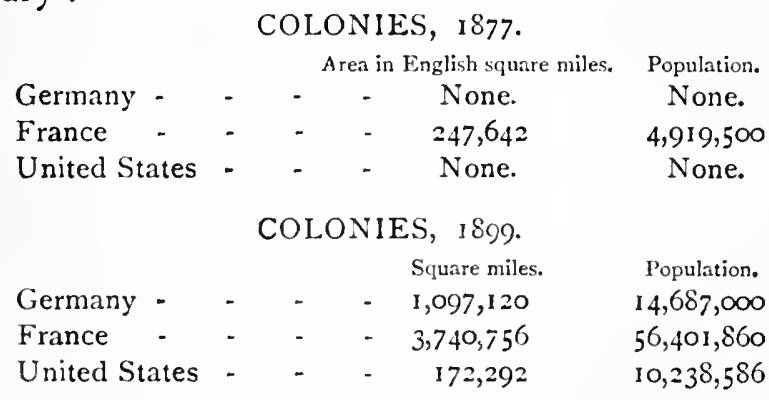

These striking figures should be read in the light of the fact that the three great trading nations concerned are all strongly protectionist, while our commercial policy is that of "the open door."

Coincidently with the struggle, and largely consequent on it, there pressed to the front with increasing urgency grave economic problens arising out of the internal conditions of this country, until we had to meet the exigencies of a population of over 42,000,000 persons, constantly demanding new 


\section{I78 THE BROAD STONE OF EMPIRE}

sources of supply and new areas of activity for the forces generated by the progress of industry and the growth of commerce.

History will award to Mr. Chamberlain the credit of being among the first to realise that in these circumstances the economic salvation of the United Kingdom must be looked for in our undeveloped estates in the tropical regions of the earth, while he was certainly the first Colonial Secretary to build a constructive policy on the foundations of this faith.

By education and official experience the body of men who formed the Establishment of the Colonial Office, when Mr. Chamberlain became Secretary of State, were, as a rule, perfectly qualified to advise him on the political and administrative business of the department. But Mr. Chamberlain saw clearly that if his policy was to be successful it must be carried out by methods appropriate to a time when science has placed at the disposal of man capacities not available during the previous history of our colonisation, and that the new era of activity demanded a new range of qualifications.

Consequently, the Colonial Office had to supply the Crown colonies with an equipment of heads of departments qualified to carry out the new system and to provide agencies by which every department might be kept abreast of the steady progress of science. These agencies have been already designated as the Crown Agents' Office, the Medical Department, the Royal Botanical Gardens at Kew, and the Imperial Institute. They will be dealt with in later chapters. In the meantime, however, it will be convenient to carry on the narrative of 
further changes in the organisation of the Colonial Office in its relation to the self-governing and Crown colonies respectively.

The South African War marked an epoch in the history of the Empire. Centuries of political development in America had federated the Canadian colonies of British and French origin not, as anticipated by Lord Durham, into a nation under British ascendancy and supremacy, but into a nation under French ascendancy but British supremacy. A single century of colonisation from the date of the first British settlement had federated colonies of British settlers in Australia and New Zealand into nations under British ascendancy and British supremacy. A few years of war federated colonies of British and Dutch origin in Africa into a nation under Dutch ascendancy but British supremacy. And while the causes and consequences of the South African War were exasperating public opinion and dominating party politics, the expansion of the British Empire in tropical Africa, outside the area of the South African colonies, was going on with little observation by a process analogous to that of the coral insect. While the South Africa Union has an approximate area of 475,000 square miles, with an estimated population of a little over 5,000,000, the Crown colonies in Africa have an area of over I,600,000 square miles with an estimated population of nearly $30,000,000$ of inhabitants.

The administration of this vast area of Africa, including populations of the most diverse elements and territories of the most varied resources, was imposed upon the Colonial Office, in addition to the 


\section{I80 THE BROAD STONE OF EMPIRE}

already heavy burden of its direct responsibilities, including in America the West Indies, in Asia Ceylon, Hong Kong, the Straits Settlements, and the Federated Malay States.

Professor Osler, Regius Professor of Medicine at Oxford, in the course of an Address to the London School of Tropical Medicine on October 26th, 1909, exhibited the following table, giving the present population and area in square miles of our tropical possessions compared with the tropical possessions of France, Germany, and the United States. It illustrates the result of the conflict for the control of the tropics.

\begin{tabular}{|c|c|c|c|c|c|}
\hline & \multicolumn{4}{|c|}{ Tropical territory in } & \multirow{2}{*}{$\begin{array}{c}\text { Total } \\
\text { tropical. }\end{array}$} \\
\hline & America. & Africa. & Asia. & Pacific. & \\
\hline France & $\begin{array}{r}440,000 \\
35,000\end{array}$ & $\begin{array}{r}17,700,000 \\
4,0,32,000\end{array}$ & $\begin{array}{r}18,500,000 \\
310,000\end{array}$ & $\begin{array}{r}80,000 \\
9,000\end{array}$ & $\begin{array}{r}36,720,000 \\
4,386,000\end{array}$ \\
\hline$\underset{\text { Empire }}{\text { German }}\{$ & Nil. & $\begin{array}{r}11,700,000 \\
931,500\end{array}$ & Nil. & $\begin{array}{r}400,000 \\
96,000\end{array}$ & $\begin{array}{r}12,100,000 \\
1,027,500\end{array}$ \\
\hline $\begin{array}{l}\text { United } \\
\text { Kingdom }\{\end{array}$ & $\begin{array}{r}2,000,000 \\
109,000\end{array}$ & $\begin{array}{r}30,500,000 \\
1,600,000\end{array}$ & $\begin{array}{r}296,600,000 \\
1,900,000\end{array}$ & $\begin{array}{l}\text { I, I } 50,000 \\
1,400,000\end{array}$ & $\begin{array}{r}330,250,000 \\
5,009,000\end{array}$ \\
\hline $\begin{array}{l}\text { United } \\
\text { States }\end{array}$ & $\begin{array}{r}305,000 \\
47,500\end{array}$ & Nil. & Nil. & $\begin{array}{r}7,707,000 \\
134,500\end{array}$ & $\begin{array}{r}8, \text { OI } 2,000 \\
\text { I } 82,000\end{array}$ \\
\hline
\end{tabular}

Upper lines give population. Under lines give area (in square miles).

The tropical world has been appropriated, and this country has a burden of tropical population six times as great as the other three combined. A few comparatively small districts remain either independent, or as yet unexplored, as Abyssinia and parts of Polynesia.

No wonder that there forced itself to the front the question whether the Empire had outgrown its 
organisation. The sundry and manifold relations existing between the Colonial Office and the component parts of the Colonial Empire had not failed to invite attention to the question of Imperial organisation, and under this rubric Sir Frederick Pollock and a group of influential friends, including Mr. Haldane, proposed in 1905 the creation of an Imperial Committee of the Privy Council, to include representatives of all the self-governing colonies, who would thus have an opportunity to share in the councils of the Empire. This proposal had mainly to do with the self-governing colonies, and I need not discuss it. I allude to it only as a public recognition by men of eminence and experience of the necessity that had arisen to lighten or readjust the ever-increasing burdens of the Colonial Office. The question of the relations of the Office to the Crown colonies was of more pressing importance, having in view the enormous expansion of the area of responsibilities of the Office and the nature of the duties imposed upon it.

On December 5th, 1905, there was published in The Times an article on administrative reform in the Crown colonies, insisting on some defects of the existing system and proposing a remedy. It acquired additional importance from a letter published on December 26th, in which Sir Augustus Hemming, who had served for thirty years in the Colonial Office and subsequently as Governor of two Crown colonies, associated himself with the premises and conclusions of the article. The Times declared that the administration of the Crown colonies in the Colonial Office was managed by 
junior clerks, and Sir Augustus Hemming stated that these officials obtain a much larger portion of authority and control than their position properly justifies. "These men," he wrote, "have not, and cannot have, the knowledge and experience required for such duties; and it is naturally galling to high officials in the colonies to know that their suggestions are criticised by youths almost fresh from school or college, and their mature and well-weighed advice possibly rejected on the recommendation of these embryo statesmen." Another ground of complaint urged was that there was no continuity, but rather a constant interruption and reversal of policy. No one who has had long experience of the Colonial Office, from within or without, could be ignorant that these complaints were not new. Seventy years ago Sir Henry Taylor, speaking with intimate knowledge from within, declared that the far greater proportion of the duties performed in the Office were performed under no effective responsibility. The whole history of the Office is a record of conflicts with the ablest, and even the most trusted, of grovernors; and these conflicts have been largely exasperated by the causes indicated.

The question of administrative reform in the Crown colonies could not fail to interest many who had, like myself, had a long and intimate experience of colonial administration. It seemed to me, therefore, that I should be justified in placing the results of my experience at the disposal of the Secretary of State, and this I decided to do at once. I addressed a letter to the Colonial Office in which I frankly stated my views. 
December 8th, 1905.

If any apology is necessary for the course I have ventured to adopt in addressing this letter to you, I must ask you to find it in a Colonial service extending over six and thirty years, during which I have held high administrative and executive posts in tropical Crown Colonies, and have been fortunate enough to obtain the confidence of a long line of Secretaries of State.

I desire to submit, for the consideration of the Colonial Office, some observations on a scheme of Administrative Reform in the Crown colonies, an account of which was published in 'The Times' of

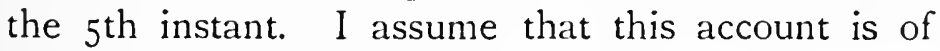
authorised or authentic origin.

Briefly, the scheme of reform contemplates the appointment of Governors-General for groups of tropical colonies, who will spend the unhealthy season in England and 'the relatively healthy season,' -in many tropical colonies the most enjoyable climate in the world-within their Government. From the point of view of the health and comfort of the Governor-General I admit the scheme to be admirable, and the same may be said of the pecuniary interests of the Governor, who will draw his full salary while relieved from many of the burdensome conditions inseparable from his position within his Government.

The other advantages claimed for the scheme are continuity of policy, facilities for the development of industries, and the substitution of responsible officers at the Colonial Office for the administration of the affairs of the Crown colonies by junior clerks. 


\section{I84 THE BROAD STONE OF EMPIRE}

As regards continuity of policy it is stated that often enough Governors succeeding each other in rapid succession find themselves in complete disaccord with the policy of their immediate predecessors. The result, when the term of service is short, is that the whole of one man's administration may be spent in reversing the decisions of the previous administration, which again may occupy the greater part of the term of his successor to re-establish.

This is surely the most formidable indictment against the administration of the Colonial Office ever presented; and we are told that this result has followed 'one of the wisest traditions of the Colonial Office to maintain in the most absolute manner the responsibility of the Officer Administering the Government so long as he retains the confidence of the Crown.'

I need hardly remind you that within the last few years Mr. Chamberlain has pointed out that, however exasperating a colonial Administrator, devoted heart and soul to the interests of his Colony, may find the interference of the permanent officials of the Colonial Office, it is the paramount duty and function of the Office to secure a continuity of policy, and a proper adjustment of local interests to imperial exigencies. To reconcile these sometimes conflicting interests and exigencies $\mathrm{Mr}$. Chamberlain declared to be the supreme function of the Colonial Office. Mr. Balfour spoke in the same sense at a banquet given to Mr. Chamberlain on June 3oth, 1904. The principle thus indicated seems to be the bed-rock of the system of Crown Colony Government. 
We are now told that the administration of the Colonial Office has been governed by a 'wise tradition' inconsistent with this principle, and carried so far as to result in a constant interruption and reversal of policy.

I feel bound, however, to declare my conviction that so far as concerns the operation of this 'wise tradition' the statement is misleading. I believe that the records of the Colonial Office can show that, sometimes to satisfy the caprice or idiosyncrasies of Colonial Office clerks, more often, I am willing to believe, for political reasons, oftenest, I hope, on grounds of a comprehensive imperial policy, the action of trusted colonial Governors has been constantly modified in a manner quite inconsistent with the absolute maintenance of their responsibility.

I was not aware that interruption and reversal of policy in the Crown colonies had been carried so far as I now learn. But I was aware that it had been carried far. There are Governors who seem to object on principle to everything their immediate predecessor has done, and to whom the mere mention of their predecessor's name is as a red rag to a bull.

But surely it has been, as I have indicated, the primary duty of the Colonial Office to regulate the disorders that might arise from such eccentricities, by the obvious course of not allowing a Governor to reverse the policy of his predecessor, approved by themselves, until the predecessor has had an oppor. tunity of explaining and defending his policy. I have long been of opinion that to ensure continuity of policy it is desirable to create a purely advisory Council on the lines of the India Council, on which 
retired Governors would have an opportunity of giving their views on proposals to reverse their policy. The appointment of members for not more than three or five years would prevent such a Council from becoming superannuated.

It is not easy to understand how the system now proposed can promote a continuity of policy. If the check over a Governor now provided by the functions of the Colonial Office, as indicated by Mr. Chamberlain, has failed, is it conceivable that it can be strengthened by substituting the Governor himself for the office whose constitutional duty it is to control him?

I pass on to the question of facilities for the development of local industries, and the powerful and competing interests at home which insist that the consideration of the Imperial authorities shall be accorded to their views. I am sure I shall not be suspected of underestimating the importance of this subject. The Duke of Marlborough did me the honour of presiding at the Colonial Institute when I dealt largely with it.

But in the development of the Crown colonies there are two interests concerned,-Home and Colonial. Hitherto it has been considered the duty of the Governor to devote himself to the study of everything that concerns local interests, local conditions, local exigencies, local wishes, and to collect and co-ordinate all the information he has unrivalled means of obtaining for the Secretary of State, who, on the advice of the experts of the Board of Trade, (including, of course, the Imperial Institute) and Kew Gardens, or other home authorities, is able to 
hold an even balance between the local interests of the Colony and the powerful and competing interests at home. This alignment of duties between the Colonial Office and the colonial Governor rests on the same bed-rock as the principle I have referred to in discussing the question of the continuity of policy.

If I may be allowed to make a suggestion with a view to securing an adjustment of the conflict between the old traditions of the service and the new conditions forced upon the Secretary of State, I believe it will have to be found in a re-organisation of the Colonial Office into two branches, or subdepartments, one dealing with questions of politics and administration,-I may say with all those affairs which up to a comparatively recent date constituted nearly the whole body of Colonial Office businessand the other dealing with the development of the material resources of the colonies.

The training and experience of the present permanent officials qualify them very well to deal with the former class of business; but if we are to compete successfully with foreign colonial enterprise, it is certain that in the latter sub-department every question will have to be dealt with on the principle of applying to even the commonest of them the last results of scientific research.

I hope I may say, with all respect for the permanent officials of the Colonial Office, who have been my life-long friends and colleagues, that such questions lie altogether outside their competence, as they lie equally outside the competence of a colonial Governor whose duties require quite other qualifications. The higher appointments in this sub- 
department will have to be filled by men of the first scientific attainments.

Such a re-organisation would draw a distinct line between the work of a sub-department in which the officials may at any moment have to adapt themselves to a change of Government, and a sub-department in which no change of Government can in any way affect the operation of the natural laws which regulate the concerns with which they have to deal. It would, of course, have to be carried out in detail so as to put an end to the deplorable, but apparently admitted, system of government by junior clerks.

But I cannot find in such a scheme, any more than in the proposals now made, any place for a responsible Governor, if, indeed, the presence of a responsible Governor, in any intelligible interpretation of the term, in the Colonial Office is consistent with the constitutional position of the Secretary of State.

It is, however, distinctly stated that the Governor-General, whether in England or in his colony, will remain always personally responsible for the administration of his government. I am unable to understand how this is possible. The duties of a Governor require his decision on a perplexing amplitude of subjects every day. It is impossible to say that in the course of any day a question may not arise of the gravest consequence, on which a decision must at once be arrived at. The general work of a Governor, may, perhaps, be classified as administrative and political. Except in colonies such as Ceylon and the Straits Settle- 
ments, where the qualification and status of the Civil Servants are almost equal to those of the Civil Service of India, the administration of the Departments requires the constant supervision and control of the Governor. Questions between the Departments and the public crop up every day, and decisions on them are often statutory obligations on the Governor. Who is to be responsible? I observe that one of the duties to be discharged by the Governor-General at the Colonial Office is to submit the annual budget and annual accounts, and give all explanation required as to revenue and expenditure. The preparation of the annual budget is one of the chief duties of the year, and requires a careful consideration of every detail, and of the reasons which justify the Heads of Departments in fixing their expenditure and revenue. I venture to believe that no such financial statements can be prepared or explained by any Governor without reference to Heads of Departments, and the documents which they have in their possession. If these transactions are to be considered verbally between the Governor, advising on such knowledge of a host of details as he can carry in his head, and the Secretary of State, there will be no record, and only endless confusion will be the result. Political questions arise every day. The most important are, of course, those that affect the interest of different sections and classes of the community. Disturbances such as are going on at this moment in Georgetown, British Guiana, generally have their origin in questions of this nature. It may well be said that to avert such disturbances, which can only 


\section{I90 THE BROAD STONE OF EMPIRE}

be done by the personal influence, tact, judgment and sympathy of the Governor, is amongst the most urgent of his duties; and the necessary influence can be gained in no other way than by daily and hourly devotion to the interests of the colony in a spirit of impartial justice to every class of the community. How is a Governor-General at the Colonial Office to acquire such influence, and if disturbance takes place, who is to be responsible for it? It is a mere truism to declare that the Governor of a tropical colony should be selected with a view to his qualifications to act in moments of difficulty and emergency. Such moments occur without notice, and the issue depends entirely on the man on the spot. Whatever may be the qualifications of the man in Downing Street he is absolutely powerless, and it is difficult to understand in what sense his responsibility can be maintained. Then, again, there are questions connected with the administration of justice. Who is to be responsible for the most sacred of all duties, - the exercise of the clemency of the Crown?

Space forbids me to dwell on many other obvious difficulties, but taking a broad view of the question, is it really conceivable that the duties of the Viceroy of India could be carried on by him in London? I believe it is expressly provided by Statute that his tenure of office is limited to his presence in India. And surely the principle applies to the Sovereign's representatives in the colonies.

If the Governor-General in London is to be absolutely responsible, what is to be the nature of the responsibility of his deputy,-for I presume 
there must be a deputy-in the colony? What are to be the terms of the divorce in his case between authority and responsibility?

I observe that much has been said on the question of health, but what has been said applies to nearly the whole Civil Service of India. It is certain that the work of the tropics must be carried on in the tropics, and I find it difficult to understand how any Englishman could consent to accept the appointment of Governor-General on conditions which would relieve him from the inconveniences and possible risk borne with cheerful courage and constancy by every one of his subordinates.

All men have not the qualities of Chinese Gordon, but what would he, or any one of the great administrators who have established our tropical Empire, have thought of such a proposal?

I have, etc.

In due time I received the following reply:

Downing Street,

Sir, I 7 th April, I 906.

I am directed by the Earl of Elgin to convey to you his Lordship's thanks for your letter of the Sth of December last, on the subject of the administration of the Crown Colonies, and to inform you that in dealing with this question he has derived valuable assistance from your observations, which embody the result of a long and varied experience of Colonial administration.

$$
\text { I am, etc., }
$$

R. L. Antrobus. 


\section{THE BROAD STONE OF EMPIRE}

Lord Elgin's tenure of office was not very long, but it covered a period into which many events of far-reaching importance were crowded. In respect of the administration of the Crown colonies, certainly not the least important part of his work was concerned with a revision of the Rules and Regulations for His Majesty's Colonial Service, and some changes in the internal organisation of the Colonial Office. Although the Rules and Regulations have been published annually for many years as a "revised edition," the first chapter has been prefaced by an intimation that it was largely obsolete. The remaining nineteen chapters have long been partly obsolete, partly superseded in different colonies by Letters Patent, Orders in Council, Legislative Enactments or Instructions. They were inevitably a constant source of discussion in the Office, and of angry controversy in the relations between the Office and the colonial Governments. I may give an illustration. Some years ago one of the most distinguished members of the clerical staff wrote to me that he had been placed in charge of the department in which my Government was included. He told me that for some time the department had been in the hands of the junior clerks but that he proposed to manage it himself. Accordingly he set to work to do so conscientiously in accordance with the Rules and Regulations, many of which had become obsolete by the introduction of steam communication and other not very modern arrangements. The consequences were extremely inconvenient, and they first suggested to me a reform which I have ever since advocated; the appointment of an 
advisory Council at the Colonial Office, on the lines of the India Council. The revision of the Rules and Regulations relieved the Colonial Office of a source of controversy which had long been a public scandal. The other changes introduced by Lord Elgin were rather of the nature of a modus vivendi between the existing organisation of the Office and the appointment of an advisory Council. They admitted a system of mixed committees including experts to advise on matters within the competence of the Establishment and the other departments of the system.

By aid of advisory Committees the Office is supplied with expert knowledge in every branch of its activity; but the problem of applying this knowledge to the special needs of Colonies presenting an almost infinite diversity of local environment is still unsolved. In my opinion it is only to be solved by an advisory Council of members, of both long and recent practical experience in the principal colonies or groups of colonies. Such a Council has been advocated by many experienced administrators and others who have made imperial organisation the subject of study for years.

Lord Elgin's reforms have been followed by a very important change, introduced by Lord Crewe; the organisation of a separate department of the Office, designated the Dominions Department, whose business it is to deal with all matters relating to the self-governing colonies. This significant measure seems to me to have cleared the way for the creation of an advisory Council to assist the Secretary of State in all matters relating to the Crown colonies. 


\section{I94 THE BROAD STONE OF EMPIRE}

In profession and doctrine it is admitted that in colonial and Indian affairs there should be maintained continuity of policy and uniformity of development. But in administrative practice many causes tend to interruption or reversal of policy. When the head of the Government is frequently changed it can hardly be otherwise. "There is a tendency," said an eminent member of the Bench, "in the mind of every judge, when he first sits in cases of appeal, to criticise and find flaws in the judgment of the inferior Court." And it is certain that judgments have been delivered in which such a tendency seems obtrusively, and even designedly, prominent. "I am not here," Lord Curzon is reported to have said, "to follow the experience of my predecessors, but to correct it." The anecdote may not be authentic, but it expresses a tendency to which governors are particularly liable. To use a familiar phrase, it may spring from a common desire to "go one better": it may have its origin in the noblest motives or the meanest; but the records of the Colonial Office can show that it is apt to run to excess with serious prejudice to the public service.

The difficulties of a governor finding himself in an entirely strange environment, and having to take over and administer a policy which he cannot at once understand, are great. It may be an excellent policy, adequate and appropriate to the political conditions of the place; and yet he may be disposed to condemn it as inconsistent with the political conditions of any environment of which he has had experience. And then it seems so easy for him to substitute something better, something more in 
accordance with principles and methods approved at home, something that he can set out in a despatch with a clear exposition of its intrinsic excellence, not seeing the ruinous consequences of a policy theoretically commendable and plausible, but fatal in its premature or inopportune application to local circumstances. So there comes a day when the Colonial Office has to decide between upholding the responsibility of the man on the spot and interrupting or reversing a policy. Such cases have often occurred in the past, and it is probable that they will occur still more frequently in the future, seeing the enormous expansion of the Colonial Office's area of jurisdiction in Africa and in the East, and the difficulty of finding administrators with experience of the diverse elements of the populations and the varied resources of the territories.

If I lay stress on the maintenance of a continuous policy, I bear in mind also that the justification of our claim to our large share in the control of the tropics demands a constant, steady, and uniform process of development. The questions that arise in the operation of this process are many and complex. Even those who take the most optimistic view of the future of the Empire must recognise the difficulty of questions concerning race and colour, the migration of labour, health, and the conditions under which the development of the natural resources of a tropical territory can best be carried on, to the mutual advantage of the local community and of the United Kingdom. Practically the whole vast area of the territories under the direct control of the Colonial Office, territories equal to the whole extent 


\section{I96 THE BROAD STONE OF EMPIRE}

of our Indian Empire, including the Native States, lies within the tropics; and in this area the relations of labour to capital have, in addition to other elements of conflict, a distinct cleavage in the fact that capital is European and white, labour African or Asiatic, and coloured. Out of these relations there arises a frequent conflict of interests, which it is the function of the Colonial Office to adjust in a spirit of equal sympathy with local and imperial exigencies. In this adjustment is to be found generally the origin of those grave differences between the central and the local government which, to the serious prejudice of the Empire, occasionally result in the resignation of the ablest and most conscientious of administrators.

I will indicate some of the advantages which may be expected to accrue to the Secretary of State from the creation of an advisory Council. In the first place, he will be informed of what is going on in his own office. There is not a nation in Europe whose history has not been affected by decisions arrived at by permanent heads of public departments without the knowledge of the Minister or responsible Chief, whatever his office may be called. If there is a tradition universally honoured in the domain of bureaucracy, it is that the Chief must only know what it is good for him to know. The late Mr. Grenville Murray illustrated the influence of the tradition in the inner working of Public Departments in France during the Second Empire and the Third Republic in his own picturesque style. In The Boudoir Cabal he described with equal felicity the inner life of a public office in England. The tradition was upheld in the 
Colonial Office for many years, during which grave inconvenience to the public service was caused by circumstances known to every member of the Office except the Secretary of State. It is physically impossible for a Minister to make himself acquainted with all the work of a great department, and the Office must decide to a large extent on what questions they may act without his direct authority under cover of his constitutional responsibility. Quite recently a great deal of light was thrown on this subject in the case of Adolf Beck, who had been the victim of a grave miscarriage of justice. The Home Secretary, during whose tenure of office the case was decided, had made a declaration in Parliament that no sentence passed by the Courts of Justice was ever reviewed without the full knowledge and by the direct authority of the responsible Minister. And yet, when Adolf Beck's case was the subject of public enquiry, it turned out that neither the documents nor the decision arrived at had been communicated to him.

But the tradition which prevents a Minister from knowing what is going on in his own office is prolonged into a wider area of activity, when the office claims, as it does, a rigidly exclusive monopoly of access to the Minister either by documentary or personal communication. There is some reason for this. The official and parliamentary duties of a Minister are so burdensome that his opportunities to grant personal interviews are extremely limited, and an interview is useless unless the Minister has had time to make himself familiar with the details of the question which it is proposed to discuss. Of the 
advantage of such interviews, when it is possible to accord them, there can be no doubt. I have in another chapter given an instance from my own experience in which a few words with the Secretary of State put him in possession of material facts, lost sight of in masses of correspondence, and enabled him to come to a prompt decision. Not many years have elapsed since one of the most distinguished of Colonial Governors of the Victorian Era, Lord Rosmead, was exasperated by the action of the Colonial Office into a determination to resign his appointment as Governor of the Cape. To a friend, concerned in the causes of the crisis, he said: "If you can see the Secretary of State himself, do so, but for Heaven's sake, don't attempt to argue with an Under Secretary or a clerk; you might just as well argue with a cauliflower." I hasten to add that this was not understood as a reflection on the ability of the Office but on the system. When Mr. Gibbon Wakefield was carrying on his long controversy on the art of colonisation with the Colonial Office, embodied as "Mr. Mothercountry," and when Mr. Charles Buller declared that every door of the Office should bear the inscription All hope abandon ye who enter here, it was not the personal ability of the permanent officials that he disputed. There has probably never been more conspicuous ability or devotion to the public service in the Colonial Office than when it was represented by Mr. "Over-secretary" Stephen and Sir Henry Taylor. What was deprecated was a system which placed in the hands of a group of officials, living in the artificial atmosphere of a public office in the centre of the Empire, absolute control 
over the destinies of communities living in the natural atmosphere of an essentially different environment between the centre and the circumference.

Such an advisory Council as I suggest would relieve the Minister of many demands for personal interviews by connecting the Office with an independent channel of communication between him and the colonial interests he controls and protects.

I am aware that in what I have said I may seem to lay myself open to a charge of attempting to throw discredit on the staff of the Colonial Office. That is far from my intention. Sir Frank Swettenham, in a chapter contributed to The Empire and the Century, has expressed a view in which I concur.

"It may be questioned whether the British people realise how admirably the work of the Colonial Office is done, how efficient is the staff of that department of the public service, and how much of the efficiency is due to the great qualities and the business-like methods of Mr. Chamberlain, who, during the eight years that he was Colonial Secretary, won for his office the admiration and respect of the Colonies to a degree never known before. The striking characteristics of the work done in Downing Street in its connection with the Crown Colonies are the patient care with which each question is examined and the anxiety to be just in every case, however great or however small the issue." $\mathrm{He}$ continues, however: "It is not suggested that the Colonial Office has arrived at perfection. Those who are under the Office, but not in it, would like to see a good many changes, both as to general 


\section{THE BROAD STONE OF EMPIRE}

principles and to the handling of details; and they could give excellent reasons in support of their view." 1

I will add that in times of stress and strain the staff have done their duty with a conscientious devotion to which not a few have sacrificed their health and their lives. But this does not alter my opinion that the administration of the Crown colonies requires knowledge which the staff cannot possess, and that the industry and ability of a permanent official may be a source of weakness rather than of strength to the Colonial Office. Every Secretary of State, however well-intentioned, energetic, and capable he may be, is likely, sooner or later, to become the medium, conscious or unconscious, through which the permanent heads of the Office will carry out their policy; and the greater the ability, industry, and enthusiasm of a permanent official the more likely he is to acquire over the mind of the Secretary of State the credit, the influence, and often the empire which is the result of untiring application and invincible fidelity. That is true of all departments of State, but in the Colonial Office special danger arises from the fact that the permanent official has no knowledge of the circumstances that differentiate the application of general principles to the environment of particular colonies. I will give an illustration. In reply to a proposal I received a despatch stating that the subject of my proposal had been thoroughly threshed out on a reference from another colony, and a copy of the despatch conveying the decision of the

1 The Empire and the Century, p. 885 (London, 1905). 
Office was enclosed for my guidance. I have not the slightest doubt that the question was threshed out with indefatigable care; but a decision admirable in the case of one Crown colony may be grotesque in the case of another.

It is in such cases that an advisory Council will give the Secretary of State the advantage of having both sides of a case pressed upon him. Instead of having only the case of the Office placed before him by able and trusted, but necessarily academic advisers, he will have at the same time the colonial case placed before him by advisers of practical experience. He will thus be kept informed not only of what is going on in the Office, but of what is going on in the colonies. Such an advisory Council would, in an appropriate way, take the place of the High Commissioners and Agents-General of the self-governing colonies. And, what is perhaps most important of all, the colonies will be assured that the decisions of the Secretary of State are really his own and not the decisions of a clerk. So long as the present system exists, the Secretary of State's despatches will always be assumed by the colonists to be the productions of junior clerks. That is not only the opinion of the colonists themselves. Sir Henry Taylor's Autobiography, and a continuous stream of literature on the subject, make it difficult to arrive at any other conclusion.

As regards the dignity and influence of the Colonial Office and its representatives in Parliament, the knowledge that the Secretary of State had at his disposal the collective experience of such 


\section{THE BROAD STONE OF EMPIRE}

a Council could hardly fail to inspire a larger confidence than at present exists. In order to create such a Council in analogy with existing bodies, my proposal is to include in it the Permanent and Parliamentary Under Secretaries, the legal adviser, and the heads of those agencies which constitute departments, or quasi-departments, of the Colonial Office system, and to associate with them a number of additional members selected on principles analogous to those which control the appointment of members of the Council of the Secretary of State for India. The tenure of office of these members should be limited to five years, with, possibly, a privilege of renewal as in the case of the India Council. It should be an absolute condition that members selected from the Colonial Service shall have held responsible office within the area of the Crown colonies for at least ten years. I may add, that, in my opinion, tenure of office in the Council ought not to exclude either permanent or additional members from appointment to the higher and highest posts as Governors or High Commissioners. Such Governors would carry with them into their governments qualifications of knowledge and experience such as few have hitherto possessed, and which would inspire with confidence the communities entrusted to their care. 


\section{CHAPTER VII}

\section{THE COLONIAL GOVERNOR}

I HAVE in the last chapter endeavoured to make it clear that there are inherent in the system of Crown colony government elements of conflict between imperial and local interests, and I have suggested that an advisory Council would be an instrument of conciliation. But, with or without such a Council, the Governor is and must remain the responsible intermediary between the Colonial Office and the local legislature of the Crown colonies. $\mathrm{He}$ is the representative of that control from which the American colonies could only emancipate themselves by secession, and from which the self-governing colonies have succeeded in emancipating themselves by the grant of responsible government. I propose before discussing the evolution of the Crown colony legislature to trace the evolution of the Crown colony governor. ${ }^{1}$

The exercise of the power of appointing colonial governors has passed through three principal periods. The American colonies included two groups, royal

${ }^{1}$ The history of the Governors in the English Colonies of North America is traced in elaborate detail by Professor E. B. Greene, of the University of Illinois, in his work, The Provincial Governors (London, I 898). 


\section{THE BROAD STONE OF EMPIRE}

and proprietary colonies. In the royal colonies the governor was appointed by the King in Council, usually on the recommendation of the Board of Trade; in the proprietary colonies by the proprietor, or proprietary company, subject to confirmation by the Crown. The claims of the Crown under the Stuarts to be the "sole fountain of honour and privilege" led to many conflicts, but resulted in a period during which the Crown exercised the absolute and undisputed power of appointing governors in all colonies. This period extended to very recent times. Since I 880 the Ministers of self-governing colonies have on two occasions refused to accept governors nominated by the Secretary of State. The result has been a period curiously analogous to the earlier period of royal and proprietary colonies. In the Crown colonies the governors are appointed by the Crown on the recommendation of the Colonial Office, which has succeeded to the powers of the Board of Trade; in the self-governing colonies governors are appointed by the Crown after the Colonial Office has ascertained that the appointment will be agreeable to the colony. Although the transition from one of these periods to another was gradual, each presents a well-defined landmark. In the patent granted to Sir Humphrey Gilbert in 1578 the right of government was given to the proprietor substantially without limitation. After a century of conflict, during the latter part of which the Committee of Trade and Plantations had exercised itself to bring the "Proprieties under a deeper dependence on the Crown," the Revolution of 1688 marked a 
new period. The great conflict between England and France for the possession of North America was just beginning, and a well-organised system of royal government was better adapted for such a struggle than an aggregation of royal and proprietary governments. A few years later the law officers advised that there was nothing in the charters that could "exclude your Majesty (who has a right to govern all your subjects) from naming a Governor on your Majesty's behalf, for those Colonies at all times." This declaration is significant as asserting within the field of colonial government that right of the Crown to govern all its subjects which in England had, during the Middle Ages, gradually been secured against the hostile forces of local privilege and feudal anarchy. It led to a logical conclusion in the Act 7 and 8 William the Third, which provided that all governors of Plantations should be approved by the Crown. The secession of the North American colonies confirmed the Crown in an absolute power of appointment in the colonies that remained, and in newly acquired colonies, for exactly a century, until in 1882 the absolute right of appointment was made subject to the assent of a self-governing colony.

Having now briefly traced the evolution of the prerogative of the Crown in the appointment of colonial governors, it may be interesting to take a survey of the social areas from which they have been selected. The selection of governors has naturally been modified by the three principal periods of imperial expansion,- - a period of exploration and conquest, a period of trade, and a period of beneficial 


\section{THE BROAD STONE OF EMPIRE}

occupation. Generally speaking, the appointment of governors during these periods has followed the line of progress of political power in England. During a period of exploration and conquest the navy and army offered the natural field of selection. During a period of trade the protection of the trade-routes required the same agencies, but the field of selection was enlarged to include the area of the origin of commerce, land and the profits of land accumulated in capital. The keynote of the enthusiasm which sustained Great Britain during the war with France and Spain for maritime and colonial ascendancy was trade. Commercial interests were the basis of colonial policy, the declared and only motive of imperialism in North America, in the Caribbean Sea, in Asia, and in the Indian Ocean. The selection of governors during the period of beneficial occupation of territories acquired during the preceding periods was modified by the colonial policy of the time. In the belief that the colonies were politically mischievous and commercially useless, it aimed at providing them with a political equipment, training them in the art of selfgovernment, and letting them go. The policy of the period was naturally dominated by a desire to substitute civil for military governors, and the most appropriate area of selection was found among professional politicians and in the higher ranks of the Home and Colonial Civil Service. The new area of selection produced a new class of governors, who came to be distinguished as professional governors. They were of two classes. The one class had risen through approved service in the adminis- 
trative departments and secretariats of colonies to the highest office in the Service. The other consisted of men who, in virtue of social influence or political services, were appointed to the highest office without experience in the lower stages of colonial administration. In either case a colonial career was a profession; and as those who entered on it were mainly or wholly dependent on the emoluments of their office, the privileges of the Civil Service in respect of pensions and retiring allowances were extended to governors by the Governors Pension Act, I 865 , modified by subsequent enactments. The position of colonial governors who had risen to office through administrative service in the colonies was materially modified by the new imperialism which, after I868, abandoned the policy of laisser aller and strained every nerve to associate the selfgoverning colonies with the Empire as practically independent nations under the supremacy of the Crown. From this time there dates a clear line of demarcation between the area of selection of governors of the self-governing and the Crown colonies respectively. While the governors of the latter have been generally taken from the professional class, those of the former have been thus picturesquely described by Mr. J. Collier, in an article in Macmillan's Magazine for November, 1903, on the "Evolution of a Colonial Governor."

"In the second half of the sixteenth century, when the greatness of its colonies was beginning to be recognised, the Spanish Government made a new departure by reflecting on its colonial governors the growing splendour of the monarchy, and hence- 
forth sent out to South America viceroys of exalted rank,-grandees of Spain, dukes, marquises, and counts, who had a viceregal court, a palace, and a body-guard. More than three centuries later, by deliberate or unconscious imitation, a similar change was brought about in the British Empire. In I874 the most ostentatious of British Prime Ministers inaugurated the new Imperialism by announcing in his magniloquent language that only those would in future be appointed colonial governors who had been 'born in the purple' like the Byzantine emperors. Then descended on the delighted colonies a flight of marquises, earls, viscounts, and barons, many of whom had no natural or acquired qualification for the post other than the English, Scottish or Irish handle to their names which procured them the appointment."

However unfortunate may have been some of these selections, the policy which dictated them found its highest and most legitimate expression in the appointment of the Duke of Argyll to be Governor-General of Canada in 1878 . It may well be that before long that experiment will be repeated by the appointment of members of the Royal House to be Viceroys of Canada, Australia, South Africa, and perhaps New Zealand. In the meantime, the policy of appointing peers to be colonial governors has been limited. In Canada the provincial lieutenant-governors are appointed from among the colonists; the same course will probably be followed in the subordinate governments of the Commonwealth of Australia, where reductions have already been made in the salaries of office, and the 
holders include admirals, generals, and civilians of lower rank than peers. The unification of Africa has led to the same result as the federation of Canada.

In the Crown colonies the appointment of professional governors, in the sense of officials of administrative experience, has now become the rule rather than the exception. For this there is good reason. I have dealt in a preceding chapter with the exigencies of Crown colonies which no accident of birth or fortune, but only the personal qualifications of the man can satisfy. "In the Army in war," said Napoleon, "the men count for nothing, the man is everything." So it may be said of the Crown colonies generally, and more especially in the new area of expansion in Africa; in times of emergency the Colonial Office is nothing, the man on the spot is everything. The appointment of the man on the spot equipped with the needful qualifications has been the problem of centuries. In the management of colonial affairs during the eighteenth century the Colonial Office was preceded by the Board of Trade, which had its origin in a Commission issued by the Crown in 1696 , after a varied experience of companies and committees charged with the care of the colonies. A Board of Commissioners was then organised "for promoting the trade of the Kingdom and for inspecting and improving $\mathrm{H}$ is Majesty's Plantations in America and elsewhere." The methods by which governors secured appointments may be judged by a statement in a report submitted to the Board in I7I5: "Governments have been sometimes given as a reward for services 


\section{IO THE BROAD STONE OF EMPIRE}

done to the Crown, and with design that such persons should thereby make their fortunes. But they are generally obtained by the favour of great men to some of their dependants or relations, and they have been sometimes given to persons who were obliged to divide the profits of them with those by whose means they were procured, the qualifications of such persons being seldom considered." In the spirit of this system the Duke of Newcastle, a great dispenser of public offices, exercised a generous activity. And in the same spirit, one John Lloyd wrote to the Secretary of State, Charles Townshend, that he had resided nine years in South Carolina (whither he came because of ill fortune in the stocks), and he asked for the office of lieutenantgovernor without salary, or first of the King's Council, saying that "what he proposes by it is a little power and perhaps a little profit." The New England school of modern historians declare that the class of men sent out under this system were "generally unworthy men," relations of court favourites, men of desperate fortunes, mere adventurers, and, as such, were largely responsible for the loss of the colonies.

It has been declared that, at a later period, "The early rulers of New South Wales were a series of ignorant and absurd governors, and when the military stage of governorship had merged in the court stage, questionable individuals brought the office into disrepute." Presumably the representatives of the Sovereign have in every period reflected the image of the court; and certainly the colonies were never more fortunate than when the representatives 
of the Sovereign best reflected the image of the court of the Victorian era. But even in the Victorian era it was not always possible to find men of qualifications appropriate to the wide range of duties of a colonial governor. Not a great many years ago a colonial governor, still living, complained to an Under Secretary of the "rubbish" sent out for departmental service in the Crown colonies. "It is true," was the exasperated reply, "that we send out a great deal of 'rubbish,' but it is mostly in the form of governors."

It was undoubtedly true, and not wholly or mainly because of the spirit that dominated the Georgian era. It would be absurd to suppose that social considerations have ceased to influence the appointment of governors, but the evolution of the professional governor with a vested interest in his office has given rise to a new order of difficulties. The instability of the governor's tenure of office, and his position when it terminated, have always been a subject of observation. In a Historical Review of the Constitution and Government of Pennsylvania, published in 1759, there occurs an interesting passage: "There is no Man, long or much conversant in this overgrown city (London) who hath not often found himself in Company with the Shades of departed Governors, doomed to wander out the Residue of their Lives, full of the agonizing Remembrance of their passed Eminence, and the severe sensation of present Neglect." Mr. Collier, in the article referred to above, pointed out that the Colonial Governor, the representative of the Sovereign, reflects all the vicissitudes of kingship. 


\section{I2 THE BROAD STONE OF EMPIRE}

"As monarchs have died prematurely, been assassinated, have fallen in battle, taken their own lives, abdicated, been imprisoned, deposed, banished, restored, tried, beheaded, so colonial governors have died in office, been assassinated, have fallen in battle, laid violent hands on themselves, resigned, been imprisoned, deposed, expelled, restored, impeached, tried, recalled and hanged, and in both sets of cases for similar reasons." On a review of the rise, greatness, and decline of British governors generally, he comes to the conclusion that while a few have been raised to the peerage or advanced in it, while a very few sleep in St. Paul's Cathedral, they usually come home to live in obscurity and die in neglect.

The question of the fate of retired governors has often been raised. In July, I907, Lord Curzon of Kedleston addressed a letter to the press in which he discussed the matter at some length. After suggesting that the Colonial Office might have been saved from unhappy misunderstandings and blunders if an advisory body had been available analogous to the India Council, he pointed out that there is within a three-mile radius of Whitehall a reserve of knowledge, ability and experience in Imperial and administrative problems unequalled in any other country. "As it is, a retired governor who desires to continue to serve his country is driven to become a party politician, and to stand for the House of Commons-a sphere in which he seldom excels. The great residue struggle for places on commercial boards, or read occasional lectures to learned bodies, or rust in rural inactivity." 
I may point out that the Governor's Pension Act, I 865, was passed expressly to prevent the struggle for places on commercial boards, and the association of governors with Companies requisitioning capital for investment or possibly speculative manœuvres in colonies in which they have held appointments.

In a Circular Despatch dated February 1 5, 1907 , Lord Elgin expressed an opinion adverse to the association of ex-governors with such Companies as promoters or directors. He wrote,

"I have the honour to inform you that during the past Session, questions have been put in the House of Commons with regard to certain cases in which ex-Governors of Colonies have taken a prominent part in the organisation or direction of Companies formed to operate in territories which they were recently administering. The publicity which has thus been given to these cases and the public comments which have been made upon them make it desirable that I shouid, without suggesting any impropriety in the action of those concerned, express my personal opinion with regard to such commercial ventures.

"I have every reason to believe that the strongest motive which actuates a former Governor in engaging in a commercial enterprise in a Colony with which he has been connected is that he feels assured, from his intimate knowledge of the whole circumstances, that there are opportunities for development which will benefit the Colony, and that it is incumbent on him not to refuse to give the enterprise the support which his name and reputation must carry with it. A secondary motive, perfectly 


\section{$2 I 4$ THE BROAD STONE OF EMPIRE}

legitimate and honourable, may be that the enterprise may prove successful and co-operation in it remunerative.

"At the same time, I cannot help feeling that retired Governors would be well advised in most cases to refrain from taking a prominent part in the management of Companies which are formed to develop for profit the natural resources of the territories which they have administered. I shall always be ready and anxious to defend the conduct of those who have given years of arduous and devoted work to the Empire; but the strongest and best-merited defence cannot always remove a false impression made by reflections cast on them; and I think myself, therefore, entitled, in the interests of the State and of the Colonial Service, to draw the attention of Officers Administering the Government of Colonies or Protectorates to the necessity for earnest consideration before taking part in any commercial undertaking of such a character."

I believe that Colonial opinion generally would approve a Regulation to the effect that no exgovernors associated with such enterprises should be employed by the Colonial Office in any official advisory capacity.

The recognition of the professional governor as a permanent member of the Imperial Civil Service has materially modified his position. It has practically assured him in the tenure of his office quamdiu bene se gesserit, with a tacit acknowledgment of his claim to promotion when his term of 
office expires or a vacancy occurs. To use a homely expression of the present day, appointments, since the passing of the Pension Act of 1865 , have been modified by the legitimate desire to avoid throwing the professional governor on the scrap-heap. A result of this was, and still is, that appointments have to be found, generally by way of promotion, for governors of proved inefficiency, to keep them in office until they have earned a pension. An analogous difficulty arises from a different cause. Some years ago, when Sir Hercules Robinson returned to South Africa in circumstances extremely distasteful to him, a friend observed to him: "You are at least fortunate in this, that, whatever the Government might do with a governor of less exceptional services, they cannot throw you over." His prompt reply was: "I am astonished at your ignorance of the Government's ways; the only thing that is certain is that they will throw over any governor to save themselves five minutes' trouble in answering a question in Parliament." If there have been instances that have seemed to give some foundation of truth to this observation, it must be remembered that the duty of the Imperial Government to support a colonial governor is subject to constitutional limitations. On July i 4 th, 1850 , Lord Elgin, when Governor-General of Canada, addressed a letter to Earl Grey which has an important bearing on this matter:

"How is the tendency to bring the Imperial and Local Parliaments into antagonism, a tendency so dangerous to the permanence of our system, to be counteracted? By one expedient as it appears to 
me only; namely, by the Governor acting with some assumption of responsibility, so that the shafts of the enemy, which are intended for the Imperial Government, may fall on him. If a line of demarcation between the questions with which the Local Parliaments can deal and those which are reserved for the Imperial authority could be drawn, (as was recommended last session by the Radicals), it might be different; but as it is, I see nothing for it but that the Governor should be responsible for the share which the Imperial Government may have in the policy carried out in the responsible-government colonies, with the liability to be recalled and disavowed whenever the Imperial authorities think it expedient to repudiate such policy."

In such cases, again, compensation may have to be found by transfer to another government, and in this way a small group of governors may occupy the narrow circle of the profession for many years. The consequences are often grotesque. When a vacancy in a government of the highest rank and emolument occurs, there are three classes of claimants. There is the senior man of long and approved service; that may be a paramount claim in any department of the Home Civil Service, but he may have owed his present appointment to some special qualifications for service in that particular colony, while for the vacant appointment he may have no qualification at all, so exceptionally varied are the circumstances of our colonies. Then there is the governor with social influence; what the French call le fils de papa. He has accepted an appointment of inferior emolument or in an unhealthy 
climate, and has hardly assumed the administration before bringing all the pressure he can command to bear on the Colonial Office, to secure his transfer to a governorship better paid or in a healthier climate. After a very short time his wish is granted, and a successor appointed by whom the same process is gone through, till within five or six years the unlucky colony may have had a succession of three or four governors. The third class of claimant is a mysterious person known as "the man in the background." $\mathrm{He}$ is not a claimant for the particular appointment vacant, but has an influence on the selection to be made of which the general public have no conception. He has social or political claims, not essentially different from those submitted to the Board of Trade in the old days I have described. In order to provide for him the vacant appointment has to be given to some fortunate governor holding an appointment that requires little or no administrative experience, or perhaps in an unhealthy climate. Then the "man in the background" is provided for, and if he is le fils de papa his rapid promotion is secured.

Whatever may have been the wisdom, or indiscretion, with which the power of appointing a colonial governor has been exercised, his position remains the same; and in order to understand something of the government of the Crown colonies, it is well to realise it.

Every governor holds office during the pleasure of the sovereign, but the usual term is six years. The general practice is to create the office of governor in each colony by Letters Patent, and then to make each 


\section{I8 THE BROAD STONE OF EMPIRE}

appointment to the office by Commission under the Royal Sign Manual, under which also Instructions are issued to the governor. The Commission is countersigned by a Secretary of State; the Instructions are issued under the Royal Sign Manual with the "signet" attached by the Secretary of State, but without his counter signature; subsequent additional Instructions are given to the governor through the Secretary of State. The Letters Patent, Commission, and Instructions are commonly referred to as the Governor's Commission. Permanent instructions common to all governors, are contained in a body of rules known as the Colonial Office Regulations, published annually in the Colonial Office List. In these Regulations the governor is stated to be the "single and supreme authority responsible to, and representative of, His Majesty." His Commission entitles him to the obedience, aid, and assistance of all military and civil officers; but he is not therefore invested with the command of any part of the British regular forces in the colony.

As regards the army,the immediate direction of any military operations. If military operations are necessary, the officer commanding the troops assumes the entire military authority; but it is for the governor to determine the objects with which, and the extent to which, the King's troops are to be employed, and to give directions as to their distribution and employment. As to the matters within each other's province, the governor and the officer commanding are bound to consult each other.

As regards the navy, - the governor has no 
authority over the movements of His Majesty's ships and is not entitled to issue orders to their officers; but it being a general obligation on all His Majesty's civil and military officers to afford mutual assistance in all matters pertaining to the King's Service, naval officers are instructed by the King's Regulations to pay due regard to such requisitions as they may receive from the governor, having for their object the protection of His Majesty's possessions, the benefit of the trade of his subjects, or the general good of his service. In urgent cases where a requisition from the governor may conflict with the instructions of his naval superior, a naval officer is to decide on his judgment, bearing in mind "the grave responsibility that would rest on him, if the circumstances were not such as to fully warrant the postponement of the instructions from his naval superior to the more pressing requisition from the Governor." In another chapter I shall illustrate the practice of these instructions in the case of a governor deciding to send troops from his command to other parts of the Empire in a state of war.

As regards the civil administration, the limits of the governor's powers are very different in selfgoverning and Crown colonies. In the former, the position of the governor is that of a constitutional sovereign acting through his advisers or ministers, interfering with their executive and legislative powers only as a friend or counsellor. In the latter, the governor is not in the position of a constitutional sovereign; he is actual ruler. $\mathrm{He}$, and he alone, is responsible for the conduct of 


\section{THE BROAD STONE OF EMPIRE}

the local affairs of the colony. He is responsible to the Home Government, while his advisers are responsible to him, and not, as in a self-governing colony, to the local legislature.

The Governor's Commission contains express provisions as to his executive, legislative, and judicial powers and duties. $\mathrm{He}$ is the executive head of every department of the administration with power, subject to limitations to which I shall refer, to appoint, suspend, or displace the titular head. $\mathrm{He}$ has the power to initiate, control, and veto legislation. In judicial matters the Crown's prerogative of pardon is delegated to him. The miscellaneous provisions of his commission instruct him to promote religion and education.

Apart from the powers expressly and implicitly given, the governor's commission, "in a characteristically English way," as Sir Henry Jenkyns put it, "by authorising the Governor to do and execute all things that belong to the office, incorporates the practice without stating it." 1 The exercise of this "reserve power" has given rise to controversy, as in the case of Governor Eyre's proceedings in Jamaica; but there can be no doubt that a governor will always be held to have the power necessary to meet any emergency that may arise and take immediate action for the safety of the colony.

But if the governor of a Crown colony has technically much more absolute authority than the governor of a self-governing colony, he is constantly reminded that he is under the control of the

${ }^{1}$ British Rule and Jurisdiction beyond the Seas (London, 1902). 
Colonial Office. In his executive capacity he finds that, except in the appointment of the humblest officers, his recommendations can be set aside, his legislation vetoed or modified by instructions to amend, his annual budget dislocated, even his exercise of the clemency of the Crown adversely criticised.

When I first received an appointment in the Colonial Service from the Duke of Buckingham, he said to me, "You will find it very difficult to satisfy both the Government and the colony." That is the governor's position in a nutshell. He has to satisfy the Colonial Office and the colony. Obviously there are interests of the Empire to which the interests of its constituent parts must be subordinated, and so far as my experience goes, the Crown colonies are willing, are indeed proud to make concessions to imperial interests. It was interference with purely local concerns that caused the secession of the North American colonies; it exasperates the demand for self-government, and introduces a needless element of irritation in the relations of the Crown colonies with the Colonial Office. And the cause of this interference is to be found in the constitution of the Colonial Office, which places the control of the governor, who is the experienced representative of the colony's requirements and wishes, I will even add partialities and prejudices, in the hands of men who, whatever may be their intelligence and ability, are absolutely ignorant of these things.

The matter seems to me of so much importance that I give place to the views of Sir Augustus 


\section{THE BROAD STONE OF EMPIRE}

Hemming, who could speak with an experience of over forty years.

"Another matter which, to my mind, has always been a source of weakness to the Colonial Office, and has led to many mistakes, is the lack of personal knowledge of the colonies, and of their local circumstances, conditions, and requirements, which exists, and always has existed, among the members of the staff. In my earlier days I do not remember a single man in the Office who had ever visited a colony, or knew anything about the people he was assisting to govern. It appeared to be thought almost undesirable that any such knowledge should be acquired. I remember, in my own case, that when I was at the head of the West African Department, the then Governor of the Gold Coast (the late Sir W. Brandford Griffith) invited me to go out there during the winter months and study the conditions on the spot. I expressed my willingness to do so if allowed, but when the request for permission was preferred to the then Under Secretary of State, it was refused on the ground that there appeared to be no necessity for the visit. No doubt it was not absolutely necessary that I should go, but I venture to think the experience I should have gained would have been of great use and advantage in the performance of my work, and would have made the advice or information which, in my position, I might be called upon to give, on matters connected with the colony, more valuable and practical.

"In later years, and especially during the time $\mathrm{Mr}$. Chamberlain was Secretary of State, this defect has been to some extent improved, but even now the 
number of clerks, or even of higher officials, who have any colonial knowledge or experience is very limited.

"Moreover, the best use is certainly not made of those clerks who have visited any of the colonies, or have been employed there officially. It might reasonably be supposed that on their return every endeavour would be made to attach these clerks to the particular department which supervised the affairs of the colony in which they had been. On the contrary, the practice appears to be to place them in some department where the knowledge and experience they have gained will be of little use. For example, a man who has held an appointment in the West Indies will be sent to the South African department, and vice vers $\hat{a}$. The reasons for this anomalous treatment are not easily comprehensible."

To this I will only add that the presence of these clerks in the Office, if employed as Sir Augustus Hemming suggests, without an advisory Council, will prove an even more serious peril, if it should lead to the control of governors by officials who have been their own subordinates, permanently transferred to the Colonial Office, and gradually losing touch with the constantly changing circumstances of a colony in which they have for a time resided.

I have already given reasons for urging the creation of an advisory Council at the Colonial Office. It would remove this source of weakness, and thus could hardly fail to bring the governor into easier relations with the Office. I believe it would at the same time bring him into easier relations with the colony. 


\section{THE BROAD STONE OF EMPIRE}

For at present the difficulties of the governor are great. They will be better understood after a study of the types of legislature established in different Crown colonies. But it may be said generally that in all colonies not having responsible government, and especially in colonies having representative institutions without responsible government, the only possible method of government is by suasion. Government by suasion is no doubt the most diffcult of all administrative arts. I will close this chapter with a brief consideration of the principles which alone can guide it to success.

A governor should have no motive but the good of his colony, and the conviction that his own reputation is inseparably connected with it. In order to form a right appreciation of what the good of his colony really is, he must keep himself in constant contact with the best representatives of the different elements it contains,--European, African, or Asiatic. $\mathrm{He}$ should, so far as possible, study their present characteristics in relation to their history, religions, and traditions, and endeavour to make them feel that he has no object but their protection in a spirit of equal sympathy with all, without partiality or prejudice.

Every legislative measure he proposes should be based on his adequate appreciation of what is for the good of the colony, modified by what he conceives to be the interest of the Empire. If the Secretary of State opposes it, he must urge the case on behalf of the colony to the best of his ability; but when a question is once decided, discussion must give way to co-operation. It is useless, 
however, to suppose that he can effectually cooperate with the Secretary of State without securing the co-operation of the representatives of the colony; and, so far as my experience goes, there is but one way to secure it. He must take the entire responsibility of the measure as a suggestion of his own which he has no desire to press or enforce, but which he would be glad to support if brought forward by a representative in the Council of Government. Sir Mountstuart Grant Duff, in his Notes from a Diary, records the saying of an old English Jesuit: "It is surprising how much good a man may do in the world if he allows others to take the credit of it." Mr. Bernard Holland, commenting on this, observes that a viceroy, who is to all intents and purposes a constitutional monarch, holds a singularly good position for influencing in this unseen way the course of the world's history. I believe there can be no better rule of conduct for the guidance of a colonial governor. I am certain that I have never departed from it without regretting it. 


\section{CHAPTER VIII}

\section{LOCAL, GOVERNMENT}

The Colonial Office List classifies our colonies into two groups.

I. The Colonies possessing responsible government, in which the Crown has only reserved the power of disallowing legislation, and the Secretary of State for the Colonies has no control over any public officer except the governor. In all matters affecting the internal affairs of such a Colony the governor acts on the advice of ministers who are responsible to the legislature.

II. Colonies not possessing responsible government, in which the administration is carried on by public officers under the control of the Secretary of State for the Colonies (commonly known as Crown Colonies), and Protectorates similarly controlled.

These Colonies are constitutionally grouped as follows.

(i) Colonies possessing an elected House of Assembly and a nominated Legislative Council:

Bahamas, Barbados, Bermuda.

(ii) Colonies possessing a partly elected Legis- 
lative Council, the constitution of which does not provide for an official majority :

British Guiana, the Island of Cyprus.

(iii) Colonies possessing a partly elected Legislative Council, the constitution of which provides for an official majority:

Fiji, Leeward Islands, Mauritius. Jamaica, Malta,

(iv) Colonies and Protectorates possessing a Legislative Council nominated by the Crown :

British Honduras,

Ceylon,

East Africa Protectorate,

Falkland Islands,

Gambia,

Gold Coast,

Grenada,

Hong-Kong,
Nyasaland,

St. Lucia,

St. Vincent,

Seychelles,

Sierra Leone,

Southern Nigeria,

Straits Settlements,

Trinidad.

In all the above Councils, except British Honduras, the constitution provides for an official majority.

The Legislative Councils of Gambia, Sierra Leone, and Southern Nigeria have power to legislate for the following Protectorates respectively:

Gambia, Sierra Leone, Southern Nigeria.

(v) Colonies and Protectorates without a Legis lative Council :

Ashanti,

Basutoland,

Bechuanaland Protectorate,

Northern Nigeria,

Northern Territories of the

Gold Coast,
St. Helena,

Uganda,

Islands included under the Western Pacific High Commission. 
In all Crown Colonies and Protectorates, except Bahamas, Barbados, Bermuda, British Honduras, and the Leeward Islands, the Crown has the power of legislating by Order in Council.

On this classification I have only to observe that the colonies of Bahamas, Barbados, and Bermudas represent, though not in every case without solution of continuity, the earliest type of colonial governments, but they lack the essential element of responsible government, the control of the executive by the legislature.

The Constitution of British Guiana is unique. It consists of an Executive Council, a Court of Policy, and a Combined Court. The Executive Council consists of the governor, ex-officio and nominated members. The Court of Policy is composed of the governor, seven official members and eight elected members; its functions are legislative only. The Combined Court consists of the governor and the Court of Policy, combined with six members elected as financial representatives; it has the power of imposing the taxes, auditing the public accounts, and discussing freely and without reserve the items on the annual estimates prepared by the governor in Executive Council. The distinctive character of the Constitution lies in the separation of the legislative from the taxing powers. The casting vote of the governor maintains an official majority in legislation; the elective element has a large majority in taxation.

Let me here very briefly state what I believe to be the essential elements necessary for the stability of responsible government. The fact that all our 
colonies having such a government are in the temperate zones is not accidental. It has now come to be generally accepted that the elements necessary for the stable conduct of responsible government in our colonies and dependencies are wanting in the tropics, and cannot be supplied by any conceivable political agency. The justification of responsible government in a colony rests on the ability of the inhabitants of European descent to form a permanently settled homogeneous community in a climate favourable to their development in the same physical, ethical, and political conditions that have produced the European. These conditions can only be found in temperate climates. In the tropics physiological and other causes, acting through long ages, have produced races able to stand the fatigue of strenuous manual labour which it is impossible for the white man to endure; nor can the descendants of Europeans be rendered capable of such labours by any period of residence or process of acclimatisation. The racial distinctions thus created are inconsistent with the ethical principle of social equality which underlies responsible government. The absence in the tropics of the conditions essentially necessary arrested the extension of responsible government to the Crown colonies, with a view to their ultimate separation, and led to several of the West Indian colonies voluntarily surrendering Constitutions they had been allowed to retain after the secession of the North American colonies, and substituting new ones.

In the study of a Constitution appropriate to the local environment of the West Indian colonies with 


\section{THE BROAD STONE OF EMPIRE}

distinctions of race, circumstances, and degrees of civilisation, the Imperial Government had the experience of a wide range of systems. The system of a single legislative chamber had existed in Ceylon since 1831 , modified by the progressive development of a desire to give the heterogeneous groups of the community a fair share of representation, but consistently controlled by the principle that the power of the Crown in the legislature must avail to overcome every resistance that could be made to it. The Act of 1842 , setting up in New South Wales a council with one-third of its members nominated by the Crown, and two-thirds elected by constituencies, marked a distinct line of cleavage between the policy that was to control the constitutions of the self-governing and Crown colonies respectively. From that date, there is hardly a constituent part of the Empire, except Ceylon, which has not been made the subject, I had almost written the corpus vile, of constitutional experiments by Orders-inCouncil, local Ordinances, and Imperial Acts. The confusion that has followed may be studied in the History of British Rule and Jurisdiction beyond the Seas, by Sir Henry Jenkyns, and other technical literature; but throughout the confusion there can always be traced a line of bifurcation between the self-governing and the Crown colonies, following the natural cleavage of the temperate and tropical zones.

In 1865, accordingly, the Imperial Government had ample opportunity to study constitutional experiments with the usual three courses open to them: to adhere to the Ceylon type of Crown 
colony; or to adopt the single chamber type of the Australian colonies; or to construct a new type out of the other two. They were debarred from the Australian type by the motive which had induced the West Indian colonies to surrender their constitutions and the Government to accept the surrender. This was declared on both sides to be to confer on the Crown the ultimate power of control over the colonial legislatures in their internal affairs. The Government therefore decided on the Ceylon type, modified by a principle of the Australian type. In order to understand this, a brief account of the Ceylon type is necessary.

The Legislative Council of Ceylon includes in a single Chamber three elements; members of the Executive Council by virtue of office; certain Heads of Departments nominated by the Crown as administrative experts, for instance Heads of the Customs, Survey, and Public Works Departments ; and members nominated by the Crown as representatives of groups of communities as Europeans, Singhalese, Tamils, and Burghers, or of groups of interests, such as agriculture and commerce. The members of the Executive Council are bound to support government measures, under the same obligations as ministers in England or in the self-governing colonies, with the serious alternative of having to resign their official career. The nominated Heads of Departments have a larger liberty, but may be called on to support the government or to resign their seats as members of Council, but not necessarily their departmental office. The members nominated to represent communities or groups of 


\section{THE BROAD STONE OF EMPIRE}

interests are wholly independent of the Crown as regards their personal fortunes, and are free to exercise their votes on behalf of the interests they represent. As, however, the official element of the Council is always in a majority, it represents a type of legislature in which the ultimate control of the Crown is supreme, and responsibility is never divorced from power.

It will be seen that in the Council of Government of Ceylon there is no elective element, in the sense in which the term is usually understood; but it has grown to be the usage that the governor, in recommending members for the approval of the Crown, should consult the recognised leaders of the communities concerned, and in case of interests, recognised representative bodies, such as the Chambers of Agriculture and Commerce.

I am glad of an opportunity to express my opinion, founded at least on long and varied experience of constitutional experiments in tropical colonies, that the Ceylon type of Constitution, wisely administered as it has been, secures for the native community a more effective representation of its interests than could be obtained by any electoral method the ingenuity of the Empire has hitherto devised. Under the present system the native communities are represented by men of the highest intelligence, and enjoy an hereditary influence, the growth of ages. In my belief the election of representatives by any system based on a pecuniary qualification is totally opposed to the ethical traditions of the native races, and would only result in substituting for those who are perfectly qualified advisers of the government, a 
class of men who would owe their position to electoral agencies in no way representative of those national characteristics to which it is our desire to give due weight and consideration. Moreover, I believe that representation by groups of interests is a system infinitely more appropriate to the circumstances of Ceylon than any conceivable system of representation by members elected by territorial constituencies without regard to diversity of interest. And I go further; I desire to make a most emphatic declaration that, in my opinion, the grant of representative institutions or responsible government to Crown colonies is not really a grant of larger and fuller representation to the mass of the community. It is, on the contrary, a restriction of that representation; because under the Crown colony system of an official majority, the official majority is the representative of the liberties of that enormous majority of the people whose interests have never been represented by any electoral system hitherto invented.

I am not, however, surprised that the policy of developing the electoral system in the government of the East, as illustrated in the reform of the Indian Councils, has led to the appointment of a Commission to consider the introduction of an elective element into the Legislative Council of Ceylon. I venture to express a hope that any reform that may be adopted will maintain the principles of nomination, representation by groups, and an official majority.

To revert to the decision of the Imperial Government, when called on to construct a new legislative system for the West Indian colonies which had by their own deliberate act surrendered their Constitu- 


\section{THE BROAD STONE OF EMPIRE}

tions. The decision arrived at was in brief to adopt a system based on the Ceylon type, but modified by the elective principle of the Australian type.

After some experiments, it was in 1868 , a year that in many respects marked an epoch in the colonial policy of the Empire, that the lines of a new legislative system for the West Indies were definitely laid down in a despatch by the Duke of Buckingham. Seldom, if ever, has a system been more clearly explained, and in all essential principles it may be said to constitute the fundamental law of Crown colony government to the present day. As outside Crown colony legislatures its existence is scarcely known, it may be conveniently reproduced at a time when questions of race and privilege in the tropics are recognised to be of the first importance.

COLONIAL OFFICE CIRCULAR.

Downing Street,

I 7 August, I 868.

Sir,

Questions having arisen in one or another of the West Indian Islands as to the relations between the Government and the Members, Official, Nominated, or Elected, of the recently constituted Legislatures, it may be convenient that I should review the position of Her Majesty's Government in reference to those Legislatures, and explain to you the sentiments they entertain upon the subject.

It may be well that I should advert, in the first place, to the objects with which it may be presumed that the old Legislatures were led, voluntarily and 
without any suggestion from Her Majesty's Government, to constitute the new ones.

Until the year 1865 , when, in the Island of Dominica, the first steps were taken to construct a new Legislative Body in substitution for the one then existing, the powers of legislation for each of the Leeward Island Colonies were virtually exercised by Assemblies elected by a very limited number of the Colonists, and the only control over their legislation was the negative control by the veto of the Crown or by the action of a Legislative Council, the Members of which held their seats for life. The Population at large, consisting of uneducated Negroes, neither had nor could have any political powers; they were incapable of contributing to the formation of any intelligent public opinion; and the consequence was that the Assemblies performed their office of legislation under no real or effective responsibility.

They became aware apparently that irresponsible legislation by small local Bodies was not for the interest even of the Members of those Bodies themselves, or of the class which they represented, and still less of the inhabitants at large; and when the example of Jamaica in 1866 followed upon that of Dominica in 1865 , one after another of the Leeward Island Legislatures reconstructed themselves in like manner, though not upon one identical model, and lastly, amongst the Windward Islands, St. Vincent's was led to take the same course.

The new Legislatures, whilst more or less differing from each other in their component parts, have one feature in common,- that the power of the 
Crown in the Legislature, if pressed to its extreme limit, would avail to overcome every resistance that could be made to it. The reasons for vesting this ultimate power in the Crown were well understood, both by Her Majesty's Government and by the Assemblies.

If the Assemblies did not desire to retain power for its own sake, neither certainly did the Crown desire to assume it for its own sake. The object of all parties was to establish a system of Government and Legislation by which the financial condition of the Colonies should be improved and their agricultural and commercial interests be promoted, by which industry might be encouraged, crime repressed, and the welfare of all Classes be better provided for. For these ends Her Majesty's Government were willing to accept the trust which the Assemblies were desirous to place mainly in their hands. But Her Majesty's Government were not willing to accept this trust unless accompanied by such a measure of power and authority as would enable them to perform effectively the duties which it was expected of them to undertake. And the views thus entertained by Her Majesty's Government were distinctly announced. They considered that where there is no wide basis for constituent and representative power and responsibility to rest upon, there is no eligible alternative but to vest power and responsibility substantially in the Crown; and whilst they did not object to a Legislature partly nominated and partly elective, they declared themselves unable to approve a Legislature in which, though some of the Members might be nominated, a small number 
of elective Members should have a majority of votes. In a Legislature so constituted the powers of legislation would be virtually in the hands of a very few irresponsible Colonists.

In the constitution of all the new Legislatures, though each differs in some particulars from the others, the requirements of Her Majesty's Government have been substantially satisfied.

[The despatch details the Legislatures, and shows that in each the Crown has reserved a casting vote.]

Such being the composition of the several Legislatures, it is further to be observed that in all of them the Nominees can be changed at the pleasure of the Crown, either individually or by dissolutions.

The result is that there are, or may be, in one or another of the Legislatures six varieties of relation between members of the Legislature and the Crown.

I will explain to you the view taken by Her Majesty's Government of each of these relations:

Ist. There is the Governor or Lieutenant-Governor himself, who is bound of course to obey the Queen's commands conveyed to him by the Secretary of State in his legislative as well as in his executive capacity, whether or not the course prescribed accord with his personal views and opinions.

2nd. There are the Members who hold their seats in virtue of offices held under the Crown, and who cannot therefore be displaced otherwise than by depriving them of their offices. These Officers being part and lot of the Executive Government, are subject to obligations similar to those of the 


\section{THE BROAD STONE OF EMPIRE}

Governor or Lieutenant-Governor, and they may, IF NECESSARY, be required to support the Crown in the Legislature according to such directions as may be given to them by the Governor or LieutenantGovernor as the Representative of the Crown. But it is not considered expedient by Her Majesty's Government that without necessity the same implicit obedience should be exacted from Officers of the Crown in their legislative capacity as would be due from them in the execution of their offices. Legislation includes within its range questions of religion and other questions of high moral import, in respect of which Officers of the Crown may happen to have conscientious scruples, and if after explaining their difficulties to the Governor he should be unable to remove them, they may reasonably expect to be excused from taking part in measures to which they object on these grounds. At the same time an Officer whose seat in the Legislature is by Law inseparable from his office, could not be continued in the office and the seat if his conscience should not permit him to give the Crown such a measure of support as may be necessary to enable the Governor to carry on the business of Government in the Legislature on the principles and according to the intention with which the Legislature was constituted. It is very rarely, if at all, that such a case can be expected to arise.

3 rd. There is the Nominee Member of the Legislature, who, though not taking his seat in virtue of his office, happens to be a salaried servant of the Crown. It would be highly inexpedient that a public servant who is bound to act in subordination 
to the Governor in a paid office, should not give a general and effective support to the Governor's measures in the Legislature. If not disposed to do so, or if on any special occasion on which the Governor has strong and cogent reasons for requiring his support, he sees fit to refuse it, he may be allowed to retire from the Legislature, but the Governor would be entitled to object to his continuing to retain both his office and his seat.

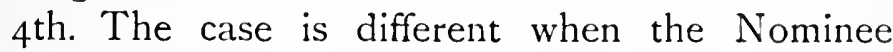
Member of the Legislature does not hold any office of emolument under the Crown. He will, indeed, naturally understand that holding his seat by nomination of the Crown, he has been selected for it in the expectation and in the confidence that he will co-operate with the Crown in its general policy, and not oppose the Crown on any important question without strong and substantial reasons; but of the validity of these reasons he will be himself the judge.

5th. The case of an Elective Member holding salaried office under the Crown differs in degree rather than in principle from that of a Nominated Member holding such an office. He has duties to his constituents as well as to the Crown, and though if he should find himself habitually, or often, or on important questions, unable to reconcile these different duties and to give his support to the Governor in the Legislature, the Governor would be justified in requiring him to resign either his office or his seat, yet it would be incumbent on the Governor to give a liberal consideration to any difficulties in which he may be placed, and not to press for his support in cases in which it is not needed, or in 


\section{THE BROAD STONE OF EMPIRE}

which the expediency of the measures in question may be open to fair and reasonable doubt.

6th. The last case is that of the Elective Member who does not hold office of emolument under the Crown. He, of course, will support or oppose the Government as he sees fit, and it will be his duty to exercise a vigilant supervision over the measures introduced by the Government, lest in any case local official interests, which are no doubt strongly represented in the Legislature, should prevail to the prejudice of public interests; and if in any such case, or in any case which should appear to them to be of this nature, the Elective Members should be outvoted, it would be their duty to enter a protest setting forth the grounds of their objection, and to require of the Governor that he should transmit it for the consideration of the Secretary of State. It is thus that in communities in which, from the absence of constituencies at once large and enlightened, the Representative element in the Legislature must necessarily rest upon a very narrow basis, the responsibility of the Government can still be made effective; for the Secretary of State is responsible to Parliament, and Parliament is not slow to listen to any complaints of alleged misgovernment in the Colonies.

Not only in the case of a protest by the Elective Members, or a majority of them, but also on other occasions on which serious differences of opinion may arise, unless the public interests would suffer materially by delay, it will probably be the best course to refer the question to the Secretary of State. Thus, in any important case in which salaried Officers of 
the Crown elected or nominated to seats in the Legislature desire to withhold their support from Government measures, and the Governor does not think it right to permit it, it will be desirable, unless time is of vital importance, that the Governor should not at once call upon them to relinquish either their office or their seat, but that he should refer the matter for the consideration of Her Majesty's Government.

It only remains for me to observe that, if the constructions which I have placed upon the duties and obligations of the different Members of the new Legislatures shall be frankly and cordially adopted (as I am aware of no reason why they should not), the Legislatures as now constituted may be expected to do much for the well-being and prosperity, and especially for the financial good government, of the Colonies in which they have been established. In the constructions which I have placed upon these duties and obligations I have not aimed at defining them with precision. They are most of them not of a nature to admit of precise definition, and in these, as in all other mixed political bodies, success in cooperation is to be obtained, not by seeking to define what is in its nature indeterminate, but by a disposition on all sides not to press opposing powers to what may be supposed to be their ultimate limits, and to give ample scope and allowance in practice to those elements in the Legislature which have not a legal predominance.

I have, etc.,

(Signed) Buckingham and Chandos. 


\section{THE BROAD STONE OF EMPIRE}

It will be observed that the new system modified the Ceylon system in two particulars. It introduced the elective principle, based on a property or pecuniary qualification, and while insisting that the power of the Crown must, if pressed to its extreme limit, avail to overcome any resistance that could be made to it, reduced the official majority to the casting vote of the governor.

An important modification of this system was introduced when it came to be applied to Jamaica, which had become a Crown colony of the Ceylon type by the voluntary surrender of its ancient Constitution after the rebellion of I 865. In i 88 i a Royal Commission was sent out to inquire into the question of a new Constitution, and this was followed in 1882 by a petition from the colony advocating a Constitution of the Australian type, the Council to consist of twenty-two members, eight nominated and fourteen elected. After two years of controversy on the question of the proportion of official to unofficial members, in the course of which Sir Henry Norman, then Governor of Jamaica, protested against giving the elected members a majority, the Constitution was fixed by Orders in Council. The Legislative Council was composed of the governor and five ex-officio members, and such other persons, not exceeding ten in number, as the Crown may from time to time appoint, or as the governor may from time to time provisionally appoint, and fourteen persons to be elected as provided by the Orders in Council. There is also a Privy Council with the usual powers and functions of an Executive Council. At the same time an Instruction laid down that "it 
is the Governor's duty to override the votes of the elected members, if, in his opinion, the public interest absolutely requires it."

It was natural that while the question of the Jamaica Constitution was agitating the Crown colonies, an agitation in favour of the introduction of the elective system should be started in Mauritius. The case against the proposed change of system was ably argued by the acting Governor, Sir F. Napier Broome, and in June, 1883 , Lord Derby refused to permit the introduction of an elective element into the Council. Before Lord Derby's despatch had reached the colony, Sir F. Napier Broome had been promoted to be Governor of Western Australia, and had been succeeded by Sir John Pope Hennessy. The story of the reform of the Constitution of Mauritius from this point is probably unique in the annals of constitutional reform, and I can narrate it with a probably unique experience.

When, towards the close of the year 1882 , I was appointed Colonial Secretary for Mauritius, I was not aware that Sir John Pope Hennessy had at the same time been appointed Governor of the colony. From public sources of information I knew something of Sir John's adventurous and turbulent career, that he had appeared as an angry boil on more than one part of the body of the Empire; and I came to learn that he had been offered the government of Mauritius only after the responsible ministers of an Australian government to which he had been appointed had refused to receive him. By personal friends and governors who had 


\section{THE BROAD STONE OF EMPIRE}

preceded or succeeded him, and colleagues who had served under him, I was warned that my berth was not likely to be a bed of roses. But I was not dismayed; my experience in Ceylon, where I had recently held the office of Director of Public Instruction, had shown me the Roman Catholic religion as an efficient agent of loyalty, and the appointment of a Roman Catholic governor to Mauritius held out hopes of a policy in which I could co-operate with conscientious sincerity. I had reason to believe also that I should find myself in agreement with Sir John on the general principle of questions affecting the relations of Europeans to communities of African and Asiatic descent. During a short tenure of office as Administrator of the Government prior to Sir John's arrival, I drew up a memorandum on the educational system of the colony, based on the principle I have explained in this work, and I availed myself of opportunities that occurred to recognise an equality of right to promotion between Mauritian and British-born members of the Civil Service, both of which questions had been given prominence in the agitation for a reform of the Constitution. Though my tenure of the office of administrator was brief, it secured me the approval of the Colonial Office, and the hearty concurrence of Sir John Pope Hennessy when he took over the government. The relations thus established were confirmed by events consequent on the outbreak of war between France and Madagascar a few weeks later. The occupation of Tamatave, and the refusal of the French Admiral to allow a British steamer to call at that port for 
passengers and mails, were the cause of prompt action by Admiral Sir William Hewitt, Commander in Chief of the East India squadron, stationed at the time in Mauritius with a view to contingencies that might arise from the war. Affairs were complicated by the imprisonment of Mr. Shaw, a Protestant missionary, and thus a situation was created which required some care. In the negotiations that followed, the Governor was good enough, as he afterwards generously reported to the Colonial Office, to allow me a free hand. They resulted in maintaining friendly relations with the French Admiral, and allaying the irritation of the missionaries. This drew us more closely together. Meantime, my social relations with Sir John and his family were of the happiest, and I may say here, once for all, that they were never severed. Many years later, his son and mine were associated in a campaign in Africa in circumstances that leave an undying memory. Among those who, like myself, were frequent guests and constant advisers of the Governor were the Admiral, Sir William Hewitt, Mr. (afterwards Sir) Célicourt Antelme, a Member of the Legislative Council, a representative of the Catholic community of Mauritius of French descent who find it possible to combine attachment to the traditions of old France with loyalty to the British Government, and the Roman Catholic Bishop of Port Louis, Bishop Scarisbrick. These influences, working in perfect harmony, seemed likely to produce in the European community of Mauritius a little Canada. Never, in the history of any British colony acquired by cession from France, has there 


\section{THE BROAD STONE OF EMPIRE}

been an opportunity of brighter promise. But it was not for long. It soon began to be felt that Sir John Pope Hennessy was not concerned to produce a little Canada but a little Ireland, and that he designed to use the Roman Catholic Church as an instrument to effect his purpose. Within a few months Sir John's policy, concentrated in the formula "Mauritius for the Mauritians," had alienated the Admiral. The Admiral was quickly joined by the officer commanding the troops, and there followed a breach of all social relations between the Governor and the naval and military authorities. The causes and ultimate results of this discontent will be dealt with in another chapter; it naturally grew in importance as it extended its influence over the whole civil community of British origin, while the formula "Mauritius for the Mauritians" quickly revived racial prejudices that had been lately slumbering. It was capable of interpretation, and was generally interpreted by the community of Mauritian birth or descent, in a sense perfectly consistent with loyalty to the Throne and the integrity of the Empire. It was only when the policy expressed by the formula came to be worked out in a definite scheme for the reform of the legislature that its significance, as interpreted by the Governor, was made clear. Within six months two of the Governor's original advisers and counsellors had seceded; only Bishop Scarisbrick and myself remained. Duty and inclination alike prompted us to support the Governor's policy, interpreting it always privately and publicly as a policy designed to promote a closer attachment between the colony 
and the Empire. Of the sincerity of Bishop Scarisbrick's desire that his Church should be a link of connection, and not a separating force, I never entertained a doubt for a moment. But the fact that the Governor's methods had within six months resulted in a double cleavage, - a racial cleavage and a cleavage between the heads of the civil and military administration-was too serious to be overlooked. It made my position one of constant anxiety, all the more that Sir John never seemed tired of expounding to all and sundry his opinions on the question of Home Rule in Ireland. Benjamin Franklin, before the secession of the American colonies, declared that the easiest way of destroying a great empire, or a great cake, was by cutting slices off the circumference. From Sir John's talk on Home Rule with more or less covert reference to Mauritius, added to what was common knowledge of his official career, I was forced to a suspicion that his policy was to dig a knife into the centre and thus hasten the process of cutting slices off the circumference.

I had at this time completed five years of continuous service in Ceylon and Mauritius without leave of absence except for the period of my voyage between the two colonies. They had been years of strenuous labour, and I decided now to obtain leave and lay the whole state of affairs before the Colonial Office. On my arrival home, I found the Office perfectly informed of what was going on, and every subsequent mail from the colony during my period of leave confirmed the knowledge of the Office, and the justice of my inferences. As the result, I returned 
to Mauritius, instructed by the Permanent Secretary, Sir Robert Herbert, that I was to use every endeavour to continue to hold my office and give the Governor the support it demanded; but that if I found I could not continue to hold it with honour, I was to return.

What happened immediately after my leaving the colony was told by an independent writer, the Hon. J. W. Fortescue, in an article in the National Review in December, $\mathrm{I} 89 \mathrm{I}$.

"In December, r883, six months after Sir John's arrival, the matter was again brought forward, this time in the Council itself. Two resolutions, - the one condemning the then existing Constitution; the other claiming as indispensable a Council of twentyone members, whereof at least two-thirds should be unofficial-were duly moved, talked over at great length, and passed,- - the first by nine votes to six, the second by eight votes to seven. Sir John Pope Hennessy, in reporting the fact to the Colonial Office, strongly supported the reformers, confirming all that had been said by Mr. Broome as to the superiority of the middle class in Mauritius, and adding that the relations between the Indians and their employers, and generally between the higher and the lower classes, were of a trustful and friendly nature unknown to other colonies. Of this trustful friendliness more will be said; but meanwhile it is curious to note the composition of the Council at the time of this most important debate. Of the eight official members, no fewer than five were acting officers, one at least of whom held opinions diametrically opposed to those of the gentleman in whose place 
he sat. Further, the Nestor of the Council [Sir Célicourt Antelme] was too ill to attend, and his vote was consequently lost. On such small things do grave issues hang. Had these two members been present, both resolutions would have been lost."

The reply of Lord Derby to these resolutions was that the Imperial Government would not press its objections to a reform, and would be prepared to allow a certain number of the unofficial members of Council to be elected instead of nominated. He reiterated, however, his opinion that the existing Constitution was adequate to secure a fair and full representation of the wishes and requirements of the colony.

It is unnecessary for me to discuss the controversy that ensued on the questions of an official majority and the qualifications for franchise.

In May, I885, a Council of Government was constituted, consisting of the governor and twentyseven members, eight ex-officio, nine nominated by the Crown, and ten elected, the governor having a casting vote. It was further provided that at least one-third of the nominated members must be persons not holding any public office. In practice, nominated members have included more than one-third of such persons ; but an official majority can at any time be created by dissolution. As regards the franchise, the Imperial Government peremptorily rejected any educational test which should require Indians to read or write in any language but their own. The idea of a colour-bar had never been suggested. Before the new Constitution had been brought into force, I left the colony for reasons which will be elsewhere 


\section{THE BROAD STONE OF EMPIRE}

explained, and I therefore took no part in its work till I returned to Mauritius as Governor in 1897.

I desire, however, to place on record my conviction that the Mauritians associated with Sir John Pope Hennessy in the measures he proposed for the reform of the Constitution were in no way associated with him in his desire to make the question of Home Rule in Mauritius auxiliary to the question of Home Rule in Ireland, and the larger policy of eventual separation.

To more than one it seemed certain that, in the interests of Mauritius, the moment was inopportune for any such association. Events in the Soudan had been followed by the adoption in Ireland of the formula, "England's difficulty is Ireland's opportunity." In a very different sense Canada and the Australian colonies adopted the same formula, declaring that England's difficulty was their opportunity to give material proof of their loyalty.

In Sir Henry Taylor's Autobiography there is an interesting reference to the opportunity. It is contained in a letter written by him in 1865 , in which he declares that "the North American, like the Australian Colonies, and like the Cape, have very naturally renounced all consideration of English interests." While the Autobiography was passing through the press, he was constrained to add this note: "Feb. I885.-In the very week in which this chapter is passing through the press, the Canadian and Australian Colonies have taken steps which are at direct variance with the views I have expressed, whether as to facts or as to forecasts. They have offered to con- 
tribute, at their own cost, contingents of Colonial troops to our forces at war in the Soudan. It was not without reason that I concluded my letter to Mr. Merivale with the acknowledgment that on political questions my opinions are nothing more than conjectures."

I will now proceed to give a brief account of the Constitution of Mauritius in its actual composition, its practical working and its results, during the period of my tenure of the office of governor. The Executive Council consisted of the governor, with five official and two unofficial members nominated from among the elected or nominee members of the Legislative Council. The unofficial members represented the two predominant groups of what is called the general community, the Creoles of pure French and mixed (European and African) descent. The Asiatic community has never been directly represented in the Executive Council; it is effectively represented by the governor and the official members. The Executive Council is an advisory body; the governor is not bound by its decisions, but every member has the right to have his reasoned dissent recorded in the Minutes, and so brought to the notice of the Secretary of State. It is impossible, in my opinion, to exaggerate the value of the unofficial members of the Executive Council in any colony with a Single Chamber Legislative Council of three dimensions. Their most important function is to reconcile the conflicting or diverging interests they respectively represent, and in Mauritius especially to bring them into harmony with the interests of the Asiatic community who constitute 


\section{THE BROAD STONE OF EMPIRE}

the enormous bulk of an uneducated labouring population. But their advice is not less valuable in matters not directly affecting the special interests they represent. They recognise that the Government cannot resign, that ways and means have to be found, and that the local Government cannot divest itself of the power to give effect by legislation to the decisions of the Imperial Government. I may add that in qualifications for their high functions, and in the influence they have exercised in the Council of Government as well as in the general community, there has been nothing to choose between the representatives of the two groups I have indicated.

The Council of Government consisted of the governor and twenty-seven members, eight ex-officio, four official, and five unofficial nominees, and ten elected members, in all twelve official and fifteen unofficial members. The governor's vote and casting vote still left a permanent official minority. An official majority might, if necessary, have been created by a dissolution, and the appointment of six official and three unofficial nominees in accordance with the terms of the Constitution. I am glad to think that it was never necessary to have recourse to this expedient.

At the same time the difficulties inherent in this type of legislature are so important, and have acquired so much additional importance by the introduction of this type of legislature into India, that I may venture to illustrate them.

In the forefront must be placed the question of the adequate representation of the numerical majority 
of the community. In Mauritius a vast majority of the population are of Asiatic origin, and they had no direct representation by election in the Council of Government for two reasons: all but a small minority are excluded from the franchise, not on racial grounds, but because they do not possess the necessary qualification; and the minority were unable to secure the return of a representative by election against candidates belonging to the general community. There remained open the door of entrance into the Council by nomination; but entrance through this door was strongly resisted by a very large section of the general community, on grounds underlying the whole question of the political status of the Asiatic immigrant population. I shall deal with it fully elsewhere. I will only say here that in I90 I I nominated an Indian gentleman of acknowledged position to a seat in the Council, not without opposition, but with the entire approval of the Secretary of State, Mr. Chamberlain, and, I may add, with eventually recognised advantage to the Council.

Apart from the question of the adequate representation of groups of the community, two main difficulties are inherent in the Mauritius type of legislature. They arise out of the necessary and constitutional exclusion of the Council of Government from control over the administrative officers of the Government, and the limitation of the Council's control over the finances of the colony. They are, in fact, problems which since the days of the secession of the North American colonies have found no satisfactory solution except in the 


\section{THE BROAD STONE OF EMPIRE}

grant of responsible government. In colonies, as in India, where the grant of responsible government is admittedly impossible, it must ever remain the highest art of administration to deal with them. The right of interpellation is capable of being used with an ingenuity which brings them in some form or other before the Council at the commencement of nearly every meeting, and too often leaves a sense of dissatisfaction, or even of exasperation, that embitters the whole subsequent proceedings of the day.

In illustration of the difficulties arising out of these questions I will limit myself to instances which resulted in the laying down of fixed principles. The constant interpellations on the subject of the conduct of officials are in the main subsidiary to the general question of the appointment of natives of a colony to the higher offices of trust and emolument. It had been a bone of contention in the many controversies that led to the appointment of Sir Hercules Robinson as a Commissioner to inquire into the administration of Sir John Pope Hennessy, and, in the year I 887, Lord Knutsford, then Sir Henry Holland, in a despatch reinstating Sir John in the office from which he had been suspended, gave an assurance that natives of the island should be, to a very large extent, employed in the principal offices of government. From that time nearly every appointment of an Englishman to high office had been criticised as a violation of this promise, and these criticisms broke into remonstrance when, in I90I, Mr. Bateson, an English barrister of admitted qualifications, alike as regards learning and character, was appointed a stipendiary magi- 
strate, that is, a magistrate appointed to the special duty of hearing cases arising out of the Indian coolie immigration system. The occasion seemed inappropriate for raising the general question of a violation of Lord Knutsford's promise, because the Indian Government had made it a condition of the continuance of the system, that stipendiary magistrates should be independent of local family connections and attachments. It seems idle to expatiate on the propriety of this decision, but the rule had been relaxed, and, without the assent of the Indian Government, a law was passed authorising the governor to give the district magistrates, many of them of Mauritian birth, a commission to act as stipendiary magistrates. However, the unofficial majority of the Council passed a resolution which was in effect a vote of censure on the appointment of $\mathrm{Mr}$. Bateson, and concluded with a hope that Mauritians should as a rule be appointed to act as district and stipendiary magistrates. The discussion on this resolution took a wide range, and if the result of the vote indicated the danger of a permanent official minority, it gave me an opportunity to justify the principle on which the specific appointment at issue was made, and to show by nominal returns how consistently and fully Lord Knutsford's assurance had been acted on. Mr. Chamberlain's reply to my despatch on the subject laid down distinctly the principle on which colonial appointments would be given.

"I have no intention [he wrote] of abandoning the policy of employing a very large number of natives of the Colony in posts for which they are fitted, but I 


\section{$25^{6}$ THE BROAD STONE OF EMPIRE}

wish it to be clearly understood that I can give no undertaking that persons who are not natives of Mauritius will not be appointed to any post in the Colony when after careful consideration I consider that such appointments are necessary or desirable in the interests of the public service. I shall of course always be ready to give full consideration to the claims of local candidates."

This is a principle which I have persistently advocated, and it is essentially in the interest of colonial Civil Servants of colonial birth. In every colony in which a monopoly of government appointments is claimed for qualified natives applications are made by the ablest of such officials for promotion to other colonies. Mauritians have been appointed to high office in other colonies; some have entered the Civil Service of India. A claim to a rigidly exclusive monopoly in the colony of birth certainly does not strengthen a claim to promotion outside of it.

Coincidently with this controversy there arose another of more serious importance in relation to the constitution of single-chamber legislatures without an official majority. It grew out of the limitation of the Council's control over the finances of the colony. Reference has been made to the compromise introduced into the system in Jamaica by Lord Derby in I 885 . In I 899 it broke down. The immediate causes and consequences were admirably dealt with in a despatch addressed by $\mathrm{Mr}$. Chamberlain to the Governor, dated August 2 2nd.

"You are aware that it has been decided in regard to the West Indian question as a whole that 
where financial assistance is given to a Colony by the Imperial Government, the Imperial Government must have control over its finances.

"Arrangements have, as stated above, been made by the Colonial Loans Act, I 899, which will enable the Imperial Government to assist the Government of Jamaica by lending it $£ 350,000$, and if advantage is taken of that assistance and of the promised contribution to the proposed steamer service, I should be bound by pledges given to Parliament to insist on such changes being made in the Legislative Council as would give to the Secretary of State control of the Island finances, but I prefer to treat the question on broader grounds.

"Two plain facts in connection with this matter must force themselves upon the attention of all who study the question, still more of all who are called upon to find a solution to it.

"'The first is, that the 'Home Government,' in Sir David Barbour's words, 'are in the last resort, responsible for the financial condition of Jamaica.'

"The second is, that as a 'working compromise,' the existing system has failed. It is a compromise, but it has not worked. I am not now so much concerned with principle as with practice. As a machine for doing the work which has to be done the present system has failed.

"It is in fact impossible, except where tact and goodwill and friendly feeling exist in an unusual degree, for the government of a country to be carried on when those who are responsible for it are in a permanent minority in the Legislature. I decline to allow the Jamaica Government to remain 


\section{$25^{8}$ THE BROAD STONE OF EMPIRE}

in that position any longer-not merely because it is unfair to them, but also, recognising the ultimate responsibility of Her Majesty's Government for the solvency of the Colony, I must ensure that the measures which they may consider necessary are carried out.

"I must instruct you therefore before the Legislative Council is again summoned, to fill up the full number of nominated members and to retain them, using at your discretion the power given you by the Constitution to declare measures to be of paramount importance. You will give the Council and the public to understand that this step is taken by my express instructions."

In Mauritius the system had not broken down, but it had been found necessary to restrict the limits of control fixed by Letters Patent in 1885 in these terms: "The Council shall not pass, nor shall the Governor assent to, any law, vote, or resolution imposing any tax, or disposing of or charging any part of the public revenue, unless such law, vote, or resolution shall have been proposed by, or by the direction of, or shall have the express approval of the Governor."

The terms of this clause gave rise to frequent discussion and repeated reference to the Secretary of State, and in 1896 were amended to read as follows: "It shall be competent for any Member of the Council to propose any question for debate therein; and such question, if seconded by any other Member, shall be debated and disposed of according to the Standing Rules and Orders: Provided always that no ordinance, vote, resolution, 
or question, the object or effect of which may be to dispose of or charge any part of Our revenue arising within the Colony, shall be proposed, except by the Governor or with his consent."

These terms definitely decided the power of the governor to limit the expenditure of the colony, but this was obviously insufficient to secure a balance in the treasury without the power to maintain an adequate revenue. To maintain this it was necessary to limit the power of an unofficial majority of the Council to repeal taxation. Accordingly, by Letters Patent of August I4th, I90I, the clause was amended as follows: "It shall be competent for any Member of the Council to propose any question for debate therein; and such question, if seconded by any other Member, shall be debated and disposed of according to the Standing Rules and Orders: Provided always that no Ordinance, vote, resolution, or question, the object or effect of which may be to dispose of or charge any part of Our revenue arising within the Colony, or to revoke, alter, or vary any such disposition or charge, shall be proposed, except by the Governor or with his consent: And provided further, that no vote, resolution, or question, the object or effect of which may be to suspend the Standing Orders of the Council, shall be proposed except by the Governor or with his consent." The paragraph referring to the suspension of the Standing Orders was intimately connected with the principal terms of the clause, but had a wider significance in limiting the control of an unofficial majority.

The publication of the Letters Patent containing 


\section{THE BROAD STONE OF EMPIRE}

this amendment led to a resolution being moved in Council asking the Secretary of State to reconsider it. The argument mainly relied on in the discussion in favour of the resolution was substantially this: that the proposal of measures to revoke, alter or vary any disposition of or charge on the revenue would do no harm as it could have no effect without the consent of the governor, or could be vetoed by the Secretary of State. In defending the Letters Patent I relied on the terms of Mr. Chamberlain's Jamaica despatch, and on the practical inconvenience which had led up to their issue. Apart from these considerations, I pointed out a graver objection to the passing of resolutions or measures in favour either of expenditure or reduction of expenditure by a majority of the Council to be subsequently vetoed by the governor or the Secretary of State. Mr. Chamberlain had declared in the case of Jamaica that it is impossible, except when tact and goodwill and friendly feeling exist in an unusual degree, for the government of a country to be carried on when those who are responsible for it are in a permanent minority in the legislature. The procedure proposed must sooner or later be fatal to the continuance of such conditions. On these grounds I secured a majority in the Council and Mr. Chamberlain's support when a dissent signed by all the elected members was forwarded to him.

While I have illustrated some main difficulties inherent in the Mauritius type of legislature, which has now been introduced into India, I desire to record as the result of my experience that, where tact, goodwill, forbearance, and friendly feeling do exist, 
it is a type appropriate to a heterogeneous community of European, African, and Asiatic descent that has learnt to realise the letter and spirit of Queen Victoria's Proclamation to the Princes and Peoples of India in 1858 . I desire at the same time to record my opinion that in the Council of Government, as in the Executive Council, there has been nothing to choose between the political aptitude and ability of the two distinctive groups of the general community represented, as elected or nominee members, while the introduction of a representative of the Indian community has been of admitted advantage. What is really important is the outcome of work accomplished by the Council of Government of Mauritius and by the legislatures of the system of Crown colonies of which Mauritius is a unit. It is a main object of this work to show what they have done, and are doing, to develop the resources of the Crown colonies, to promote the physical, moral, and intellectual welfare of the people, and to make those colonies as essential to the Empire as the self-governing colonies. 


\title{
CHAPTER IX
}

\author{
LAW 1
}

I. ORIGINS OF LAW IN THE CROWN COLONIES

Within the varied regions of our Crown colonies there is found a mosaic of legal systems, bewildering in their number and complexity,- - here Roman-Dutch law, there the Custom of Paris or of Normandy, here the Code Civil, there Ottoman law, the law of Spain, or of medieval Italy. An Appendix to this work, on the Systems of Law obtaining in the Crown colonies (for which I have to thank Mr. Edward Manson, Honorary Secretary of the Society of Comparative Legislation,) presents, for the first time, an authoritative exhibition of the system of each colony, thereby giving my work a value which it would not otherwise possess. In a survey of

${ }^{1}$ In this chapter I have been assisted by the eminent lawyers who have been associated with me in dealing with the legislative and judicial problems of Crown Colony Administration; Sir JOHN CARRINGTON (formerly Chief Justice of Hong Kong) in British Guiana, Sir JoskPH Hutchinson (now Chief Justice of Ceylon) in the Windward Islands, Sir Francis PIGGOTT (now Chief Justice of Hong Kong) and Mr. Justice WoOD RENTON in Mauritius, as well as by Mr. EDWARD MANson, Honorary Secretary of the Society of Comparative Legislation. 
the origin and development of this complicated mechanism, it is necessary to keep in view the leading principles which have governed English policy throughout its career of conquest and colonisation. The essence of this policy has been to adapt itself to the peculiar requirements of every individual accession to the Empire, and our methods have been, consequently, as various as the communities for whom the legislation was designed.

The colonies which fall within the scope of the present inquiry are of two kinds, - those which have been obtained by settlement, and those which have come to us either by conquest or by cession; and our mode of procedure in regard to each of these two groups is necessarily distinct. The case of settlers is a comparatively simple one. Our policy is thus indicated by the Act of Settlement of William the Third:- "If there be a new and uninhabited country found out by English subjects, as the law is the birthright of English subjects, so wherever they go they carry their laws with them: and therefore such a new found country is to be governed by the laws of England." This principle is not confined to uninhabited countries. It was the basis of the old "factory" system established in many not necessarily barbarous countries where the settlers carried with them, "not only their own laws but the sovereignty of their own state; and those who lived among them, and those who became members of their community became also partakers of, and subject to the same laws." This has now been replaced by the more scientifically accurate system of exterritoriality, and 
the privileges of consular jurisdiction in a certain though diminishing number of oriental countries. An important qualification of this principle must be added, to the effect that such settlers take with them only so much of their laws as is applicable to their own situation and to the condition of an infant colony. The force of this reservation is, no doubt, subject to ambiguity; but the intention is a wise one, and although the new settlement starts somewhat trammelled by the inordinate intricacy of an older and more complex civilisation, yet it is free to develop in the way best suited to its environment and native genius, and in so doing may cut away the bonds which originally bound it by setting the law in order. Settlers are in any case exempt from the burden of future legislation in the mother country, since the grant of a charter conveys with it the provision that the common law and statute law of England, existing at the time of the grant, are alone applicable to the new colony, if it be not otherwise ordained by the express wording of a new law. Yet even this has its disadvantages unless the new legislation of the mother country be carefully watched, more especially in the matter of amendments or repeals of the old law, a point which will be referred to later. The charter further embodies the reservation quoted above, that this vast system of law and statute is only to apply "so far as circumstances admit." The application of this reserve is, of course, left to the decision of the judges who are required to act in accordance with "justice, equity, and good conscience," in other words "to apply, in such matters, such rules and principles of English 
law as they find to be applicable." 1 One example of this principle will suffice. It has been decided that the English Statute of Mortmain is inapplicable to the colonies, as having been passed to remedy a mischief arising from purely local circumstances in our own country.

The immediate needs of the new settlement being in this way met, the care of the future remained. A new Constitution involved a new legislative system, and although the provisions of the British Settlements Act of 1887 , which enables the Sovereign to legislate for occupied colonies by Order in Council, were not abrogated by its creation, the legislation of the future was, subject to guidance from Downing Street, left in its own hands.

The absence, under these conditions, of a preexisting lex loci, has, it will be seen, rendered the evolution of a legal system which should be at once homogeneous and appropriate to the nature of the new environment, a tolerably straightforward process. Where the initial position is different, as is the case in our colonies acquired by conquest or cession, our course becomes at once beset by a host of conflicting principles and interests. Our policy has been in the first instance to preserve the established law, at least in so far as it is not fundamentally at variance with our own conception of justice. For it would obviously be both inconvenient and unwise incontinently to replace the existing system by our own, and thus impose upon our new subjects a body of laws not only of which

${ }^{1}$ Burge's Colonial and Foreign Law (New Edition, 1907), vol. i. p. 64 . 


\section{THE BROAD STONE OF EMPIRE}

they were ignorant, but for which they might be both in civil and political character entirely unprepared. It was at the same time, however, still required by our English Courts, including the Judicial Committee of the Privy Council, that, where the law of a colony was alleged to differ from that of England, a sufficient proof should be adduced that this was the case. It will readily be seen that in these circumstances the position of our judiciary was everywhere involved in dilemma, and as late as 1833 so little were the laws in force in our colonies understood that it was the practice of the Master of the Rolls, who heard appeals to the Privy Council, to send the papers to some foreign jurist (in France, for instance, or Holland) and the opinion when obtained was adopted as the decision of the Court.

To sum up; in all settled colonies we find the common law of England to be the foundation of the local law. On this foundation each colony has erected and is erecting a superstructure of local statute law adapted to its own requirements, borrowing largely in the process from the mother country and from other colonies. Thus there have been adopted with trifling variations such codes of law as those comprised in the Imperial Bankruptcy Acts, the Companies Acts, the Sale of Goods Acts, the Partnership Act, the Bills of Exchange Act, the Merchant Shipping Acts, the Marine Insurance Act, and many more. There is in this way, especially in the sphere of mercantile law, a growing assimilation of the laws of the Empire. The Sale of Goods Act has been almost universally adopted, and Criminal Law and Procedure based on 
the Indian Penal Code is finding a wide acceptance. In other spheres the approximation, although growing, is less noticeable. Complete uniformity is not, however, to be expected, nor is it to be desired at the expense of the national individuality of the colonies.

II. LEGISLATIVE NEEDS OF THE CROWN COLONIES

A colony is England in little, and a cardinal principle of good government must be that it should possess a body of laws as complete in their own way and as perfect in detail as the mother country. Every one of our great industrial centres at home is in the full enjoyment of the entire structure of the English law, and it is as essential that each of these distant centres of life and commerce should be provided with an equally efficient machinery, adapted to its own needs. The protection of their rights and the just settlement of their disputes are of the same paramount importance; the contracts they enter into give rise to the same intricate problems; the wrongs they commit require the same subtle analysis as those which exercise the ingenuity of judges at home. The questions springing out of the local trade, though of the same nature as those which arise in England, are complicated by varieties of nationality, custom, and language; and as the colonial law affects the commercial relations between the mother country and the colonists it is of imperial concern that it should be in good order.

Our initial policy in regard to the settled colonies has been already indicated. The colony is launched 


\section{THE BROAD STONE OF EMPIRE}

on its way with the then existing law of England. It is obvious that the policy cannot be thus exhausted, but that it must continue to be the guiding principle of the future. Putting on one side local legislation to meet the peculiar needs of a colony, it is clearly necessary that the parting gift of laws should be kept up to date, and that changes made in the laws at home should be duly transferred to the colonies, in so far, of course, as they are applicable. If this is not done, the colonial laws must become antiquated, and statutes will be kept in force long after they have either disappeared or been amended in England. A concrete instance of this danger may be cited in a case which occurred not long ago in Hong Kong. The Statute I \& 2 Vict. c. I IO, provided that a judgment should operate as a charge on real estate. This statute, passed prior to 1845 , is in force in the colony. But there have been several amending statutes passed in England by which the law has been materially altered, the law affecting land having been assimilated to that affecting personalty in respect of judgments. But in view of the charter, which was as usual limited to the English statute law as it then existed, the amendments later than $\mathrm{I} 84 \mathrm{I}$ have no effect in the colony, and the antiquated law remains in force; although it had been clean forgotten until a busy solicitor discovered it, to cast a gloom over the profession,- - for who knew rightly what the effects of his judgments would be? This is by no means an isolated example. Over and over again problems of the most complicated nature arise which 
owe their existence entirely to the neglect to keep the colonial laws abreast of the time.

The methods by which they may be kept in current use may be broadly stated as consolidation and codification.

Consolidation is the term used for the combining of two or more statutes into one, with or without any alteration of their substance. It is usually done, and ought to be done, when a new edition of the statutes is issued. The editor aims at giving them in a more convenient form; and with this object he combines into one all the statutes which deal with the same subject; he takes each principal statute as a foundation and inserts into it, in a convenient form and order, the alterations which have been made in it by later legislation, omitting those parts which have been repealed or are no longer needed; correcting verbal mistakes or ambiguities; taking care that, except where a contrary intention appears, the same words are used throughout in the same sense, and that the same language is used to express the same meaning ; and simplifying and shortening the verbiage, which, as the statutes have been framed by various hands and perhaps have had amendments made in them without sufficient consideration in their passage through Committee, often requires verbal correction to bring it into harmony with other parts of the same statute, or with other statutes dealing with the same subject.

Sometimes in preparation for the revised edition it is desirable first to procure the passing by the Legislature of a new statute embodying several old ones. This happens when there are a number of 
so-called amending statutes the effect of which is in some points not clear, or when it is desired to take the opportunity of a new edition to make some small amendments in the substance of the existing law.

Codification is the putting into the form of a statute of laws which have hitherto only been found in text-books or reports of decided cases, or partly in such books or reports and partly in statutes. And since, in such laws, there are generally points of importance which are not definitely settled, or on which some amendment seems desirable, codification usually involves some change in the existing law. For example, the English law relating to bills of exchange, cheques, and promissory notes was, before I882, to be found partly in standard text-books, partly in reports, and partly in some statutes which had dealt with particular portions of the law; in 1882 the essential rules and principles of that law were codified by the Bills of Exchange Act ; and the Legislature in enacting the Code designedly made some alterations in the previously existing law, and settled some points which had previously been doubtful.

Thus consolidation requires chiefly scissors and paste, with a due amount of care and patience and a proper regard for symmetry and order : but codification requires in the draftsman of the Code wide and deep knowledge of many and varied authorities, literary skill in expressing in accurate and clear language the principles and rules to be derived from those authorities, and judgment in adopting the best rule where the authorities differ or are not clear. Accordingly the Legislatures of Crown 
colonies have often delegated to a Commissioner the task of preparing a new edition of their statutes, empowering him to consolidate where he thinks fit, and to make alterations in the language, and in the numbering and arrangement of sections, and the like, and to omit enactments which have been repealed or are spent; and they have enacted that the new edition, when printed, shall come into force and be the recognised Statute Book of the colony upon a proclamation bringing it into force being issued by the Governor. A Code has to be considered in detail by the Legislature before it can become law; and if the Legislature appoints a Commissioner to draft a Code, the Bill which he drafts has to be considered and, if necessary, amended and passed like any other Bill.

The consolidation and codification of old laws is only one aspect of the case. It is equally essential that when new principles of legislation are introduced at home, they should, when applicable, without delay pass on to the colonies. Take for instance such an important measure as the Married Women's Property Act. It should not be necessary to wait until a peculiarly distressing case of need should arise before the wise principles of that law are introduced. It is true that directly a case does happen, and the attention of the Government is called to the hardship which the absence of such a law has in a particular instance involved, the measure is at once transferred. But it is surely wiser to anticipate the evil. The example quoted is one which concerns only the individuals in the colony, but there are many cases where the benefits 


\section{THE BROAD STONE OF EMPIRE}

of uniform legislation operate within a much wider area. The absence of any definite machinery for calling the attention of the Government to such matters lies at the root of this defect. The question with which I am dealing has naturally not been overlooked at the Colonial Office; but its importance seems scarcely to have been fully realised. It often happens, indeed, that when some measure is passed at home which may affect the colonies, or which it may be desirable for them to adopt, a circular despatch is sent out asking for a report on its probable effect and working in each colony. This practice might seem to meet all requirements; but it falls short in a good many respects of what is actually needed. It is unsystematically carried out. It is only one of the multifarious duties of the Office's legal adviser; whereas there is need of a man's whole time to watch the operation of laws as they pass in England with a special view to the colonies. These despatches again are the terror of the colonial Law Officers, who seem expected to be, but cannot always be, men of universal learning and encyclopaedic knowledge. The answer often involves an immense amount of research and the consumption of a great deal of valuable time, owing to the fact that they are unaccompanied by any explanatory memorandum, sufficient to put the colonial officers on the track of what is wanted, pointing out the special features of the new legislation.

Another example of the importance of getting accurate information from the colonies may be cited. The Colonial Probates Act was passed in order to 
enable probates and letters of administration granted in England to have effect in the colonies by the simple process of resealing and vice vers $\hat{a}$. The Act was drawn on broad general lines, but in its working many difficulties inevitably arise, more especially in colonies where probates as such are unknown. The Act as drawn cannot have effect in colonies where the French law prevails, because there is nothing equivalent to probate in that law: and even in Hong Kong, where there is English law, one or more amendments of the original Ordinance have been found by experience to be necessary. In course of time the officer in charge of such matters at home would have a sheaf of amendments to introduce into the parent Act, in order to make it a still more serviceable one than it is. In the meantime, the individual suffers by the imperfect system. A man dies in Mauritius, for example, leaving a few shares in some English company. They are not of sufficient value to warrant the executor in taking out probate in England; but under the Act, if it could be extended to the colony, the expense of resealing being much less, the estate of the deceased would be so much the richer. As it is, the property becomes derelict for want of anyone with a title to take possession of it.

In regard to conquered or ceded colonies a further dilemma presents itself as to the interpretation of our original promise made at the time of acquisition. The cession or capitulation of such a colony is always accompanied by a proclamation that laws, customs, and religion shall be respected. The effect of this proclamation may, however, in 


\section{THE BROAD STONE OF EMPIRE}

certain cases be different,-for example in that of Hong Kong, which is a ceded colony, and in that of Mauritius, which comes into the category of conquered colonies. In the former of these the promise was made to Chinamen; in the latter, to the French inhabitants of the island. Yet the scope of the two proclamations is evidently different. The effect in the case of Mauritius was to continue the French laws for all future inhabitants of the colony; whereas, in that of Hong Kong, it could only apply to Chinamen; and an interesting question arises as to how far it extends to Chinamen coming into the colony after the date of cession. One point is clear, that in neither instance does the proclamation preclude the subsequent alteration of the law.

Again, in the case of Mauritius, there is much in the French Civil Code which is impossible of application to an English colony; yet there is no authoritative statement of how much is actually inapplicable, and until an expensive lawsuit has determined it, there is no means of knowing. The law of nationality may be taken to illustrate this point. The Code contains the old French law on the subject, which, it is needless to say, is based on principles entirely different from the English law. I have heard it gravely suggested that the British nationality of persons born in Mauritius is to be determined by the French Code,--which is not even in accordance with the modern French law on the subject. The solution of the difficulty is by no means an easy one. For even assuming the common law of nationality from its nature to over- 
ride the French Code, as it surely must, there still remains the question whether the nationality statutes of George the Second and George the Third apply to the colonies without express reference.

There are other subjects of great importance in respect of which it is hard to decide without long argument that they are not governed by the Code, and which are there dealt with on principles quite at variance with the English law,-the prerogative right of the Crown, for example, to precedence over creditors of equal degree. This question led to extraordinary difficulties in the case of the failure of the Oriental Bank. In the case of Lower Canada, the Judicial Committee held that this prerogative is overridden by certain provisions of the Code. The Court of Mauritius has held the same principle to apply to that colony. The prerogatives of the Crown are thus curtailed in a conquered colony in a way which was certainly never intended. This strange result, that in a Crown colony the Crown should be deprived of some of its prerogatives, is the direct consequence of the absence of any systematic control over the subsequent operation of the old policy of leaving the national law in force. It is unnecessary to multiply instances of the inconvenience which results from the want of any method of systematic revision and surveillance of the fundamental law, and which certainly mars in its application one of the best and most temperate policies in the world.

One thing is obviously necessary after the laws have settled into working order under the new conditions : an authoritative statement of how much of the old law is actually in force. There must 


\section{THE BROAD STONE OF EMPIRE}

follow a gradual elimination of so much as is unsuited to the needs and position of an English Crown colony ; and after that again, a gradual assimilation of the law on points which it is of importance to the colony as part of the Empire, and to the Empire having the colony as an integral part of it, to determine by identical, or approximately the same, legislation in the colonies and in the mother country. In the first category I include all questions affecting the Crown or State; in the second category I include such laws as those affecting merchant shipping, bills of exchange and other commercial documents, patents, trade and merchandise marks, and copyright; these are essential. Others are only expedient, such as the law on companies, bankruptcy, and Court Procedure.

Apart from these and kindred subjects, there seems to be no particular harm in the fundamental legal system of a colony being different from the English. There are, in fact, many things in French law, for example, altogether admirable and worthy to be introduced into our own, or at least to influence it,- - such as the system of registration of deeds or even the whole notarial system, the law of mortgage, which is infinitely simpler in its procedure than our own cumbersome method, and such institutions as the Curator of Vacant Estates and the Public Prosecutor. The Ministère Public, it may also be noticed in passing, is a far more useful institution in a small colony than an ordinary Law Officer.

A close analysis will often show that the two laws, though working from different fundamental definitions, often approach to the same point, and 
the remaining difference is not always in favour of English law. Good examples of this are to be found in the rights of tenants to improvements in regard to land, and the law as to the prima facie liability of the tenant in the case of fire against which he specially insures,- - the risque locatif. It may seem strange at first sight that an English Insurance Company should do business in one part of the Empire subject to a law different from that which governs its risks in another; but after all it is quite optional for an English company to come into rivalry with the local companies.

In advocating uniformity of legislation, it must be remembered that in the Crown colonies there is a large class of legislation in which uniformity or assimilation to the laws of the mother country is impossible. I mean legislation affecting the religion and personal law of the Indian and other nonChristian communities. The laws affecting Asiatics imported into British colonies under contract will be dealt with in another chapter. There is one class of legislation in which uniformity is almost as difficult among the Christian as among the non-Christian communities,- - the legislation governing marriage and divorce.

The fabric of the national life of Christendom properly rests on the divine foundation and sanctity of the marriage union. And yet, in spite of all professions, the nations and creeds of Christendom are divided in respect of important points. A marriage approved by the professors of one denomination of Christians is condemned by another as incest, and its children branded as bastards. There is nothing 


\section{THE BROAD STONE OF EMPIRE}

in the profession of Christianity that so shocks the intelligence of non-Christian communities. For among them marriage is as much the foundation of society as it is with us; the development of the institution of the family on regular lines is as much the care of their systems of law as of ours; the infringement of those lines as much reprobated by their society as by ours. If the Christian communities of the Empire could be persuaded to union or even tolerance in respect of its marriage laws, it would be a gain to the cause of Christianity of inestimable value, but legislation based on any such union seems at present to lie outside the domain of practical politics.

Some idea has now been given of the scope for legislative reform in the Crown colonies, and it may be well to indicate the lines upon which such reforms may best be carried out. The work to be done is of two kinds, Colonial and Imperial; and each part would require to be undertaken by the Government concerned,- - the primary object in both cases being the attainment of the greatest possible degree of uniformity of the law in regard to matters of Imperial moment, while at the same time preserving a just recognition of the claims of local custom, where this can be maintained without prejudice to larger interests.

Sir Francis Piggott has been good enough to draw up a group of suggestions for carrying out a comprehensive scheme of legislative reform for the Crown colonies. I submit them, as of undoubted value from the varied experience that has prompted them, in an Appendix. 
Having dealt generally with the principles of consolidation and codification of the laws of the Crown colonies, I proceed to give some account of what was actually accomplished during a period of a few years, and within the range of my own experience, by a small group of colonial jurists co-operating with three distinguished law officers and judges, Sir John Carrington, Sir Joseph Hutchinson, and Sir Francis Piggott.

\section{BRITISH GUIANA}

In the year I891, the Attorney General, Mr. (afterwards Sir) John Carrington, called attention to the necessity for a revision of the laws of the colony. The actual condition of the laws he showed to be one of "confusion, contradiction, repetition and disorder." Many Ordinances had been repealed or altered and amended by subsequent legislation, and the law relating to any given subject of importance could only be found spread over a series of years and a large number of separate enactments. Consequently, it was not always easy to ascertain which was the existing law on any given point, and to harmonise and apply it when ascertained. A notable instance of this had occurred in the case of the Inmigration Law of the colony, to which I shall call attention in another chapter of this work, and this no doubt led the unofficial members of the Court of Policy and Combined Court to support Sir John Carrington's proposals. It met with little encouragement from the Executive at the moment, for reasons which need not be specified, but I was satisfied that "some attempt must be 
made to simplify the task of learning the laws by improving their expression and arrangement." Accordingly, I availed myself of the first opportunity, when administering the Government in $189 \mathrm{I}$, to propose to the Secretary of State an arrangement for the early commencement of the work of revision by Sir John Carrington, who had in $188_{3}-85$ prepared a revised edition of the laws of Tobago, and in I $887-89$ a revised edition of the laws of St. Lucia. In September, I891, I was able to inform the Court of Policy that the Secretary of State had approved the arrangement. The Court of Policy at once unanimously agreed that the cost should be charged to funds voted by the Combined Court for the purpose. A little later, Sir John Carrington was appointed Commissioner for the revision of the Statute Laws of the colony with wide powers. The general principles on which the revision was to be undertaken have been already fully dealt with in what has been said on the subject of consolidation and codification of law in the Crown colonies. In the preface to the revised edition, published in I 895, Sir John Carrington explained how he had exercised the powers conferred upon him, in the following terms :

"These powers have been exercised principally in the following ways, namely, the consolidation of enactments in pari materia, the omission of introductory words of enactment in several sections of the older Ordinances, the rendering of the phraseology of enactments more simple and direct, where this could be done without affecting the sense, the breaking up of long and involved sections into sub- 
sections, the rewriting of marginal notes, so as to render them shorter and clearer, and the addition of marginal notes and foot-notes, of reference and information. The object steadily aimed at in the exercise of these powers has in fact been that which, it is conceived, was present to the mind of the Legislature when the Ordinance entrusting the powers to the Commissioner was passed, viz., that the new edition should, as far as practicable, be simple and clear in its language and uniform and convenient in its plan and arrangement. Of the powers above referred to by far the most valuable and important is that of consolidation. To those who are charged with or concerned in the administration of any particular branch of the Statute Law, it cannot be otherwise than an advantage to have the Ordinances and portions of Ordinances in which that branch is embodied, amounting, as they do in many cases, to two, three, four, or more, -in one case, nine-in number, brought together within the compass of one Ordinance. In the operation of welding such scattered Ordinances into one, it has, in some instances, not been easy to say what is law and what is not law, in consequence of an apparent preference having been sometimes shown for implied as compared with express repeal.

"But while these extensive powers of revision as to the form of the laws have been freely exercised, the Commissioner has carefully borne in mind, and anxiously endeavoured to conform to, the injunction laid upon him by the Legislature, that he should not, of his own motion, introduce into the edition 


\section{THE BROAD STONE OF EMPIRE}

any alteration in the substance of the laws comprised in it.

"The Chronological Table and the Index contained in the fifth volume are to a considerable extent modelled upon the Chronological Table and the Index to the Acts of the Imperial Parliament which are periodically prepared, printed and issued under the direction of the Statute Law Committee.

"Much time and labour have been expended in the preparation of the Index, and it is hoped that it will prove to be fairly full and complete and at all events accurate. The general scheme of it, as of the Index above referred to, is 'to group under comparatively few effective titles the whole of the Statute Law, and to refer by cross titles to the sub-divisions of that Statute Law as found under the proper effective titles." "

Upon its publication, the revised edition became "in all Courts of Justice and for all purposes whatever the sole and only proper Statute Book of the colony with regard to the Ordinances inserted therein," and remained in force until 1904. Already by that time it was found that so many laws had been repealed, amended, and re-amended, that again the law on any given subject could only be found by reading together several Ordinances. Accordingly, the preparation of a new edition was decided on and entrusted to the then Attorney-General, Sir Thomas Rayner, by whom the work was completed in 1905 , as far as possible on the same lines as the previous edition. Sir John Carrington has related 
that before he undertook his revised edition, the librarian of the Colonial Office had called his attention to the fact that British Guiana occupied the rearmost, or almost the rearmost, position among British Possessions in the matter of law revision. It may fairly be said now to occupy the foremost or almost the foremost place.

\section{THE WINDWARD ISLANDS}

In 1893 I was appointed Governor of the Windward Islands, and it was not long before I arrived at the conclusion that consolidation and codification of the laws was as necessary as it had been found to be in British Guiana. On a vacancy occurring in the office of Chief Justice of Grenada, I urged the Secretary of State to select an officer qualified to undertake the work and to make it a condition of the appointment. In 1894 Sir Joseph Hutchinson was appointed, and I may add that no appointment could have been more fortunate.

Sir Joseph Hutchinson had had valuable experience in West Africa. As Chief Justice of the Gold Coast, he acted as Chairman of a Commission appointed by the Governor to take evidence and report on the native law of the colony. In 1893 he undertook the preparation of a revised edition of the Gold Coast Statutes, and with that object prepared a Criminal Code which became law, and drafted some other Bills. It was desired, amongst other things, to define more clearly the powers and jurisdiction of the native chiefs and their courts: their jurisdiction in criminal matters was to be limited to minor offences; the methods of enforcing 


\section{THE BROAD STONE OF EMPIRE}

obedience to their orders and of executing sentences, and the question of appeal from native courts, were to be settled. It was decided as far as possible to maintain the authority of the native chiefs. Among the Bills prepared was one for the purpose of defining the power of individuals and heads of families and chiefs to dispose of the family or "stool" land,-a matter then becoming urgent in consequence of concessions which were being made on a large scale by the chiefs to European speculators and mining and timber companies. Before the Bills could become law, Sir Joseph Hutchinson was promoted to the Windward Islands.

The last collected edition of the laws of Grenada had been published in 1875 , and the Chief Justice, at my request, prepared for me two tables; one showing the laws repealed or disallowed or spent or expired; the other showing the laws still wholly or partially in force. After much consultation it was decided that the new edition should not be a mere reprint of the laws still in force, but that, where several Ordinances were in force relating to the same subject, they should be consolidated by simply incorporating the amending enactments in the principal enactment, or, where further amendments were to be introduced, by new Ordinances to be enacted by the usual legislative procedure. This was in accordance generally with the course adopted in British Guiana.

By an Ordinance subsequently passed, the Chief Justice was appointed a Commissioner with statutory power to deal with the enactments to be consolidated without further amendment. 
In the meantime, the drafting of the new Ordinances was rapidly proceeded with. They covered a very wide range. They included a revision of the Supreme Court Ordinances; a Code of Civil Procedure to regulate procedure both in the Supreme Court and in the Magistrates' Courts; a Criminal Code, based on the Criminal Code of St. Lucia, to simplify and embody a number of enactments scattered through other laws; a Code of Criminal Procedure,- to regulate procedure in the Supreme Court and in the Magistrates' Courts. Other new Ordinances were to be enacted to consolidate and amend the Ordinances relating to Police and Prisons, the Medical and Health Department, Marriage and Civil Status, Customs and Internal Revenue.

While making arrangements for the revision of the laws of Grenada, I was no less anxious to secure by the same methods uniformity of legislation in St. Vincent in all matters connected with the administration of justice or in which there was a community of interest. Accordingly, I invited Mr. Thornton, Attorney General of St. Vincent, to Grenada, in order that he might work with Sir Joseph Hutchinson in the preparation of identical Bills. In this way I was enabled in May, 1896 , to submit to the Secretary of State a Criminal Code, a Code of Criminal Procedure, and an Evidence Ordinance. The remaining Ordinances were proceeded with in the usual course, and the important work completed in I 898 . Before passing from the subject of Sir Joseph Hutchinson's work in the Windward Islands, I may add that, on his transfer to Cyprus, he acted as one of two Commissioners 


\section{THE BROAD STONE OF EMPIRE}

who prepared by similar methods a revised edition of the local Statutes passed since the British occupation in 1878 . It came into force in 1907.

The Codes of Criminal Law and Procedure of Grenada and St. Vincent are based, as were the revised British Guiana Codes, on Sir J. FitzJames Stephen's Criminal Code. In Sir Henry Taylor's Autobiography, there is an interesting reference to this Code. In I 869 the work of constructing a Penal Code for all the colonies in which the legislative authority of the Crown was paramount was entrusted to Mr. Robert S. Wright (afterwards Mr. Justice Wright). After three years of unremitting labour a Code was produced and for ten months was under revision by Sir FitzJames Stephen. Conferences and discussions followed, leading to a concurrence on almost all the important points of difference; and in 1875 the Draft Code was placed in the hands of the Secretary of State. In a note dated December, I 884, Sir Henry Taylor made a notable comment :

"What has become of it I have never heard. It was sent out to all the Crown Colonies, and the authorities of Jamaica at least, if not of the others, were ready and desirous to enact it, when a postponement was directed by the Home Government, I believe in order that Sir FitzJames Stephen's Criminal Code for England might take precedence, and any results of the discussion of that Code might be available for the improvement of the other. ${ }^{1}$

1 The Code was actually placed in the Statute Book of Jamaica, but it contained a suspending clause, and the suspension was never removed. 
How many years may pass before the British Legislature can be got to adopt such a measure as a Criminal Code for England, no one can tell, and in the meantime the benefits which the Crown Colonies might derive from theirs are thrown away. Such was the fate for no less than twenty-three years of the Indian Code constructed by Lord Macaulay and his brother Commissioners, during which years more than two hundred millions of our Indian subjects were deprived of the inestimable benefits conferred upon them when it was enacted in $1860 . "$

I am glad to have been able to contribute, if late in time, towards conferring on some of the Crown colonies the benefits of what Sir Henry Taylor rightly described as "an approved work of much moment and magnitude in the history of criminal jurisprudence."

Throughout the preparation of the Criminal Code in the Windward Islands, as elsewhere, I interested myself very earnestly to substitute for many enactments of cruel severity penalties in accordance with the more humane spirit which has influenced legislation in recent years. In particular, offences were classified and the maximum penalties in practically all cases reduced, the maximum sentence of penal servitude being limited to fifteen years. I have ever striven to follow the change in the opinion and practice of judges as to length of sentences that has taken place during the last quarter of a century. This change led to the appointment of an International Commission on Sentences by a Congress of Comparative Law held in Paris in 1900. This Committee agreed on a "questionnaire" as to the 


\section{THE BROAD STONE OF EMPIRE}

principle and practice of Courts in this respect, circulated, in English, by Mr. Montague Crackanthorpe, and in French, by his French colleagues, in all civilised countries. Summaries of the English and French answers have been published, and, though no formal report has been issued, the practice of judges has no doubt been influenced by the inquiry. It was natural that in the Crown colonies the deterrent theory of punishment should have survived the days of slavery and the use of the lash, resorted to with frequency and severity. My influence has always been exercised in limiting the use of the lash as well generally as in offences against prison discipline. It was a subject to which Mr. Chamberlain drew much attention, and I am sorry to observe that there seems to be in some Crown colonies a reaction against his views.

\section{MAURITIUS}

In few colonies has the codification of the laws presented greater difficulties, and in few has it been undertaken with greater energy than in Mauritius during my tenure of office as Governor. This was owing to the indefatigable industry and ability of Sir Francis Piggott, who held the office of Procureur and Advocate General, and the co-operation of members of the Parquet and of the legal profession, among whom I may mention Sir William Newton and Mr. Guibert, leaders of the Bar.

In 1897 Sir Francis Piggott, with the zealous aid of his assistants, had completed a few days before I assumed the Government, a revised edition of the laws, and had accompanied it by proposals for 
codification. The revised edition had cut away much dead matter from the Statute Book, and had grouped what was extant according to subjects. But the extant laws contained a great deal of matter which the revision could not touch. Some Ordinances had been partly repealed and others amended in not a few important particulars. To enable the revised edition to be consulted with advantage the editor had been obliged to insert many explanatory marginal notes and footnotes, and the revision still remained cumbrous and inconvenient.

In the scheme of codification prepared by Sir Francis Piggott he was compelled, for reasons already given, to omit for the time the three French Codes in force in the colony, the Civil Code, the Code of Civil Procedure, and the Code of Commerce. The codification of the remaining laws presented considerations peculiar to the colony. They included three groups; laws promulgated in the French language, from the earliest period to 1832 ; laws promulgated both in English and French from 1832 to $184 \mathrm{I}$; laws promulgated in English from 1841 to date. In many cases laws dealing with the same subject had been passed in two or even all three periods, and this had led to discrepancies not only in language but in principle. For instance, the Criminal Code passed in 1838 was based on the French Penal Code. In 1853 a Code of Criminal Procedure was passed, based entirely on the English Criminal system, apparently in complete disregard of the Criminal Code,-certainly with very little relation to 


\section{THE BROAD STONE OF EMPIRE}

it. An indictment for murder had to be drawn on the English principles in direct conflict with the articles of the Criminal Code which define the crime of murder.

Again, the laws of the French period still extant dealt with many important subjects, including the fundamental laws on registration, transcription and mortgage, notaries, and brokers. These laws were promulgated in their French shape without any alteration to make them workable in the colony. They had been amended over and over again in the English language, which did not tally with the technical terms of the old French laws; and the available texts were merely manuscript copies of the French laws written by clerks not always conversant with the French laws, and were full of grammatical and clerical blunders. In I 84 I an Order in Council declared that in future all laws should be made and promulgated in the English language, and that the French versions should be taken to be published only for the information of the inhabitants. During this period, as during the French period, important English laws, such as the Companies Act, were introduced in their original shape, without sufficient care to bring them into harmony with the colonial law and colonial circumstances. Accordingly, the work of codification was proceeded with, and in December, 1902, Ordinances were passed "for promoting the Revision of the Law by repealing enactments and parts of enactments which have ceased to be in force or have become unnecessary," and "for further promoting the Revision of the Law by amending parts of Ordinances which have become 
obsolete." In a little more than five years from the time when the work was commenced, a codified edition of the laws of the colony, within the limits indicated, was completed and published.

I have always believed the criminal law of the colonies to be a matter of the highest imperial concern, and it was my hope that a complete revision of that law might be completed before I left Mauritius. But the work presented almost insuperable difficulties, arising largely out of the fact that the Criminal Code of the colony was based on the French Penal Code and the Code of Criminal Procedure on the English system. There was a natural disinclination in the colony to abandon principles of the French Code, which varied considerably from the principles of the English Criminal Law, and this gave rise at times to lengthy discussion and controversy. Still, substantial progress was made. Many antiquated sections of the Code were excised, and the law codified in respect of some important amendments made at various times. This had the result of getting rid of the French translation of many sections which the Supreme Court had treated as part of the original text, the version most favourable to the prisoner being always taken to be the law. In addition, the Code was largely revised in accordance with the more humane spirit of modern legislation. As in the Windward Islands, the maximum penalties were in nearly all cases reduced, the maximum period of penal servitude being brought down to fifteen years; minimum penalties were abolished; the law affecting juvenile and first offenders was materially modified, and the severity 


\section{THE BROAD STONE OF EMPIRE}

of the penalty of flogging reduced to its lowest expression.

Coincidently with his labours in the codification of the laws of the colony, Sir Francis Piggott undertook a work of wider importance, a collection of Imperial Statutes applicable to the colonies. I close this record with a note in which he has described the genesis of the work;

"There are laws being continually passed by the Imperial Parliament which affect the Colonies, for although the local Legislature may pass laws for the peace, order and good government of the Colony, and although the King may under the British Settlements Act for settled Colonies, and in virtue of his prerogative for Crown Colonies strictly so-called, legislate by Order in Council, the Imperial Parliament never abandons its right to legislate for them too. I set to work in light-hearted fashion one day to make a list of these statutes applicable to the Colonies. In process of time, the list grew and grew till it developed into a book of some 700 closely printed pages, to which, after having revised them and excised all dead parts, I gave the name 'Imperial Statutes applicable to the Colonies.' To this was added a second volume of nearly the same size containing the statutes of special application to individual Colonies. It is a strange collection and reveals many laws which assuredly no one ever dreamed could still be extant. The Postmaster General apparently has still some unrepealed and somewhat mysterious powers over colonial posts, but whether he knows of them, or ever exercises them, is exceedingly doubtful. The most extra- 
ordinary thing that I came across, however, is that there are a whole series of obsolete statutes relating to coinage offences dating back to the 27 th year of Edward the First which are apparently still in force in the Colonies owing to the careless drafting of the repeal clause of the Coinage Offences Act, I $83_{2}$, by which these old statutes were repealed, but which applies apparently only in the United Kingdom, whereas the old statutes were in force in the Colonies."

The Collection reveals many similar surprises.

THE CLEMENCY OF THE CROWN

The revision of the Criminal Code has a very intimate bearing on a question of great importance; the exercise by the Governor of the power to pardon or to reduce sentences. The older Criminal Codes of the colonies very generally imposed minimum penalties as well as maximum penalties of great severity. I understand that in the Ottoman Penal Code of Cyprus, excessive minimum penalties are still maintained, but that this is remedied by the High Commissioner's power to exercise the clemency of the Crown. I have taken an active part in influencing legislation to abolish the system of minimum penalties, believing the constant interference of the Governor to override the law in matters which may reasonably be left to the discretion of the presiding judge to be contrary to the public good. Even without minimum penalties, the range of discretion left to judges is wide enough, and it is found that they differ widely in the exercise of their discretion, some judges awarding the maximum sentence for 
offences which others treat with comparative leniency. But in the Crown colonies generally, the exercise of the Governor's power of pardon or reducing sentences has a quite exceptional area of activity in questions arising out of the labour laws, and particularly in the general status of the immigrant population. The immigration of communities composed mainly of adult males must of necessity produce an unnatural proportion in the number of males to females in the colonies, and this gives rise to crimes which have their origin in the consequences of this artificial sexual ratio. Of late years it has been a condition of immigration to fix a certain proportion of females to males, and the disparity in numbers, as the immigrant population increases by births while the older surplus males are dying out, is constantly diminishing. Intimately associated with this class of crime are crimes having their origin in the relations of the European, African, and Asiatic communities to each other. And these crimes not infrequently stimulate racial animosity in a way that leads to disturbance and riot. In such circumstances there lies no more serious duty within the large attributes of the Governor than the right exercise of his discretion in the use of the prerogative of the Crown. It fell to me when administering the Government of British Guiana to exercise this discretion in circumstances of exceptional difficulty.

I may premise that in exercising the Crown's prerogative of pardon which is delegated to him by his instructions, the Governor acts largely as an independent officer, especially in capital cases, even in the self-governing colonies. The question has 
given rise to much controversy in Canada and Australia. In Crown colonies the Governor is instructed, in all cases where sentence of death has been passed, in terms similar to the following, which I quote from the instructions issued to the Governor of the Windward Islands :

"The Governor shall call upon the Judge who presided at the trial to make to him a written Report of the case of such offender, and shall cause such Report to be taken into consideration at the first meeting thereafter which may be conveniently held of the Executive Council of the Island in which the trial was held, and he may cause the said Judge to be specially summoned to attend at such meeting and to produce his notes thereat. The Governor shall not pardon or reprieve any such offender unless it shall appear to him expedient so to do, upon receiving the advice of the said Executive Council thereon; but in all such cases he is to decide either to extend or to withhold a pardon or reprieve, according to his own deliberate judgment, whether the Members of the Executive Council concur therein or otherwise; entering nevertheless on the Minutes of the said Executive Council a Minute of his reasons at length in case he should decide any such questions in opposition to the judgment of the majority of the Members thereof."

The principal causes of controversy have been cases in which a pardon or reprieve might directly affect the interests of the Empire or of any country or place beyond the jurisdiction of the Government of the colony. In a particular class of cases, it is evident that the effect upon neighbouring colonies, 


\section{THE BROAD STONE OF EMPIRE}

the Empire generally, and foreign countries, of letting loose a highly criminal or dangerous felon to reside in any part of the world might clearly and not unreasonably give rise to complaints from without the colony.

On January 3oth, I889, Manoel Gonsalves, a British subject of Portuguese descent, was convicted of the murder of his paramour, a coloured woman, and condemned to death. The verdict of the jury was accompanied by a strong recommendation to mercy, confirmed by a petition they addressed to me on February 6th. In this they stated that the recommendation was "the outcome of their conscientious opinion founded on the whole of the evidence and fully justified by all the surrounding circumstances."

On February $4^{\text {th }} \mathrm{I}$ had received the following telegram from the Secretary of State:

"Manoel Gonsalves. The King of Portugal has appealed to the Queen for commutation of sentence. If jury recommended to mercy, sentence should not be carried out, or if any doubts justifying further consideration, sentence should be delayed to give time for full consideration. I may add that the King of Portugal makes his appeal on the ground of the jury having recommended the man to mercy, a course which is always recognised in England."

On February 7 th a meeting of the official members of the Court of Policy, who practically represented the Executive Council of the Colony under the then existing Constitution, was held to consider the matter on the notes of evidence transmitted by the judge who had presided at the 
trial, and who was present at the meeting. At this meeting the official members expressed their concurrence with the judge in his opinion that there was no sufficient reason to exercise the prerogative of mercy. I did not come to a decision at the time, but informed the official members that I would take time to consider. On the 9 th I informed the Secretary of State that I had commuted the sentence to penal servitude for life, and this decision was a few days later communicated by the Queen to the King of Portugal. Before stating the general principles on which I acted, I must explain that in the Royal Instructions for the guidance of the Governor of British Guiana in force at the time, the only rule laid down in respect of the manner in which the prerogative was to be exercised in the case of death sentences was that he must call for a report from the judge who passed sentence. Recently, however, the practice had been adopted of consulting the official members of the Court of Policy as well as the judge. But this practice had been observed subject to the rule laid down by Royal Instructions in the case of all colonies constitutionally equipped with an Executive Council, that in the exercise of the prerogative the Governor must decide either to extend or withhold a pardon or reprieve according to his own deliberate judgment, whether the members of the Executive Council concurred therein or otherwise. Although, as has been stated, the exercise of the Governor's deliberate judgment in opposition to the advice of his constitutional advisers in a self-governing colony had led to serious difficulty, in Crown 
colonies the sole responsibility of the Governor in such cases had never been disputed. As an historic fact, in British Guiana the prerogative had repeatedly been exercised by the Governor without any recommendation to mercy on the part either of the jury or of the presiding judge, and even in direct opposition to the advice of the latter.

The reasons which I conceive to justify the exercise of the prerogative are, generally speaking, three: The recommendation of the jury, the recommendation of the judge, or the public good.

Exceptional cases occur which do not fall directly within any of these categories; for instance, in a recent case, I had commuted the sentence of death passed on a criminal reported on the strongest medical evidence to be insane after the passing of the sentence. In considering the recommendation of the jury, it is necessary for the Governor to consider whether it appears to have been the result of mala fides on the part of one or more of the jurymen, or to have been influenced by national or political partiality or prejudice connected with any temporary passion or excitement. In the case of Gonsalves, the subsequent petition of the jury satisfied me of their bona fides, while the constitution of the jury rendered it impossible that their unanimous recommendation could have been tainted by the other vices I have indicated. In these circumstances, I accepted their recommendation, confident at the time, and confident still after long experience, that no Governor could rightly have come to a different conclusion. As regards the recommendation of the judge, when 
that recommendation has been in favour of mercy, I have never known a case in which it has been resisted, although no Governor whom I have ever known has considered the exercise of the prerogative to be limited by the assent of the judge. As regards the public good, Lord Granville, when Colonial Secretary, in a despatch to the Governor of British Guiana of January 3oth, 1869, had laid it down that the only grounds on which it is justifiable to commute a deserved sentence are such as may show that it is for the public good that it may be commuted. The argument advanced by the judge, and supported by the unofficial members of the Court of Policy, was that in the case of Gonsalves the public good demanded the execution of the death sentence on grounds which may be briefly stated.

The economic pressure of competition between the Portuguese, who had almost a monopoly of the retail trade of the colony, and the coloured population of African origin, had for a long time excited a sentiment of racial hostility ready at any moment to break out into open violence at the instigation of reckless or unscrupulous persons of either community. It was fostered by a vaunting spirit on the part of the Portuguese Press, - both in Portugal and in British Guiana-which had undoubtedly created an impression that the Portuguese were under the special protection of the King of Portugal, and had in this way secured immunity from the operation of the ordinary criminal law of the colony. In particular it was believed that in this way they had secured immunity from capital punishment on the 
ground that capital punishment had been abolished in Portugal. In the words of the presiding judge, "there was a saying or belief amongst the people, both Portuguese and Creole, that a Portuguese cannot be hanged." There was no real foundation for this belief. The records of the Supreme Court showed that up to that time there had been only two cases in which persons of Portuguese birth or family had been convicted of murder in the colony. In the year I875 one José Teixeira was found guilty of murder and executed. In the following year a Portuguese, by name Jacinthe Rodrigues, was found guilty of murder, but sentence of death was commuted contrary to the recommendation of the acting Chief Justice, by the same Governor, Sir James Longden, who had signed the warrant of execution in the previous case. Both cases were, of course, reported to the Secretary of State, and there was no reason to suppose that the Governor was influenced by any consideration of the nationality of the prisoner. I was unable, therefore, to concur with the presiding judge in his view that the public good demanded the execution of Manoel Gonsalves, lest the commutation of sentence should confirm the popular error; in other words, that a human being should be sacrificed to popular ignorance and prejudice. In my report to the Secretary of State I expressed a hope that no child of his or mine might ever fall a victim to so eccentric a sentiment of justice.

By a strange coincidence it had occurred that on January 28 th, two days before that on which Manoel Gonsalves was found guilty of murder and sentenced 
to death, an Indian coolie named Gungah was sentenced for the murder of his reputed wife. In this case also I commuted the sentence against the recommendation of the presiding judge and the opinion of a majority of the members of the Court of Policy, although my decision was strongly supported by the opinion of the Immigration Agent General. This case came within the category of crimes I have referred to as having their origin in the artificial sexual ratio of the members of the Indian community.

The two cases taken together might, it should seem, have convinced the judges, that each had been judged on its merits, but they took a different view. They sent a remonstrance to the Secretary of State in which they went so far as to claim the right of the presiding judge to call upon the Executive to make a public explanation in cases of the commutation of the capital sentence. It was in vain I urged that the admission of such a claim must interfere with the free exercise of the prerogative and lead to constant risk of controversy between the executive and the judicial authorities in a colony in which such controversies had formerly led to the gravest public inconvenience. One of the judges positively objected to my treating his communications as confidential, and constantly and publicly protested against my action. Not content with exercising the undoubted right of appeal to the Secretary of State, they claimed publicity for their protests and any communications which might pass between myself and the Secretary of State on the subject. 


\section{THE BROAD STONE OF EMPIRE}

While I received the support of the Secretary of State, it was inevitable that the views of the judges should become common knowledge and influence to some extent the unofficial members of the Legislature. Nor was it to be wondered at that injudicious and unscrupulous persons so worked on the sentiment of hostility between the Portuguese and the coloured population, that within a few weeks a trivial incident led to a disastrous riot. It was promptly suppressed, but not before property of the value of some $\delta 10,000$ had been destroyed, much personal injury done, and one life lost. Even the gravest concerns of public and private life are accompanied by comic incidents. In the course of the riot a proclamation was issued to the effect that the Magistrate was authorised to order the police to use their fire-arms on any persons found breaking into, plundering, or attempting to set fire to houses or property. This prompted a black "lady," who had been one of the leaders of the disturbance, to go to the Inspector General of Police, and ask whether it was really meant to "shoot fo' true." On being assured that it was, she promptly requested to be accommodated in a police cell. This strategic movement commended itself to the intelligence of many of her friends and had the happiest influence.

Two years later, on July 24 th, $189 \mathrm{I}$, when again administering the Government, I received a similar telegram confirmed by a Despatch of the Secretary of State, informing me that the Portuguese Minister had made a communication to the Foreign Office, 
on the subject of a Portuguese resident named Agrela, accused of the murder of an Indian coolie. It was added that Her Majesty's Government had decided to leave the matter to my discretion. The trial took place in due course, and the accused was found guilty and sentenced to death. Dealing with the matter in the usual course, and in the same spirit in which I had acted in the cases already referred to, I informed the Secretary of State that, after full consideration of every point at issue, including the interests of the Portuguese community resident in the colony, I could find no reason which would justify me in commuting the sentence. The Portuguese Minister was informed accordingly, and I am bound to add in justice to the Portuguese in the colony that they accepted and appreciated my decision.

\section{SOCIETY OF COMPARATIVE LEGISLATION}

I have so far dealt with the origin of Crown colony law and with the methods adopted to secure periodical revision of the laws of individual colonies with a gradual approach to such uniformity as is practicable both in substance and in form. While it has been left to the colonies to carry out the necessary legislation an influence of recognised importance has been exercised for the last fifteen years by the Society of Comparative Legislation. The Society was established in 1894 , at the instance of Sir Courtenay Ilbert, mainly for the purpose of obtaining and diffusing a knowledge of the course of legislation in different countries, but more particularly in the several parts 
of the Empire. The work of the Society has always been heartily approved by the Colonial Office, and in $1902 \mathrm{Mr}$. Chamberlain, by a Circular Despatch of August $2 \mathrm{Ist}$, invited both the self-governing and Crown colonies to adopt an organised method for the interchange of ideas and information between all parts of the Empire as to matters of legal importance and the promotion of unity of law and procedure. The method adopted has been briefly this. The Attorney Generals of the colonies have formed local Committees to act as branches of the Society in different parts of the Empire; and these Committees have secured the co-operation of local Law Societies and local Bars. Every Branch Society makes reports to the Home Society of all matters of interest, Bills introduced, Acts passed, and important decisions of the Courts. What is of permanent interest is embodied in the quarterly Journal of the Society, which thus reflects the legal ideas and transactions of all parts of the Empire. At the same time, each Branch Society sends complete sets of the Statutes of the colony to be housed by the Home Society and form the nucleus of a legal library of the Empire. On the other hand, the Home Society is partly supported by contributions voted by the colonial Governments. The Society justly claims that by this organised method of labour each member or part of the Empire may now easily ascertain the legislative methods and work of all other parts. The many Statute Books have, by means of annual summaries, digests, and indices published by the Society, been made accessible as they never were before. 
The activity of the Society has recently been consolidated in the publication of a work entitled The Legislation of the Empire, edited under its direction by Mr. C. E. A. Bedwell. It presents a survey of the enactments of more than eighty legislative assemblies in the British Empire. 


\section{CHAPTER $\mathrm{X}$}

\section{LABOUR}

IT has been observed that outside the domain of theology there is no subject which has given rise to such an amount of controversial literature as the question of the rights and wrongs of tropical labour. The expansion of Western civilisation has everywhere had the effect of displacing the native races. The process of ages, during which the inhabitants of temperate and especially of northern zones have struggled against the difficulties of their environment, has evolved a race strong of will, abounding in energy and enterprise, and above all fertile of brain in finding clues to the operations of nature and turning them to account by the application of science to economic uses. Further, the climatic conditions of their home, by compelling the race to provide in summer for the exigencies of winter, have developed the faculty of acquisition and the habit of accumulation. Accordingly, our colonists have had at their command capital, skill in organisation, and scientific methods of production. The energy which has been a motive of expansion has characteristically sought to avail 
itself of equal energy in developing the resources of the area of expansion. But the climatic conditions, which had been a main factor in determining their character, had unfitted them for the physical labour necessary to develop the resources of the heat-belt of the world, and their endeavours to supply the capacities they lacked form an instructive chapter in the history of civilisation.

Mr. Benjamin Kidd, in his work on The Control of the Tropics, has made some very pertinent remarks in relation to the migration of labour into the tropics.

"Nearly every tropical country, the economic development of which has been attempted, is at present struggling with the question of the supply of labour for the elementary operations of industry. As the economic pressure of civilisation to develop the tropics continues, the cry is everywhere going up for races able to sustain the burden of the development which the tropics are destined to undergo. In response to this pressure it is possible that we shall witness in the future almost as large movements of population in the tropics as history has already witnessed in the temperate regions."

Mr. Alleyne Ireland, in his work The Far Eastern Tropics, has shown to what an extent this migration has been carried by organised systems of imported labour.

"An examination of the economic position of all tropical Colonies reveals a fact of the highest importance in regard to the labour conditions of those countries, - namely, that, with the exception of Java, Barbados, Puerto Rico, Cuba, and India, 
there is not a single tropical Colony of any commercial importance in which the work is not being done by imported labourers. In order to make this point quite clear, I will give a list of the Colonies and Protectorates in which labour supply consists wholly or partially of imported Chinese or East Indians :-British Guiana, Trinidad, Mauritius, Fiji, Ceylon, the Straits Settlements, the Federated Malay States, British North Borneo, Natal, Sarawak, Sumatra; and to those we may add Queensland, which gets its labour from the Pacific Islands; New Caledonia, which imports Annamites; and French Indo-China, where arrangements are now being made to import Chinese labour. There remain the Colonies in Equatorial Africa, Dutch and French Guiana, New Guinea, the Philippines, and a few unimportant islands here and there, and there does not exist amongst them one of which it can be said that in relation to the capabilities of the land economic development has really commenced." On this I will only note that if labour is no longer introduced into Barbados, Puerto Rico, and Cuba, the labouring population is not of natural but of imported slave origin. The development of the Philippines by American methods of colonial administration is a problem of interest to every Power engaged in the struggle for the control of the tropics.

The causes of this migration may be easily understood. Modern researches into the natural history of the human race have recognised three main types: the Caucasian, including the white European and the brown East-Indian; the Mongo- 
lian, including the red American, the yellow Chinese, the Japanese and the Malays of Asia; the negro type, including many races of black men of many shades, mainly habitant in Africa. And similar researches have determined that colour has no relation to mental characteristics, being merely what I may call an anti-corrosive pigment resisting solar influences, and, in combination with other physical characteristics, enabling the coloured man to live in an environment in which the existence of the white race is limited to two or three generations.

In temperate regions, where the white man could work under the same conditions as in Europe, he has himself replaced the native,- the Red Man in America, the Maori in New Zealand, and the aboriginal of peculiar and isolated type in Australia. The future of the natives in the temperate regions of South Africa is a question of the day. In our tropical colonies it is otherwise. Experience has proved that their resources cannot be developed by the manual labour of the white man, and that the natural residents will not voluntarily lend themselves to steady work of any kind except under the economic pressure of necessity in crowded areas. It is evident therefore, that the development of our Crown colonies on the lines of modern civilisation can only be effected under the administration and supervision of our own people by races capable of enduring the fatigue of tropical labour.

Very few words will suffice to trace the history of the relations of the white man to the coloured races in its main outlines. The imperial adventurers of the sixteenth century who, "with profits as their lode- 


\section{THE BROAD STONE OF EMPIRE}

star and greed as their compass," first obtained absolute control over the most beautiful and fertile regions of America, exploited their resources by the labour of the natives in accordance with a policy which may be stated in three words, "submission or extermination," and the conditions of submission were hard. They included a threefold obedience to the State, to the Church, and to individuals of an alien race. To the State they were forced to submit in respect of institutions, and to the Church in respect of a creed to which they were by their nature, history, and inherited pride in the traditions of their past hostile or invincibly opposed. To individuals they were forced to submit as slaves, bound to labour under conditions for which their environment, working through the process of ages, had rendered them totally unfit. When this policy had brought about the practical extermination of the native races as instruments for the development of material resources, they were replaced by negroes imported from Africa, physically equipped for the labours to which the natives had succumbed, and forced to work under even severer conditions of slavery.

The abolition of slavery or compulsory labour in the British dominions proved the necessity of a new policy. It is certain that if the emancipated slaves could have been persuaded to carry on the elementary operations of agriculture, they would have learned in time that the cultivation of land leads to its acquisition, and they would have kept in their hands the natural wealth of the soil, which has in a large measure passed to a race which has supplanted them. The hopes of those who believed 
that the negro in personal freedom, under no economic pressure, would be found a willing and efficient agent in the labours of cultivation were disappointed, and it soon became evident that some of the most fertile regions of the earth must be abandoned or cultivated under a new system. The policy by which the British Government, and in particular Lord Grey, endeavoured to secure the adhesion of the emancipated slaves to the soil failed. Lord Grey's policy was based on a theory, still advocated, that the pressure of a small tax would compel the negro to work in order to obtain the means of meeting it, and that the process would encourage a general disposition towards frugal industry. The failure of this policy necessitated another, and the necessity has been enforced by the constantly increasing pressure of external forces generated in a cosmopolitan struggle for the control of the tropics.

The struggle for the control of the tropics, and in particular the scramble for Africa, have now for some years threatened the peace of the world, and are to a large extent responsible for the ever-increasing burden of naval and military expenditure. But in public opinion the struggle has been regarded almost solely as a conflict between the Powers for the control of territories to be exploited in their own interest. It is now being borne in upon the Powers that they have overlooked "the man who counts," the man qualified by the process of ages to develop the natural resources of tropical lands, or, more broadly, the heat-belt which lies between the northern and southern temperate zones. As the only man qualified 


\section{THE BROAD STONE OF EMPIRE}

is the coloured man, it follows that if the struggle for the control of the tropics has been a white man's question, the beneficial use of the areas which are the object of the struggle is a question of the relations of the white man to the coloured races. In the United Kingdom, and in our colonies, in Germany, in Belgium, the question is agitating parliaments. Indeed, the struggle for the control of the tropics has brought it within the range of practical politics in every civilised country. A few years ago it was dealt with by President Roosevelt, in a message to Congress, with characteristic energy. It is a phase of the labour question of no less importance to the peace and prosperity of the British Empire than the questions which concern the relation of capital to labour in the United Kingdom.

To meet the exigencies of the situation thus created, a new system had to be found, based on a recognition of the reasons which had displaced the old. Under the old system the African negro, who had succeeded the aboriginal, was in turn superseded by an Asiatic immigration of yellow men from China, and brown Caucasians from East India. But the conditions of employment were changed. To the age of compulsory service had succeeded the age of social contract. The new-comers were introduced under a system of voluntary short-term contracts which they accepted under the economic pressure of over-population in their country of origin. During the period of contract scrupulous care was taken to respect their religion and personal law, and to protect their interests against caprice or injustice on the part of their employer. At 
the expiry of the contract they had generally the option of return to their own country, a renewal of contract for a shorter term on more favourable conditions, or residence under laws according equal rights to every civilised man. The system has been carried on for more than half a century, perfected by a continuity of operation approved by both political parties. Originating in the West Indies, it was adopted under analogous conditions appropriate to local circumstances in Mauritius, Ceylon, and the Far East.

THE COLONIAL INTERESTS

It is clear that a sound judgment on the rights and wrongs of Indian immigration must rest upon a consideration of the threefold interests involved; the interest of the colonies, the interest of the immigrants, and the interest of the Government of India.

To what has been said in proof that the economic salvation of our tropical colonies depends on an adequate system of immigration there is little to add. Sir Philip Wodehouse, when Governor of British Guiana, (1857-1866) showed how it is bound up with every interest in a colony. He said that "Since he had come to the Colony he had endeavoured to continue immigration on such a footing as would do more good to all. His reason for so doing was simply because he believed that there was not a single class of the population of the Colony that was not vitally concerned in the continuance of immigration. It might be that every class did not derive equal benefit from the 


\section{I4 THE BROAD STONE OF EMPIRE}

introduction of immigrants into the Colony, but it was clear that all derived benefit. He believed that the estates could not be maintained if immigration ceased. The mercantile community, if the estates were abandoned, would find a cessation of trade; the public funds of the Colony would be distressed, and public officers would lose their salaries and their occupation in life; the mass of the population of the Colony would also suffer, inasmuch as the necessary consequence would be the loss of all those social, political, and civil institutions which, in point of fact, constitute civilisation."

\section{THE INTERESTS OF THE IMMIGRANTS}

In a lecture delivered before the Society of Arts in December, 1873, Sir Bartle Frere said of the labouring population of India: "The Bengal labourer with wages at $1 \frac{1}{2} \mathrm{~d}$. or $2 \mathrm{~d}$. a day, and no roads or canals to bring him food, is always terribly near the brink of starvation"; and again: "Though I believe the existing population of India is, as a mass, better fed than it was forty years ago, still there are large masses, especially in Bengal, living on the limits of starvation." These words may be taken as indicating the condition of things in India when the abolition of slavery created the necessity for an importation of labour into our tropical colonies, and led to the organisation of a system designed to reconstruct the fortunes of those colonies on the principles of free labour. The peculiar fitness of the East Indian labourer to satisfy the wants of our tropical colonies was shown by $\mathrm{Mr}$. Grierson, an officer deputed by the Government of India to 
enquire into the system, prior to the passing of the Indian Emigration Act of $188_{3}$.

"The Colonies importing Indian labour are in the belt of the Tropics. The only exception is Natal, which is sub-tropical. The conditions of life in those Colonies are much the same, viz., an equable climate, free from sudden or extreme variations, and an amazing fertility. The original natives of these countries, living for generations where life without labour was easy and pleasant, have developed into a type of human beings peculiarly unfitted for the higher forms of cultivation of the soil. When, therefore, European enterprise attacked these countries with the hope of carrying off the richer products of the earth, the indigenous natives were found unsuited for aiding them in the work. Coolie labour had accordingly to be introduced; and the only places where suitable labour was found to be available were India and China. Both these countries are sub-tropical, the greater portion being outside the tropical belt. Here the conditions of life are very different. The climate is anything but equable, and is subject to sudden and extreme variations. At one time the country is deluged by rain, at another parched for months together. Here life is impossible without labour. The most elaborate precautions have to be taken to obtain even a probable chance of raising a moderate crop; and the result is that the inhabitants of India and China have, in the course of generations, developed into human beings possessing considerable agricultural skill and a wonderful capacity for continuous hard work. The Indian's whole life is one long labour,- 


\section{I6 THE BROAD STONE OF EMPIRE}

he never has a moment's rest. . . . When an Indian coolie is transported to a tropical Colony, he finds himself in a place quite beyond his experience. He finds a soil capable of yielding good crops with hardly any cultivation, and he naturally applies to it all the labour and all the skill and industry inherent in him. The result is an out-turn such as would be impossible in India, and such as he had never even dreamed of before. Subsequent experience confirms his first impressions, and he rightly considers that he has found a place free from cholera and famine, of a warm equable climate, where his natural industry, if rightly applied, makes its possessor in a few years the owner of a large fortune."

Such was in brief the origin of coolie emigration from India to our tropical colonies,-European enterprise on the one hand in instant need of a steady and continuous supply of labour, on the other a vast population skilful, industrious, and frugal, yet chronically on the limits of starvation, exposed to constant outbreaks of cholera and to frequent famines, and without prospect of ever bettering their condition or raising themselves above a daily struggle for existence.

It was not long before a betterment in the condition of the emigrant was confirmed by competent authorities. It will be sufficient to quote the opinion of Lord Hobhouse, who, when a member of the Council of the Governor-General, declared that anyone who "studied the returns which we had of the doings of our emigrants in many parts of the world would find that, wherever they went, they became far more prosperous than they were 
in India; that a very considerable number of them returned to India, bringing with them substantial sums of money, and that of these some, not a very few, were so satisfied with their foreign life that they returned to the colony where they had made their money. These seemed very conclusive proofs that the direct effect of emigration was to improve the welfare of the emigrants. Its indirect effect was that a man returned to his home with independence and more self-respect; he had got a new set of ideas ... . which he would communicate to the people about him, and it was impossible not to believe that such influences, if continued for a length of time, and on a considerable scale, would do as much as anything could do to elevate the people of India who were affected by them." The investigation carried on by the Government of India, prior to the passing of the Emigration Act of $188_{3}$, confirmed the accuracy of the general statement thus enunciated.

\section{THE INTERESTS OF THE GOVERNMENT OF INDIA}

The interests of the Government of India are broadly indicated by Lord Salisbury in a despatch to the Governor-General in Council of March 24th, I 875: "Having regard to the greatness of our Indian population, and to the probability that, under the protection which the British Government affords from depopulation by war, and, as far as possible from famine and other evils, that population must continue very greatly to increaseespecially in the healthier and more densely populated parts of the country, where the numbers 


\section{I8 THE BROAD STONE OF EMPIRE}

already press on the means of subsistence, and the lowest classes are at all times little removed from want-it appears to me that, from an Indian point of view, it is desirable to afford an outlet from these redundant regions into the tropical and sub-tropical dominions of Her Majesty, where people who hardly earn a decent subsistence in their own country may obtain more lucrative employment and better homes. ... Under extraordinary circumstances-such as famine, flood, or other great calamities, when large numbers of the poorer classes are deprived of the means of subsistence, or are left without house and home-the Government officers might themselves engage emigrants for these Colonies which have agreed to receive people recruited under such circumstances. ... We may also consider from an Imperial point of view the great advantage which must result from peopling the warmer British possessions, which are rich in natural resources and only want population by an intelligent and industrious race to whom the climate of these countries is well suited, and to whom the culture of the staples suited to the soil and the modes of settlement and labour are adapted. ... In this riew also it seems proper to encourage emigration from India to Colonies well-fitted for an Indian population." This despatch of Lord Salisbury may be said to mark an epoch in the history of the system. For some years previous to 1875 it had formed the subject of enquiry by commissions in British Guiana, Mauritius, and elsewhere. Lord Salisbury's despatch, of which the crowning result was the Indian Emigration Act of ${ }_{1} 88_{3}$, led the 
Government of India to a close investigation of the conditions under which emigration was effected, and the facts collected by officers deputed for the purpose, together with the evidence of the Emigration Agents, removed doubts from many questions for which a true solution could not otherwise have been found. From the point of view of the interests of India, Mr. Grierson, in the report already quoted, was not less emphatic. "Surely emigration may be looked upon as an engine of immense power for good to India. The more safety valves there are for a pent-up population in time of famine, the greater chance there will be of saving life; and, if I may venture to offer an opinion on such a point, I maintain strongly that it is the Government's imperative duty to actively encourage emigration by every legitimate means in its power, and to let it be known far and wide that the Emigration Department is a Government one." It may be said that up to the time of the passing of the Emigration Act of I 883 the Government of India tolerated the system as a favour to the colonies, while from that date it has actively encouraged it as a power for good to India. The adjustment of the balance of area and population which becomes in this way possible is a matter worthy the consideration of the statesmen of the greatest Colonial Empire the world has ever seen.

I pass on to consider briefly the general principles of the system of emigration from India, and to illustrate its operation by records of my own experience. 
THE SYSTEM OF EMIGRATION

The methods by which the emigration of labour from British India to our colonial dominions and to foreign possessions has been conducted, during the last half century, have from the beginning been keenly criticised and often misrepresented and denounced. They have formed the subject of innumerable inquiries and reports by royal and locally appointed commissioners. It may, therefore, be assumed that some account of the existing laws of the system, together with a brief survey of the facts and principles of its working, will have a particular interest for those who are concerned in the practical issues involved in the possible extension of emigration from India on a scale of magnitude, as well as for many who take a general interest in the experiment of emigration as a remedial political agency.

In view of the substantial benefits accruing, as we have seen, on all sides, it might well be thought an easy task to transfer the labourer from India where he is not wanted, to the colonies ready to welcome him as the only hope of their embarrassed fortunes. And yet the organisation of a satisfactory system of emigration has been found a work bristling with difficulties. It has been asserted with truth, and consistently with a full recognition of the ultimate benefits of the system, that when emigration from India was first tried it failed, and failed disastrously. It was only after long experience and many years of experiment in the passing of regulations that the Home and Indian 


\section{LABOUR}

Governments were satisfied that the introduction of Indian labourers into our colonies conduces as much to the welfare of the emigrants as to the general prosperity and commercial wealth of the colonies.

The emigration from any part of British India of a native of India under an agreement to labour for hire in countries beyond the limit of India is subject to elaborate regulations. The great charter of the system was the Indian Emigration Act of I 883 , the provisions of which apply not only to emigration from India to British possessions, but to emigration from British Indian ports to foreign colonies. For the reason that I have no official or practical experience of the working of the system in foreign colonies, I desire to have it understood that the scope of my observations is limited to British possessions. The Act did not apply to emigration to the Straits Settlements, which is provided for by a separate enactment, or to Ceylon. Emigrants to those colonies are protected by Colonial Ordinances in the same way as emigrants under the provisions of the Indian Emigration Act, but the conditions under which natives leave India for Ceylon or the Straits Settlements, are essentially different from the conditions of their emigration to distant British colonies and foreign possessions.

The emigration of Indians to British colonies and foreign possessions is only lawful from ports declared to be lawful ports by the Governor-General in Council. At these ports the Government of every country to which emigration is lawful is represented 


\section{THE BROAD STONE OF EMPIRE}

by an Emigration Agent, whose appointment is subject to the approval of the local (Indian) Government. The control of the local Government over the transactions of the Emigration Agent is secured by the appointment for every lawful port of a Protector of Emigrants, who is a public servant within the meaning of the Indian Penal Code and liable to be suspended by the local Government. The duties of the Protector are to aid and advise all emigrants; to enforce the provisions of the Emigration Act, and of all rules made under it; to inspect on arrival all vessels bringing return emigrants to the ports for which he is Protector; and to inquire into the treatment received by the returning emigrants, both during the period of their service in the country to which they emigrated, and also during the return voyage. The Protector is assisted in his duties by a Medical Inspector of Emigrants, appointed by the local Government. It is a part of the duties particularly assigned to the Protector to give assistance and advice to returned emigrants. The wealth of the returned emigrant often excites the cupidity of his neighbours, and unless he can soon find a good investment, the attempts to get money from him under various pretexts, such as caste dinners, etc., and even by theft, become burdensome, and so many re-emigrate, after a few months, fairly disillusioned with Hindustan. ${ }^{1}$

The recruitment of emigrants is effected by recruiters licensed by the Protector to act under

${ }^{1}$ Report of Major Pitcher to Secretary to Government, North-West Provinces and Oudh, dated Lucknow, June 17 th, 1882. 
the orders of the Emigration Agents. The licence is issued for a year, and can be cancelled on the ground of misconduct at any time. The control of the Government over this recruitment is mainly directed to prevent fraudulent representations, and accordingly the recruiter is required to give to every person whom he invites to emigrate a statement, signed by the Emigration Agent and countersigned by the Protector, of the terms of agreement offered to the intending emigrant.

Before any agreement is executed the recruiter has to take the emigrant to a duly-appointed Registering Officer or to the Protector, by whom the intending emigrant is examined apart from the recruiter. If it appears that he is competent and willing to enter into the agreement and understands its nature; that he has not been induced to enter into it by coercion, undue influence, fraud, misrepresentation, or mistake, and that its terms are in conformity with law, the name of the emigrant is registered, with all such particulars as to his person and history as may be thought necessary to establish his identity, or for other purposes. After the registration of these particulars, an agreement is executed in triplicate by the recruiter and the intending emigrant, and attested by the Registering Officer or Protector. One copy is transmitted to the Emigration Agent, another is delivered to the emigrant, and the third becomes a record of the Protector's office. The emigrant, thus registered, is conveyed with all convenient despatch, accompanied by the recruiter or by a competent person approved by the magistrate, and provided with 


\section{THE BROAD STONE OF EMPIRE}

proper and sufficient food and lodging, to the depot established at the port of embarkation by the Emigration Agent. The depot is a licensed establishment, subject to inspection by the Protector of Emigrants and the Medical Inspector at least once a week, and practically under the control of these authorities. On arrival at the depot the emigrant is examined by the Medical Inspector to ascertain whether he is fit to undertake the journey to the country to which he has agreed to emigrate. After this examination power is given to the Protector, either on the report of the Medical Inspector or on other sufficient grounds, to rescind the engagement and to secure the payment to the proposed emigrant of the cost of his return to the place where he was registered. In certain cases it is provided that a reasonable sum by way of compensation shall be paid to the emigrant. If the Protector is satisfied as to his fitness, the emigrant is maintained at the depot until the moment of embarkation, the manner in which he is lodged, fed, clothed, and otherwise provided for and attended forming the constant care of the Protector and Medical Inspector.

The requirements of the Indian Government for the security and comfort of the emigrants on their voyage to their port of destination are, it is needless to say, stringent. They extend to the surveying and licensing of the vessel, accommodation and space, provisions, clothing, and water, medical attendance, medicines and stores; and every master of a vessel licensed under the Emigration Act is required, before any emigrant embarks on his vessel, to execute a bond binding himself and the 
owner of the vessel, under a penalty, to perform the duties imposed by the Act, or by Rules made under the Act, on master and owner respectively.

Arrived at his port of destination the emigrant passes under the protection of the Colonial Government. For his protection a special department of the Administration is established under an officer styled the Protector of Immigrants or Immigration Agent-General. The duties of the department are of the widest range, but in the first instance relate directly to his protection so far as concerns the proper fulfilment of the terms of his agreement executed in India. These may be grouped under the heads:-period of indenture, dwellings, wages, work, medical care and maintenance in sickness, return passages when claimable.

The conditions of agreement under these heads vary in different countries. Generally the period of indenture is five years. In some colonies coolies are allowed to reindenture, in others their industrial residence, as it is termed, terminates at the end of the original period of indenture. Everywhere the coolie is entitled to a free dwelling and garden ground, and it is the constant care of the Government that all needful requirements of accommodation and sanitation shall be observed in the construction and maintenance of his dwelling at the cost of the employer. The rate of wages varies according to the nature of the work, which includes the cultivation of the soil and the manufactures of the mill. The minimum daily wage for able-bodied adult males is generally about one shilling. There are many kinds of work at which larger wages can 
be easily earned when the immigrant has had practice and experience. In some colonies wages are partly paid in rations, and in all arrangements are made for the rationing of coolies in certain circumstances. The hours of work vary according as the work is in the field or in the factory buildings. The indentured coolie is always entitled to medical care and maintenance during sickness; and the hospitals provided for their accommodation place them in times of sickness in a position of singular advantage as compared with agricultural or urban labourers in Europe. In all the more distant colonies return passages are claimable after a continuous residence of ten years, five years having been passed under indenture; but a comparatively small proportion are claimed. As the Indian population in a colony grows, as children are born and families become bound to the colony by new ties, each succeeding generation becomes more and more firmly rooted in the soil. Of those who do return to India, a large number bring back their friends and relations to the land of their adoption.

Such are the essential conditions of the system under which natives of British India emigrate. Under many Indian and colonial Acts and Ordinances rules and regulations are made dealing in detail with almost every incident which may conceivably affect the person and property of a coolie. So far as concerns the supreme control of the Government of India over the system, it is amply secured by the power reserved to the GovernorGeneral in Council to prohibit emigration to any 
country to which it has been allowed, if he has reason to believe that any epidemic disease dangerous to health has broken out in the country; that the mortality among emigrants is excessive; that proper measures have not been taken for the protection of emigrants immediately on their arrival in the country or during their residence therein; or that the agreements made with them before their departure from India have not been duly enforced. Where India has command of the labour market it has ample power to ensure due protection for its emigrant subjects, and a simple threat of prohibition has often been found sufficient for the purpose.

\section{BRITISH GUIANA}

The question of an appropriate system of emigration has, of course, an interest in proportion to the extent of the undeveloped resources of a colony and the available labour supply. The area of British Guiana is generally estimated at about I I 0,000 square miles, not much less than the area of the United Kingdom, while the area beneficially occupied does not exceed 150 square miles, about the area of the Isle of Wight. The estimated population, exclusive of some thousands of aboriginal Indians, does not exceed 300,000 , mainly congregated, of course, in the small area beneficially occupied. The male population over fifteen years of age is estimated at about I 20,000 . It would be a waste of time to argue that in such a colony an appropriate and adequate population is necessary for the development of its resources.

In British Guiana, as elsewhere, the Emancipation 


\section{THE BROAD STONE OF EMPIRE}

Act was immediately followed by efforts to supply the deficiency of labour consequent on the withdrawal of the praedial slaves from the cultivation of the soil. The West Indian Islands offered the earliest source of supply,--emancipated slaves of African descent ; but this supply, pressingly needed at its source, soon proved inadequate. In I 840 the Home Government consented to immigration from British possessions in Africa, and this source was supplemented by the introduction of liberated slaves captured in transit mainly between Africa, Cuba, and Brazil. In 1867 the introduction of Africans into the West Indies was prohibited. Meanwhile in I 853 the first Chinese immigrants had been introduced. In 1859 an organised system of Chinese immigration under government supervision was established and continued until i 866 . In view of a more recent experiment in South Africa, it is interesting to recall that Chinese immigration was in that year suspended owing to a convention entered into by the Government of China and the representatives of Great Britain and France at Pekin, containing a stipulation that immigrants should, on the expiry of their term of contract service, be entitled to repatriation at the expense of the colony. The onerous burden thus imposed was subsequently partially modified, but since 1878 there has been no immigration from China.

Although introduced originally under contract of service as agricultural labourers, the Chinese did not long remain available as hired labourers for plantation work. As independent settlers they have exhibited the characteristic qualities of their race in 
obedience to law and order, in industry, thrift, and general sobriety. In towns and villages they have proved themselves formidable competitors in retail trade; in the interior they have established a settlement of their own under the name of Hopetown. As pioneers in colonial enterprise, they have taken their share of work, in agriculture, in the cultivation of rice and general provisions, in forestry as woodcutters and charcoal burners, as well as in exploiting the mineral resources of the colony. But the exigencies of agriculture, and in particular of the sugar industry, demanded a population more appropriate to the conditions under which the estates could be worked with advantage, and in 1845 the experiment of organised immigration from British India under the joint control of the Government of India and the Colonial Office was tried.

The first Ordinance to organise a working system of immigration was passed in 1843 , but it applied only to immigrants other than East Indians; in the following year, however, its operations were extended to Asiatic immigrants. It must be admitted that the system was undertaken with no adequate understanding of the complex problem it presented; and it gave rise to an incessant conflict between the planters on the one hand and the local Government and the Colonial Office on the other as to the conditions on which the system was to be worked. Some idea of the difficulties that opposed the system may be gathered from the patchwork of Ordinances enacted to meet the requirements of the Home and Indian Governments. Between I 843 and I 848 (both years inclusive) no less than fourteen Ordinances 


\section{THE BROAD STONE OF EMPIRE}

were passed with no more satisfactory result than that in 1848 immigration from India was stopped. The immediate loss to the revenue was enormous, and a general collapse of all financial engagements followed. In i 850, however, a series of Ordinances was passed and sanctioned by the Colonial Office, and in the following year immigration was resumed. But of the difficulties which still awaited the system a further idea may be gathered from the fact that between I 850 and $186_{3}$, both years inclusive, no less than forty-seven amending Ordinances were passed. In 1864 a consolidated Immigration Ordinance was passed, based on the experience of the preceding period of experiment and conflict. This Ordinance modified but did not arrest the energy of the Legislature; and between I 864 and I 868 it yielded ten further amending Ordinances.

In the year $1869 \mathrm{Mr}$. (afterwards Sir George) Des Vœux, who had for some years held the office of stipendiary magistrate in British Guiana, was temporarily acting as Administrator of St. Lucia. In that capacity, on December 25 th, he addressed a despatch to Lord Granville, Secretary of State for the Colonies, in which he made sweeping charges against the administration of the Immigration Laws in British Guiana, and condemned the whole system. The general tenor of these charges was described in The Anti-Slavery Reporter in these terms:

"He arraigns the medical men employed on the estates, the Stipendiary Magistrates, the Clergy in colonial pay, the Sub-Immigration Agents, and even the late Governor (Sir Francis Hincks), as subservient to the views of the planters, and opposed 
to the interest of the immigrants, whom he declares to have been long treated with gross deception, injustice and cruelty."

Sir Clinton Murdoch, Chairman of the Land and Emigration Commissioners, commenting on the charges, wrote:

"Mr. Des Vœux impugns the conduct of every class in the colony except the lowest; and imputes to the local government, previous to the assumption of the government by Mr. Scott, and the Magistrates, and Medical men, cruel neglect of duty, and unworthy truckling to the planting interest, and to the planters generally, cruelty, falsehood and perversion of justice."

Lord Granville referred the despatch to Sir Francis Hincks, who energetically protested against the assertions it contained and raised the pertinent question why Mr. Des Vœux had for years concealed the facts he now alleged from his official superiors. But Mr. Des Vœux challenged a Commission of Inquiry, and declared himself "ready and willing to provide strong evidence in proof of his facts, and in support of his opinions." The result was the appointment of a Commission with Mr. William Edward Frere, an elder brother of Sir Bartle Frere, as Chairman. He had lived for thirty-five years in India, had been a Judge of the Supreme Court of Bombay, and a member of the Governor's Council. The other members of the Commission were Sir George Young, an English barrister, and Mr. Charles Mitchell of Trinidad. Mr. Darnell Davis, a West Indian, was Secretary. The composition of the Commission was open to no 


\section{THE BROAD STONE OF EMPIRE}

reasonable objection. The inquiry was of the most exhaustive character, and every precaution was taken to allow the immigrants to speak freely in the absence of managers or white men employed on estates. Nor was the report less exhaustive. It filled four volumes containing in all 1600 pages. It has been justly observed that "no labour system could have been or ever has been subject to a more searching investigation; and no labour system could possibly have come more triumphantly through the ordeal." One of the results of the inquiry was to illustrate the carelessness with which charges have constantly been brought against the system of Immigration from India. Commission after Commission and Inquiry after Inquiry has confirmed this tendency on the part of individuals and Societies. On this subject, the Commissioners reported :

"Persisting, as we were bound to do, in the course that we considered to be most appropriate, we were informed by Mr. Des Vœux that he had not in possession, either now or when he wrote the letter, and never had kept any memoranda taken at the time and bearing on the matters in question; that he wrote his letter, in fact, without note or anything of any kind; and while he could, from memory, afford us very few facts, if any, in addition to the specimen incidents in that letter, it became in the course of our proceedings painfully evident, that in regard to these, upon which so much was left to depend, his memory had very constantly and still did very constantly betray him; so that, although perhaps in hardly any of them, as was to be expected, 
were all unsatisfactory circumstances finally and fully explained, on the other hand none of them as related were found to have been correctly stated in all material points."

These observations of the Commissioners were justified, as clearly shown in the report, in respect of every class of the community against which charges were made. But it will be sufficient to sum up the results of the inquiry in the terms in which Sir Clinton Murdoch, Chairman of the Emigration Branch, then a separate department of the Colonial Office, expressed his opinion :

"In conclusion, it may, I think, be considered that the report of the Commissioners is generally satisfactory, both as regards the magistracy, the planters, and the immigrants. Many defects in the system and mode of working it are no doubt pointed out, but they are defects caused by errors of judgment, by insufficiency of the law, or by want of foresight, not by intentional neglect or indifference to the well-being of the people, still less by oppression or cruelty. The vindication of the magistracy and of the medical officers from the charge of servility to the planters appears to be complete, and the fair dealing and kindness of the managers towards the immigrants is acknowledged."

The immediate result of the Commission was the enactment of a fresh consolidating and amending Ordinance, No. 7 of 1873 , designed to remedy the defects of the system thus indicated. It did not long arrest the legislative machine, which within a few days turned out a short amending Ordinance, and within the next few years produced many important 


\section{THE BROAD STONE OF EMPIRE}

measures. In particular, the Medical and Hospital Services were reconstructed on a scale of lavish generosity equally in respect of the salaries offered to secure the services of highly qualified practitioners and of the hospital accommodation provided. The financial result of these measures was that the public expenditure of the colony on the Medical Department and public hospitals amounted to over oneeighth of the total revenue. Of this amount nearly one-fourth was paid by the employers of immigrants ; and in addition, the expenditure on over ninety estate hospitals was entirely defrayed by the proprietors. When these hospitals were visited in 1891 by the Commissioner appointed by the Government of India, he reported: "Many of the estate hospitals are built and maintained on a scale which would be a credit to any large county town in England." By I 887 the system established in 1873 had been subject to ten amending Ordinances. Nevertheless, the enemies of the contract system of immigrant labour adhered with tenacity to their policy of endeavouring to destroy it. In view of the charges directed not only against the system but more particularly against the methods by which it was carried out, the planters courted inquiry, for two reasons; while anxious to justify their own conduct in the administration of the existing system, they desired a reconsideration of some of its provisions that experience had proved to be prejudicial, and a consideration of proposed amendments to perfect it. In 189 I Surgeon-Major D. W. D. Comins, an officer in the Medical Service of the Government of India, employed on special duty in British and 
foreign colonies, was deputed to visit British Guiana, to inquire into the working of the system and to report on any changes that might be required.

I must interrupt my narrative to say a word on the method of inquiry adopted. Investigations into the working of the Immigration Laws in our tropical colonies have been conducted generally by a Commission of two or more members or by a Commissioner. A Royal Commission is appointed by the Crown, a Special Commission usually by the Governor acting on instructions from the Secretary of State. A Commission exercises its powers independently of the Governor. I have given some account of the British Guiana Commission of 1870 . It will easily be understood that the charges made against every class of the community produced a general sense of indignation that embittered official and social relations throughout the colony. In $1872 \mathrm{Mr}$. Frere was appointed Chairman of a similar Commission to inquire into the working of the Immigration Law in Mauritius, with Mr. Victor Williamson as a colleague, and Mr. Darnell Davis as Secretary. I was in Mauritius at the time, holding the appointment of Rector of the Royal College, and I am able to speak with experience of the influence it exercised on the colony during the many months of its sitting.

The appointment of the Commission came about in this way. The Governor, Sir Arthur Gordon (now Lord Stanmore), had addressed to the Secretary of State a despatch, not intended for publication, in which he had shown that the administration of the Immigration system required serious attention. 


\section{THE BROAD STONE OF EMPIRE}

The Secretary of State, however, instructed the Governor to publish the despatch, and on its publication, the planters, considering it to imply a reflection on their public and private character, demanded an independent inquiry. Only a small group of the community, including certainly some who had the least reason to fear the results of any form of inquiry, deprecated the appointment of a Commission. They saw no reason why any needful reform of the Immigration Law should not be carried out by the Governor and the constituted authorities with the co-operation of the planters, and they were not unmindful of the conflicts to which the appointment of a Commission had led in British Guiana. This group was led by Mr. (afterwards Sir) Célicourt Antelme, an influential planter and a member of the Legislative Council. I believe that I am justified in saying that Sir Arthur Gordon shared their view, and it was certainly justified by the result. But the Secretary of State decided otherwise, and a Commission was appointed.

The consequences were unfortunate in the extreme. It must be borne in mind that the immigrant coolie in Mauritius is not confined, as is often supposed in this country, to the area of agricultural industry. $\mathrm{He}$ is employed in every department of public and private activity; he is engaged in every household. In the excitement and exasperation that followed the appointment of the Commission it was conceived that an inquisition was to be held not only into the administration of a system, but into the confidential concerns of every business and every household. The colony was at once divided into 
two camps, the Governor and his friends holding one, the planters and their friends the other. Each party was to the other the campennemi. The routine of public and private life was dislocated. The public departments directly concerned in defending their administration were the Parquet, the Immigration I)epartment, the Stipendiary Magistracy, the Police and the Medical Department; but in a colony the interests of all public departments are so intermingled that it was difficult for any official to keep out of the entanglement. And while the Heads of Departments were on their trial, there were not wanting subordinate officials ready to give away their superiors. In the concerns of business and private life the same thing happened. Informers, acknowledged or anonymous, abounded every where; espionage, gossip, and scandal were the environment of society. Distinctions of class, colour, and creed excited animosities that had slumbered. By much the most serious result of this conflict was that it introduced an element of discord between the Government and the unofficial members of the Legislature, and exasperated the latter and the general community against the Colonial Office to an extent seriously prejudicial to the public good. The consequences were to play an important part in the movement of a few years later for the reform of the Constitution. When at length, after years of delay, the Report of the Commission had been published, and its recommendations embodied in the Labour Law of the colony, the result did not materially differ from the result of the British Guiana Commission. At least I make bold to aver that the Commission led to no 
result that might not easily have been obtained by the Governor with the assent of the Legislature and the good-will of the whole community, had the method of friendly inquiry by a Commissioner, adopted by the Government of India in sending Dr. Comins to British Guiana, been substituted for an inquiry by Commission.

The mission of Dr. Comins was of an entirely different order. A fundamental condition of immigration from India into our tropical colonies is the joint control of the Colonial Office and the Government of India. In order to secure this, a Colonial Officer holding the appointment of Protector of Immigrants is placed in a position of independence as representative of the Government of India,-in fact, in British Guiana the Protector is styled the Immigration Agent-General. $\mathrm{He}$ is removed from the control or interference of the Colonial Secretariat, and exercises his duties in direct communication with the Governor. The appointment of Dr. Comins as a special Agent of the Government of India, made him de facto the head of the Immigration Department. The position was practically identical with that of inspectors of banks and commercial houses sent to control the working of branch offices. It has frequently of late been suggested that the Colonial Office should appoint Inspectors with analogous duties to be sent out to the Crown colonies to control the working of the Administration. Such was Dr. Comins's position. He was de facto Agent-General, while the routine of the Department continued to be carried on by the titular holder of the office. 
I may now explain my own position at the time. Early in April the Governor, Lord Gormanston, left the colony, and the administration devolved upon me with the duty of making arrangements for Dr. Comins's visit. My first concern was that he should have ready to his hand positive information as to the existing laws and regulations. It at once became evident that the.only effective way in which this could be done would be by consolidating and amending the various Ordinances enacted since the consolidating Ordinance of 1873 . The difficulties of construction arising out of a number of amending Ordinances with their repealing clauses had, in fact, become so great as to leave it a matter of uncertainty to what extent they were wholly or partially in force. Accordingly, the Attorney-General, Sir John Carrington, with the co-operation of the AgentGeneral, undertook to draft a Law to consolidate and amend the Laze relating to Asiatic Immigrants. Its main object was to bring within the four corners of a single enactment the whole body of law on the subject, including the law of marriage, contained in some twelve Ordinances, all, as the Attorney-General found, cutting into one another in a most distracting manner. At the same time, the Bill, while omitting some provisions of existing enactments which experience had proved to be prejudicial, included important provisions to perfect it. It was of necessity voluminous, containing 248 clauses. Some idea of its scope may be given by reciting the titles of the sixteen parts into which it was divided: The Immigration Department; Fiscal Provisions; Arrival and Allotment; Indenture; Dwellings; Rations; 


\section{THE BROAD STONE OF EMPIRE}

Hospitals ; Labour and Wages; Leave and Desertion; Marriage, Divorce, etc. ; Transfer and Determination of Indentures; Certificates of Exemption from Labour; Passports and Return Passages; Registers, Returns and Certificates; Procedure; Miscellaneous Provisions.

For the convenience of many who are interested in the question of immigration from India but have no opportunity of understanding the real nature and scope of the system, I give, in an Appendix, the full arrangement of sections published with the Ordinance.

The Bill was introduced into the Court of Policy and passed through its earlier stages before Dr. Comins's arrival in the colony, but the final stage was postponed in order that I might consult him. As it seemed almost grotesque that he should proceed with his mission without knowing what the Immigration Law of the colony really was, and as there was no other means of ascertaining it with any certainty, the Ordinance was passed on July 29th. To my regret I was instructed to pass a short Ordinance to postpone its operation until it had been sanctioned by the Secretary of State. I knew that this would mean a long delay; I did not realise that it was to mean a delay of years, with the almost incredible result that during that long period the laws upon which the immigration system depended were deliberately left in the confusion I have described. There were other unfortunate results, but I leave it to Dr. Comins himself to vindicate the Ordinance, and the method by which it was enacted as contrasted 
with the method adopted in Mauritius. In his report on his mission he says:

"The necessity for a revision of the obsolete Immigration Ordinance supposed to be still in force is urgent, if for no other reason than to legalise the alterations, nearly all of them to the advantage of the immigrant, which have been adopted from time to time. I may say that this Ordinance has been prepared with much care and consideration, under the supervision of Sir Charles Bruce, K.C.M.G., Lieutenant-Governor of British Guiana, who has the interests of the immigrants and the good of the colony at heart, acting in concurrence with the members of the Court of Policy and College of Electors, many of whom are the largest employers of labour in the colony, and the ordinance is rightly regarded by both with triumph as showing what can be done in an enlightened age by the mutual discussion and liberal treatment of a subject on which their immediate interests have from time to time been considered divergent, if not often incompatible. Looking to the arbitrary treatment of labourers which once prevailed in the British Colonies, and similar instances to which can be found in my notes on foreign colonies, the Government of British Guiana is to be congratulated on having obtained from the planters an expression of opinion so much in accordance with the wishes of the Government of India, and the planters are proud to be able to show that they are working hand in hand with the Government in making the position of the immigrants so desirable that they may expect large additions to the numbers of East Indians who come to, and 
especially of those who remain permanently in, the colony. They are also naturally anxious to show that no trace remains of the abuses or the report of them which led to the appointment of the Immigration Commission of $187 \mathrm{I}-72$. There is a strong opinion prevailing in the colonies of Trinidad and Demerara that the Government of India is unaware of the extent of the immense improvements in the position of the immigrants which have been made in recent years; and considering the absolutely vital importance of the continued, if not increased, importation of East Indian labour, the colonists wish that their relations to their labourers should be fully understood and appreciated by the Government of India. The Government of British Guiana, as well as the employers of labour, are earnestly desirous of showing that every arrangement has been made to render the position of the intending immigrant, both as an indentured labourer and thereafter as a peasant proprietor or independent tradesman, a secure and enviable one, and that his opportunities for social and moral advancement are on a par, if not superior, to that which the native of India of the class from which the cooly is drawn could obtain in any other colony, and certainly far better than he could hope to get in his own country. With these wishes prevailing, it would, I am sure, be a serious mistake to minimize the importance of or throw cold water on any well-considered scheme which has been proposed for the improvement of the status of the immigrant ; and I am afraid that any discouragement of such well-meant attempts would lead to the supposition that the mother-country is not 
sufficiently well acquainted with, or is indifferent to, the best interests of her people. To foster such an idea would be most injurious to the future prospects of East Indians in all colonies. The proposed British Guiana Immigration Ordinance of $\mathrm{I} 89 \mathrm{I}$ is not perfect, and some alterations are necessary; but it is so far an advance on all previous ordinances, and is conceived in so much more liberal a spirit, that I have no hesitation in saying that it should after revision, in the best interests of the immigrants, be adopted not only in Demerara, but also in Trinidad, where the Immigration Ordinance is obsolete and unsuitable. For smaller colonies some further modifications would be necessary. There are many Indian subjects in foreign colonies, yet there is no set of laws concerning them for the guidance of even our own colonies, which can be pointed out as those which the Government of India would desire to see universally adopted.

"At an interview I had with His Excellency the Governor of Guadeloupe, I spoke strongly as to the great difference in the laws framed for the treatment of Indian immigrants in British and foreign colonies, and the Governor was so much impressed that, after a consideration of the terms of this ordinance, a copy of which I showed him, he promised to obtain the consent of the Government of France to its introduction. I was obliged to regretfully admit that it had not been authoritatively approved by the Home Government, and thereby a great opportunity was lost of bettering the condition of the Indian immigrants in Guadeloupe, and thereafter of those in the other French colonies, which could not well have refused to consent to arrangements approved of by 


\section{THE BROAD STONE OF EMPIRE}

one of its own colonies, - at all events opposition to them would have been deprived of much of its force."

In the meantime, Dr. Comins fulfilled his mission practically as Agent of the Government of India in charge of the Department, in the sense I have described, with every facility for inquiry at his disposal, through the machinery of the office and its agents, in the only spirit in which the system can be successfully administered,-a spirit of impartial sympathy with employers and employed. And it is but justice to the planting community to declare that they associated themselves with him in a spirit of frank and loyal co-operation.

It does not lie within my purpose to discuss his report submitted to the Government of India. It had two definite results. It vindicated the immigration system of the colony and the methods of its administration in the following terms:

"The immigration system of this colony has, through many vicissitudes and at times much opposition, and constant improvement and reform, been brought to such a perfection that it now stands as an example to all the world of British faimess, honesty and organization in the beneficial control of a humble and dependent race. Such small inconsistencies with existing regulations as $I$, after much minute and patient investigation and experience of immigration in other colonies, was able to notice, are rare and insignificant, and well within the powers of departmental supervision to rectify."

The other, perhaps the most important, definite result, was the sanction of the Government of India 
to the Ordinance of $189 \mathrm{I}$, with some amendments in detail but no modification of principle.

An indirect result was to show the superiority of the method of investigation into the working of the Immigration system by friendly inquiry over the system of inquisition by commission,-Royal or Special. As regards the general condition of the East Indian population born in the colony, compared with the condition of his class in their country of origin I give an illumining extract from the report.

"No one who knows the Indian cooly well can fail to be struck by the great difference between the cooly in India and his children born in the Colony. Whatever be the cause, whether change of climate, better food, easy times, more responsible duties or position, the influence of travel, or freedom from the narrowness of caste prejudice, the result is very apparent. The children born in the Colony of Indian parents revert to a higher type of civilisation, and in appearance, manners and intelligence are so much superior to their parents that it is difficult to believe they belong to the same family. The boys and young men are stronger and better looking, and are able to turn their hand to anything at a moment's notice, with a smartness and knowledge of the world which would vastly astonish their grandparents in India; while the girls and young women have a beauty and refinement rarely seen in public in India, many having all the appearance of good birth and breeding usually associated only with families of the best blood. The daughters of men who do not require them to work, they lead a happy 
life, free from the care and toil which aged their mothers before they reached their prime."

Opportunity was taken of Dr. Comins's visit to prepare a memorandum illustrating the economic position of the East Indian immigrants at the time as compared with the admitted conditions of destitution which had been the motive of their migration. It was submitted to the Government of India with Dr. Comins's Report. The principal facts and figures may be recorded.

On December $31 \mathrm{st}, 1890$, the adult Indian immigrant population was estimated at about 80,000 . Deducting from these the immigrants under indenture, there remained a population of free adult immigrants consisting of about 42,000 males and 22,000 females.

The Indian is a born money-lender, and has in every colony to which he has migrated shown an extraordinary aptitude and intelligence in putting out his savings at a high rate of interest. His ideas of reasonable interest are based on the traditional custom of lending a bag of rice for sowing, and receiving a return of two bags at the time of harvest. Of his private investments in this way there was of course no means of making even an approximate estimate. The total amount at credit of the Indian immigrants in the Government and Post Office savings banks on December 3 Ist, I890, was $\mathscr{E}_{117,8} 8_{2}$ ils. $8 \mathrm{~d}$. They owned property in land and houses in the City of Georgetown and in the Town of New Amsterdam valued at $£ 25,86 \mathrm{I}$, on which taxes were payable to the amount of $£_{516}$ i4s. In villages, twenty-three 
in number, they owned houses and lots valued at $£ 20,508$. The extraordinary facilities offered in the colony for the lease or purchase of Crown lands had placed it within the reach of very small capitalists to acquire extensive tracts. Crown lands were exposed for sale at an upset price of $4 \mathrm{~s}$. $2 \mathrm{~d}$. an acre, or leased at a yearly rental of $2 \frac{1}{2} \mathrm{~d}$. an acre. Returns compiled by the Registrar-General, though admittedly imperfect, showed the registration of 4I 5 titles to freehold land, exclusive of property held in towns and villages, valued at nearly $£ 25$,000.

It was impossible to give accurate information as to the number and value of cattle, sheep, etc., owned by Indian immigrants at this date, but a return obtained by the Immigration Commissioners in I $87 \mathrm{I}$ gave the value of stock owned by them as exceeding \&1 30,000 . Taking the increased area of lands in rural districts held in freehold by them as some indication, it is probable that this amount was much below the value in $189 \mathrm{I}$.

In the meantime, the immigrant had not been unmindful of friends at home. He had annually remitted money to India. In I 88 I he had remitted, through the colonial Treasury, drafts amounting to about $£ 475$; in 1890 he remitted Post Office Orders of the value of nearly $£_{5200}$.

At the same time, the repatriated immigrants had not returned empty handed. Exclusive of what was carried about the person, the registered value of money and jewellery taken, or deposited for return on arrival, in 1854 , - the first recorded year -was about $£ 4000$; in 1890 it amounted to over $£ 28,000$. 


\section{THE BROAD STONE OF EMPIRE}

These facts and figures furnish an interesting illustration of the economy and thrift of the East Indian immigrant. For the average rate of wages for labour in the fields and factories of the sugar industry, to which he had been almost exclusively indentured on his first arrival, varied from one to four shillings a day.

It will be appropriate here to take a survey of the evolution of the colony of British Guiana and of the forces that have controlled it. It reveals a process of singular interest in the development of the resources of the tropics by a population curiously small in proportion to the area of activity and the diversity of resources.

The area of territory, as has been stated, is nearly equal to the area of the United Kingdom. From the point of view of economic geography it presents three belts: a flat coast belt of alluvial soil unsurpassed in fertility and suited for many varieties of tropical agriculture; a belt of hills and plains rich in forest and mineral products; and an elevated savannah adapted to the agricultural and pastoral industries of a temperate climate.

The natural resources of these three belts are conveniently classified under the heads of agricultural, forest, mineral, and power resources. The agricultural resources include most of the articles of tropical produce that enter into the consumption of our households, such as sugar, coffee, cocoa, bananas, citrous and other fruits, and rice, while in respect of raw materials, the colony offers a field of exceptional promise for the operations of the British Cotton Growers' Association. Its 
forest resources are practically unlimited, and include timbers that range from the hardest, such as greenheart, - - timber largely employed in the construction of the Manchester Canal-to wood that has been found the most suitable yet discovered for the manufacture of match-boxes. A variety of areas seem ideally suited for the cultivation of a variety of rubber-yielding trees. Of its mineral resources it is enough to say that they include the most precious of metals and minerals, - gold and diamonds.

It has been shown that the estimated population, exclusive of aboriginal Indians, does not exceed 300,000 , while the estimated male population over fifteen years of age does not exceed I 20,000. The evolution of this small population is of singular interest, for it includes the three main types of the human race. The Mongolian race is represented by the aboriginal Red Indians of the American Continent and the yellow Chinese of Asia; the Caucasian by the white European and the brown East Indian; and the negro by blacks of African origin. Of the American Indians, numbering some thousands, no reliable estimate can be made. Apart from these the population, broadly grouped, is composed of about I 5,000 Europeans, 35,000 European descendants of mixed race, I 30,000 Asiatics, and 1 20,000 Africans. It is remarkable how in the development of the resources of British Guiana each of these elements is finding an appropriate place.

The European was the original founder of the enterprise and remains the predominant partner. He introduced capital and organised industry. In reclaiming, draining, and empoldering the alluvial 


\section{THE BROAD STONE OF EMPIRE}

belt; in the cultivation and manufacture of sugar and allied products he brought to bear an educated intelligence which has applied to practical uses in the field and in the factory all the secrets that science has wrested from nature. It was the European who introduced and trained the African and Asiatic communities, and at the appointed time set up a form of government recognising the equal rights of every civilised man, and absolute equality before the law for all without distinction of origin. By a singular destiny the African, who had been introduced to replace the original Red Indian, was to be mainly instrumental in finding an appropriate place for him in the new system. With the expansion of industry into districts only accessible by waterways obstructed by series after series of falls and cataracts, the knowledge of the Red Indians made them absolutely indispensable as boatmen. It was mainly the mineral industry that gave an impetus to this expansion.

In a lecture delivered before the West Indian Committee in 1907, Professor Harrison pointed out that the successful exploitation of gold and diamonds must be regarded as mainly due to the African section of the community. "Negroes," he says, "first proved the existence of payable deposits of both gold and diamonds; they have to a considerable extent superintended their development, and they have expended their energies and not infrequently their small capital in working them."

Meanwhile the Asiatic community were making a remarkable contribution to the development of the resources of the colony. A consequence of the 
introduction of Asiatic immigration was the introduction of rice, the staple of Asiatic diet, which before long became a staple of colonial diet. For many years all the rice consumed in British Guiana was imported, but in time the Indian immigrants released from their indenture in parts of the colony which they knew, from their home experience, to be adapted to rice culture, of their independent initiative, encouraged by a few planters, started and established the rice industry. The colony is now not only self-supporting in respect of this commodity, but between 1901 and 1906 the exports rose from $160 \mathrm{lbs}$. to $3,500,000 \mathrm{lbs}$, while the area under cultivation increased from 6,000 acres to 30,000 acres.

It remains to say a word on the power resources of British Guiana. Nothing has yet been done to develope the power resources latent in the falls and cataracts that extend for miles along the course of many of the great rivers that traverse it, and by which alone access can be gained to the mineral resources of the interior. But there can be no doubt that the development of electrical energy from these falls and cataracts would do more than anything to ensure the rapid development of the forest and mineral resources of the interior. It would to a considerable extent solve the problem of the labour supply, upon which the future development of the colony depends.

The development of these resources and the expansion of industry into the interior by increased facility of transport present a vast area for the activity of Asiatic and African labour, encouraged 


\section{THE BROAD STONE OF EMPIRE}

by European capital and organised by European intelligence.

\section{MAURITIUS}

Ever since the abolition of slavery the substitution of Asiatic for African labour, with its consequences, has dominated the political history of Mauritius. In appreciating the policy of protected Asiatic immigration, it must be constantly borne in mind that in view of the refusal of the African population to carry on the elementary labours of agriculture on the estates, there was practically no alternative but the abandonment of the island, which would certainly have reverted to France. It is possible that, at a time when the British Government was seriously contemplating the secession by consent of her colonies, such an alternative might have been admitted; but it is certain that, in the revival of colonial enterprise and the struggle for the control of the tropics, we should, notwithstanding the modern trade-route of the Suez Canal, have found our imperial interests hardly less seriously compromised by such an action at the close of the nineteenth century than they were at the close of the eighteenth. Coincidently the same policy, controlled by the same methods, saved our West Indian Islands, which but for the migration from India, must have gone out of cultivation. They would, beyond all doubt, have passed into the hands of the United States, and carried with them undisputed supremacy in the Caribbean Sea.

The system of immigration in Mauritius has been subjected to special inquiry on several occasions, 
of which only the principal need be mentioned. Between 1834 and I 839 there were introduced about 24,000 Indian coolies under a free system of engagement for five years. In 1839 , when this system was first legalised by ordinance, it was immediately suspended in consequence of an agitation in Parliament; but in 1842 , after an inquiry undertaken by the Government of India, immigration under contract was resumed. In 1874 the system was again the subject of inquiry by a Royal Commission, and their report was the basis of the organic labour law of the colony. I need add nothing to what has already been said on the subject of this Commission.

In March, 1893, the Government of India, on deciding to depute an officer to the French colony of Réunion to inquire into the condition of the Indian coolies engaged there under the Labour Laws, directed that he should visit the adjacent island of Mauritius, and ascertain such facts regarding the condition of the Indian population there as could be collected without unduly prolonging the time required for the Réunion inquiry. The object was twofold. First, to obtain a useful standpoint of comparison with Réunion, and secondly, to carry out one of these personal inspections by an Indian Government official which the Colonial Office had accepted as a valuable guarantee for the maintenance of a satisfactory standard in the treatment of Indian immigrants into British colonies.

There was, however, no special demand for the visit to Mauritius either by the Indian Government on account of ill-treatment of the immigrants or other scandals, or for the reasons that had led to 


\section{THE BROAD STONE OF EMPIRE}

Dr. Comins's visit to the West Indies. The purpose was merely to ascertain that matters were progressing satisfactorily.

The following tables show the constituent elements of the population of Mauritius in 1830 , before the abolition of slavery, and in rgor. The figures for I 830 are, of course, approximate; those for I90I are taken from the census returns.

POPULATION OF MAURITIUS EXCLUSIVE OF MILITARY AND SHIPPING I830 APPROXIMATE.

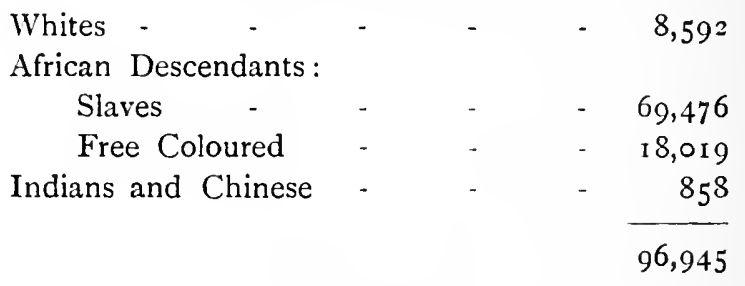

CENSUS igor.

\begin{tabular}{|c|c|c|c|c|c|}
\hline \multicolumn{3}{|c|}{$\begin{array}{l}\text { Europeans, white, mixed } \\
\text { and coloured }\end{array}$} & $\begin{array}{l}\text { Male. } \\
53,038\end{array}$ & Female. & $\begin{array}{l}\text { Total. } \\
\text { I } 08,4 r_{5}\end{array}$ \\
\hline Africans & - & . & $33^{2}$ & 100 & $43^{2}$ \\
\hline Indians - & - & & 144,957 & I 16,023 & 260,980 \\
\hline hinese & - & - & $3,45 \mathrm{I}$ & $5^{8}$ & $3,5 \circ 9$ \\
\hline & & & 201,778 & I 7 I, $55^{8}$ & 373 \\
\hline
\end{tabular}

A comparison of these returns shows a most remarkable racial development to which I shall refer later.

It must be added that while the population of British Guiana at the period of the visit of the Commissioners did not exceed 2.5 per square mile, the population of Mauritius at the time of Sir Muir Mackenzie's visit exceeded 500 to the square mile. 
The conditions that invited consideration differed therefore materially in the two colonies, and consequently the first question that excited Sir Muir Mackenzie's attention was whether the time had come to arrest further immigration altogether. $\mathrm{His}$ conclusions showed that this economic question is closely connected with the question of the civic position of the Indian immigrants. After an exhaustive inquiry and an elaborate analysis of the evidence, he summed up his conclusions as follows:

"From what has been recorded it will be gathered that despite the existence of defects such as will probably present themselves in any system of administration which might be subjected to special critical inquiry, the Indian coolie in Mauritius enjoys a very substantial degree of prosperity. This is demonstrated by the numerical development of the Indian population and the amount of their accumulations in cash and land. It has also been shown that notwithstanding some disadvantage in political status and representation, the Indian enjoys on the whole equal justice and undisturbed freedom after the completion of his first indenture. The above conclusions, supported by such evidence as I could collect in the course of my inquiry, are fully confirmed by the impressions made upon me by what I saw and heard. The general appearance of the coolies was most satisfactory. In the fields the gangs showed cheerfulness and activity, and the men appeared hale and vigorous. The children and wives, as seen mostly in the camps, seemed generally well-nourished, well-clothed, and, for their class, clean. On the roads, especially on Sundays and 
holidays, Indians are to be seen in large numbers in the busy little railway stations and trains, clad in bright colours, the women well supplied with ornaments. The Indians also testified to their happiness by their independent, while civil demeanour, and their cheerful and ready answers when addressed. I feel no doubt that, considering the class from which they are derived, the immigrants settled in Mauritius, and much more their offspring, have made a decided advance in civilisation and material comfort. But it would be folly to ignore the dangers ahead. The first and chief of them is that of overmultiplication and the consequent glut of the labour market. It is impossible not to look forward to a time when India herself shall supply the whole of the sugar required for consumption there, instead of importing it in large quantities from Mauritius. Taking all the facts into consideration, there is ground for predicting an increasing development of other industries besides sugar-making in Mauritius. This, however, will not diminish, but on the contrary will serve to maintain the demand for labour for the supply of which the Colony will always depend chiefly on its Indian inhabitants. I must, however, repeat the caution that, attractive as Mauritius may be as a field for emigration from India, the time is gone by when anything like stimulation should be extended to it. The other danger, but much more remote, is political. The jealousy which exists between the Creole and the Indian population is too patent to be dismissed sub silentio. Under the existing form of Government this jealousy has been held in check, not always without difficulty, as 
shown by the records of the Colonial and India Offices, as well as of the Mauritius and Indian Governments. If the form of Government is to be popularised, the external checks will be weakened, and the interests of the Indian must, therefore, in such an event, be carefully safeguarded. It must not be supposed that I allude to these dangers with an ill-judged carelessness of stirring passions now happily slumbering. It is because I am acutely sensible of the nicety of adjustment on which the stability of the political balance in Mauritius depends that I venture to sound a note of warning. At present the relations between the Indian and nonIndian sections of the population are peculiarly cordial and satisfactory. No doubt this is due principally to long experience by all classes of just, benevolent, and impartial administration. But the increasing harmony has been quickened into active kindliness by the pressure of common calamity."

These conclusions prompted the following recommendations on the political status of Indians :

"I venture to think that the Government of Mauritius might with great propriety be invited to consider and frame proposals for the better representation of Indian interests upon the Councils, and to secure that in any extension of the franchise, the rights of Indians shall be considered no less liberally than those of the Creoles. For the present the simplest way of getting Indians represented on the Council would be for the Governor to nominate some of their number. It would also be easy to make them more alive to their rights under the existing franchise. But knowledge of this sort is 


\section{$35^{8}$ THE BROAD STONE OF EMPIRE}

sure to come with time; and having regard to the influences likely to be brought to bear upon the average Indian voter, and the feebleness of his power of resistance against them, I feel in no hurry to see any encouragement of canvassing among them. Another feature of the Mauritius system of administration is the entrusting of the administration of some of the principal departments to Committees, Councils, or Boards, the members of which are nominated, I believe, by the Governor in Executive Council. ${ }^{1}$ On these Councils, again, the Indian is really but little, and ought to be better represented, especially upon the Council of Education."

The conclusions of the Government of India may be briefly summarised. On the general question of the welfare of the immigrant population, they wrote: "We are much gratified to find that the Report amply confirms our previous information as to the satisfactory condition of the Indian population in Mauritius, and as to the substantial degree of prosperity enjoyed by the vast majority of immigrants whether free or living under indenture."

On the question of exercising caution in the future encouragement of immigration, they wrote: "We agree with the Governments of Madras and Bengal that no special measures are at present required on our part to discourage or restrict emigration from India to Mauritius. As is remarked in the Report, the tendency is for the planter to depend more and more on the supply of labour existing in the Island, and for emigration from India to automatically fall off."

${ }^{1}$ They are nominated by the Governor. 
On the recommendations of the report in respect of civic privileges the Government of India desired to make no observations for the reason that they dealt with the civil constitution of the colony.

The general recommendations of the Government of India, on the defects alluded to by Sir Muir Mackenzie, may be grouped under four heads; the organisation of the Immigration Department; the civil status of the immigrant; sanitation; modifications of the labour and vagrancy laws in respect of certain offences which had led to numerous convictions. It is hardly necessary to enter into a detailed consideration of the recommendations of the Government made under the first two heads. They lay within the province of the Governor and were easily carried out. The question of sanitation involved large issues which are fully dealt with in my chapter on Health. The modification of the labour and vagrancy laws required legislative enactments; and these had to be submitted to the India Office and the Government of India. The draft Ordinances I caused to be prepared were approved and welcomed by the Government of India, but their preparation required much care and consideration, and transmission to and fro between the colony, the Colonial Office, the India Office and the Government of India took time. I was unable to carry them through the Legislature before I left Mauritius. I understand that they have since become law.

It remains for me only to deal with Sir Muir Mackenzie's proposals on the civic privileges of the Indian population on which the Government of 
India made no recommendation. As they involve a question which has since been much agitated, I may speak of them more fully. They were entirely in accord with my own views, but I was aware that they were not in accord with the views of the nonIndian community. I satisfied myself, however, that I was assured of the support of Mr. Chamberlain, and, on opportunities occurring, I nominated, subject to the approval of the Secretary of State, an Indian gentleman of acknowledged position in the medical profession, Dr. Nalletamby, for a seat in the Council of Government; and I appointed Mr. M. Atchia, a merchant, to be member of a board of Commissioners for a Township. Few episodes in my long colonial career have been more painful to me than the resistance offered to these appointments. It was contended that they were an insult to the Mauritian community. I do not desire to dwell on it, but it is well at least to put on record Mr. Chamberlain's views on a subject of such widereaching importance. An extract from my despatch on the subject and Mr. Chamberlain's reply need no comment :

Government House, Mauritius, October I4, I90I.

"I can find nothing in the Constitution of the Colony or in the views of Her Majesty's Government, at the time the present Constitution was granted, or in the action of the Governor who is mainly responsible for it, to justify such a contention.

In the year 1884 Sir John Pope Hennessy appointed a Commission "for the purpose of en- 
quiring and reporting what electoral divisions should be formed in the island for the election of six members of the Council of Government; and what qualifications should be held necessary to entitle persons to vote at such elections."

This Commission was appointed by proclamation in the Government Gazette of September Ioth, 1884. It consisted of thirty-two members, of whom no less than four were of Asiatic origin. It will hardly, I presume, be urged that it was intended to exclude from the privileges of the contemplated constitution, the representatives of a Community, whose right to vote in its design and details was so fully recognised. Of the four members of the Commission of Asiatic origin, two, Affan-Tank-Wen, and Goolam Mamode Ajam, spoke the creole patois.

The Report of the Committee was transmitted to the Secretary of State, the Earl of Derby, who, in his despatch in reply, No. 143, of May 4th, I885, paragraph 5 said :

"In order to give a fair share in the representation to the middle class, and especially to the large class of Indians who, as the purchasers or mortgagees of land, have acquired a permanent interest in the well-being of the Colony, it appears to me that a more liberal franchise is required than that which has been advocated by the Commission;" and in the 8th paragraph of his despatch Lord Derby said: "As regards an educational test, I consider that the circumstances of Mauritius make it desirable that persons unable to read and write should not be admitted to the franchise; but it would not, in my opinion, be just to the Indian population to 


\section{THE BROAD STONE OF EMPIRE}

require them to be able to read or write in any other than their own language as a condition of being registered as voters."

In his speech opening the first Session of the Council of Government under the New Constitution, on April I9th, I886, Sir John Pope Hennessy said:

"I should certainly have been glad to have seen a larger proportion of Indians on our Electoral Roll. Looking to their many good qualities, we must encourage the large numbers of those who possess the required qualifications to vote, and who are permanently associated with the Colony, to enter into our political life. As far as I can constitutionally act in that direction I have done so by appointing a leading member of the Indian community to one of the nominee seats in the Council."

I can find no record of any objection to this nomination in the declaration that accompanied it, as being a defiance of the Mauritian community; and yet it is certain that the number of Indians who now hold large and permanent interests in the Colony has enormously increased during the last fifteen years.

On the general question then of the right of Indians to representation in the Council of Government, and a fortior i on Town Boards and Committees, I shall add nothing to what I have said.

... It is important to bear in mind that the object of giving to the Indian community a fair representation on the Council or on Town Boards or Committees is two-fold: to enable the Council or 
Board or Committee to learn the real wishes of the community through their representative; and to enlist on behalf of the measures adopted the influence of their representative over the Indian community. There are circumstances connected with the Town of Beau Bassin and Rose Hill, which illustrate the advantages likely to be derived from the exercise of such influence. Measures taken against plague in this district have caused considerable trouble, more, indeed, than in most other districts, and my experience in this Colony convinces me of the wisdom of the decision adopted last year by the Government of India, who have laid it down, in accordance with the recommendations of the Plague Commission, that the first principle of all plague measures should be that:

"Except in extraordinary circumstances compulsion should be eschewed, and that the efforts of Government should be directed to convince the people of the utility of particular methods, and to induce them to carry them out, not by force, but by the exercise of their own free will."

Having thus submitted to you the reasons which have guided me in the nomination of Mr. Atchia to be a member of the Board of Commissioners of Beau Bassin and Rose Hill, I may sum up my views in the following propositions:

I. That it is, and has been, the policy of His Majesty's Government from the establishment of the present constitution of the Colony to recognise the claim of His Majesty's Indian subjects in Mauritius, possessed of the necessary qualifications and permanently associated with the Colony, to enjoy 


\section{${ }_{364}$ THE BROAD STONE OF EMPIRE}

equal rights of representation, in the Council of Government or on Boards or Committees, with the rest of the community.

2. That, however desirable it may be that representatives of the Indian Community should be able to speak English or French, more or less correctly or elegantly, no such educational test is required as a sine quâx non, to justify the election or nomination of an Indian member, provided that he has the qualifications necessary to enable him to speak on behalf of and to influence the Community he is chosen to represent."

$\mathrm{Mr}$. Chamberlain's reply was as follows :

Downing Street,

December 4th, I90I.

Sir,

I have the honour to acknowledge the receipt of your despatches, Nos. $35^{8}$ and 392, of the 14 th and 2 ist October on the subject of the appointments of Dr. M. F. X. Nalletamby to be an unofficial member of the Council of Government and of $\mathrm{Mr}$. M. Atchia to be a member of the Board of Commissioners for Beau Bassin and Rose Hill.

Your action in making these two appointments meets with my entire approval. The selection of members of the Indian community as representatives of the people on the public bodies of the Colony is in accordance with the principles laid down from the outset in connection with the introduction of a representative element in the Constitution of Mauritius. I can conceive no reason why a class of $\mathrm{His}$ Majesty's subjects which constitutes the majority of 
the population of the Island should be deprived of a voice in public affairs, solely on account of an Asiatic origin, and I cannot therefore admit the contention that the Indians have no right to be represented in the Council.

That this Indian Community is beginning to take that share in public life which its important interests in the Colony render desirable is, in my opinion, a matter for congratulation.

I have, etc.,

J. Chamberlain.

It remains for me only to sum up the results of immigration in Mauritius in the social development of a population combining elements of European, African, and Asiatic origin.

We have seen that the population in I90I was composed of Io8,4I 5 Europeans, white, mixed, and coloured, 432 Africans, 260,9So Indians, and 3,509 Chinese. The population classed as Europeans includes all persons with European blood in their veins, and with the 432 persons returned as Africans is known locally as the general community.

The members of this community of pure European descent cannot exceed 5000. The English element is very small, and may be said to stand in much the same social relation to the French element as the corresponding elements of Canadian society. The predominant influence is that of the families "gifted," to quote a phrase of our present gracious Sovereign, after his visit to the Colony in I90I, "with the charming characteristics of old France." They enjoy the respect still entertained in England, and 
even in republican France, for a small circle of society where the traditions of birth are associated with personal virtues finding expression in the sentiment noblesse oblige. They cling to each other "in either fortune" with a brave tenacity of attachment. Their ladies represent the grandes dames of European society. But their influence is purely personal, as is the influence, of a different order, of the English representatives of English capital and enterprise. Otherwise there is no distinction of origin. There are, of course, social gradations as there are in Europe, and in the colonies that claim to be exclusively reserved for the use of the white man. But the State recognises no aristocracy but that of office; society none but that of merit and success. High office in the administration, the dignity of the Bench, the honours and emoluments of the learned professions, the influence of landed property are open to all. The general community supply the staff of the government offices, including the Public Works, Railway and Harbour Departments, as well as the staff of all private enterprises except those undertaken by the Indian community. They also do practically all the skilled artisan and mechanical work of the colony. The small number of persons returned as Africans, which the Registrar thinks may be somewhat under-rated, includes an intrepid and skilful body of men engaged in the fishing and coasting trades. In the evolution of the general community the principal forces at work have been education and the Christian religion. The operation of these forces will be fully dealt with in separate chapters.

While the direct object of immigration from India 
was the supply of unskilled manual labour, it has had far-reaching consequences. The frugal industry of the Indian labourers, when they have ceased to enter into engagements by written contract under the labour law, has gradually enabled them to acquire a vast number of small holdings, to the great advantage of the colony. They have thus given a value to and kept in cultivation an extensive area of land which must otherwise have been abandoned; their canes have been a profitable source of supply to the sugar-mills of the large estates; and the cultivation of their small holdings has left them ample time to work as gardeners, carters, carriers, hawkers, and pedlars. In this way they have acquired almost a monopoly of the carrying business, and this has served as a link connecting them with agriculture on one side and trade on another. For in the meantime a consequence of the Asiatic immigration was the introduction of rice as the staple diet of the whole colony, while coincidently the competition of beet-root sugar in Europe and other causes made India the chief market for Mauritius sugar. Thus, the bulk of the export and import trade, including nearly all the commodities that enter into the constant consumption and use of the population, has been transferred from Europe to Asia, and has fallen into the hands of the Indian traders, mostly representatives of wealthy Bombay firms. They have naturally helped to find employment for their countrymen in the carrying and hawking trade as distributors of their commerce.

On the subject of the Indian community I may add that between the traders who have acquired 


\section{THE BROAD STONE OF EMPIRE}

estates and the proprietors of small holdings, it owns more than one-third of the whole cultivated area of the colony, nearly all of which would have been abandoned but for the enterprise and industry of these men.

The Chinese are a peculiar people and occupy a peculiar position in Mauritius, as elsewhere. Their activity is in the main engaged in the retail provision and liquor trades, a subject to which I shall have occasion to refer more fully. They have served a useful purpose, and have always loyally submitted themselves to the regulations and wishes of the government. On several occasions during my administrative career the police have reported that the Chinese community were giving trouble. I have always been able to arrest it by sending for the headman and saying: "Chinaman too much plenty bobbery make; you get topside that bobbery." On one occasion the headman told me he would do his best, though it was as much as his life was worth. It was during an epidemic of plague in Mauritius. But he got "topside."

The Chinese perfectly understand that Mauritius affords a very limited area for their transactions, and that if they increased and multiplied, competition among themselves would reduce the small margin of profit with which they are satisfied below a living wage. With rare exceptions, therefore, they never bring their woman-kind with them, and have no intention whatever of becoming permanent residents. They work unceasingly to enable them to return home as soon as possible with what is to them a sufficient fortune. By arrangement 
among themselves, - an arrangement with which the government has nothing to do-about ten per cent. repatriate themselves every year, and make room for others. This will explain the small percentage of females in the census return.

I traced in a previous chapter the evolution of the political constitution of Mauritius, and I have now shown how admission has been secured for representatives of the Indian community into the Council of Government as well as into the administrative system of local government. I believe that so far as regards the civic rights of the Indian community what has been secured for them is all that Sir Muir Mackenzie desired. They are not keen politicians and are generally satisfied to leave themselves in the hands of the Government rather than seek admission to the Council of Government by election. But the adjustment of the supply of labour to the demand is a question of constant anxiety in Mauritius, as it is throughout the civilised world. During my tenure of office as Governor it was disturbed by extraordinary fluctuations for reasons which will be dealt with in another chapter. A departmental Committee appointed by Lord Crewe in 1909, with Lord Sanderson as Chairman, to inquire into the general question of emigration from British India, has reported that the present population of Mauritius is adequate to the requirements of the colony. 


\section{CHAPTER XI}

THE COLOURED RACES

THE international struggle for the control of the tropics has confronted all the Powers engaged in it with two historical developments admirably described by Mr. Edgar Gardner Murphy in a recent work on The Basis of Ascendancy. Mr. Murphy is concerned mainly with the relations of North and South in the United States arising out of these developments, but the problem he states is inseparable from the association of Europeans, Africans, and Asiatics in the beneficial occupation of the tropics.

"First, there is the tendency towards inclusion, the movement of empire, the gradual incorporation of the weaker races and groups within the administrative federation of the stronger. Secondly, there is the movement of democracy, the tendency toward the broader distribution of the units of control. The stronger peoples are drawing into closer and closer relations with the weaker, and yet the terms under which these relations are established and expressed are invariably tinged and coloured by the democratic assumptions to which modern society is increasingly committed. The movement of empire is indeed 
modifying certain of our older notions of democracy, correcting some of our doctrinaire conceptions as to the natural equality of men; but the movement of democracy is modifying even more deeply some of our older notions of empire, is correcting the legal presumptions of inequality, is enforcing the conception of the equality of rights before the law, is impressing the fact of the social responsibility of the strong, is discouraging and slowly arresting the destructive policies of exploitation, and everywhere commending the redemptive and constructive policies of equity, order and education. It is no easy problem-this problem of the strong living with the weak (as the strong have resolved to do) and yet so living with them as to keep faith with those profounder interests of the weak which are also the interests of the strong,- - so living as to assure peace without inflicting desolation, as to preserve order without defeating justice, as to upbuild a State which will express the life of its higher groups without enfeebling or destroying that waiting manhood of weaker peoples which itself craves and deserves expression."

Reason, the history of the past, and the experience of the present conflict for the control of the tropics have suggested only two possible methods of solving the problem. They present the alternative, "Where two social groups - a stronger and a weaker-find themselves in inevitable conflict upon the same soil, what elementary principles shall ultimately determine the policy of the State? Shall the principle of its policy be repressive or constructive?" The choice of a policy must depend on its ultimate aim. 


\section{THE BROAD STONE OF EMPIRE}

In this case the ultimate aim is a maximum of productivity in the development of the resources of the tropics through the agency of the two groups. From the point of view of the general motives of humanity, John Stuart Mill reasons thus:

"Among the secondary causes which determine the productiveness of productive agents, the most important is Security. By security I mean the completeness of the protection which society affords to its members.... The efficiency of industry may be expected to be great, in proportion as the fruits of industry are insured to the person exerting it; and all social arrangements are conducive to useful exertion according as they provide that the reward of every one for his labour shall be proportioned as much as possible to the benefit which it produces.... All laws and usages which favor one class or sort of persons to the disadvantage of others; which chain up the efforts of any part of the community in pursuit of their own good, or stand between those efforts and their natural fruits are (independently of all other grounds of condemnation) violations of the fundamental principles of economical policy; tending to make the aggregate productive powers of the community productive in a less degree than they would otherwise be. . .."

The argument of reason against a policy of repression as an instrument of security is abundantly confirmed by history. I have traced in an earlier chapter the main lines of a conflict, coeval with European civilisation, between a class by 
whose labour the natural resources of the earth were developed and a class by whose intelligence the fruits of that labour were appropriated. I have shown that the conflict was maintained for centuries by a policy of repression exercised by the tyranny of the State supported by the tyranny of the Church. And I have illustrated the operation in the United Kingdom of principles that ended by substituting for a policy of repression a constructive policy of equal opportunity, education, and order, as the only possible guarantee of national security. The new policy suggested by reason was confirmed by the experience of history which had established two facts; first, that labour and freedom are indivisible, and secondly, that the social class that develops the material resources of a territory cannot permanently be excluded from a share in the administration of the developed area. The question that now concerns me is whether the constructive policy that has established security for the co-operation of social groups in the United Kingdom is to be prolonged into territories where the social groups representing capital and labour are divided by differences of colour; or whether in such territories a policy of repression is to be revived and substituted for the national constructive policy.

Let us take counsel of history from the earliest days of modern civilisation. The Roman Empire was created and upheld by a policy of territorial expansion embodied in the maxim, Parcere subjectis et debellare superbos, which was freely interpreted to mean, Slaughter all who have courage to resist and make slaves of the rest. It was acted on to the 


\section{THE BROAD STONE OF EMPIRE}

letter and spirit. Did it save Rome from the Barbarians, including the Anglo-Saxon race, against whom it was exercised? When the Pagan Roman Empire was almost strictly conterminous with the then known world it was determined to maintain its integrity by a policy of repression expressed in the formula Christianos ad leones. Did that exterminate Christianity? When the Holy Roman Empire determined to establish one Christian Church, the doctrines of which should be fixed and promulgated by one infallible authority, did the policy of the Inquisition repress the Reformation? Men died at the stake, were broken on the wheel, perished in exile, but Protestantism survived to retaliate by the same methods, until the policy of compulsory obedience to a State Church gave way to a policy of complete religious toleration, the bond of union to the State being the common interest of all in the security of their religious liberties. In 1675 the lower classes in Britanny revolted at the imposition of a new tax, and Madame de Sévigné in a letter to her daughter described how the disturbance was put down: "Voulez vous savoir des nouvelles de Rennes? On a fait une taxe de cent mille écus sur le bourgeois; et si on ne trouve point cette somme dans vingtquatre heures, ella sera doublée et exigible par les soldats. On a chassé et banni toute une grande rue et défendu de les recueillir sous peine de la vie; de sorte qu'on voyait tous ces misérables, vieillards, femmes accouchées, enfans, errer en pleurs au sortir de cette ville sans savoir où aller. On roua avanthier un violon, qui avait commencé la danse et la 
pillerie du papier timbré; il a été écartelé après sa mort, et ses quatre quartiers exposés aux quatre coins de la ville. On a pris soixante bourgeois, et on commence demain les punitions. Cette province est un bel exemple pour les autres, et surtout de respecter les gouverneurs et les gouvernantes, et de ne point jeter de pierres dans leur jardin."

Did this policy of repression save "les gouverneurs et les gouvernantes" from the retaliatory terrors of the French Revolution?

I have dealt at length with the constructive policy which in England saved the governing class from the fate of "les gouverneurs et les gouvernantes," substituted reform for revolution and united the forces of land, capital, and labour in a common interest in the security of a constitutional system in which they had a common share.

But it is argued that there is no analogy between the relations of capital and labour in the United Kingdom and in the Crown colonies where as a rule capital is white and labour coloured. Let me point out, in the first place, that the reforms which opened Parliament to the people were followed by the removal of disabilities from a race whose history has a very close analogy to the history of the relations between the white and coloured races of the world.

Lord Beaconsfield's picturesque rhetoric in describing the attempts made to extirpate the Jews by the most considerable means that man could command through the longest period of recorded time, has already been quoted. There is a curious analogy in the cases. If, in accordance 


\section{THE BROAD STONE OF EMPIRE}

with the sentiment of the time, it has been the modern policy of the white man to resort to degrading customs and debasing laws rather than physical torture and massacre, the unwritten law of lynching in America is being constantly applied to the coloured population with almost incredible ingenuity of malice. A year or two ago an untried offender was placed on a pile of cord-wood, both being saturated with kerosene oil. "A match was touched to him," and not only was the conflagration watched with shouts of joy, but within a few hours thousands of post-card photographs were being sold in the streets. While I am correcting these pages for the press, on April I3th, I910, a case is reported from Mississippi. A negro prisoner was mortally wounded in what was described as a "battle" with the gaolers. A crowd of two thousand people, which had gathered with marvellous rapidity after the first shot was heard, then rushed into the building, seized the dying prisoner, and carried him out. They then passed a rope round his neck and strung him up to a telegraphpole. When the man was dead they cut down the body, and, after slitting the throat, saturated the clothes with oil and set fire to them. And these things are done in days when it is declared to be the duty of all coloured races to acknowledge the inherent and permanent superiority of the white man. Nevertheless, deplorable as are such incidents in their nature and frequency, they do not disturb my confidence that the nobler instincts of humanity, which have controlled the destiny of the Jewish race, will in time secure for $\mathrm{His}$ 
Majesty's coloured subjects throughout the Empire a position free from legislative dishonour and disqualification.

President Roosevelt has declared that there is but one safe rule in dealing with black men as with white men,-it is the same rule that must be applied in dealing with rich men and poor men-that is, to treat each man, whatever his colour, his creed, or his social position, with every possible justice, on his real worth as a man. I believe this to be the faith of the people of England.

It is in this faith, the faith that inspired the Queen's Proclamation to India in 1858 , that the Government of the Crown colonies has been administered. The same administrative problems have been found common to every administrative unit, and they have been solved by prolonging into each the activity of the same principles by a variety of methods appropriate to a variety of environment.

In I 850, when a reformed Imperial Parliament had established the principles to be applied to the administrative problems of the day, a writer of distinction, Mr. William R. Greg, declared that of these problems the true and fit relation between employed and employer was one of the most pressing and the most perplexing:

"One uniform, ceaseless, pervading tendency is discernible through modern history, as far, at least, as the Western world is concerned-the tendency towards the equalisation of social conditions. Amid all vicissitudes, and in despite of all reactions, the progress is obvious and the goal constantly in view. A clue is thus obtained to the purposes of 


\section{THE BROAD STONE OF EMPIRE}

Providence-a light which at once irradiates both past and future, which marshals the lessons of experience, which guides out further speculations, and wonderfully clears up the path of practical duty. From the birth of the existing order of things, an irresistible current has set in, which bears on its bosom institutions and hierarchies, principalities and powers, towards the ocean wherein all will be merged and moulded into their destined forms. It is not towards this or that form of republicanism that we are tending-not towards these or those political institutions-not towards this or that special mode of social organisation : these are but the shell and husk of the interior reality;-it is towards an abolition of partial privileges; towards a paring down of inessential differences; towards an equality, not perhaps of wealth, or of mind, or of inherent power, but of social condition, and of individual rights and freedom. The times when men were separated by barriers of rank and circumstance, which made them almost different beings, are withdrawn far into the past: the times when even those divisions which yet remain will dwindle and vanish away are coming rapidly and visibly nearer."

Mr. Greg limits the operation of the tendency towards the equalisation of social conditions to the Western world. The prolongation of its activity has been met by a new barrier of circumstance,the colour bar. The formidable character of this barrier had already, before Mr. Greg wrote, been foreseen by Mr. Herman Merivale, when Professor of Political Economy at Oxford. In discussing the destiny of the native races with which we were being 
brought into contact, he came to the conclusion that the only alternative was extinction or amalgamation. "This I am most anxious to impress upon your minds, because I firmly believe it to be the very keystone, the leading principle, of all sound theory on the subject-that native races must in every instance either perish or be amalgamated with the general population of their country.

"By amalgamation, I mean the union of natives with settlers in the same community as master and servant, as fellow labourers, as fellow citizens, and if possible, as connected by intermarriage. And I mean by it not that eventual and distant process to which some appear to look by which a native community, when educated and civilised, is to be, at some future period, admitted en masse to the full rights of citizenship; but I mean an immediate and an individual process-immediate, if not in act, at least in contemplation. To answer the view which I am anxious to lay before you, each native must be regarded as potentially a citizen, to become such in all respects as soon as possible. To this end, every step in his instruction and management must conduce. It must be the object in framing every law, in making every provision for his support. Nay, the first steps of the actual operation should rather be accelerated than retarded. I mean that, although prudence must be the guide in all cases, it must be a fixed principle that less evil is likely to be done by over haste than by over delay."

This passage contains the first direct suggestion I have found of the native as potential citizen. The theory has been, as I have shown elsewhere, 
accepted as a cardinal principle of Crown colony administration, and the problems that have arisen out of it are the subject of this work. It has been carried into practice with all the insistence claimed by Mr. Merivale. But this does not apply to the social problem of analgamation by intermarriage, which lies outside the area of administrative activity, but which I shall speak of later.

The problem of the colour bar has during the last few years been discussed in America in a literature which has already assumed portentous dimensions, and this discussion, from the point of view of American circumstances, has led to a dangerous generalisation. It confounds the negro of African origin with the coloured races of Asia, and associates all alike under the common denomination of inferior races. In dealing with the question from the point of view of our tropical colonies, I shall illustrate the distinction. It will be convenient for me to deal first with Asia, and illustrate the position by the example of Ceylon. In Ceylon, as in India, the native community generally, apart from the original Veddas, are the descendants of races who had attained a very high degree of civilisation in law, in religion, in literature, and in art. Judged by our standards, the natives of Aryan and Dravidian descent have a beauty of form and a distinction of manner that compare favourably with the physical phenomena of the people of the United Kingdom. But they are the descendants of conquered communities clinging with devotion, I may say with pride and prejudice, to the traditions of their origin. British rule has 
removed from them the yoke of the conqueror, has respected their pride and prejudice, has invited their co-operation in the administrative function of securing their own liberties. At the same time, we endeavour to associate them in the operations of a new civilisation based on the principle of developing the natural resources of their environment for their own benefit. In this work we bring to their aid, as our capital in the partnership, the results of our own experience of the civilisation we advocate; first, in the solution of administrative problems and, generally, in the application to industrial uses of the clue we have found to the operation of the forces of nature. This is our claim to superiority. Nor do we seek an exclusive monopoly in it. We place at their disposal the instrument by which we acquired it,-education in science and method.

I submit the results of our policy as declared by Sir Henry Blake, in a paper read before the Colonial Institute in January, I 908.

"We now come to the four millions of the natives of Ceylon, and on the treatment of these people, and the results obtained, must be the verdict passed of the success or failure of the British administration. Besides the divisions already mentioned of 2,548,000 Sinhalese, including Kandyans, I, I 28,000 Tamils, 250,000 Moormen or Mahomedans and Malays, there are 24,500 Burghers, except in a few instances a mixed race who claim descent from the Dutch remaining in Ceylon after the occupation by the British. They are among the most intelligent portion of the native community, and supply a considerable proportion of the Ceylon bar and 
medical profession, and the Government officers in various departments. Both at the bar and in medicine, Sinhalese, Tamil and Burgher gentlemen have shown attainments that would entitle them to very prominent positions in either profession, even in the keen competition of a London practice. While there are engineering works, oil, cotton, and chemical manuring factories in various places, and excellent textile fabrics hand-woven at Batticaloa and Jaffna, besides silver and brass work executed by hand at Negombo, Kandy and Ratnapura, Ceylon is essentially an agricultural country, and any general improvement in the condition of the people must be brought about by an improvement in agriculture."

The principles which have guided our administration in Ceylon have been prolonged into an area of activity further East in the Federated Malay States. They underlie the recent formation of a Federal Council including the Sultans of Perak, Selangor, Pahang, and Negri Sembilan.

But those who, reasoning on the false analogy of the relations between whites and negroes in America, infer an inherent inferiority of all coloured races and hold that there can be no equality between races of European and non-European descent, the example of Japan ought to convince of their error. It is not too much to say that no people in the world has evolved a higher civilisation on its own original lines, and adapted itself with equal flexibility to a new civilisation adapted to new circumstances. In $186_{3}$ Sir Rutherford Alcock wrote of the old civilisation: "Here in outward form we have feudalism ... in which the 
feudal lord is everything and the lower and labouring class nothing. Yet, what do we see? Peace, plenty, apparent content, and a country more perfectly and carefully cultivated and kept, with more ornamental timber everywhere than can be matched even in England. The laws, so far as we know, are Draconian in their severity and administered unflinchingly by the very simple and most direct process, without the aid of lawyers. ... On the other hand the material prosperity of a population estimated at $30,000,000$ has made a Garden of Eden of this volcanic soil and has grown in wealth by unaided native industry shut out from all intercourse with the rest of the world."

I have taken the year I 868 as marking a stage in the evolution of the British Empire. In an even more definite sense it marked a stage in the evolution of the Empire of Japan. In April, I 868, the year after the accession to the throne of the present Emperor, one of his first official acts of a public nature was to swear solemnly the following memorable oath, known in Japanese history as the Imperial Oath of five articles.

The five articles were as follows:

"I. Deliberative assemblies shall be established, and all measures of government shall be decided by public opinion.

2. All classes, high and low, shall unite in vigorously carrying out the plan of the government.

3. Officials, civil and military, and all the common people shall, as far as possible, be allowed to fulfil their just desires, so that there may not be any discontent among them. 


\section{THE BROAD STONE OF EMPIRE}

4. Uncivilised customs of former times shall be broken through, and everything shall be based upon the just and equitable principles of nature.

5. Knowledge shall be sought for throughout the whole world, so that the welfare of the Empire may be promoted." 1

In less than half a century Japan has adapted itself to the new conditions and has been admitted to equality of rank with the Great Powers of Western Civilisation.

Nor is it likely that the Japanese will long remain the only coloured race admitted to equality of rank with the white man. Intimately associated with the future of Japan, in its influence on the destiny of the human races in the Far East, is the future of China. On some pretext or other, based on the alleged duties of superior towards inferior races, and on the amazing doctrine that the possessions of inferior races are res nullius, every Power in Europe has seized on some part of Chinese territory. And yet the one Englishman who, above all others, can speak with the authority of long and intimate experience, has thus described the Chinese :

"They are [says Sir Robert Hart] well-behaved, law-abiding, intelligent, economical, and industrious; they can learn anything and do anything; they are punctiliously polite, they worship talent, and they believe in right so firmly that they scorn to think it requires to be supported or enforced by might; they delight in literature, and everywhere they have their literary clubs and coteries for learning and 1 Japan in World Politics, by Henry Dyer. 
for discussing each other's essays and verses; they possess and practice an admirable system of ethics, and they are generous, charitable, and fond of good works; they never forget a favour, they make rich return for any kindness, and though they know money will buy service, a man must be more than wealthy to win public esteem and respect; they are practical, teachable, and wonderfully gifted with common sense; they are excellent artisans, reliable workmen, and of a good faith that every one acknowledges and admires in their commercial dealings; in no country that was or is has the commandment, 'Honour thy father and thy mother,' been so religiously obeyed, or so fully and without exception been given effect to. It is, in fact, the keynote of their family, social, official, and national life."

It remains for me to add a word on the question of the amalgamation of Europeans and Asiatics by inter-marriage. A recent writer has reminded us that in the earlier days of European expansion the proudest grandees of Spain wedded publicly with the daughters of the Mexican nobility and begot children who were honoured for their mixed parentage, while the Portuguese in Asia did not scruple to give their daughters in marriage to rich natives who had embraced the Christian faith. But such marriages have been the exception, and have been influenced by the same considerations that have overcome the pride and prejudice of birth and wealth, of creed and race, or even of colour, in our own country, and brought about marriages that half a century ago would have been thought $2 \mathrm{~B}$ 


\section{THE BROAD STONE OF EMPIRE}

impossible. Still, they remain the exception, and so it is in Asia. Racial inter-marriages are not generally desired either by Europeans or Asiatics. And they tend to grow fewer, because as each racial group approaches social equality, and the equal enjoyment of positions of dignity and emolument, it becomes self-contained and finds within itself the elements of congenial and prudent alliance. Thus there has arisen a social relation of races which has been justly compared to the relation of the fingers to the hand.

I pass on to consider the relations of the white man to the community of African descent in our Crown colonies. The problem is no longer the adaptation of races that have attained to a high degree of civilisation of an ancient type in their country of origin to a new civilisation of modern type. It is the education, in the principles and methods of a foreign civilisation, of a race that has never worked out for itself an original civilisation in the functions of administration, law, religion, literature, art or science. Admitting that in the present stage of evolution of his race the average negro is inferior to the average white man in the arts of civilisation, the question to be decided, and it can only be decided experimentally, is whether the inferiority of the individual is an accident arising out of the circumstances of his past. Through all the history of his race his free activity has been limited by the necessities of slavery, first, in his country of origin, and then in every country to which he has been transported. The civilisation of the Anglo-Saxon is the result of a thousand years 
of evolution from savagery. The social codes and customs of the Saxon hordes that invaded Britain were very similar to those of contemporary African peoples. Their tribal economy was based on the possession of cattle, the tilling of allotments of communal land, the maintenance of the war-host of all able-bodied freemen for plunder and selfdefence, the slavery of captives, and the subjection of women. A thousand years of conflict against the forces of nature and humanity secured the freedom of the Anglo-Saxon; but the qualities that supported him in the desperate struggle were qualities derived from his climatic environment.

In I6I9, at Jamestown in Virginia, the three main types of the human race on the American continent first met, - the Caucasian in the person of the Englishman, the Mongolian in the person of the Red Indian, and the negro in the person of the slave imported from Africa. There were twenty negroes and thousands of Indians. The Caucasian was civilised, but the climatic conditions which had produced his civilisation had rendered him unfit for manual labour in the climate of the Southern States of America. The Red Indian and the negro were savages, but had the capacity which the Englishman lacked. The Englishman's civilisation had taught him to submit to the savages the alternative of slavery or death. The Indian preferred death, the negro accepted slavery. Mr. Booker Washington has observed that "the Negro seems to be about the only race that can look the white man in the face and live-not only live but multiply." $\mathrm{He}$ might have added that his is the only race that can 


\section{THE BROAD STONE OF EMPIRE}

amalgamate with the white man in the production of a race appropriate to climatic conditions demanding capacities that neither the white man nor the negro possesses individually. I do not propose to discuss the problem of the future of the race on the continent of America, but I am bound to consider some bearings of the question of the relations of the European to the African race common to the United States of America and our Crown colonies. On October 26th, 1901, there appeared in The Spectator an article on The Negro Problem of America. The immediate occasion was the incident of Mr. Booker Washington dining with President Roosevelt at the White House, and it may reasonably be assumed that the views expressed represent the opinion of a large community of thoughtful white men and women, not only in the United Kingdom but in every part of the Empire. It said :

"We wish that the President had not been moved to give the invitation, because we do not believe that the recognition of non-existent equality between the races is the way to kill out the white prejudice against the black one.

"There is no equality. As they all inter-breed, it may be taken as certain, that in that far past which it has been the will of Providence to hide so completely from us, all the families of man sprang from one common stock; but it is equally certain that they have developed very unequally, and that the negro stands at the present moment behind both the white and the brown.

"Individuals have advanced to high level, but the race, besides its apparent deficiency in accumulating 
power, retains in Africa, in Hayti, and in the Southern States deep traces of savagery, especially as regards the relations of the sexes, which it will need generations to work out."

Briefly, the assertion that there can be no equality between the white and black races rests on two premises: that the negro race retains deep traces of savagery, especially as regards the relations of the sexes, and that it is deficient in accumulative power.

As regards traces of savagery, apart from the relations of the sexes, the years that have since elapsed have exhibited an uninterrupted record of savagery on the part of white races. I have illustrated the methods by which the American people are dealing with the negro race in the United States. But these methods have a much wider range in the usage of Europe. In November, I 905, the anti-semitic racial prejudices of the Russian people broke out in a series of massacres, and on the 6th, the Press reported:

"Telegrams from Odessa show that almost unspeakable outrages have been committed there under the eyes and even with the active assistance of the military authorities, whose duty it was to repress disorder. The Jewish quarter of the city has been sacked, the authorities declaring that the 'Christian population must be allowed to give vent to their patriotic feelings,' children have been torn limb from limb, men and women beheaded, and old people soaked with petroleum and burnt to death in cellars.

"No reliable estimates can be formed of the number of victims, but they must be counted in 
thousands. It was not till late on Saturday afternoon that, acting under imperative orders from St. Petersburg, the Governor-General took any effective steps to stop the bloodshed."

The protection of the negro race in the Congo is guaranteed by the Powers that claim to represent the highest range of the civilisation of the white man, and yet for years the white man in the Congo has displayed an ingenuity of savagery that admittedly dishonours civilisation. Let it be admitted that the black man has shown traces of savagery in the Southern States, but let it be remembered that in the Southern States the black man has shown more than traces of a humanity hardly surpassed in the annals of Europe. Mr. Archer, in his book Through Afro-America, has recorded that during the civil war, when the Southern planters were fighting for the enslavement of the negro race, the planters' wives and children were left to the protection of the negroes. Had these been the lecherous savages they are now declared to be, they would have written one of the darkest pages of history. Not a single outrage occurred, and scarcely a case of theft or breach of trust. And he quotes an instructive passage from a work of Mr. Nelson Page, The Negro: The Southerner's Problem.

"No race ever behaved better than the negro behaved during the war. Not only were there no massacres and no outbreaks, but even the amount of defection was not large. Many a master going off to the war entrusted his wife and children to the care of his servants with as much confidence as if they had been of his own blood. They acted rather 
like clansmen than like bondsmen. . . . As Henry Grady once said, 'A thousand torches would have disbanded the Southern army; but there was not one." "

This evidence may well be pleaded in defence of the negro to the charge of savagery in the relations of the sexes; but what is to be said of the white man who makes the charge? He forgets that the conditions of slavery maintained for centuries placed the persons of the women of the negro race absolutely at the disposal of the white man. It is asserted, probably with truth, that there is not a single family of honoured name and fame in the history of the Southern States whose blood has not passed into the veins of the coloured community.

We have seen that in Europe the relations of master and servant, which have generally coincided with the relations between rich and poor, have passed through three stages, slavery, serfdom, and service by contract. The latest stage has not expelled the instincts of human nature, which in the case of the negro are called traces of savagery. Adapting the principle of service by contract to sexual relations, it has perfected a costly and elaborate system of machinery, working automatically by the motive power of economic pressure, for the supply of prostitutes on sale or hire to the capitalist who has succeeded the master of slaves and the feudal lord. It is called the White Slave Trade.

I pass on to the assertion of The Spectator that the negro race is deficient in accumulative power. During their forty years of freedom, following 


\section{THE BROAD STONE OF EMPIRE}

two hundred and fifty years of the degrading and debasing operation of slavery, the negro population of about $10,000,000$ have acquired ownership in land to the extent of 36,000 square miles, more than the combined area of Belgium and Holland; and the value of their property is estimated at $£ 200,000,000$. This is mainly the result of industrial education, the negro having learned the lesson that while "being worked means degradation, working means civilisation."

Of the determination of the negro race to avail themselves of the machinery of industrial education as an engine of social progress in the United States there can be no better proof than the Industrial University they have established at Tuskegee in the State of Alabama. It was opened in I88I with one teacher, Mr. Booker Washington, and thirty pupils, in a small rented church, without a single foot of land. Mr. Archer gives the following account of it as it was in 1909 :

"It has now, or had two years ago, 2000 acres of land and eighty-three buildings, large and small. Its property, exclusive of endowment fund, is valued

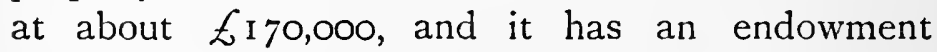
fund of $£ 250,000$. It now accommodates about I 500 students, two-thirds of them male. More than 6000 students have passed through it, counting only those who have remained long enough to benefit appreciably by their course. Of these $6000 \mathrm{Mr}$. Washington declares that, after diligent enquiry (and every effort is made to keep in touch with former students), he cannot find a dozen who are not usefully employed; nor has one Tuskegee graduate 
been convicted of crime. Instruction is given in thirty-seven industries, from agriculture and stockbreeding to printing and electrical engineering."

It is true that in our tropical colonies the emancipated negro was slow to learn the lesson of the dignity of labour, with the result that he was displaced by an Asiatic immigration; but he is finding himself and is learning the lesson, largely through the agency of the educational forces represented by the Royal Botanic Gardens, Kew, as will be shown in another chapter.

In the meantime, such has been the energy and capacity of the Afro-European population in the Crown colonies, where they form the bulk of the general community, that there is no department of Government, executive, administrative, or judicial, in which they have not held the highest office with distinction, no profession of which they are not honoured members, no branch of commerce or industry in which they have not succeeded. I have illustrated in another chapter their position in the political and social system of Mauritius, and what I have said applies equally, so far as my experience goes, to their position in the West Indies.

In the last analysis the struggle for the control of the tropics is a struggle for the control of the only agency by which they can be made of value,-a coloured population,- -and it is certain that in the scramble for Africa the native population will be an asset of supreme value. How is it to be controlled, -by force or by consent? The year 1858 was marked by the assertion of two distinct policies 


\section{THE BROAD STONE OF EMPIRE}

as means to secure the control of native populations, -the policy of Queen Victoria's proclamation to the Princes and Peoples of India, which had been asserted in South Africa in nearly identical terms ; and the policy of the South African Republic, declared in their Grondwet, that there should be no equality between white and black men in the State or in the Church. In the same year the Governor of Mauritius was a distinguished administrator who had an intimate knowledge of the West Indian population of African descent. After gaining some experience of the race in Mauritius he submitted to them this proposition: "If the Creoles of Mauritius,-chiefly consisting as they do of coloured people-could be made to appreciate liberal institutions and popular power for the purpose of Government and legislation, and could be made to attribute the freedom and liberty they enjoy, and all that may hereafter be added to their constitution, to the advantages of living under a British Government-similar to which no other in the world is to be found; if they could be safely instructed in the art of self-reliance, and taught to believe that the legislation and Government of the Colony, and the prosperity, defence and happiness of the people rested chiefly with themselves -if they could believe that on them would rest the obligation of supporting and defending Mauritius against all the world - not as mere British subjects struggling against French or other foreign aggression-but as Creoles of Mauritius defending their own country, property and possessions, then I think that their 'amour propre' would give them a feeling of pride at being regarded as its guardians 
and protectors, satisfied with the British protection they enjoy, and assured that neither France nor any other country that might acquire dominion here, would ever give them or allow them to retain, the same freedom, privileges and power.'

If we are to hold our own in the conflict for the control of the tropics it is on a population animated by such sentiments that we must rely.

Of the comparative value of the two policies we have had quite recently remarkable proof in the West Indies.

Mr. Froude, in The English in the West Indies, speaks in a spirit of unreasonable prejudice of the negro and his descendants, but he is compelled to recognise the loyalty of the race he depreciates to British rule. From the day he left England to the day he left the West Indies, he was constantly assured that the West Indian white community desired to be 'taken into partnership' by the Americans, but he seems to have been convinced that the coloured population had so little of such desire that the 'partnership' is impossible. He was right. During my experience of the darkest days of the fortunes of the West Indies, I was assured more than once that the policy of the Colonial Office was creating a sentiment that 'partnership' with America would be better. But those who gave me this warning in my official capacity, admitted at once that the coloured people would not stand it. That people in England and even the Colonial Office have very little idea of the sentiment of the coloured people towards America was made clear at the time of 


\section{THE BROAD STONE OF EMPIRE}

the Jamaica earthquake in 1907. The American Admiral must have been entirely unconscious of it when, with the best intention, no doubt, he landed American troops, against the expressed wish of the Governor, for the protection of order.

The solution of the colour problem is not likely to be found in any immediate formula of universal application. The balance of interests is not capable of mathematical adjustment. We must be patient of delay, content to meet every occasion that arises with sobriety of mind and temper and with flexibility of resource. At the same time we must bear constantly in mind that we are dealing with the special problem of the century and the destiny of our race; and we must adhere with moral tenacity and intellectual courage to the faith that the British Empire can only be maintained by the principles that have established it. 


\title{
CHAPTER XII
}

\author{
HEALTH
}

I

SOME IMPERIAL ASPECTS OF HEALTH IN

THE TROPICS

We have traced the relations of Europe with the tropics through three stages, - a period of plunder, a period of trade, and a period of occupation. The period of occupation has revealed unexpected sources of wealth. There was a good deal of romance in the influences that inspired the adventurers of the earlier periods, but there is nothing of romance in the solid substances that have of late excited the cupidity of nations and engaged all the Great Powers in conflict for a share of the tropical regions of the earth. With the economic uses of the tropics I deal elsewhere, but in proportion as the experience of occupation has enabled us to realise them, it has compelled us also to realise the extent to which the agencies of beneficial occupation,-industry, commerce, military and naval defence, and good government-are dependent on the preservation of health against tropical diseases. 


\section{THE BROAD STONE OF EMPIRE}

All industrial enterprises depend upon an adequate and regular supply of manual labour. In the tropics the supply is controlled by three material facts. First, the most profitable lands,for instance, the lands most appropriate to the cultivation of sugar and cotton-are largely found in malarial areas with no efficient labour-supply. Secondly, and consequently, with the exception of India where there is a pressure of population, we have no tropical possessions of any commercial importance in which the elementary operations of industry are not carried out by imported labour. And, thirdly, experience has proved that the migration of large bodies of men from tropical areas of economic pressure, or from conditions to which they have become adapted, is always attended with the danger of spreading disease.

In these circumstances the constantly increasing demand for labour to exploit new areas brings home to us the constant wastage from disease. Within limited areas of British India, during the first seven years of the century, nearly 6,000,000 persons, mostly in youth or in the prime of life, perished from plague alone. In 1907 the average mortality exceeded 20,000 weekly. In Hong Kong and Mauritius, during the same period, the mortality from plague was hardly less serious in proportion to area and population. In 1900 plague appeared for the first time in South Africa; a few years later it visited West Africa, and passed on to the West Indies and South America. If in Africa and America its progress has been promptly arrested, it is to the scientific study of tropical diseases that 
we owe this triumph. Of the contemporary wastage of labour from malaria, yellow fever, cholera, and other tropical diseases I can give no estimate. But the stations I have mentioned on the itinerary of plague illustrate the distribution of tropical diseases from centres of origin following the migration of labour. A few years ago an outbreak of beri-beri among the Chinese introduced into South Africa first directed public attention in England to that terrible disease. Meanwhile the expansion of English interests in Equatorial Africa has been accompanied by the introduction of sleeping sickness into Uganda. Sir David Bruce, R.A.M.C., in a paper read in 1908 before the South African Society, traced the spread of the disease following the increased demand for labour, and insisted on the duty of England to arrest its further progress by preventive measures, and not to rest until it is stamped out.

Many years ago Livingstone declared the tsetsefly to be the greatest obstacle to civilisation in Africa. The researches of Sir David Bruce and others have thrown the light of science on the processes by which it works. The infection of sleeping-sickness is caused by a parasite called a trypanosome transmitted by a tsetse-fly, which is thus the carrying agent of one of the deadliest of the known diseases of humanity; ${ }^{1}$ while varieties of the same parasite and the same fly are the infecting agents of no less deadly diseases among animals. In this way the tsetse-fly is the carrying agent of

${ }^{1}$ In a certain proportion of cases seen in England the disease has caused no symptom for three, four, five, and even seven years. 


\section{THE BROAD STONE OF EMPIRE}

diseases equally fatal to industry and to commerce; commerce implying the transport of commodities to and from profitable markets by land and sea.

Among the basal facts of economic geography we have to recognise the extent to which all methods of land conveyance,- - human labour, animal draught, and mechanical transport-are affected by tropical diseases. The abolition of slavery, with the substitution of animal draught for carriage by native bearers, has involved the movement of animals on a large scale, with exactly the same results that have followed the migration of large masses of men,-results that paralyse every operation of private enterprise and every department of the public service. The imperial importance of the study of diseases of animals is now recognised by the Universities and the Public Departments, and has added appreciably to the dignity of the profession of the veterinary surgeon.

The exigencies of commerce, baffled by disease, have naturally demanded the substitution of mechanical transport for animal draught ; but here again we are confronted by the fact that the construction of railways through malarial areas is always accompanied by high rates of disease and mortality. There is scarcely an area of activity in which a knowledge of the conditions of health and hygiene in the tropics is more important.

But the larger operations of commerce in the interchange of products between the component parts of the Empire in temperate and tropical zones are conducted mainly by sea, and here again we find that the removal of masses of tropical 
products is attended with the same danger as the removal of men and animals. The sea-borne commerce of the tropics has, therefore, to contend with the formidable obstacles of quarantine. Scientific knowledge of the origin and processes of tropical diseases has already done much to modify the laws and regulations affecting quarantine. The facilities offered by the Suez Canal for the introduction into Europe of the diseases of the East, in particular plague and cholera, led to the Venice International Sanitary Conference of 1892 and the Paris Convention of 1894 . To reconcile the interests of personal and family security with the exigencies of trade and shipping is one of the gravest responsibilities the Governments of tropical colonies have to undertake.

The Venice Conference and the Paris Convention had for their object to reconcile these conflicting interests, and to regulate on scientific principles the periods of detention and the processes of disinfection. Although all our tropical colonies did not become parties to the Paris Convention, they have all had the same object in view. But there is still much to be done, and my own experience has convinced me that a scientific knowledge of the origin and processes of disease, both of men and animals, bears nowhere more intimately on the commerce of our tropical dependencies than in the enactment and enforcement of laws and regulations relating to quarantine.

It is necessary to anticipate that the opening of the Panama Canal will add a fresh element of risk in the distribution of tropical diseases, particularly 
yellow fever. The agent Stegomyia calopus is common in China and Singapore, and the mosquito is carried by sea in ships for some weeks.

Essential to the economic development of the tropics is the security of their sea-borne commerce. The health of our sailors in tropical waters, and of our soldiers in tropical fortresses and defended coaling-stations, is, therefore, a national asset of value. Some years ago it was the policy of the Imperial Government to make the Island of St. Lucia a defended coaling-station of the first importance in the Caribbean Sea. Fortifications and barracks were constructed at great cost, but the troops had hardly been transferred to them when an epidemic of yellow fever broke out among the sailors of the training squadron which happened to be in the harbour, and the soldiers of the garrison. As I was Governor of the Windward Islands at the time, I can speak from experience of the serious consequences of this incident, and I can assert with confidence that it would not have occurred had the nature of the infection been understood as it now is. I believe that the preventive measures adopted against yellow fever, since the discovery of the infecting agents, have been eminently successful in St. Lucia.

While speaking of the results of research as affecting the health of our naval and military forces in the tropics, I cannot refrain from a word on Sir David Bruce's work in the sub-tropical Island of Malta. $\mathrm{Up}$ to five years ago the admissions to hospital of men suffering from Malta fever amounted to a considerable reduction of the strength. The research 
work of the Mediterranean Fever Commission, which led to the discovery that goats' milk is the agent of infection, has stamped out the disease, so far at least as our soldiers and sailors are concerned. The problem of securing complete immunity for the civil population is a question of expense.

And now one word on the imperial aspect of hygienic research as an agency of good government and civilisation. The development of our tropical territories is carried on almost universally by workmen of Asiatic or African origin under the supervision of a handful of Europeans. Administrative efficiency was long seriously impeded by the difficulty of finding qualified candidates for employment in regions where even a short period of service brought almost certain sickness and probable death. A typical, if exceptional, instance of the danger of residence on the West African Coast was referred to some years ago in Parliament. A despatch was received in London, shortly followed by the news that the Colonial Secretary who drafted it, the clerk who copied it, and the Governor who signed it, had all died before it reached the Colonial Office. In I 895 the number of European officials on the Gold Coast was I75; of these seventeen died and twenty-four were invalided. In 1896 the number was i 76 , of whom fifteen died and twentysix were invalided. These figures take no account of the non-official white population, among whom the mortality was at least as high. Corresponding returns from other West African colonies were scarcely less alarming. It was stated on good authority that at Lagos forty-six out of I40 
resident Europeans died, about the same time, during a period of fifteen months, and that during another period of six months seventy-two died out of a white population of 200 . Outside the Colonial Office and trading associations engaged in the commerce of colonial products, it was chiefly on the occasions of military expeditions, - such as the Ashanti and Gold Coast Wars-that the terrors of service in our tropical possessions were brought home with painful intensity to the consciousness of the British public.

Scientific research has at last analysed the vague generalisation styled 'climate,' and found that tropical diseases are specific infections by agencies working in accordance with ascertained natural laws. And already the knowledge has effected such a change in the conditions of life that appointments in Africa are eagerly sought for by officials and administrators of proved ability in the Imperial service. But the functions of the Medical and Health Departments have a much wider range than even the welfare and safety of European officials. The most successful missionary enterprises I have known have been those which have most closely associated religious teaching with the practice of medicine, and more or less directly with industrial work. In the nature of things it must be so. It is no exaggeration to say that the history of the tropics, prior to European occupation, was a record of plague, pestilence, and famine, battle and murder and sudden death. No wonder that the communities living in so malignant an environment have thought it more politic to propitiate the spirit 
of evil than to appeal to the goodness of God. No wonder that fetishism flourishes in all the lower strata of tropical humanity. We offer to these communities a new order of things. We endeavour in the first place to relieve them of the environment of plague and pestilence by the methods of science, and so teach them by practical demonstration that science is merely the right interpretation of the ordinances of nature and the will of God. We then encourage them to work out their own salvation from famine by developing the resources of the soil by industry. And in the new environment thus established we promise to save them from battle and murder and sudden death by the civil and military arms of a just and efficient administration.

MR. CHAMBERLAIN AND THE HEALTH OF THE EMPIRE

The campaign which is being carried on against disease in the tropics owes its origin in great measure to the initiative and encouragement of $\mathrm{Mr}$. Chamberlain. The commercial development of our Crown colonies had engaged his attention from the first day of his entrance on office as Colonial Secretary; and he quickly realised how seriously, within their area, the future of all imperial interests, administrative, commercial, and industrial, was threatened by the ravages of disease. Lord Beaconsfield's formula, Sanitas sanitatum omnia sanitas, was the principle of his administration in dealing with these regions of the Empire. 


\section{THE BROAD STONE OF EMPIRE}

Towards the end of the year 1897 his attention was very definitely directed to the importance of scientific inquiry into the causes of malaria, and of special education in tropical medicine for the medical officers of the Crown colonies. In an address delivered at St. George's Hospital, at the opening of the winter session in October, I897, Sir Patrick Manson urged the importance of special training in tropical medicine, seeing that more than one-fifth of the medical graduates in Great Britain and Ireland practise in tropical climates, or, being in the army or navy, may at any time be called upon to do so. It was pointed out that England is the centre of a great and growing tropical empire, with fields of disease widely different in many respects from the diseases of temperate climates, and demanding special knowledge for their diagnosis and successful treatment, while the diseases of temperate climates were practically the only ones about which the students of our medical schools received instruction. Sir Patrick Manson declared emphatically that the course of instruction in general medicine received in the country was utterly inadequate to qualify for tropical practice.

This address was to a large extent the immediate initiative of Mr. Chamberlain's subsequent action, and may well be said to mark an epoch in the history of the study of medicine throughout the Empire. The following quotation will serve to indicate why so little had been done, and shows some consequences of this neglect:

"A principal reason why hitherto there has been so little done in this matter is this, candidates 
for medical degrees know very well that they will not be asked any questions about tropical diseases by their examiners, and so they have not demanded instruction on this subject. And the reason why questions are rarely put on tropical medicine is that the leaders of the profession, those who man our hospitals, who fill the teaching chairs, who examine for degrees, who grant licences to practise, who make the regulations for the education of the youth of the profession, are, in almost every instance, men who have never practised in warm countries, and who themselves have never felt the necessity for a wider and more practical knowledge of the diseases peculiar to these climates. Not having themselves felt the want, they have been slow to acknowledge that such a want exists, and slower still to apply the remedy.

"But ask those who are best qualified to express an opinion on this subject. Ask the medical men who have themselves felt the responsibilities of practice in the tropics, and more especially those of them who have endeavoured to follow recent developments in tropical pathology. Ask them if they do not think that the medical man who goes out to battle with tropical disease should have some special instruction and training for the very special and responsible work he has before him, and if they do not think that the medical authorities should take care that the men who do so go out to practise should be properly qualified so far as teaching can qualify. I am sure of their answer. Unfortunately, most of the men of tropical experience live and practise away from the great medical 
centres. They are hardly represented on the medical teaching, graduating, or legislating bodies, and so it comes that their opinions do not make themselves felt, and that a much-needed reform is delayed.

"It is more especially of recent years, partly in consequence of the enormous expansion of our Empire, and partly in consequence of the advances in tropical pathology which have signalised the last two decades, that the claims of tropical medicine have become urgent. Formerly the little that was known about tropical disease could be carried in a waistcoat pocket. But of late years so great has been the advance that nowadays the subject is quite as extensive and quite as special, so to speak, as ophthalmology, dermatology, gynæcology, or any of those departments of medicine which claim and receive special teaching,-more so. When the practitioner in this country is puzzled about a case it is an easy matter for him to call in someone known to be familiar with the class of case he is in trouble about. But in the wilds of Africa, in the islands of the Pacific, in lonely stations in India or China, there is no consultant to fall back upon. The practitioner there has himself alone to depend upon. And woe to his patient, and, if he has a conscience, to his future peace of mind, if he is not up to date in his knowledge."

Early in $1898 \mathrm{Mr}$. Chamberlain submitted to the War Office, the Admiralty, the India Office, and the Foreign Office the draft of a circular which he proposed to address to the General Medical Council and the leading British medical schools, urging the desirability of extending the teaching of tropical 
medicine in this country. It was Mr. Chamberlain's desire to give additional weight to his appeal for the co-operation of the Council and medical schools by securing the approval and support of those departments, and on March I Ith the circular was issued, enclosing a copy of Sir Patrick Manson's address. The correspondence in reply showed that in upwards of twelve British medical schools, some of them situated at large seaports, arrangements either already existed or were about to be made for giving special instruction in tropical medicine. A resolution was adopted by the General Medical Council in the following terms:

"That while the Council is not prepared to recommend that tropical medicine should be made an obligatory subject of the ordinary medical curriculum, it deems it highly desirable, in the public interest, that arrangements should forthwith be made by the Government for the special instruction in tropical medicine, hygiene and climatology of duly qualified medical practitioners who are selected for the colonial medical service, or propose to practise in tropical countries."

It was at first suggested that arrangements might be made for the training of colonial medical officers at the Royal Naval Hospital at Haslar, or at the Royal Victoria Hospital for soldiers at Netley; but after full consideration it was decided to provide a special school of tropical medicine in connection with the Albert Dock branch of the Seamen's Hospital. The principal advantages of this scheme were stated in a letter addressed to the Colonial Office by the Seamen's Hospital Society. The main 
points may be briefly summarised. The hospitals and dispensaries maintained by the Society furnished an amount and variety of clinical material for the study of tropical diseases not at that time to be found elsewhere in the United Kingdom. The average annual number of typical cases was 190 ; these were mostly acute, and included representatives of the chief native races of tropical regions as well as Europeans. At the time the number of beds at the branch hospital at the dock gates was only eighteen, but the Committee had arranged to increase it to thirty. They proposed that if a School of Tropical Medicine was established the number should be further increased to forty-five. They stated that it would be necessary to erect suitable school buildings, with sleeping accommodation for students, laboratories, offices, etc. The necessity for providing residential accommodation for students was shown to be due both to the position of the hospital at some distance from London, and also to the fact that it was desirable for students to be on the spot during the whole twentyfour hours, throughout the short period of time they would probably devote to the subject. The arrangements it was proposed to make for the instruction of the students were detailed, and financial arrangements for the immediate present and the future were discussed.

The scheme offered some further advantages. Sir Patrick Manson, the medical adviser to the Colonial Office and the Foreign Office, was a prominent member of the staff of the hospital, and would be able personally to supervise the 
training of colonial medical officers for the colonies and protectorates, to advise the Secretary of State as to their qualifications, and to adapt the instruction given at the hospital to the requirements of the services.

In these circumstances Mr. Chamberlain, after communication with the Treasury, accepted the scheme proposed by the Committee on the terms that a contribution should be made on behalf of the colonies and protectorates concerned, and that a representative of the Colonial Office should be admitted to the board of management of the hospital. As regards the contribution, the Treasury, bearing in mind that the Imperial Government is ultimately responsible for the Crown colonies and protectorates of the Empire, and is thus strongly interested in any measure for maintaining the health and efficiency of the administrative staff, consented to provide one half from Imperial funds, "On the understanding that such Imperial grant will defray the shares of all Exchequer-aided tropical colonies and protectorates in such initial cost, and that the remaining moiety will be contributed by other colonies and the Niger Coast Protectorate." The allotment of the expenditure to be borne by the Crown colonies was adjusted in accordance with arrangements to which the colonies willingly agreed.

Subsequently the Colonial Governments were invited to concur in arrangements for the training of their medical officers, on condition that all such officers, who might in future be selected for appointments in the medical service, should undergo a two months' training at the school; and 


\section{I2 THE BROAD STONE OF EMPIRE}

that the cost of their tuition, board and lodging during that period, as well as the tuition fees for officers already in the service, who might desire or be required to attend a course of instruction while on leave of absence, should be paid by the colonial Governments.

While Mr. Chamberlain was securing the cooperation of the colonies and the Imperial Treasury, the Seamen's Hospital Society was appealing to the generosity of its friends. The names of two among the earliest to respond may be mentioned: Sir John Craggs provided a scholarship of $£ 300$ a year for three years, for purposes of research ; and Mr. Bomanji Dinshaw Petit, a wealthy Parsee, enriched the school by a donation of 100,000 rupees.

As soon as the arrangements for a school of tropical medicine had been concluded, Mr. Chamberlain wrote to Lord Lister, then President of the Royal Society, telling him what had been done, and adding, with characteristic energy, "I am not satisfied to rest at this point, and wish to invite the co-operation of the Royal Society in taking further steps." An extract from Mr. Chamberlain's letter and Sir Michael Foster's reply furnish an interesting record of prompt action.

\section{Mr. Chamberlain to Lord Lister.}

Downing Street, July 5, I 898.

"It is my desire that a thorough investigation should be undertaken into the origin, the trans- 
mission, and the possible preventives and remedies of tropical diseases, especially of such deadly forms of sickness as the malarial and blackwater fevers prevalent on the West African coast; and, feeling assured that the object is one which will commend itself to the Royal Society, I would invite them to take the matter in hand, in conjunction with, and after conference with, the Colonial Office. There should be, I assume, enquiry on the spot by scientific experts; and it would be well, in my opinion, that these experts should be appointed by, and take instructions from, your colleagues and yourself.

"My request then is, in short, one for a grant from the funds of the Royal Society for the specific purpose of investigating disease and combating its effects in the malarious regions of the British Empire. If such a grant can be given, and if the Royal Society will undertake the disposal of the money and the carrying out of the object in view, your Lordship may be assured that I will give all the assistance in my power; and, further, I am prepared, within reason, to promise on behalf of the Colonies concerned a grant of equal amount to that which the Society may contribute.

"I am given to understand that the last meeting of the Council of the Society before the autumn will be held on Thursday next, July 7 th, and it would be a pleasure to learn that at the meeting a Committee had been appointed to consult with representatives of the Colonial Office as to the necessary arrangements for carrying out the proposals to which this letter refers." 
The Royal Society to Colonial Office.

"SIR,

Burlington House, London, W., July 7, I 898 .

"Your letter of July 5 to the President was this day laid by him before the Council of the Royal Society, and it was resolved to appoint a Committee, consisting of the President and Officers, Dr. J. N. Langley, Professor E. Ray Lankester, and Professor Burdon Sanderson, in accordance with your letter.

"It was further resolved that the Royal Society should make an initial grant of $£ 300$ from the Government Grant Fund towards the expenses of the above.

\section{Foster,} Secretary, R.S."

Negotiations between the Colonial Office and the Royal Society were actively carried on, and it was eventually decided that, for the purposes of the investigation proposed by Mr. Chamberlain, two inquirers should be nominated by the Royal Society and one,-a nember of the colonial medical service -by the Secretary of State; that the whole expenses of the third inquirer should be paid from colonial funds; and that from those funds a sum not exceeding $£ 2,400$ should be contributed towards the expenses of the other two, the Royal Society contributing the balance, estimated at $£ 600$.

The inquiry was to be conducted under instructions from a Committee consisting of the members 
of the Royal Society named in Sir Michael Foster's letter of July 7 th, supplemented by two representatives of the Colonial Office, Sir Patrick Manson and Mr. (now Sir Charles) Lucas. These negotiations were concluded in the first days of September, 1898 ; so that, within a year of the date of Sir Patrick Manson's address at St. George's Hospital, arrangements had been made for instituting a school of tropical medicine and a scientific inquiry into malaria under the guidance of the Royal Society. Incidentally, a powerful impetus had been given to the study of tropical medicine in the leading medical schools of the United Kingdom.

Time was required for the construction of buildings and the completion of arrangements necessary to carry out the undertaking entered into by the Committee of the Seamen's Hospital, and the date fixed for the opening of the London School of Tropical Medicine was October 2nd, i 899 . It was opened on that day. In the meantime, however, Mr. Chamberlain had been informed of the establishment in Liverpool of a School of Tropical Medicine in connection with University College and the Royal Southern Hospital. The exceptional advantages offered by Liverpool were set out in a letter addressed to the Colonial Office by Sir Alfred Jones, acting as chairman of a Committee of gentlemen, representatives of the shipowners and merchants of the city, the Royal Southern Hospital, and University College, appointed to establish and govern the scheme. The foundation of the school was due to the initiative of Mr. Chamberlain's letter of March i ith, I898, addressed to the leading 


\section{I6 THE BROAD STONE OF EMPIRE}

British medical schools. The movement was generously supported by Sir Alfred Jones, who offered an annual grant of $£ 350$ towards its maintenance. It was the desire of the Committee to obtain the assistance of Government by a formal recognition of the school, on the same level as the London School of Tropical Medicine, an annual grant in aid of maintenance, and a donation towards a contemplated considerable extension of the scheme, including the erection of additional buildings. To the first request Mr. Chamberlain eventually consented; the financial assistance asked he was unable to grant. The application of the Committee was accompanied by a description of the school, and of the changes it was proposed to make.

The port of Liverpool offered great advantages for the study of tropical diseases, owing to the steamship lines which put it in constant communication with tropical regions, and especially with West Africa, while already the Royal Southern Hospital, placed close to the dock, annually treated a number of patients suffering from tropical diseases. One floor of this hospital, containing sick and isolation wards with a capacious laboratory and offices, it was proposed to set apart for the study of these diseases. Within easy reach were the ThompsonYates laboratories, admirably fitted up with a pathological class-room capable of accommodating sixty workers, a museum, and a bacteriological laboratory. For the furtherance of research the Committee not only contemplated the inmediate appointment of a lecturer on tropical diseases and a demonstrator of 
tropical pathology, but were prepared to organise expeditions for the study of tropical diseases on the spot. For students from a distance residential accommodation was to be provided in connection with the hospital.

By the month of October, 1899 , the London and Liverpool Schools of Tropical Medicine were in full working order, and the Malaria Commission, appointed under the joint Committee of representatives of the Royal Society and the Colonial Office, was actively engaged in researches in Africa. But before giving a brief account of the work of the schools and the investigations of the Commission, I must refer to $\mathrm{Mr}$. Chamberlain's work in dealing with some other questions affecting the security and comfort of life in Crown colonies, to which his attention was given while the negotiations I have described were going on.

Early in $1898 \mathrm{Mr}$. Chamberlain's attention was called by Sir Patrick Manson to the advantages which promised to follow an improvement of method in the medical and sanitary reports sent home annually from the Crown colonies, and on February and Sir C. Gage-Brown, at that time medical adviser to the Colonial Office, was asked to preside over a Committee to consider the matter. The Committee included Sir Patrick Manson and three other medical men of long colonial experience. On July i ith the Committee submitted a model form of medical report to be adopted in all the Crown colonies, and recommended that the purely medical parts of these reports should be separated from the administrative and financial statements 


\section{I8 THE BROAD STONE OF EMPIRE}

with which they had been associated, and should be bound up in a separate volume, with an appendix containing special papers upon the different diseases of the different colonies; the volume to be freely circulated in the Government service, presented to the more important medical libraries, and placed on sale. It was hoped that in this way the value of the colonial medical reports would be very much enhanced, the members of the service brought together by co-operation in a work of common interest, useful knowledge acquired in one colony disseminated among the medical profession of all, encouragement given to work and to friendly competition, and important additions made to medical science. On July $25^{\text {th }}$ the model report was transmitted by circular despatch to the Governments of the different colonies, and suggestions invited. In the light of the replies received to this despatch the model report was revised and finally adopted. The reports when received were collated by Sir Patrick Manson and the more important presented to Parliament.

Intimately associated with the work on which $\mathrm{Mr}$. Chamberlain was engaged was the question of enlarging the British Pharmacopœia so as to adapt it to Indian and colonial requirements. The use of local herbs and drugs is extensively practised by the natives of all our tropical colonies, even where an organised medical service of graduates exists, and my own long experience has convinced me that many valuable lives have been lost by the unwillingness of medical practitioners, and more especially young Government medical officers fresh from their 
studies in the schools of the United Kingdom, to avail themselves of the aid of the empiric native practitioners, or to make use of local remedies, even those of proved efficiency. In my official capacity, when administering the government of Crown colonies, I have frequently discussed this matter with the principal Government medical officers, and I am bound to declare that I have found many of them as hostile to the use of such remedies as were their predecessors to the use of quinine in the seventeenth century.

In an extract from Sir Patrick Manson's address at St. George's Hospital, a reason has been assigned for the inadequate attention paid to the study of tropical medicine in the United King. dom, and probably some analogous reasons may have delayed a revision of the Pharmacopœia, though the want had long been felt in India and in the colonies. So long ago as I 886 the question of introducing changes, to adapt it to Indian and colonial requirements, was brought before the General Medical Council, but no definite steps were taken for several years. In I 892 , however, a communication from the India Office came before the Council, accompanied by reports from medical authorities, showing that drugs indigenous to India might be substituted for some of the drugs included in the Pharmacopœia, and on May 26th, I893, the following cautious resolution was adopted by the General Medical Council :

"That the Pharmacopoia Committee be authorised to enter into correspondence, through the Privy Council, with the India Office and the Colonial 


\section{THE BROAD STONE OF EMPIRE}

Office, with a view to ascertaining in what degree, if any, the British Pharmacopœia can be better fitted than at present to meet Indian and Colonial requirements as regards important natural drugs and pharmaceutical preparations."

On the part of the colonies, action was taken by Lord Ripon, then Secretary of State, with the result that important information was contributed by the medical and pharmaceutical bodies of the principal colonies. Three valuable reports were received from the Government of India. The suggestions contained in these communications, expressing the wishes of the colonial and Indian medical authorities with respect to additions, omissions, and the recognition of specified locally grown drugs, were fully considered, and in a large number of cases changes in accordance with them were made in a revised edition published in 1898 . It was recognised, however, that these changes were merely a step preparatory to the ultimate production of a complete Imperial Pharmacopœia, and it was stated in the preface to the work that the Council had in contemplation the early preparation of an addendum, in which plants and substances suggested for inclusion by Indian and colonial authorities would be more fully dealt with. It was added that the Council confidently anticipated the co-operation of all medical and pharmaceutical bodies in the British dominions for the eventual realisation of the Imperial project.

Needless to say, the prompt co-operation of $\mathrm{Mr}$. Chamberlain was not wanting. On February 22nd, 1899, Dr. Attfield, the editor of the Pharma- 
copœia of 1898 , transmitted to the Colonial Office a report showing what the Medical Council had done, was doing, and proposed to do in the matter, with a letter of suggestions for consideration by the medical and pharmaceutical authorities in India and the colonies. On February 25th the report and letter were transmitted to the colonies by a circular despatch desiring officers administering governments to bring the report and letter before the chief medical authorities of the colonies under their government, with a request that they would do their best to support and strengthen the project of the Council.

The result of this correspondence was the publication in 1900 of an Indian and colonial addendum, in accordance with the provisions of the Medical Act, 1862.

One of the earliest questions connected with the preservation of life in the tropical Crown colonies to which Mr. Chamberlain devoted his attention at the Colonial Office was the subject of providing for the care of the sick by trained nurses. In the tropical colonies generally the European community is small in numbers, being limited to Government officials and the managers and employés of agricultural and commercial enterprises. In the older colonies the local Governments have provided excellent hospitals which have brought medical aid and careful nursing to the natives and poorer classes of the community, but these institutions have not generally benefited, as, indeed, they were not designed to meet the needs of, the European community. Among the most urgent of these needs was the want of skilled nursing 


\section{THE BROAD STONE OF EMPIRE}

in sickness. On the initiative of ladies interested in the welfare of our countrymen in the Crown colonies, by reason of personal residence or the official position of their husbands, a movement, encouraged by Lady Knutsford, was started which led to the foundation of the Colonial Nursing Association. The objects of this undertaking were thus stated by its promoters.

"The Association has been formed with a view to meeting the great need for skilled private nursing experienced in many of the Crown Colonies, and in some British communities in foreign parts. This need has been strongly represented by medical officers abroad, who in many places attribute the high percentage of deaths to the impossibility of obtaining trained nurses. Individual and isolated efforts have been made to remedy this state of things, but in most cases without permanent success. In many places such hospitals as exist are inadequate, unsuitable, or for various reasons not available, while skilled private nurses cannot be obtained, principally for the following reasons :

" $\mathrm{I}$. The shifting character of some of the communities themselves, and their consequent inability to absolutely guarantee the cost of maintenance of the nurse whilst in the colony, and her passage out and home, and also to meet the exceptional expenses which often arise, such as those entailed by a necessary but unexpected change of nurses, owing to failure of health, etc. It cannot be expected that the best class of nurse will leave her own country to go abroad without some definite guarantee securing her position and salary. 
" 2 . The difficulty of a distant colony or community securing from England, without any central organisation in England, qualified nurses suited to its particular needs.

"The object the Colonial Nursing Association has in view is to meet these difficulties.

"( $a$ ) By raising a fund from subscriptions and donations at home.

"(b) By providing qualified nurses through the home organisation, which is in connection with nursing associations and interests in England.

" $(c)$ By guaranteeing from its funds to those nurses sent abroad their salary and passage money to and from the colony.

"(d) By assisting financially those colonies and communities which, though greatly in need of a nurse, can show that they are unable themselves to bear the full expense of her maintenance and travelling expenses from and back to England.

" $(e)$ By assisting to meet, as far as the funds of the association will permit, exceptional expenses such as those entailed by the death or illness of a nurse before her full term of engagement has expired.

"It should be understood that the Home Association is not intended to supersede the efforts of the colonies and communities themselves to provide for all expenses incident to the supply of nurses, but to supplement them in case of real need."

The undertaking was of a purely private nature, maintained by private funds, but it was felt that, in order to carry out the objects of the association, it was essential to have the moral support 


\section{THE BROAD STONE OF EMPIRE}

of the Colonial Office. Mr. Chamberlain was approached, and lost no time in referring the general question of providing trained nurses in Crown colonies to a conference of medical officers of colonial experience, presided over by Sir C. Gage-Brown. Copies of the report of the conference were transmitted to the Governors of the Crown colonies on June 26 th, I 896 , with a request for their advice on the suggestions of the conference with regard to the particular circumstances of the colonies under their government. In a separate despatch Mr. Chamberlain forwarded to them the prospectus of the Colonial Nursing Association with a recommendation that, although the scheme was entirely independent of the Government, they should do all in their power to encourage it in every colony where the want it was intended to supply existed.

The scheme was welcomed with enthusiasm in the Crown colonies and protectorates, and encouraged at home by the active interest in the work taken by Mrs. Chamberlain. It was certainly in the fitness of things that, while the great Colonial Minister was rendering Imperial service to the cause of health and sanitation by the methods that have been described, the Minister's wife should encourage the womanly work of the Nursing Association. Mr. Chamberlain's support secured rapid development of the work, and in I 899 the Association was partly reconstituted with a president, a council, an executive committee, and honorary officers. At the annual meeting, held at Stafford House in that year, the resolution 
adopting the report was moved by Mr. Chamberlain and seconded by Mr. Asquith. Both expressed their conviction that the field of work was ready for the harvest, and in his official capacity Mr. Chamberlain testified to the sincerity with which the exertions of the Association were appreciated in the colonies.

Such is an outline of the measures initiated or encouraged by Mr. Chamberlain up to the year 1900 in the direction of securing health, strength, and efficiency for our tropical colonies and protectorates. They may be classed under the following heads :

Scientific inquiry into the causes of tropical diseases ;

Education in tropical pathology for the medical officers of the Crown colonies and protectorates;

The collection and publication of reliable annual records of work and research carried on by the medical staff in their various spheres of duty;

The preparatory measures necessary to the ultimate production of a complete Imperial Pharmacopœia ;

Provision for the care of the sick by trained and skilled nursing.

The results accomplished by the agencies and methods described, and some indication of what remains to be done, must now be considered. 


\section{THE BROAD STONE OF EMPIRE}

III

SCHOOLS OF TROPICAL MEDICINE

\section{The London School}

The work of the School falls naturally under two heads,-education and research. The premises assigned to the teaching of tropical diseases were specially built for the purpose, and the laboratories are fitted with the most modern appliances and apparatus; while the constant attendance of the medical superintendent and tutor ensures the observation and study of all special cases of tropical disease brought to the wards in their acute stages from nearly every tropical country. Bacteriology and animal parasitology, in their practical application to clinical work, are systematically taught; pathological anatomy is demonstrated in the laboratory and in the post-mortem room as opportunity offers. In a word, the student is taught to deal with the problems of tropical disease aided by the most advanced laboratory methods, technique, and apparatus. It is above all an object of the School not only to acquaint the student with the known diseases of the tropics and their recognised treatment, but to put him in the way of observing, recording, and studying scientifically future problems that may present themselves to him when thrown on his own resources in his sphere of labour. It is claimed that every student who has completed his course at the School has gone out not only qualified for actual practice in the tropics, but equipped with a knowledge of the most recent 
methods of research, - a potential investigator and discoverer of new facts.

A recent report shows that the number of students is steadily increasing, and that the individual students stop longer. Six weeks to a month was at first considered sufficient; now three months is the rule, and as this period also is found to be too short, advanced courses have become necessary. These advanced courses are conducted in medical zoology, in protozoology, in arthropodology, and in helminthology. Like other parts of the course these are open to veterinary surgeons as well as to medical men.

I deal elsewhere more fully with the importance of the study of tropical veterinary medicine; it must suffice here to mention that shortly after the establishment of the School, reciprocal arrangements were made with the Royal Veterinary College to enable officers likely to be stationed abroad to study the tropical diseases of animals, and to give veterinary officers a like opportunity to make themselves acquainted with the most important human diseases peculiar to the tropics. In 1904 the Royal Veterinary College established a post-graduate course in veterinary pathology and bacteriology. These courses, open only to qualified veterinary surgeons and medical men, are essentially practical, the object being to afford to each member of the class the technical skill necessary to apply bacteriological knowledge in the investigation, diagnosis, and treatment of the microparasitic diseases of the domesticated animals, and in meat inspection. The instruction includes the pathology of the principal diseases affecting animals in the tropics. 


\section{THE BROAD STONE OF EMPIRE}

Since the School was opened in October, 1899 , nearly 1000 students have received instruction there, including medical officers of the Army and Navy, the Colonial and Foreign Office Services, missionary societies, railway, trading, and mining corporations, private practitioners and members of foreign government services and universities. Through the influence of past students, and in other ways, the School has become a centre for persons interested in tropical diseases. Trading and other corporations apply to it for advice on matters affecting the health of their employees, and are glad to select their medical officers from among the students.

While practical teaching has been the principal aim of the School, the work of research has not been neglected, and some account of the results will be found further on.

The importance of tropical medicine and the work done by the School has had the result that it has been admitted by the Senate as a School of the University of London. Tropical medicine is now accepted as an alternative for the degree of M.D. of the University, and special facilities are afforded for candidates who desire to take the degree in this subject. The School course is also recognised by the University of Cambridge for their diploma of Tropical Medicine and Hygiene.

The sphere of usefulness of the School has been extended by the establishment of what may be called associated or affiliated agencies. To Sir Frank Swettenham, late Governor of the Straits Settlements, belongs mainly the credit of opening a very 
complete laboratory for research at Kuala Lumpur in the Federated Malay States. It was arranged that the medical superintendent and tutor of the London School and the director of the Kuala Lumpur Institution should replace each other during alternate periods of about three years. It was hoped that this interchange of duties and spheres of experience would be of advantage alike in the school of education and the field of research.

Before long, bacteriological laboratories were opened in Ceylon, Singapore, Hong Kong, Mauritius, the eastern colonies, and later on, in the West Indies and in tropical Africa, and it is anticipated that all important colonies, or groups of colonies, will be provided with laboratories for the continuous carrying on of research. It will certainly be of advantage that all such institutions should be linked together by some chain of association, and it has been suggested that an arrangement may be arrived at by which experts, after studying the diseases of a particular area or group of our tropical colonies, may return to take a spell of work in the United Kingdom, and then go out again to study the diseases of a fresh area or group of colonies. The result would be a body of trained investigators, constantly abreast of the latest developments of European thought and discovery, and at the same time possessing exceptional experience of special diseases.

\section{The Liverpool School}

What the London School owes to the Seamen's Hospital Society the Liverpool School owes to the merchants of Liverpool interested in tropical trade; 


\section{THE BROAD STONE OF EMPIRE}

and what the London School owes to Sir Patrick Manson the Liverpool School owes to Major Ronald Ross, of whom it has been justly remarked that the prestige of his fame would be enough to secure a first place in the world to any school in which he is a teacher. In a report on Malaria in Cyprus, published a few years ago, Dr. Williamson acknowledged his obligations to Major Ross and to the School in grateful terms :

"At the outset, I wish to confess that such knowledge as I possess with regard to the methods of examination and observation required for malarial fever, I owe entirely to the clear, profound and eminently practical teaching at the Liverpool School of Tropical Medicine, and at the Royal Southern Hospital, of Major Ronald Ross, F.R.S., whose name is familiar to students of malarial fever throughout the whole world in consequence of his brilliant researches, which were the means of removing from the category of theory to that of fact the suggestion of Sir Patrick Manson that the mosquito played the active part in the transference of the disease."

To this testimony addition would be superfluous as regards the value of the teaching; and as regards its range I need only say that it covers all the ground included within the area of work of the London School. In the matter of accommodation, laboratories, and apparatus, the School has been magnificently endowed through the liberality of Sir Alfred Jones and other benefactors. The new buildings, opened in May, I903, contain the laboratories of the Institute of Comparative Pathology, of the School 
of Tropical Medicine, of Bio-chemistry, and of the Cancer Research Committee. The association of these departments brought together in the ThompsonYates and Johnston laboratories is of mutual aid and secures advantages alike for many-sided teaching and for research. The teaching work of the school is carried out in the most favourable circumstances, and some hundreds of students have been trained, including officers of the Colonial Medical Service, the Indian Medical Service, French Army Medical Service, French Maritime Service, Congo Free State Medical Service, and doctors and missionaries from countries as far apart as the Republic of Columbia and the Steppes of Thibet. The School is incorporated with the new University of Liverpool, which gives a diploma in tropical medicine. I may add that, to extend as far as possible the practical uses of the School, arrangements have been made for the delivery of elementary lectures on tropical diseases and sanitation to employés of the firms in Liverpool proceeding to the tropics.

But with all the advantages it offers for the teaching of students, the Liverpool School has looked upon research, and the encouragement of sanitation in the tropics based on the discoveries of research, as its principal work.

From the outset it was determined to send out properly educated and suitable men equipped with the necessary appliances to study the health and sanitation of tropical climates on the spot; and, so to speak, to fight the foe in its own haunts. In accordance with this plan of campaign many expeditions have been despatched, and numerous memoirs published 


\section{THE BROAD STONE OF EMPIRE}

dealing very exhaustively with malaria, sanitation, yellow fever, and trypanosomiasis. A large number of young medical men have carried on research work in connection with the School, most of whom have taken part in the expeditions named, while some have lost their lives in the enterprise.

Allusion has been made to the association of the London Tropical School of Medicine with the Royal Veterinary College. The national importance of the study of tropical veterinary medicine has also been recognised by the Liverpool School, and has led the University to open a department in that branch of study. The objects are, to train veterinary and medical men in the special subject of tropical diseases of animals, to afford facilities for research in these diseases, and to organise expeditions for this purpose, and to undertake preventive measures in tropical countries.

I shall emphasise, in another chapter, the necessity for extending the study of tropical medicine to the diseases that attack animals by an account of my own experience in Mauritius at the time of a devastating outbreak of surra. That calamity was the text of a remarkable speech by the late Professor Nocard, of Paris, at the opening of the Johnston laboratories in May, 1903. While warmly approving the work carried on in Liverpool, he drew attention to the great national want of systematic training and research in tropical veterinary medicine; and his speech confirmed the resolution of the University to establish a department in that special subject in association with the Institute of Comparative Pathology. The advantages offered by Liverpool 
for the study of tropical medicine are equally applicable to tropical veterinary medicine, an immense foreign cattle trade being carried on with the port. Suitable accommodation for animals is provided, and a farm station, belonging to the Institute, is easily accessible.

In addition to the advanced course of instruction for students who possess a registrable qualification to practise in veterinary medicine, the University, having received authority from the Home Office to teach students from the veterinary profession, has now opened a complete veterinary school.

These imperial services were undertaken by the University in the legitimate hope that the study of tropical veterinary medicine would receive from the Colonial, Foreign, and India Offices, as well as from the Admiralty and War Office, the same encouragement as was given to the Schools of Tropical Medicine, and that a certificate of qualification would be made obligatory for all veterinary appointments in the public service in the tropics.

\section{Medical Schools of the United Kingdom}

I have already referred to a letter addressed by Mr. Chamberlain to the leading medical schools of the United Kingdom urging the importance of encouraging the study of tropical medicine. The correspondence which followed showed that a wide interest was taken in the subject, and many gratifying proofs of the desire of important medical schools to promote the study of this branch of medicine have since been given. A measure of far-reaching promise was adopted by the 


\section{THE BROAD STONE OF EMPIRE}

University of Cambridge in instituting an examination for a diploma in tropical medicine and hygiene. The experiment has been justified; and the number of those who have been found qualified on the completion of their course of study gives assurance that the standard of study is of a high character. The value of the diploma has been increased accordingly.

Among the conditions for admission to this examination, it is provided that the candidate must produce evidence that he has studied pathology in relation to tropical diseases, clinical medicine and surgery at a hospital for tropical diseases, and hygiene and methods of sanitation applicable to tropical colonies. This regulation of the University can hardly fail to increase largely the work and the usefulness of the London and Liverpool Schools.

The importance of the study of tropical medicine has long been appreciated in Scotland. As far back as 1886 Dr. Felkin established in the extra-mural school of Edinburgh a course of lectures on diseases of the tropics and climatology. It is claimed on behalf of Edinburgh that this was the first regular course of lectures of the kind delivered at any medical school in Europe or America. Dr. Felkin's name, therefore, certainly deserves record as a pioneer in this field of work. Following Dr. Felkin's retirement, the course was continued by Dr. Andrew Davidson, a master of the subject, who, after long tropical experience in Madagascar and Mauritius, was in 1897 appointed medical adviser in Scotland to the Colonial and Foreign 
Offices. In February, I 899, the University of Edinburgh established a lectureship in diseases of tropical climates, and provided for a concurrent course of practical instruction in the parasitology and bacteriology of tropical diseases. The subject has since undergone considerable development, and at the present time four courses of instruction are given. Dr. Carnegie Dickson gives a course of instruction in practical bacteriology and the parasites of tropical diseases, Major D. G. Marshall, I.M.S., lectures on the diseases of tropical climates, Prof. Hunter Stewart and Dr. J. Buchanan Young on tropical hygiene, while Dr. J. H. Ashworth lectures on medical entomology and protozoology. Students attending these classes are granted a certificate in diseases of tropical climates, or, after having also obtained clinical instruction in tropical diseases, may present themselves for the University's diploma in tropical medicine and hygiene, which is especially intended for those who desire posts in tropical colonies and dependencies. In April, I909, three of these diplomas were conferred, while the number of students attending the classes has shown a steady and gratifying increase.

In I 899 a lectureship, on much the same lines as have been followed in Edinburgh, was founded in Aberdeen, Dr. G. A. Maconachie, who had for twenty-five years been connected with the Grant Medical College of Bombay, being selected as lecturer. This lectureship was temporary, but a permanent one is to be established as soon as funds permit. 
Edinburgh and Aberdeen claim to educate a class of students furnishing a larger proportion than any other University of the men who do the work of the Empire, and certainly not a few of their alumni hold important appointments in India and in the colonies. This may to some extent account for the zeal with which education in tropical pathology is being prosecuted within a few degrees of the Arctic circle. $\mathrm{Be}$ this as it may, I believe I am justified in saying that the prosecution of the study of tropical medicine in Scotland received its most powerful impetus from Mr. Chamberlain's encouragement.

It must be recorded that Mr. Chamberlain's action in 1898 was immediately followed by a resolution of the Court of Queen's College, Belfast, " to establish, subject to the sanction of the Lord-Lieutenant, a lectureship in the College in tropical medicine, in accordance with the suggestion of the Secretary for the Colonies," but the scope of my work prevents me from including an account of the progress of tropical studies at the medical schools of St. George's, Charing Cross, The Royal Free, St. Thomas's, and The London hospitals and other medical schools in the United Kingdom.

IV

\section{RESULTS OBTAINED}

It has been noted that the London and Liverpool Schools have devoted much time to research work in addition to teaching. It may be convenient to sum up here briefly the more important results obtained by the workers of these Schools, and by investigators 
trained by them or more or less directly inspired by their work, and by others. These results are most conveniently summarised under the headings of the diseases to which they refer.

Malaria. The Liverpool School was founded shortly after Major Ross had discovered in India the part played by the mosquito in the propagation of malaria, and it was determined at once to follow up his work in West Africa. In the autumn of I 899 Major Ross, accompanied by Dr. Annett and Mr. Austen, of the British Museum, proceeded to Sierra Leone, where they discovered the malaria-bearing species of mosquito, and determined the fundamental principles on which the prevention of malaria should be conducted. To carry on the work an expedition was despatched to the Gold Coast and Lagos in the winter of 1899 , followed in the spring of 1900 by another to Northern and Southern Nigeria. In May, I901, a donation of $£ 2,000$ was given by a supporter of the School to enable practical measures to be taken against malaria by an organised campaign against mosquitoes. Operations were conducted by Major Ross, who, in June, I90 I, accompanied by Dr. Logan Taylor, set out on an expedition to Sierra Leone for the purpose of making extensive experiments as to the best method of dealing with mosquitoes in tropical towns. The expedition, one of the most important organised by the Liverpool School, extended over two years, and included subsidiary expeditions to the Gold Coast and Lagos. The value of the work accomplished by these expeditions to the colonies of the 


\section{THE BROAD STONE OF EMPIRE}

west coast of Africa and Nigeria has been confirmed by the abundant testimony of experience. Recently, Dr. Johnston, who has had thirty years' experience in Jamaica, visited the Liverpool School on purpose to bear testimony to the value of the teaching of the School in regard to the prevention of malaria. He had at first thought that the destruction of the mosquito was a hopeless task, but a very large and practical experience, chiefly among the natives, had convinced him of the efficacy and practicability of the measures put forward by Ross and his School. In his own experience these measures have reduced the mortality among the native soldiers of the West Indian regiments serving on the west coast of Africa some seventy-five per cent. The preventive measures have proved not only of use to white trading officials and officers, but also of immense advantage to the natives themselves.

In 1902 Prince d'Arenberg, chairman of the Suez Canal Company, made a special request for the services of Major Ross to proceed to Ismailia, and advise on a method to rid the town of mosquitoes, and so arrest the very serious sickness and mortality from malarial fever. The Committee willingly assented to this request, and Major Ross left for Ismailia in September, accompanied by Sir William MacGregor, who wished to investigate the malaria problem on his own account. Major Ross's report, including measures proposed for the antimalarial sanitation of Ismailia, Suez, and Port Said, was published by the University Press early in I903. In I904 Professor (now Sir Rubert) Boyce, F.R.S., Dean of the Liverpool School, was invited 
by Prince d'Arenberg to visit Ismailia and see for himself the work carried out by the Company on the advice of Major Ross. An interesting account of Professor Boyce's visit was published by the University under the title Anti-Malaria Measures in Ismailia. Of the result of the experiment he said:

"The anti-malarial experiment undertaken by a great business company, minutely watched by numerous officials, and with most carefully-kept statistics, affords the most convincing proof of the feasibility and commercial advantages of welldirected anti-malarial sanitation that has yet been seen. To Egypt it adds another to its long list of successful enterprises, and it is an example to all our malaria-plagued towns in West Africa, India and elsewhere. It will do more than any other experiment to remove the scepticism which has hindered the progress of this great sanitary reform as it has hindered other reforms. The Canal Company are to be congratulated upon a success only equalled by Havana, where a most vigorous anti-mosquito campaign has ended in banishing both yellow fever and malaria from what was, until recently, one of the most fever-stricken of cities."

The following figures from a lecture delivered in I 909 by Sir Rubert Boyce illustrate the significance of this statement :

Malaria at Ismailia.

$\begin{array}{lllrl}\text { I9O2 } & - & - & \text { I,55 I } & \text { cases. } \\ 1903 & - & - & 2 \text { I } 4 & , \\ 1904 & - & - & 90 \quad, \\ \text { I905 } & - & - & 37 \quad,\end{array}$




\section{THE BROAD STONE OF EMPIRE}

The anti-malarial operations began on a large scale in 1903 .

Speaking of the cost of the Ismailia work, Sir Rubert Boyce justly observed that the return is amply remunerative in the diminution of the rate of sickness, and the reduced number of the Company's servants in hospital or incapacitated from work; while the life of the Company's officials and servants is rendered more safe, and the town is made attractive as a health resort.

During the last few years much has been done in tropical sanitation against malaria on the lines laid down by Major Ross at Ismailia. These measures consist in the destruction of the breeding places of mosquitoes by surface and subsoil drainage, subsidiary measures being prophylaxis by quinine, screen, and segregation.

Major Ross believes that State intervention is necessary if the fullest results are to be obtained, and recommends the appointment of special commissioners to travel from place to place to advise local authorities as to the best measures for dealing with malaria in each locality.

Members of the London School also have done a very large amount of work in connection with malaria. In an address delivered in December, 1903, Sir Patrick Manson gave some illustrations of what had been and was being done by men from the London School. He referred in particular to an important experiment carried out by the mission of Dr. Sambon and Dr. Low to the Roman Campagna. These gentlemen, with Signor Terzi and their servants, resided for three or four months. 
during the most unhealthy season of the year, in the most unhealthy place in Europe, employing the precautions against mosquito-bites advised by the School authorities. The experiment proved that it is possible to live in an intensely malarial district without injury to health if precautions are taken against mosquito-bites. Coincidently with this experiment, infected mosquitoes were imported from Italy and set to bite individuals in the School laboratory. The persons bitten were at once infected with malarial disease, and the two experiments gave a practical and convincing demonstration of the mosquito malaria theory.

The relation of mosquitoes to malaria has since been tested on a larger scale as an economic measure, and not as an experiment, and where the anophelines have been substantially reduced, there the malaria has, as was expected, more than proportionately diminished. Two instances of such successes are worth quoting as illustrations.

In the Federated Malay States, Klang and the adjoining port, Port Swettenham, were so intensely malarious that the question of the abandonment of the port had to be considered and the cost of labour was much increased. In I90I as many as 334 patients were admitted to hospital with malaria, and only the more serious cases were admitted. Drainage, specially adapted to destroy the mosquito breeding places was carried out by the Public Works Department, under the supervision of Drs. Watson and Travers. The works were nearly completed by the end of 1902, and the admissions dropped from over 330 to an average of twenty-nine, whilst 


\section{THE BROAD STONE OF EMPIRE}

there was no diminution, but an increase, in the surrounding undrained districts. The saving in labour may be illustrated by the variations in the amount of sick-leave granted to Government employees in the two periods: in 1901, I 76 Government employees were granted altogether 1,026 days' sick-leave; in 1903 only seventy-one days' sickleave was required by 226 Government employees. The expense in this case was considerable : the port and town had to be made healthy or abandoned, and the total expenditure, including upkeep, has been over $£$ I per head of the population. But in many places marked diminution in the amount of the malaria in small stations has been effected by a combination of methods with little or no special expenditure.

What can be done for the health of Europeans in one of the most malarial parts of Africa,-the shores and islands of Lake Nyassa-is illustrated by the work of Dr. Howard, another London student.

The stations of the University Missions on that lake are very scattered. The funds available for the preservation of the health of the workers are very limited, and the amount of sickness, invaliding, and the proportion of deaths have been large. During the five years I895-1900 inclusive, the average number of European workers was 24.4 per annum; seven of these died, and eight were invalided. Dr. Howard, adopting different measures in accordance with differences in the stations, commenced active work in 1900, and in 1901-1905 the average annual number of workers was increased to thirty-six, that is, by nearly one-third; but as there were only two 
deaths and four invalided, the mortality was reduced to less than one-fourth and the invaliding rate to less than half.

Under the heading of results, we may also consider the scientific inquiry into malaria conducted by a commission acting under the guidance of the Royal Society. The members of the commission were Dr. Daniels, now Director of the London School of Tropical Medicine, appointed by Mr. Chamberlain, and Drs. Stephens and Christopher, nominated by the Royal Society. The results of their work were published by the society in a series of reports; and in April, 1903, Sir Michael Foster communicated to the Colonial Office a brief review of the work accomplished by the Commission.

The researches of the Commission were carried on in British Central Africa, on the West Coast of Africa, in Bengal, and in the Punjab. They confirmed in every particular the facts and conclusions of Major Ross's mosquito work. On a complete investigation of the various species of mosquitoes carrying the malaria parasite and acting as agents of infection, in the course of which they added to our knowledge some important discoveries in respect of the agency of the native community in the infection of Europeans, they made recommendations of great practical value for the prophylaxis and treatment of malaria.

It had been an instruction to the Commission to study not only ordinary malaria in its various forms, but also the disease known as blackwater fever, the cause and nature of which had long been in dispute, some observers maintaining that it was a form of 


\section{THE BROAD STONE OF EMPIRE}

malaria, others that it had no connection with that disease, or was at any rate due to a different parasite. The Commissioners, considering the fatality of this fever and the fear it inspires in Africa, fully realised the importance of trying to solve the question of its cause and nature. On the basis of direct microscopical evidence, confirmed by facts established to their satisfaction, they came to the conclusion that the disease is essentially of malarial origin. It followed, and this was a matter of great interest, that the prophylaxis is in the main identical with that of malaria, and consequently that the European who can protect himself against malaria need have no fear of blackwater fever.

Among other successful campaigns, the case of Hong Kong may be specially noticed. In Hong Kong there are a large white population, a heavy rainfall, and many breeding places for anophelines. Operations were commenced by Dr. Thomson in I9OI. In that year I,294 cases of malaria were admitted to the two principal Hospitals, and there were 132 deaths. In 1905 the admissions had fallen to 4 I 9 , the deaths to fifty-four.

In many other parts of the world successful campaigns against malaria have been carried on. Thus in Greece the Grecian League against malaria has obtained wonderful results in the plain of Marathon, formerly a hotbed of fever. In 1906 ninety per cent. of the cases of sickness in this plain were due to malaria, in 1907 , after the first efforts of the League, the malaria cases fell to forty-seven per cent. of all cases of sickness. During the summer of 1908 , summer being usually the most intensely malarious 
season, the sickness due to malaria fell to two per cent. of the total cases of sickness.

Yellow Fever. In the year 1900 an expedition, consisting of Dr. H. L. Durham and Dr. Walter Myers, was sent from the Liverpool School to Brazil to study yellow fever on the Amazon. Proceeding to Brazil, through the United States of America, the expedition joined, for a short time, the official Yellow Fever Commission of the United States Government in Cuba. The death of Dr. Myers from yellow fever on this expedition was commemorated by the establishment of a lectureship and a fellowship, both named after him, and having for their object the encouragement of research in tropical medicine. The parasite of yellow fever has not yet been isolated, but it is known to be conveyed by a mosquito belonging to the genus Stegomyia. The steps taken to eradicate the disease consist in the destruction of Stegomyia calopus in the houses, prevention of their breeding in the water cisterns, and the early recognition and screening off of yellow fever patients, with the fumigation of all infected houses to destroy mosquitoes.

Very successful campaigns against yellow fever have been carried out by the United States Government in Havana, Panama, and New Orleans. Other campaigns have been carried out with great success in Rio de Janeiro and also in British Honduras.

In an earlier chapter I have spoken of the influence of health and sanitation on the character of the people of the United Kingdom during the earlier decades of the nineteenth century. A recent 


\section{THE BROAD STONE OF EMPIRE}

writer, Mr. C. F. G. Masterman, in a work entitled The Condition of England, dealing with the same subject at the present day, has incidentally exhibited a graphic picture of the influence of these campaigns in Central and Southern America. "Panama," he says, "in the early days of the Canal building, was converted into a visible hell, in which a population rioted and rotted and died, as they rioted and rotted and died in the days of the plague. The Americans to-day have descended there with all scientific resources. They burn the insect, they choke its offspring with oil, they drain the stagnant pools where it can breed, they consume it in clouds of evil-smelling smoke. They are rapidly making Panama a healthier place than New York or Chicago. All down the coast of South America, yellow fever has decimated mankind for centuries. To-day it is well on its way to becoming a thing of the past."

Trypanosomiasis. Sir Patrick Manson claims that the world is mainly indebted to the London School of Tropical Medicine for the discovery that a parasite of the group known as Trypanosoma is the cause of sleeping sickness, one of the most terrible diseases to which tropical humanity is liable. The association of this parasite with the disease was first demonstrated by Dr. Castellani, a pupil of the School, and it formed the subject of an exhaustive investigation by a Commission of the Royal Society under Sir David Bruce, R.A.M.C., sent to study the disease in the Uganda Protectorate. The parasite was actually found by $\mathrm{Dr}$. Forde in a 
patient in the Gambia, and identified by the late Dr. Dutton of the Liverpool School. The patient died subsequently in Liverpool with cerebral symptoms.

The investigations of Professor Koch on the Victoria Nyanza seem to indicate that in atoxyl we have a valuable drug both as a curative agency and for the alleviation of suffering in the last stages of the complaint. Prophylactic measures are also being carried out, which appear to have checked the progress of the disease in Uganda, but it is yet too soon to give a definite opinion of their results. Thus, though the disease continues to claim its thousands of victims annually, much work has been done and considerable progress made in the elucidation of the complex problems associated with its etiology, mode of transmission, and treatment. The further study of the disease has been assigned to a special department of research which will be referred to later.

Trypanosome parasites are not only associated with disease in man, but also with some of the deadliest forms of disease to which domesticated animals are liable in the tropics, notably the epizooty known as surra. In 1902 the Liverpool School of Tropical Medicine despatched an expedition under Drs. Dutton and Todd to the Gambia and French Senegal to prosecute the study of trypanosomiasis in man and animals. In September, I903, on the representation of the King of the Belgians, who made a handsome donation for the purpose, a further expedition was despatched to the Congo. On these investigations the School has 


\section{THE BROAD STONE OF EMPIRE}

expended several thousand pounds, and appeals for further funds to carry on the work.

Beri-Beri. The name at least of this disease, one of the most mysterious with which medical science has had to deal, became familiar in England in connection with the introduction of Chinese labour into the Transvaal. The investigation of beri-beri has been actively prosecuted at the London School, which has the advantage of access to the many cases of the disease brought to the Port of London from the East.

Beri-beri was the subject of an exhaustive report by the Surgeon-General of the United States Army in 1903, showing that the disease was a very decided factor in the morbidity and mortality among the Malay troops of the United States in the Philippines. The report was of importance as exhibiting the results of practical experience of the operation of the disease among native troops commanded by white men, and living under a system of organisation designed by the intelligence of Western civilisation. It had, therefore, a practical bearing on the general question of the migration of Malay labour, and on specific questions arising out of the introduction of Chinese into South Africa.

Much excellent work has been done by Dr. Durham, who was sent on a mission to study the disease, and who had quite exceptional opportunities for its investigation in the Federated Malay States, where it is rampant. The disease is alarmingly prevalent in Hong Kong, and attended by a high mortality, and it is reported to occur in Uganda under the name 
of bitimbo. The question of its etiology is still a subject of much discussion. The careful experiments carried out by Messrs. W. Koch and Hunter of Hong Kong, though they throw little direct light on our knowledge of beri-beri, appear to have narrowed down the inquiry by eliminating one at least of many hypotheses. Their researches would seem to show the non-bacteriaemic nature of the disease, the impossibility of conveying beri-beri from man to animals, and that it is not infectious in the strict sense of the term. The environment, food, and habits of the coolie class, amongst whom it prevails, predispose to the disease, and the most recent work points to its being due to certain samples of rice prepared in a special way. These results are already being put into practice by planters and others, and there is good hope that by this inexpensive change in the dietary, one of the great disadvantages of working in the East will be overcome.

Malta Fever. The remarkable work done by Sir David Bruce in tracing this disease to the use of goats' milk has been already referred to. The subject is still under inquiry in its general bearing on the use of goats' milk in other parts of the world.

Minor Diseases. Amongst other important advances is the discovery of the cause of the tick fever in Africa, which was shown by Dr. Philip Ross, of the London School, to be due to a Spirochaeta, and to be closely related to relapsing or famine fever, once common in Europe and still common in India. 


\section{THE BROAD STONE OF EMPIRE}

Each year more attention is being paid to diseases that have been long known, but in few places have been actively combated. Amongst these is Ankylostomiasis, an intestinal worm-disease fatally dangerous to labour, and especially to imported labour. Twenty years ago Ceylon and Fiji were the only British colonies that took any steps at all to combat this disease, though in some, as in British Guiana, the worm had been discovered more than sixty years ago (1847) and rediscovered in the early eighties. For many years after, though much was done in the way of treatment of those affected, no organised effort had been made to prevent or diminish the occurrence of the disease.

To Sir Patrick Manson is due the discovery that Filaria noctuma, the parasite of a large class of tropical diseases, is transmitted by the agency of a mosquito. This discovery indicates the way by which elephantiasis and an important group of kindred diseases may be avoided.

Much has been done to aid the rank and file of tropical workers, to confirm and extend the results obtained by others, and, generally speaking, to advance our knowledge and place it on a sounder and more scientific basis. Of direct practical utility was the advance made by Dr. Leiper, of the London School, in showing that the guinea worm embryos, which had been long known to undergo development in a small fresh-water crustacean, passed into the human body by the mouth, and that infection occurred by persons swallowing water from a source in which others had bathed. 
COLONIAL MEDICAL REPORTS

The collection and publication of reliable annual records of work and research carried on by colonial medical officers on the lines recommended by Sir C. Gage-Brown's Committee has borne good fruit. These records contain exact statistics and reports of carefully conducted experiments and observations from our tropical possessions, and thus enable scientists all over the world to obtain a full knowledge of every disease that has come under observation. They furnish, moreover, abundant evidences of the impetus given to the local study of endemic and epidemic diseases by Mr. Chamberlain's administration; while some of the later reports, to one of which reference has already been made, supply gratifying proof of the extent to which the capacity for investigation has been developed by the teaching of the schools of tropical medicine.

While adding a substantial record of facts to our knowledge of those tropical diseases which have been, during the last few years, principally engaging attention under the names of malaria, filariasis, yellow fever, and beri-beri, the reports deal with the diseases of less widespread prevalence and notoriety, but which are among the most formidable of local scourges, such as yaws. And many of the reports deal with a disease not peculiar to, but of extensive prevalence in, the tropics,-syphilis. These reports present some startling facts regarding the causation and consequences of the disease, and the condition of social life in communities in which it is most prevalent. 


\section{TROPICAL DISEASES RESEARCH FUND}

In transmitting the report of the Sleeping Sickness Commission of the Royal Society to the Foreign Office, Sir Michael Foster pointed out that, while the study of sleeping sickness had been the definite object of the Commission, it had brought to light the widespread existence in Uganda of actual or potential causes of diseases in man and animals in the form of parasitic organisms. And as diseases due to similar causes were prevalent not only in Uganda and in the protectorates at that time administered by the Foreign Office, but also in many of the colonies, he urged the importance, in the interests of the Empire, of a well-organised and adequate investigation of these diseases.

Sir Michael Foster had already addressed to the Colonial Office a similar expression of advice with reference to the work of the Royal Society Malaria Commission and other measures taken on Mr. Chamberlain's initiative for the prevention of malaria. It was suggested that the organisation carried out with such valuable results by Mr. Chamberlain, might with great benefit to the Empire be expanded into some larger scheme. After pointing out that the success of such a scheme would depend on a large expenditure, in order to secure the services of investigators of proved experience and ability, equipped with the very best appliances of modern inquiry, he concluded by saying that the scheme which he had in his mind, put broadly, comprised the following points.

(1) The formation of a fund large enough to 
cover the estimated expenditure, the fund being of an Imperial character, shared by more than one department, and contributed to by various parts of the Empire.

(2) The administration of this fund by an authorised body.

(3) The expenditure of this fund partly and chiefly in inquiries conducted in the localities where the diseases occur, by special investigators sent out for the purpose, or otherwise, but also in part in the maintenance of an establishment at home, in which inquiries begun in the fields of the diseases could be more conveniently and effectively completed. It might be desirable to have similar establishments in other places besides England.

Sir Michael Foster's proposal was communicated by Mr. Chamberlain to the Foreign Office and India Office, as well as to the Crown colonies and protectorates. The proposed fund was ultimately established as the Tropical Diseases Research Fund, and Mr. Chamberlain's successor, Mr. Lyttelton, established in 1904 a Committee of the Colonial Office to advise on its administration.

The appointment of this advisory Committee has been followed by the establishment of a Sleeping Sickness Bureau in London for the collection and distribution of information regarding that disease, accommodation for the Bureau having been provided by the Royal Society at Burlington House. The publications of the Bureau will be divided into two categories; scientific publications for those engaged in research, and popular publications for 


\section{THE BROAD STONE OF EMPIRE}

the use of Government officials, missionaries, and others whose duties involve residence in areas subject to the disease. The Bureau is now engaged in the preparation of a map of tropical Africa showing the distribution of the disease and of the different species of insect suspected of conveying it.

THE GENERAL MEDICAL COUNCIL

\section{An Imperial Pharmacopoia}

I have little to add to what has been said on the subject of the revision of the Pharmacopœia of 1898 and the Indian and Colonial Addendum, I900. The Committee appointed by the General Medical Council to undertake the revision are prosecuting their labours.

The Colonial Office has been taking steps to secure the systematic examination by local experts of the paragraphs of the Addendum of 1900 relating to the various colonies, and the Committee invite and welcome criticisms and suggestions from beyond the seas; but the collation of the reports, the work of retesting statements and figures, and research on doubtful points require time.

In November, I906, the General Medical Council referred to the Committee a report containing various recommendations respecting published criticisms of the Pharmacopœia of i 898 . The Committee has held many meetings and presented interim reports explanatory of the work already accomplished on general principles laid down in 1907. Some idea of the magnitude and importance of this work may be gathered from the fact that the 
Committee has had to deal with analyses of upwards of 43,000 prescriptions of medicines, official and non-official (including proprietary), used in Great Britain and Ireland.

In October, 1909, the Committee had under consideration a digest of proposals for inclusion or omission of drugs and preparations, but points were raised and discussed which have made it necessary to postpone a final revision. As regards the Indian and Colonial Addendum of 1900, the Committee has been constantly receiving and is still receiving through the India and Colonial Offices information regarding indigenous drugs. It may still be some years before a revised edition of the Pharmacopœia of 1898 is followed by a revised edition of the Indian and Colonial Addendum.

THE COLONIAL NURSING ASSOCIATION

While Mrs. Chamberlain has not ceased to take an active interest in the Nursing Association, she has, to the great advantage of our Colonial Empire, found able and willing coadjutors, who form a large Council and Executive Committee under the presidency of Lord Ampthill. The Association has now a useful auxiliary in its Scottish branch, of which Lady Balfour of Burleigh is President, supported by a distinguished and influential Council.

The work of the Association has been carried on with great success by the sub-committees of the Executive Committee, the Council devoting itself to larger questions of principle and administration. The sub-committees are styled the General Purposes 


\section{THE BROAD STONE OF EMPIRE}

Committee, the Nursing Committee, and the Sick Pay Fund Committee.

Local branches are established in the colonies to undertake the supervision and care of the nurses, to raise funds, and to control the local expenditure. The arrangements between the Association and the local committees vary in different colonies. The general principle is the encouragement of local self-help, grants-in-aid being made only when the Association is satisfied that the local committee has done all that is possible, in the circumstances of the community, to meet its requirements. Accordingly, it is a first and principal duty of the local committees to fix a tariff of remuneration for the services of nurses such as, supplemented by local subscriptions and donations, will make the work self-supporting. In the Crown colonies generally the European community is limited to Government officials and the managers and employees of commercial and agricultural enterprises. In these communities such a tariff as would suffice to cover all expenses incidental to the supply of nurses would easily be within reach of the heads of departments, the principals of commercial firms, and the owners or managers of estates; but it would generally be prohibitive in the case of subordinate officials and employés, a class which it is the earnest desire of the Association to assist. When, therefore, the real need of assistance is proved a grant-in-aid is allowed. Sometimes the Association pays the cost of the nurse's passage, or advances the necessary amount, to be subsequently repaid, on the local committee undertaking to find the cost of main- 
tenance and other incidental expenses; sometimes it agrees to defray all charges except the cost of maintenance; at others it pledges itself to make good, within certain limits, any deficit that may occur in the transactions of the local committee.

The principal business of the Nursing Committee is the selection of nurses, - a difficult and responsible duty; for it must be remembered that the conditions of life vary widely in the different colonies, and that they have only this in common, that all present to an English nurse an environment of persons and things absolutely foreign to her previous associations and experience. Thus it may well happen that a nurse who has been exceptionally successful in one colony may prove a failure in another. And while a successful nurse easily wins the gratitude of a community and thus secures their generous co-operation in promoting the objects of the Association, a failure, from whatever cause, is a sore and a lasting discouragement. When a candidate for an appointment as nurse has satisfied the Committee, in respect of professional qualification and personal character, every endeavour is made to enable her to understand the climate and conditions of life in the colony to which it is proposed to send her; and with this object, whenever possible, a lady from the colony who may happen to be in England is invited to be present at an interview with the nurse. In the case of nurses resident in Scotland, interviews are arranged and recommendations made by the Scottish branch of the Association. Before an appointment is finally made, the candidate has to be examined by a medical officer of experience in 
tropical climates, as to her physical fitness for service in the colony to which she is designated.

The Association has entered into an arrangement with the Tropical Schools of Medicine of London and Liverpool to enable a certain number of their nurses to have a short course of special instruction, and preference is given to candidates thus qualified. It is the intention, so far as possible, to send to the more dangerous climates only those who have had the advantage of this experience.

Although the main object of the Association has been from the first to supply trained nurses for private employment in the Crown colonies and British communities abroad, it has gladly consented to select nurses for Government hospitals and Government appointments in the colonies. These appointments are made by the Secretary of State, but through the agency of the Association the Colonial Office is relieved of a task which can be much more suitably carried out by the Nursing Committee.

From I 897 to 1909 the Association sent out 467 nurses. As they go out under agreements, varying from two to five years, the number employed in any one year varies. The total number at work during the year 1909-10 was 220, of whom I5 I were employed by Government and sixty-nine as private nurses. The range of the work may be gathered from the fact that, during 1909, private nurses were employed in Bangkok, Ceylon, Costa Rica, HongKong, Japan, Lisbon, Madrid, Mauritius, Oporto, Shanghai, Singapore, South Africa, Teheran, and Tientsin, while Government nurses have been sent 
to the colonies and protectorates in East and West Africa, to British Guiana, Ceylon, Cyprus, the Falkland Islands, Gibraltar, Hong-Kong, Malta, the Straits Settlements, and the Federated Malay States, St. Helena, the West Indies, and Western Australia.

It is certain that questions of finance are of hardly less importance than the work of the General Purposes and Nursing Committees, and it is fortunate that Captain Hartley Maud has been good enough to give his services to the Association as honorary treasurer. The income of the Association is derived partly from the investment of a sum of nearly $£ 6,000$ raised by public contribution; the rest depends on annual subscriptions and donations. For the year ending March 3 Ist, 19IO, the total income amounted to only $£ 721$. This modest sum was found sufficient to enable the Association to carry on its work, and to leave a small surplus. After thirty-five years of residence in tropical colonies, and personal experience of the work of the Association's nurses from the first foundation of the Society, I gladly add my testimony to the importance of the need and the value of the services rendered. The Association has every right to claim to be a factor in the maintenance of our Colonial Empire as contributing to the health of those who administer it or promote its commercial and industrial enterprises.

I have endeavoured in the pages I now bring to a close, to give a brief account, in a way which may, I hope, appeal to popular sympathy, of the work 


\section{THE BROAD STONE OF EMPIRE}

done by the principal agencies encouraged by Mr. Chamberlain to associate themselves with the Colonial Office, in the task of promoting health, strength and efficiency in the Crown colonies and protectorates. The medical reports to which reference has been made show that in addition to the diseases principally dealt with by these agencies,malaria, filariasis, trypanosomiasis, yellow fever, beri-beri-other diseases such as cholera, bubonic plague and leprosy are of frequent occurrence. The researches into their origin, which have been carried on concurrently with those I have described, belong rather to the domain of the Government of India, but I shall have occasion to refer to some of them, more especially to the prophylaxis, treatment and consequences of bubonic plague, in a narrative of my personal experience, which will form the subject of the next chapter.

Of Mr. Chamberlain's work it may be said, in brief, that on his initiative or with his encouragement the attention of the Empire was directed to the study of tropical diseases; research expeditions were sent abroad; the cause and nature of diseases that have long ravaged the tropical world were discovered, and the means of prevention investigated; new diseases affecting men and the lower animals in new spheres of our Empire have been brought to light and studied with a view to prevention and cure. Already the result of these researches has been an appreciable addition to the security of life and the comfort not only of British subjects engaged in the work of administration or in commercial and industrial enterprises, but of multitudes 
of natives. And to secure uninterrupted continuity in the work of research, medical men have been trained in schools which have served as models for other nations and have been taken advantage of by students from many parts of the world. 


\title{
CHAPTER XIII
}

\author{
HEALTH
}

II

PERSONAL EXPERIENCES OF TROPICAL DISEASES

I HAvE lived for over thirty-five years in an environment of tropical disease. My first colonial experience was in Mauritius in the year r868. An epidemic of malarial fever of exceptional fatality had broken out in $\mathrm{s} 866$, and was still raging. $\mathrm{Up}$ to the time of this epidemic Mauritius had been one of the healthiest colonies of the Empire; as a naval and military station it was of unsurpassed salubrity; it was also a favourite health resort for Indian civilians on furlough, while commercial and agricultural enterprises were carried on amid surroundings which seemed to combine every charm of the tropics with the most favourable conditions of life in temperate climates. The centre of business and of pleasure was Port Louis, where also were the military headquarters. It was here that the fever commenced. Slowly, but constantly, it encroached on the suburban districts and on the line of sea level around the coast. As it advanced the residences of the wealthier 
society were removed to a higher elevation. The barracks at Port Louis were first abandoned, and subsequently, as the fever advanced along the coast, other military posts. In illustration of the gradual progress of the malarial area, I may mention that in I 870 the Government commenced the erection of an observatory at great cost. The site, in the district of Pamplemousses, not much above sea level, has since become so unhealthy that the Government has been urged to abandon it. In the hope that this necessity may be avoided, every measure of antimalarial sanitation advised by Sir Patrick Manson and the schools of tropical medicine has been adopted. In ISSO it was thought that settlements at a height of 700 or Soo feet above sea level were safe from malarial influences, and the Government undertook the erection of a large and costly central prison at Beau Bassin, in the district of Plaines Wilhelms, then a favourite centre of society. Before many years had passed the unhealthiness of this prison caused grave anxiety, malarial fever having invaded the district with such intensity that military officers were no longer allowed to reside within it. In I 896, at a time when it was determined to make Mauritius a great naval and military base, a vast permanent camp, equipped for a large garrison of British and Indian troops, was established at an elevation of from I,200 to I,400 feet in the same district. But an epidemic of fever in I9oo showed that it was not beyond the range of malarial influence. The census of the following year gave striking proof of the operation of five and thirty years of this influence. It was 


\section{THE BROAD STONE OF EMPIRE}

found that the population of Port Louis had decreased from 74,420 , at the census of 186 I, to 52,740 ; while the population of the district of Plaines Wilhelms, to which the refugees had resorted, had increased from 28,020 to 63,624 . I shall have to deal fully with the epidemic of 1900; for the present I need only observe that the epidemic of 1866 had its origin in the introduction of the malaria-bearing mosquito by immigrants from India. It was a typical illustration of the distribution of tropical disease from centres of origin following the migration of labour. Had all that recent research has discovered been at the time within the range of medical knowledge, there seems to be little reason to doubt that measures of prophylaxis and treatment would have been at once adopted which would have arrested the epidemic, and saved the colony from the consequences I have indicated,-an enormous mortality, an endemic disease, a vast depreciation of property, and the displacement of the homes of a large section of the community.

To revert to my personal experiences in sequence of time. In I 875 I suffered so severely from the effects of malaria that Dr. Charles Murchison, a physician of celebrity in the treatment of tropical diseases, as then understood, urged me to abandon my colonial career, as many of my contemporaries and colleagues had been forced to do. The experience was not without value to me in the work it has since been given me to accomplish. In 1878 my services were transferred to Ceylon, and my appointment as Director of Public Instruction gave me exceptional facilities for visiting 
outlying districts and making myself acquainted with the condition of the people. In many parts of Ceylon, as in the tropics generally, epidemic and endemic diseases have a great influence on school attendance; and this was strikingly illustrated in the North Central Province, where schools were few and very far between. They were also difficult of access; and in this way it happened that a school, established in a village known by the ominous designation of Fever Village, escaped a visit from the department for some years. An inspector sent with special instructions to visit the school found it, with some difficulty, seventy miles from the site where it had been established. The explanation was that the village, with its school, had migrated to successive locations, from each of which it had been driven by visitations of fever until it had reached the spot where it was found by the inspector. I mention this incident because it may be said to be typical of the history of the province. Historically it is the most interesting district in the colony. It contains the city of Anuradhapura, with its sacred Bo-tree, its fallen temples and palaces, the sacred rock of Mihintale, the ruined city of Pollanarruwa, and innumerable monuments of a great religious and political past. At the present day the province, once the most richly cultivated and thickly peopled part of the island, is a region of abandoned lands, the home of a sparse and anaemic population. It may never be possible to trace to its origin the cause of the desolation of this once prosperous and wealthy centre of Oriental life, but of the cause there can be no doubt. I have indicated some of the results of five 
and thirty years of malarial fever in Mauritius; the same cause operating through centuries has produced the ruin and depopulation of the North Central province of Ceylon. Since the days of Sir William Gregory, 1871-77, much has been done in the hope of restoring its prosperity. The realisation of this hope seems now to have been brought within the range of practical measures, and to await only the adoption of an appropriate system of anti-malarial sanitation. Restored to sanitary conditions such as generally prevail in the colony, in the area of European commercial and agricultural enterprises, and in the chief centres of administration, the province will probably be found to possess capabilities of development inferior to no other part of Ceylon. The recent construction of a railway through the province has been an interesting experiment. Railway construction through malarial areas in Ceylon, as elsewhere, has hitherto been accompanied by high rates of disease and mortality, and I had hoped that some statistics might have been forthcoming showing the mortality and invalidity among the engineering staff and the labourers, as compared with previous records of railway construction in the colony. I learn, however, from the Colonial Office and the general manager of the Ceylon railways, that no returns from which a reliable deduction could be drawn, have been made. While I refer particularly to the North Central province, malaria is a powerful factor in the disease and death-rate in many parts of Ceylon. Other tropical diseases being also endemic, Ceylon, although it must be counted amongst the healthiest of the tropical colonies, must 
be reckoned among those certain to derive gain from studies and discoveries in tropical medicine and hygiene.

From 1885 to 1893 I served in British Guiana. It was a period of great interest, owing mainly to the impetus given to the development of the resources of the interior, including the gold-fields. While looking back with pleasure and satisfaction to those years of my public life, my experience reminds me that there are few colonies in which administration, industry, and commerce meet graver obstacles in the various forms of tropical disease. Endemic malaria, epidemics of yellow fever, and the ever-intrusive mosquito are formidable enemies, and have to be met by strict measures of precaution. Some records of my experience of tropical disease in British Guiana will be found in other chapters of this work.

My residence in the tropics led me long ago to form a very strong opinion of the inadequacy of the Pharmacopœia to meet the requirements of our colonial empire. An incident in British Guiana tended to confirm this opinion. Early in 1889 a member of my family had a severe attack of pernicious fever. The fever having continued for several days, and extensive hæmorrhage having set in, my medical adviser, a dear friend of long colonial practice and experience, suggested, as a last resource, the calling in of a local empiric. The next day he brought with him a native lady, who at once treated the patient with herbs gathered by herself in the garden of Government House. Within three hours the fever broke, and the patient, though in a state of extreme exhaustion, was cured. This 


\section{THE BROAD STONE OF EMPIRE}

case is one among many known to myself and others who share my views; and I have naturally taken much interest in the work of a revision of the Pharmacopoia by the adoption of medical herbs and substances of proved efficacy, either in substitution of or in addition to the recognised drugs. I have never ceased to urge the importance of this subject on the Colonial Office, and I have more than once ventured to invite the cooperation of the General Medical Council. The question has been already discussed.

In I 893 I was appointed Governor of the Windward Islands, and my knowledge of tropical diseases was enlarged by my experience of the loathsome disease known as yaws, very prevalent in the islands, and especially in St. Vincent. To an outbreak of yellow fever among the sailors and garrison at St. Lucia allusion has been already made. The Island of Grenada, where the headquarters of the Government are established, is comparatively healthy.

In 1897 I returned to Mauritius as Governor, and for nearly seven anxious years had experience of visitations of malaria, bubonic plague, and the epizooty known as surra. The severity of these visitations was aggravated by a series of disasters that had preceded them, with the result that the period of my administration, extended beyond the usual limit by the wish of the Legislature, was a period of continuous misfortune hardly perhaps paralleled in the history of our Crown colonies.

Early in 1892 Mauritius was visited by a hurricane which in a few hours killed I,260 people, wounded 4,000, rendered 50,000 homeless, knocked 
down twenty-four churches and chapels, and many public buildings. On the sugar estates it destroyed many mills, with their costly machinery, and reduced a promising crop by one-half. In order to appreciate the effects of this hurricane, it must be borne in mind that there are in Mauritius few accumulated fortunes; capital is almost exclusively domiciled in Europe, and, as regards the Indian traders, in India. The bulk of the community lives on the annual proceeds of the sugar crop, from which source are derived public and private salaries, professional emoluments, and the wages of the working community.

In 1893 a great fire lapped up what the hurricane had left in the principal business area of Port Louis.

Against these appalling disasters the general community struggled with a courage worthy of the great traditions of Mauritian history. In the Indian community the merchants exercised a generosity which earned the grateful acknowledgment of the colony and the thanks of the Imperial and Indian Governments. At the other end of the social scale, the indentured labourers on the estates volunteered to accept a reduction of their statutory wages.

Misfortunes never come single-handed. There followed a short crop, an enhanced cost of supplies from India due to famine and plague, and allied complications leading to a financial crisis. It had to be met by Government assistance to the banks, a loan to planters (punctually repaid with a margin of profit), and the suspension of specie payments, measures of grave anxiety, only justified by the peril they successfully averted. 
It was hardly averted when an epidemic of plague broke out, which fortunately did not find the colony unprepared. In April, 1897, a medical officer of the Government, Dr. Lorans, who had devoted himself to the science of bacteriology, was sent on a mission to Bombay to study the subject of plague prophylaxis and treatment, and the itinerary of the disease was carefully watched by communications with India and Madagascar. In June, I898, I received a communication respecting plague measures adopted by the Government of India and published in the Calcutta Gazette, and a plan of campaign based on this information was at once organised. It included legislation dealing with quarantine and infectious diseases, the creation of isolation hospitals and segregation camps, regulations for supervision and inspection, measures for the destruction of rats and vagrant animals, and the issue of instructions to the public. The instructions were printed in English, French, Indian dialects and Chinese, and gave simple rules to be observed by householders to guard against infection, indications of the symptoms of the disease and precautions to be taken. Meantime, in July, I had written to the Government of Bombay, asking for full information on the use of Haffkine's prophylactic virus. On November 23 rd information was received from H.B.M. Consul in Madagascar of the outbreak of plague in Diego Suarez. On November 3oth the Consul telegraphed that plague had appeared at Tamatave. On December 28th I addressed a despatch to the Secretary of State informing him of the measures adopted, and trans- 
mitting copies of the Quarantine and Infectious Diseases Ordinances. On January 25th the first case of plague was reported, and I at once appointed a Plague Committee to sit de die in diem, and keep me advised as to the best measures for stamping out or dealing with the progress of the disease. The Secretary of State was kept constantly informed of the action taken, and in March, I was glad to bring to Mr. Chamberlain's notice the services rendered by the Plague Committee, the Medical Department, and the Municipality of Port Louis.

\section{"Government House, "Mauritius, I4th March, I899.}

"I avail myself of this opportunity to express my thanks to Sir Graham Bower and the following members of the Plague Committee for the admirable service they have rendered the Colony during a period of difficulty and anxiety.

The Honourable F. T. Piggott,

The Honourable J. F. Trotter,

The Honourable W. T. A. Edwards, M.D.,

The Honourable V. Rohan,

The Honourable E. Chastellier, M.D.,

Colonel Fraser, M.D., Royal Army Medical Corps,

C. E. Thomy Pitot, Mayor of Port Louis,

H. Lorans, M.B.

"To Sir Graham Bower my thanks are also due for the constant supervision he has exercised over the carrying out of the measures adopted and the tact and judgment with which he has secured the 
co-operation of all concerned in the protection of the public health.

"Dr. Chastellier, Director of the Health Department, has been indefatigable in his exertions, in the framing of Orders under the provisions of the Infectious Diseases Ordinance, 1898 , in the detection of cases, in the arrangement of the segregation hospitals and camps, and in the disinfection of contaminated areas and premises. And he has been ably assisted by the principal members of his staff: Dr. Lorans, Medical Inspector, Drs. Bolton and Barbeau, Sanitary Wardens, and Dr. Momplé. Dr. Lorans's experience, when on his mission to study the plague in India in 1897 , has been invaluable.

"Nor must I omit to mention the services rendered by the Surveyor General, Mr. de Coriolis, and by the Storekeeper General, Mr. du Vergé, in the construction, furnishing and provisioning of the segregation camps and hospitals. Their zeal and industry in all they had to do has been beyond praise.

"It gives me pleasure to add that the Mayor of Port Louis, Mr. Pitot, and the Municipal Councillors have co-operated with the Government in a spirit of perfect good-will."

Mr. Chamberlain, who has always appreciated the service of Colonial communities as service to the Empire, was generous in the terms of his reply.

"Downing Street, “26th April, I 899.

"I have read with much satisfaction your expressions of commendation of the services rendered by 
the members of the Plague Committee, especially by Sir Graham Bower, and your account of the careful work which has been done by the Director of the Health Department and the principal members of his staff, as well as by the Surveyor General and the Storekeeper General. It is most gratifying to be assured that, in a time of such stress and danger, the members of the Public Service have responded so earnestly to the calls made upon them: and to learn of the valuable co-operation of the Mayor and Municipal Council of Port Louis, and of the Elected Members of the Legislative Council who have served on the Plague Committee.

"I trust that you will convey to all the gentlemen, who are mentioned in the last of your despatches under acknowledgment, my thanks for their exertions in the interest of Mauritius on this occasion.

"I am, however, well aware that a great part of the credit for the successful organisation of the measures for minimizing the effects of the outbreak is due to yourself, and I have much pleasure in recording my appreciation of the energy and ability with which you have supervised the work of all departments at such a critical period."

In the meantime, however, the progress of the plague had been followed by consequences which for a time imperilled the peace of the community. Apart from the fatality of the disease, which, so far at least as the Asiatic community is concerned, is perhaps the smallest of its terrors, it is attended by subsidiary difficulties and dangers arising largely out of the measures adopted to arrest its progress. 


\section{THE BROAD STONE OF EMPIRE}

These are now getting to be understood in this country by the records of experience in India. They affect smaller communities with even more acute severity, and they strained the courage and resources of the colony in a way that can hardly be realised by those who have had no similar experience. The main difficulties arose, as often happens in times of public danger, from two conflicting causes. The Asiatic community, fearless of death, resisted inoculation by prophylactic virus, and the measures adopted to arrest the spread of the disease, such as segregation of contacts, and compulsory evacuation or burning down of premises. A chokra, an Indian boy, almost a child, in the service of an officer, illustrated the Asiatic sentiment in replying to the officer's wife who had asked him whether the people in the "camp," the servants' quarters, were much afraid ; "What for afraid, memsahib, must all dead." On the other hand, a small section of the non-Asiatic community, in terror of the disease, demanded, not without some violence of demonstration, drastic measures, compulsory inoculation of Asiatics and the burning down of a large infected area. While every effort was made to encourage voluntary inoculation, the Government steadily opposed compulsion, and every precaution was taken to prevent the operation from being performed except by experts using genuine serum. The wisdom of this course was amply justified by subsequent experience in India, where compulsory inoculation and the accidental use of improperly prepared serum were followed by disastrous consequences.

Mr. Sydney Low, in his Vision of India, has 
given an engaging picture of the memsahib, and the cheerful alacrity with which she adapts herself to the exigencies of plague and other perils in India. In Mauritius the ladies were equal to the occasion. In order to encourage inoculation among their servants and others, many were themselves inoculated. The use of Haffkine's virus produces a swelling, often as large as a fowl's egg, which lasts for some weeks. It was a singular experience to watch the ladies in frank enjoyment at parties and balls, with what Charles Lamb might justly have called "these amiable excrescences" on their arms.

From the very first, before the actual outbreak of plague, the Government had realised the formidable difficulties it would have to encounter from the fact that the colony was overrun with rats, the principal carriers of infecting parasites. It was a tradition that the Dutch had been driven out of the island by these rodents, which they must share with the Portuguese the responsibility for having introduced on their vessels, during a period when it was used only as a port of call for the repair and supply of their shipping. There are conditions in the formation of Mauritius, with its deep afforested ravines, which make it extremely hard to deal with rats, and the cost of endeavours to destroy them has always been a heavy burden on the planters. The fundamental difficulty is that the rat, not being indigenous, has no natural enemies, while the introduction of such enemies is attended with recognised dangers. In earlier years the introduction of snakes had been frequently suggested 
and, with reason, rejected. My experience in Ceylon inclined me to favour the introduction of the mongoose, an animal associated in history and fable with the destruction of snakes, rats, and noxious reptiles in India. But my experience in the West Indies had taught me the disastrous consequences that have followed the multiplication of this little creature. After full consideration, a number of mongooses were introduced from India and supplied to Government institutions, every precaution being taken to prevent their overmultiplication. At the same time, South Africa was requisitioned for owls. I need not dwell on these enterprises. I only wish to make it clear that, apart from the consideration of other measures of prophylaxis and treatment, the Government was keenly alive to the importance of dealing with the agents of infection and propagation.

With the progress of plague its terrors increased, and in July I decided to summon a special meeting of the Council of Government, and invite their co-operation. I explained the position in the following terms ;

"On the I6th of May last you adopted the Report of a Special Committee appointed to consider and report whether any, and, if any, what measures might be deemed necessary to stamp out the plague. The recommendations of the Committee dealt chiefly with the measures that seemed best calculated to combat the plague in an area of the Eastern Suburb at that time known as 'the infected area,' and the only then well-defined focus of the disease. 
"It was foreseen, however, that circumstances might arise which would require a reconsideration of the measures to be adopted in dealing with them.

"The recommendations of the Committee have up to the present time been generally followed in dealing not only with the Camp Yoloff, the first infected area, but with new points of contamination that have since been discovered.

"The time, however, has now arrived when the points of contamination have spread over so large an area of the Town of Port Louis that in the opinion of the Director of the Health Department it has become impossible and, even if possible, impolitic, to apply them further without a very material modification of the methods that have been followed. A recent writer in The Times has pointed out that whether in South Western India or in Central or Northern or Eastern India the verified facts leave no hope of stamping out the plague by the methods adopted in the earlier experimental stages of dealing with a disease which, when once it has established itself, cannot be dislodged by any spasmodic application of force.

"The Government of India has therefore decided no longer to continue a campaign of evacuation and severe compulsory segregation such as has already caused panic and a resistance only to be overcome by armed force. It seems to be of the essence of the new policy adopted in India to have recourse only to measures in which the Medical and Sanitary Department can reasonably hope to have their efforts seconded and supported by the consent and 


\section{THE BROAD STONE OF EMPIRE}

confidence of the community. That is the policy which it is my hope that the Council of Government may find a means of carrying out in Mauritius. For our experience here, as in India, indicates that for a large section of the community, death from plague seems to have less of terror than the measures which it would be necessary to enforce were it decided to adhere to methods, which, however appropriate they may have been to the circumstances of a few weeks ago, are now found to be inappropriate to an entirely altered range of circumstances.

"It is not my desire to anticipate the recommendation of the Special Committee, which I hope you will agree to appoint, by discussing the details of a new policy, but I may be allowed to suggest that it may include :-

"( I) A discretionary power to the Medical Department to permit the isolation and treatment of patients in their own residences on suitable conditions, both as regards the patients and relatives or others attending them, or to move them to a hospital for treatment whenever such a course seems desirable in the interest alike of the patient and of the community ;

“(2) The encouragement of inoculation by granting special privileges to persons who have been inoculated with Haffkine's prophylactic;

"(3) Large measures of sanitation, especially in connection with the sanitary improvement of Common Lodging Houses and the homes of the poorer classes of the community.

"It will also be for the Committee to consider by 
what means it may be possible to secure the safety of the community without the dislocation of commerce, which would probably be the consequence of closing commercial establishments in the way that a strict adherence to the methods hitherto adopted would make obligatory.

"In choosing the machinery of a special Committee of the Council of Government composed almost entirely of unofficial members, to deal with the vital questions which will be submitted to you, I need hardly say that it is my object to secure to the Medical Department the confidence of the community, and I know of no way in which that confidence can be secured except by obtaining for the measures to be carried out by the Department the consent and confidence of the representatives of the community in the Council of Government. A few weeks ago you expressed your appreciation of the energy and devotion showed by the Department in dealing with the earlier stages of the plague, and all that has since occurred seems to justify me in saying that we have in the Staff of the Department as noble a little band of workers as could have been found to fight the plague in any part of the Queen's Dominions."

Meanwhile the general unrest of the community was finding expression in complaints against the medical officers and others who were devoting themselves in a spirit of unselfish self-sacrifice to the public good. I determined, therefore, to pay a visit to the plague hospitals and segregation camps, and reported the results to the Secretary of State. 
"Government House, “Mauritius, I 4th August, I 899.

"With reference to my despatch of the 28 th July last reporting the progress of plague up to that date, I have the honour to inform you that representations having been made to me to the effect that the patients in the Government Plague hospitals were not receiving the care and attention they required, and that the inmates of the segregation camps had been treated with unnecessary harshness, I thought it advisable to pay a surprise visit to the different hospitals and camps, in order to satisfy myself of the justice or otherwise of the representations made to me.

"I accordingly paid a surprise visit to the hospitals and segregation camps on Monday, the 3oth July. I am happy to be able to inform you that all the patients in the hospitals as well as the relatives who were attending them, expressed their gratitude to the Medical Department for the kindness and care they had received. I interrogated all the patients in the hospitals on that day, between twenty-five and thirty, who were not too ill tc speak for themselves as well as the relatives in attendance; and I may say that some of the women seemed to express the opinion of all, when, pointing to Dr. Lorans, who accompanied me, they exclaimed repeatedly 'C'est le Bondî (Bon Dieu) même pour nous.'

"I also interrogated the inmates of the segregation camps as to their treatment on removal from their houses to the camps, and as inmates. In no 
single instance was any complaint made. All expressed their gratitude for the kindness and consideration shown to them.

"In each of the Government plague hospitals I found Sisters of Mercy whose services had been placed at the disposal of Government by Bishop O'Neill, Bishop of Port Louis, and I gladly availed myself of the opportunity to thank them on behalf of the colony for their self-sacrificing labour of love.

"In addition to the Government hospitals and camps I visited the hospital supported by the Chinese for the use of persons of their race. The inmates seemed to be receiving every care and attention.

"I enclose herewith a report from Dr. Lorans, from which it will be seen that since the date of my despatch above referred to there have been II 3 fresh cases of plague, of which eighty-eight were fatal.

"It is with great regret that I have to report the death of Mr. A. E. Johnson, of the Colonial Secretary's Office. . . . . . Mr. Johnson's case is, I believe, the first death from plague of a gentleman of pure European descent never having slept in Port Louis and residing in one of the healthiest parts of the colony. In consequence of Mr. Johnson's death all the despatches and records in the office in which he worked as clerk in the Despatch Branch are being disinfected, and it is for this reason that $\mathrm{I}$ am unable to quote the number of my despatch referred to in the first paragraph above." 
I may mention that one of the sisters whom I saw had been bitten in the hand by a plague patient in delirium. Her life was despaired of, but she recovered and at once returned with renewed zeal to her task.

Mr. Chamberlain replied:

$$
\begin{aligned}
& \text { " Downing Street, } \\
& \text { "2 2nd September, I } 899 .
\end{aligned}
$$

"I have the honour to acknowledge the receipt of your despatch, No. 3 Io of the it th ultimo, enclosing a report of the Special Committee of the Council of Government on Plague and of your despatch No. 3 I4 of the $14^{\text {th }}$ ultimo, giving an account of a surprise visit paid by yourself to the different plague hospitals and segregation camps.

"I have to express to you my deep regret at the death of Mr. A. E. Johnson reported in the latter of the above despatches.

"After perusal of the despatches under acknowledgment I feel satisfied that no effort has been spared by your Government to combat the spread of the plague in the colony.

"To yourself I have to convey my thanks and express my cordial appreciation of the devotion to the public good which has prompted you personally to visit the hospitals and camps with a view to ascertaining the condition of the inmates. I learn with satisfaction that all are being treated with every possible consideration and kindness.

"I would ask you to convey to Dr. Lorans my thanks for the loyal manner in which he is discharging his duties, and to the Sisters of Mercy 
who are engaged in nursing the sick, for the noble self-sacrifice which they are displaying."

I do not propose to follow the history of the plague in Mauritius further. In 1900 the violence of the epidemic subsided, and there was a period of entire quiescence extending over five months. In July there was a recrudescence, and this has been followed by annual outbreaks of more or less severity, coinciding generally with the harvest of the sugar crops; the cutting of the canes and the burning of the "trash" having apparently the effect of driving the rats out of the cane-fields into the estate camps and villages.

TROPICAL DISEASES OF ANIMALS

In 1902 the epidemic of plague was followed by an epizooty of the disease known as surra, which attacked horses, mules, and cattle with cruel severity, and from an economic point of view was more disastrous than the plague. In March the outbreak of a disease among bullocks was notified to the Government. The infected herd was at once isolated on its own grazing ground and the area proclaimed infected under the law of the colony. As the symptoms of the disease baffled the local practitioners, I placed myself in communication with the Governments of Bombay, the Cape, and Natal, and with our Consul in Madagascar, those countries being the sources of supply to Mauritius. On April I 7 th the disease was diagnosed in Mauritius by Dr. Aimé Lésur as surra, an infection of the blood by a fly-borne parasite of the class known as trypano- 


\section{THE BROAD STONE OF EMPIRE}

somes; this diagnosis was subsequently confirmed. Information as to the nature and treatment of surra was then obtained by telegram from the Cape, Natal, and Bombay, as well as from the Principal of the Royal College of Veterinary Surgeons in London and the Principal of the Veterinary College, New York. This information was acted on at once, but in the meantime the disease had spread among cattle, horses, and mules with alarming rapidity, and the proprietors of some estates, acting on advice received by telegram from the eminent pathologist, Dr. Laveran, had commenced the slaughter of diseased animals on a large scale. This advice was confirmed by the Government of Bombay on June $17^{\text {th }}$ in a telegram: "Slaughter of marked cases recommended; equines rarely recover ; flies carry infection." The question of compulsory slaughter had therefore to be considered, and it presented formidable difficulties. It was discussed by the Chamber of Agriculture, and a motion in favour of the measure opposed by a large majority. My Executive Council pointed out the difficulty of carrying out the proposal in view of the fact that vehicular traffic in Mauritius was to a large extent in the hands of many hundreds of Indian carters and carriole drivers whom it might require a whole army of inspectors to control. The carriole is the cheap two-wheeled cab of the colony. Nevertheless when the question was brought before the Council of Government a large majority supported a resolution in favour of the compulsory slaughter of all horses, asses, and mules markedly attacked with surra. Prior to the passing of this resolution, I 
had applied to the Government of India for the temporary services of a veterinary officer, but no officer of the class required could be spared. I had then requested the Governor of the Cape Colony, Sir Walter Hely-Hutchinson, to obtain for me, if possible, the services of Dr. A. Edington, Director of the Bacteriological Institute of the Cape, as adviser in the treatment of the disease, and he had informed me that his Government were willing to place Dr. Edington's services at my disposal. When, therefore, the resolution of the Council of Government was followed by determined opposition on the part of the Chamber of Agriculture in circumstances which would have made it almost impossible to carry out the measure, I consented to await the arrival of Dr. Edington before putting into force the regulations drafted to give effect to the resolution of Council. Dr. Edington reached the colony a few days later, and lost no time in reporting on the history and nature of the disease. He reported at the same time on his experiments in inoculation with a preparation of virus from the diseased gall of infected cattle. On the strength of these experiments, which undoubtedly did have the effect of ridding the blood of diseased equines of the trypanosomes, he strongly advised that the regulations which had been drafted for the compulsory slaughter of animals markedly affected with the disease should not be put in force. There can be no doubt of the sincerity of Dr. Edington's belief in his serum, which, had it realised his hopes, would have conferred a priceless benefit on the continent of Africa. Unfortunately it failed. Soon after he had left the colony, all 
the animals reported to have been cured died, and the regulations for compulsory slaughter were put into force with the universal consent of the community. But many precious weeks had been lost. Such was the fatality of the disease, that within a year it dislocated the whole system of transport by animal draught throughout the colony, and it became necessary to substitute, at enormous cost, a mechanical system of transport by means of light railways, surface and overhead, and automobiles. I shall describe in a later chapter the measures which had to be undertaken to meet this necessity.

In the meantime the consequences of the loss of animals affected not only the sugar industry, but every department of public and private activity, including the work of sanitation in both urban and rural districts.

An independent witness wrote of the courage with which this calamity was met in terms which I may well repeat: "When one knows the extraordinary courage with which planters, overseers, and labourers alike here have faced the plague, cattle disease, and torrential rains to which they have been exposed during the course of the last two years, and that planters have not shrunk from any sacrifice to maintain, and generally to maintain with intelligence, their estates; and when one knows and has seen the Indian labourers, owing to the dearth of draught animals, harnessing themselves to heavy carts and dragging them along the estate roads in the middle of the rains, willingly and cheerfully bearing all hardships to finish the crop, I cannot 
think that classes which show such spirit to maintain an industry, which is capable of doing well in fair competition with the world, should be allowed to sink; and that no hand will be held out to them in their time of trial."

During this period of adversity the popular conscience was guided and controlled by the influence of the unofficial members of Council, aided by the leaders of the Indian community within their sphere of influence. And fortunately the colony had in its civil service a body of men steeped in the sympathy of common interests with the sentiments of the people. In the strain put on the departments every demand was met with patience and industry, many pressing emergencies with conspicuous ability and fertility of resource.

\section{CAMPAIGN AGAINST MALARIA}

While the exigencies of plague and surra were exercising a constant pressure on the resources of the medical and health department, an organised and systematic campaign was carried on against malaria. In I908 Major Ronald Ross was sent to Mauritius by the Secretary of State to report on measures for the prevention of malaria. He has in his report done justice to the intelligence with which the campaign was conducted by the colonial experts. "When, in 1897-99," he writes, "the mode of infection by means of anophelines was discovered, Mauritius almost led the way in recognising the fact. As early as May, 1900, M. Daruty de Grandpré, Superintendent of the Museum, and M. d'Emmerez de Charmoy, assistant Superintendent, 
report that they have been following the work since 1899 : that they have found in Mauritius five species of culicines and three of anophelines; and that one of these, $P$. costalis, "has the same area of dispersion as the malaria of Mauritius.' The second year they published a most excellent paper on mosquitoes and their role in the propagation of malaria and filariasis. The anatomy and life history of the insects were investigated in detail, and recommendations for prevention made. I believe that Drs. Alfred and Aimé Lésur had been among the first in Mauritius to study the parasites themselves."

In I 900 an epidemic of malaria broke out on the central table-land of the colony, in a district hitherto considered a refuge, about I, 400 feet above sea-level. "The Government, with great promptitude," as Major Ross observes, appointed a Malaria Inquiry Committee, and of their work I will allow him to speak:

"It consisted of Dr. Lorans (chairman), Dr. Edwards, C.M.G., Dr. Rohan, Dr. Clarenc, Dr. Bolton, Dr. A. Lésur, and M. Daruty de Grandpré.

"The suggestions of the committee were not only quite up to date, but were as good as could be. Streams near Moka clogged with vegetation were cleaned out, and quinine was distributed; with the result that the epidemic ceased. Curepipe, Grandport, Savanne, and other localities were visited, and similar work was started in them. Later on M. d'Emmerez de Charmoy was appointed Technical Assistant to the Committee for the purpose of continuing the study of mosquitoes and their haunts, and for disseminating knowledge on the subject 
among the public. With the latter object in view, the Committee concluded its report with a set of instructions. The only defect that can be found in the work of this committee was that it was not generalised, nor continued long enough."

The last phrase suggests a few words of explanation. On July 28th, 1903, I forwarded to the Secretary of State a report of the Committee giving details of their proceedings during the years $\mathrm{I} 9 \mathrm{OI}-\mathrm{O} 2$, and a summary of their recommendations grouped under four heads.

I. Tending the sick.

(a) Opening temporary dispensaries in centres affected by malaria.

(b) Having supplies of quinine at all public schools, police and railway stations to be distributed gratuitously to the poor and sold to others at cost price, if there is no chenist shop in the neighbourhood.

(c) Opening a sanatorium for treatment of affected subjects.

II. Destruction of mosquitoes.

(a) Suppressing all pools of stagnant water or else facilitating the flow thereof.

(b) Utilising petroleum and other oils to destroy mosquito larvae.

(c) Cleansing all rivers, streams, marshes, canals, and enforcing the maintenance by riparian proprietors of all works undertaken by Government in this connection.

(d) Reafforestation of part of slopes of mountains.

(e) Planting environs of springs with trees. 
III. Protection of healthy against anopheles.

(a) Extending the closing by gauze of the doors and windows of all public institutions, hospitals, jails, etc.

(b) Isolation of fever patients in special wards to protect them from anopheles.

(c) Administration of quinine in small doses to the healthy.

IV. Instructing the public of the danger of neglecting the sick and in prophylactic measures, by the publication of a popular memorandum, and by placards and posters in English, French, and two Indian languages.

The summary enclosed in my despatch was arranged in parallel columns so as to show how far each of the recommendations had been carried out. I added :

"(4) In so far as the recommendations of the Committee have not yet been given effect to, the proposals of the Director are receiving consideration. With reference however to his remarks under the head of 'Destruction of Mosquitoes' (c) on the recommendation of the Committee in favour of legislation to secure the permanent cleaning and upkeep, by the riverains, of river beds and reserves, the necessary expenditure will be so large as to require grave consideration. What has been done in this direction by the Government is shown in the annexures to the Committee's Report and in a brief resumé drawn up by the Director, of which I annex a copy. 
"(5) It is certain that measures must be adopted to ensure the proper maintenance of the work done, which will otherwise be of no avail and will have to be re-undertaken at further heavy expenditure."

I enclosed also a copy of the memorandum published for general information and guidance, and as it may still serve as a model for use in other tropical regions, I reproduce it as an Appendix to this work.

Mr. Chamberlain in his reply, dated September 8 th, informed me that my despatch and its enclosures had been referred to the Malaria Committee then sitting in London, and added :

"I shall be glad if you will inform me what expenditure has been incurred by the steps which have already been taken to carry out the recommendations of the Committee, and I have also to request you to furnish me with an estimate of the cost which is likely to be involved in carrying out the proposals made by the Committee in regard to the permanent cleaning and upkeep of the river beds and reserves referred to in the $4^{\text {th }}$ paragraph of your despatch.

"I desire to take this opportunity of expressing my satisfaction at the interest which is being taken in this important subject."

I left the colony a few days after the receipt of Mr. Chamberlain's despatch, but I may say that if the work of the Committee was not continued long enough, the reason is to be found in Major Ross's report. His recommendations, after an exhaustive inquiry, were practically an extension of the work carried out on the recommendation of the Committee, and the estimates of cost he submitted 
involved a charge of over $£ 40,000$ for works on capital account, and an annual expenditure of about $£ 9,000$. The question of carrying out Major Ross's scheme had to be deferred for the report of the Royal Commission subsequently appointed to inquire into the financial and general condition of the colony.

COLONIAL COOPERATION WITH IMPERIAL AGENCIES

Concurrently with local research into malaria and other tropical diseases, the colony readily voted sums in aid of the London School of Tropical Medicine and of the Malaria Investigation Committee sitting in London. At the same time the education law of the colony was amended to provide that all Government scholars studying for the medical profession in England should be required to undergo a course of instruction at the London School. Meanwhile, I had appointed a Committee to consider a scheme for the erection of Government bacteriological and analytical laboratories. The Committee reported in favour of the scheme, and the Council of Government readily voted the necessary expenditure. Nor was the colony less ready to aid subsidiary agencies. Grants were voted in aid of the Colonial Nursing Association, and for the salary of a lady doctor for the service of a dispensary established for the treatment of females of Indian origin.

DRAINAGE AND WATER-SUPPLY

During my tenure of office a scheme for the drainage and sewerage of Port Louis, prepared by Mr. Chadwick, C.M.G., was carried out in an 
experimental area with such success, that a rather determined opposition to it, when first undertaken, gave place to an almost universal desire to have it extended to other areas. I was able therefore to submit to the Secretary of State a proposal which he approved for its immediate extension to a large area of the town.

Inseparable from health and sanitation is the supply of pure water, and this question has received much consideration. A considerable area of the colony is supplied with water by a system of conservancy known as the Mare aux Vacoas water works. To meet the growing requirements of this area and improve the quality of the water large sums were expended; while to meet the needs of the colony outside of the area District Boards were created by Ordinance, vested with all necessary powers for the construction, maintenance, and management of water works for the supply of the rural districts.

\section{LEGISLATION}

It will easily be understood that during the whole of this period the question of sanitation was the first concern of the Government, while the financial exigencies of the department year by year inevitably swelled the colonial budget. The necessity of this increased expenditure was recognised and provided for even in the most critical period of the colony's financial difficulties; with the improvement of the financial position the expenditure largely increased. During the year 1899 various tentative measures of legislation, to meet the emergencies of the 
moment as they occurred, were enacted, and in I900 these enactments were consolidated and amended in accordance with the knowledge acquired by practical experience, by the Sanitation Consolidating Ordinance.

\section{REORGANISATION OF DEPARTMENT OF HEALTH AND SANITATION}

The experience gained in I899 and I 900 made three things clear:

I. That the administration of the Public Health Ordinance of I $894-95$ had failed to secure in the town of Port Louis such sanitary conditions as might have made it possible to arrest, or at least to modify, the progress of plague ;

2. That since the outbreak of plague the very large expenditure incurred had failed to secure permanent immunity from dangerous sanitary conditions ;

3. That the increasing demands for sanitation throughout the colony pointed to the necessity of reorganising the Department.

In these circumstances I appointed a Commission of Inquiry of which the Procureur General, Mr. (now Sir) Francis Piggott, consented to act as chairman. After long and careful inquiry the Commission presented an exhaustive report. As a first step towards giving effect to the recommendations of the Commissioners, a scheme for the reorganisation of the staff of the department was proposed and the necessary expenditure voted.

I transmitted the report to the Secretary of State with an elaborate analysis, and my recommendations on various points, but my first anxiety 
was to secure the reorganisation of the staff with a view to make sanitation a separate branch of the department. For this purpose, I proposed to appoint an assistant director and chief sanitary officer, assisted by a sanitary engineer and a staff of assistants. The necessary expenditure was voted by the Council at the last meeting before I left the colony.

It was my hope that the staff would be reorganised at once, and that the further reorganisation of the department through the agency of a qualified staff would follow without delay.

I had not long been in England when the Secretary of State referred to me a proposal received from the colony that the scheme for the reorganisation of the staff should be postponed. This proposal, I understood, was approved by the Office, but Mr. Lyttelton on my advice decided that the scheme should be proceeded with. A few days after Mr. Lyttelton's decision was made known to me, I called to express my thanks, and the clerk who represented the Office, congratulated me on the success of my advice; he added, "I suppose you had read the report of the Commission which I have not?" It was a matter of as grave importance as ever affected the lives of a community. If I had ever had a doubt about the necessity of an advisory Council to assist the Colonial Office, the incident would have removed it.

\section{QUARANTINE}

In speaking generally of some imperial aspects of the study of tropical medicine, I have alluded to 


\section{THE BROAD STONE OF EMPIRE}

the formidable difficulties which confront a colonial governor in endeavouring to reconcile the interests of personal and family security with the exigencies of trade and shipping. So far as my experience goes, trade and shipping are dominating influences at the Colonial Office, and generally in the West Indies; in Mauritius the interests of home life are supreme,-and not without reason; for Mauritius has had painful experience of the introduction of diseases following the migration of labour, the import of animals, and the exigencies of commerce.

My experience of quarantine legislation in British Guiana and in the Windward Islands was sufficient to warn me of the difficulties I might expect in Mauritius.

In British Guiana a conference of delegates appointed by the Governments of the several British West Indian colonies was held in October, I 888 , to consider the question of a uniform system of quarantine. The result of the Conference was embodied in a draft Bill, not intended to represent a complete law on matters of detail, but mainly to indicate the lines which any new law on quarantine should follow. It was transmitted to the Secretary of State, and remained for many years under consideration at the Colonial Office, while the colonies were urgently pressing for some decision which would enable them to frame their quarantine legislation on a uniform system.

When I was appointed Governor of the Windward Islands in 1893 , the exigencies of an outbreak of yellow fever in one of the West Indian islands made it impossible to wait any longer, and I was 
able to pass laws providing for a uniform system of quarantine in Grenada, St. Lucia, and St. Vincent, based on the Bill drafted by the British Guiana Conference. So the labours of the Conference were not in vain.

The passing of quarantine Ordinances in Mauritius proved one of the most formidable legislative enterprises in which I have been engaged. Certainly no subject ever brought before the Council of Government was discussed more fully. The general principles of the quarantine Ordinances enacted were based on the resolutions of the Venice International Conference of 1892 and the Paris Convention of 1894 , and may be classed under three heads :

(I) The removal of all unnecessary causes of delay in the case of healthy vessels :

(2) The reduction of the period of quarantine imposed in the case of suspected or infected vessels:

(3) The introduction of a system of disinfection as a prophylactic measure in substitution for an unnecessarily extended period of quarantine.

In submitting the principal Ordinance to the Secretary of State, I pointed out that it had been my desire to pass a measure which would accord with the principles of the Conventions of Venice and Paris, and yet secure the adhesion of a community disposed to cling to the rigours of an older system by the calamities that had befallen it from the introduction of diseases of foreign origin. 


\title{
CHAPTER XIV
}

\author{
HEALTH
}

III

TROPICAL DISEASES THAT HAVE THEIR ORIGIN IN CIVILISATION

LoNG experience has led me to divide the diseases of the tropics into two groups, - those that have their origin in uncivilised communities, but are distributed through the agencies of civilisation, and those that have their origin in civilisation. So far I have been concerned mainly with the former group; and of the influence it is likely to exercise on the destiny of the human race in equatorial Africa, some idea may be formed from the evidence supplied by Uganda. For some years Uganda has been suffering from two diseases which threaten to exterminate the whole population,--sleeping sickness and syphilis. In 1908 it was reported that within seven years 300,000 of the inhabitants had died from sleeping sickness. Syphilis threatens to be an even more appalling visitation. From the report of Colonel Lambkin, R.A.M.C., appointed in 1908 to inquire into the subject, it appears certain that a main cause of the spread of the disease has been the emancipa- 
tion of the Baganda women, through the agency of European civilisation, from the restrictions in which they were formerly held. This opinion is held not only by the native Prime Minister of Uganda, but by both Catholic and Protestant missionaries.

I pass on to a consideration of the most fatal of all forms of disease having their origin in civilisation, diseases arising out of the excessive use of spirituous liquors in European civilisation, and diseases arising out of the excessive use of narcotic drugs in Asiatic civilisation. The long battle of the Aryan race in Europe against the forces of nature and humanity promoted desires appropriate to the intensity of the struggle, alike in those who triumphed and in those who succumbed. The victor demanded a stimulus to his energy in the day of conflict and to his passions in the hour of victory. The vanquished found consolation in the narcotic effect of the extreme abuse of spirituous liquor. He took counsel of the words of King Lemuel that his mother taught him: "Give strong drink unto him that is ready to perish, and wine unto those that be of heavy heart. Let him drink and forget his poverty, and remember his misery no more."

In Asia it was otherwise. The climatic conditions of the Aryan race in their wars of conquest required and taught them to enforce total abstinence from spirituous liquors. In peace the use of narcotics appeal to the always dominant sacerdotal caste as an agency to promote their own supremacy and to secure the obedience of subject communities. By the use of narcotics they sought to soothe and allay the passions that interfere with the enjoyment 
and aim of a purely contemplative life, a thing of which the European has never had any conception. To the contemplative life of Asia we owe the origin of all European religions, laws, literatures, arts, and sciences. The restless energy of the European, the consequence of his climatic conditions, never left him time for original work in any one of these areas of human activity. And the contemplative life of Asia had another purpose, to enable man to keep himself unspotted from the world and so to fit himself for reabsorption in the supreme spirit of the universe. On the other hand, the use of narcotics has helped to reconcile the conquered peoples of Asia to the law of obedience which centuries have ingrained into their nature. As conqueror succeeded conqueror,-

"The East bowed low before the blast,

In patient, deep disdain;

She let the legions thunder past

Then plunged in thought again."

I will deal first with the operation of diseases arising out of the use of spirituous liquors. One of the first fruits of the reformed Parliament of 1832 was the appointment, in 1834 , of a Committee to consider our relations with uncivilised nations. The Committee reported in 1837 , and presented a formidable indictment of the consequences of European intercourse with natives "without any exception of the subjects of Great Britain. ... European vices and diseases have been introduced amongst them, and they have been familiarised with our most potent instruments for the subtle or the violent destruction of human life, namely, brandy and 
gunpowder." The publication of the report was immediately followed by the establishment of the Aborigines Protection Society, which has ever since devoted itself to a propaganda against the "subtle instrument"; and not without good results, although after sixty years of united effort, we are confronted by the fact that the currency of a considerable area of British territory in equatorial Africa is avowedly gin.

From the recent report of a Committee of Inquiry, it appears that in Southern Nigeria practically the whole of the taxation is raised by means of Customs duties. In 1906 the import of spirits represented 24.2 per cent. of the total inward trade. In the same year, the total revenue of

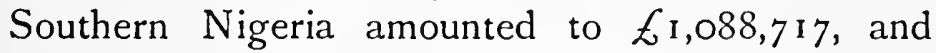
the revenue derived from spirits to $£ 608,784$, more than one half of the whole. The report of the Committee has established the degeneration of festival plays and funeral processions into drunken orgies; the custom of pawning children for gin; the use of gin as currency not only in trade but officially in payment of fines imposed by Courts of Justice. And yet it is to Africa that the energies of the Society have been particularly devoted, because, as they justly urge, "the expansion of European control in Africa, for good or for evil, with honour and gain, or with loss and discredit, have in recent years been very much greater and more notable than in any other part of the world." I will, however, confine myself to the question of the use of alcoholic drinks in Crown colonies within the range of my own experience,- 


\section{THE BROAD STONE OF EMPIRE}

colonies in which the native element is partly of African and partly of Asiatic origin, and in which it has been for generations in contact with and under the direct influence and control of European administration. At the outset, I am bound to say that, in my opinion, while the standard of sobriety in the African element compares favourably with the standard of sobriety in the United Kingdom, the standard of sobriety in the Asiatic element, taking due account of the use of opium or gandhia, is much higher. Nevertheless, the problem of dealing with the consumption of intoxicating liquors in the group of Crown colonies with which I am concerned is not without its difficulties, and a main difficulty lies in the relation of the consumption of alcohol to their fiscal system. This will be easily seen by reference to the proportion of revenue derived from the drink traffic to the total revenue. The following figures have been supplied by the Colonial Office. The revenue from drink traffic, including Excise duties and duties of Customs, is given as follows :

Ceylon, i 905 .

Total Revenue - - . -

Rs. $34,395,336$

Revenue from drink - - - $\quad 4,863,63^{2}$

Approximate proportion, one-seventh.

Mauritius, 1904-05.

Total Revenue - - - - Rs. 10,399,555

Revenue from drink - - - $\quad 1,717,837$

Approximate proportion, one-sixth.

British Guiana, 1905-06.

Total Revenue - - - - $£ 522,493$

Revenue from drink - - . 124,623

Approximate proportion, nearly one-fourth. 
WindWARd ISLANDS, 1905-06.

Total Revenue

Eir 7,149

Revenue from drink

29,789

Approximate proportion, one-fourth.

In St. Lucia the proportion was over one-third.

In all these colonies, as in the Crown colonies generally, the fiscal system has aimed at raising the largest revenue possible from the liquor traffic by imposing the highest duties that the trade will bear without reduction of revenue. Many advocates of temperance would prefer to go to another extreme, and impose prohibitive rates. In dealing with the liquor traffic in Africa within the "spirituous liquor zone" marked out by the Brussels Conference, such a system may be possible; but in the group of colonies with which I am dealing it is not within the domain of practical politics. In my opinion, there is a third course,-a system which will place absolute control over the traffic in the hands of the Government, and convey to the public treasury the profits derived from the sale of intoxicants : eliminate from the traffic the motive to make private profit by encouraging consumption; and substitute pure liquor for the adulterated and injurious compounds often sold by private dealers.

It was the influence of Earl Grey in bringing to the notice of the colonial Governments the work of the Central Public House Trust Association that led me to consider the advantages which might accrue to the Crown colonies in dealing with the problems arising out of the drink traffic by adopting, and extending the principles of the Trust to 


\section{THE BROAD STONE OF EMPIRE}

what I believed to be their logical conclusion,- - a Government monopoly.

In I903 I brought the question forward in a Message to the Council of Government of Mauritius. After pointing out that the sale of rum for home consumption affected four interests, the producer, the consumer, the retail dealer, and the general community, I laid down the main lines of a scheme, which had been suggested some years before by an unofficial member of the Council of Government, but dropped :

"(I) All rum for home consumption made in Mauritius to be sold by the Government in approved stores or warehouses.

“(2) The Government to fix the price.

"(3) The distillers to receive a percentage of the gross proceeds of sales.

"(4) The balance of profit to accrue to the Government in lieu of excise duty.

"If a Board of Commissioners were appointed to fix the price, as would be necessary, the distillers would under such a scheme be able to rely on a certain fair profit instead of being exposed to constantly shifting fluctuations depending on the more or less successful ingenuity of the promoters of 'accords,' (corners or trade combines).

"The position of the dealers would, of course, be materially modified under the scheme, but the change would, in the Governor's opinion, be of material advantage to the Mauritian community. At present the profits of the retail spirit trade are almost completely monopolised by an industrious class of temporary residents who out of a small margin of 
profit accumulate what they deem an adequate fortune with which they return to their native country, so that practically the whole profits of the retail spirit trade leave the colony. In this branch of business it is certain that an alien immigration consisting almost exclusively of adult males free from the burden of family ties and duties has made the competition of the Mauritian Creole population impossible. And yet it is a business which under such a scheme as has been proposed would offer a field of employment to a section of the Creole community who would secure and put in circulation for the general benefit of the colony the whole profit of the retail trade.

"The advantage of the scheme to the consumer would be twofold.

"If the dealers were remunerated by a fixed salary the temptation to obtain large profits by process of adulteration would be sensibly diminished, and the risk of adulteration would be farther reduced by vigilant supervision and control. The consumer might, therefore, reasonably expect to be supplied with pure liquor at a reasonable price no longer liable to the capricious movements resulting from 'accords.' As regards the interest of the general community two advantages of the scheme have already been indicated: a fair field of employment for the permanently resident class and the retention within the colony of the profits of the trade. There must be added the interest of the entire community in the supply of pure liquor to customers, and a consequent reduction of the dangers arising from the use of adulterated intoxicants. But above all, 


\section{THE BROAD STONE OF EMPIRE}

the entire nett profits of the trade over and above the cost of purchase and distribution would form part of the general revenue of the colony and be appropriated in relief of the taxpayers.

"The Governor realises that the system suggested will require very careful consideration, and in no way desires to press its immediate adoption. He submits only that it is worthy the earnest attention of the Council of Government in the interests of all classes of the community."

I can only express my regret that it was not possible for me to carry the scheme further. In the serious financial difficulties which have led the Colonial Office to send a Royal Commission to Mauritius to inquire into the financial position of the colony, I am satisfied that it would provide a legitimate source of revenue, and would at the same time contribute to the cause of temperance. And I believe that in the principles underlying my proposal is to be found a policy which may be applied to the problem of dealing with the drink traffic throughout the Crown colonies.

I have observed with satisfaction that an analogous system has been proposed for dealing with the opium traffic in Ceylon. During the last few years there has been an anti-opium movement in the East supported by the British Government with an interest and energy that stand in singular contrast with our policy in 1860 . In that year we went to war with China to revenge the conduct of an official of the Chinese Government who, to prevent the importation of opium into that country, destroyed about $£ 2,000,000$ worth of it on landing. As a 
result of the war, we acquired the island of Hong Kong in part payment of the indemnity we extorted. We are now accusing the Chinese Government of a want of sincerity and vigour in putting down the opium traffic which we forced upon them, and find ourselves confronted with the fact that we have supported in Hong Kong a fiscal system which makes that colony largely dependent on the profits of opium traffic for the means of supporting a civilised Government. In the Straits Settlements and the Federated Malay States the increased consumption of opium under British administration has been extraordinary, as the following figures bear witness.

Revenue derived from Opium in Dollars.

\begin{tabular}{|c|c|c|c|c|}
\hline Year. & Singapore. & Penang. & Malacca. & Total. \\
\hline 1896 & $1,080,000$ & 600,000 & I 20,000 & I, $, 800,000$ \\
\hline 1904 & $4,245,000$ & $1,764,000$ & 306,000 & $5,826,000$ \\
\hline
\end{tabular}

In 1904 the total revenue of the Straits Settlements amounted to $10,746,518$ dollars.

Returns are not available for a similar table of comparison for the Federated Malay States, but from the figures available it appears that the revenue from opium has doubled during the same period.

The recent report of Lord Sanderson's Committee on Emigration from India to the Crown colonies and protectorates has called attention to the extent to which health in the Straits Settlements and the Federated Malay States is prejudiced by spirituous 


\section{THE BROAD STONE OF EMPIRE}

liquors as well as by opium. In his evidence before the Committee, Mr. T. Heslop Hill, formerly Protector of Labour in the Straits, speaking of the Indian immigrants, declared that "what they suffer from drink is intolerable." And he explained it in this way:

Q. 13,229. In the Madras Presidency they have got very good excise laws. If I go to Madras to-morrow I can go to any place where they sell liquor, I can get a sample of spirits, I can have it sealed, and I can take that away, and I can have it analysed, and if it is not up to a specific standard the man is very heavily fined. In the Malay Peninsula the coolie, having been used to drinking wholesome stuff in his own country, drinks something which he thinks is very nice-he is not a highly educated man-but he drinks the most arrant poison. The supply of intoxicants to the coolies near the estates is a question which has been brought up over and over again by the planters, and up to the time I left they were pressing very strongly for the laws to be amended.

The result as reported by the Commissioners is not surprising. Referring to the Straits Settlements they report, p. 37 :

I 56. The total number of deaths among the Tamil population of all four States in 1908 is given as 7760 , which, for an estimated population of 123,000 , gives an average of 63 per thousand.

157. The death-rates among the indentured immigrants are unfortunately still higher. According to the Report of the Immigration Department for 1908 , the deaths for that year in an average popula- 
tion of 6415 in all the four states were 511 , giving an average of 79.6 per 1000 . In the state of Perak, where the majority $(4983)$ of these indentured labourers were employed, the mortality was as high as 84.8 per 1000 . Among the free labourers in that state, numbering 7384 , the death-rate was lower, 48.9 per 1000 .

Nor is it surprising that these high rates coincide with a high percentage of desertion. The evidence of Sir Frank Swettenham on this point is instructive, p. 403. He said:

Q. 12,417. I read last night a statement from a manager of an estate in the Malay State of Perak, an estate to which the Government Immigration officer has given the very highest character, an estate where the death-rate was 4 per cent., which is extraordinarily low, and he says that in the course of twelve months 800 people had left the estate.

1 2,4 1 8. You consider 4 per cent. a low death-rate? I consider it is extraordinarily low.

12,419. It is 40 per thousand? I think that is very low for Indian labourers in the Malay States.

Mr. Heslop Hill's evidence, Q. 13,229 to 13,232, seems to have been accepted by the Commission as conclusive proof that high death-rate and desertion are the alternatives of refuge from bad drink and bad management.

It is impossible to overestimate the importance of the bearing of the use of intoxicating drugs and narcotics on the problem of labour in the tropics.

In Ceylon the rapidly increasing consumption of opium has been the subject of repeated inquiry. 


\section{IO THE BROAD STONE OF EMPIRE}

On assuming the Government of Ceylon the British authorities either continued or imposed a Customs duty on opium amounting nominally to twenty-two and a half rupees per pound. In 1840 the duty was reduced to one shilling per pound; in 1885 it was raised to one rupee; in 1897 to two rupees, and in 1898 increased duty was imposed with a view to reduce the consumption. Meanwhile the imports of opium had increased from $1562 \mathrm{lbs}$. to $18,286 \mathrm{lbs}$. in 1897 , and the rapidly increasing revenue suggested large profits and an increasing number of consumers. In 1893 the Government received for licenses in the villages the sum of 4100 rupees, and in 1906 this sum had increased to 69,1 19 rupees; while Municipalities and Local Boards received 37,360 rupees in 1893 , and no less than 122,187 rupees in I 906 . In addition, the general revenue received in 1906 a sum of 37,770 rupees from Customs duty.

At the close of that year a Committee appointed by the Governor of Ceylon, in accordance with instructions from Lord Elgin, declared in their report that the religion of the vast majority of the Sinhalese (Buddhism) condemned the use of opium, and that the High Priest Sumangala, of whose services I have spoken in my chapter on education in Ceylon, had expressed his wish to see every licensed opium shop closed. They reported further that returns received by them showed that nearly 20,000 persons in the island were known to be addicted to the opium habit; and they expressed their opinion that if the existing system of distribution through licensed opium shops were continued there was the gravest risk of the habit becoming general 
amongst the native population of the island. They recommended, therefore, that all opium shops should be closed at the expiration of existing licenses, and that the importation, distribution, and sale of the crude drug be made a Government monopoly. This recommendation was accepted by the Government of Ceylon, and approved by Lord Elgin.

I may express a hope that my suggestion to make the retail liquor trade in Mauritius a Government monopoly may come to be adopted, and may be followed by a general acceptance of the principle, in the Crown colonies, both as regards spirituous liquors and narcotic drugs. 



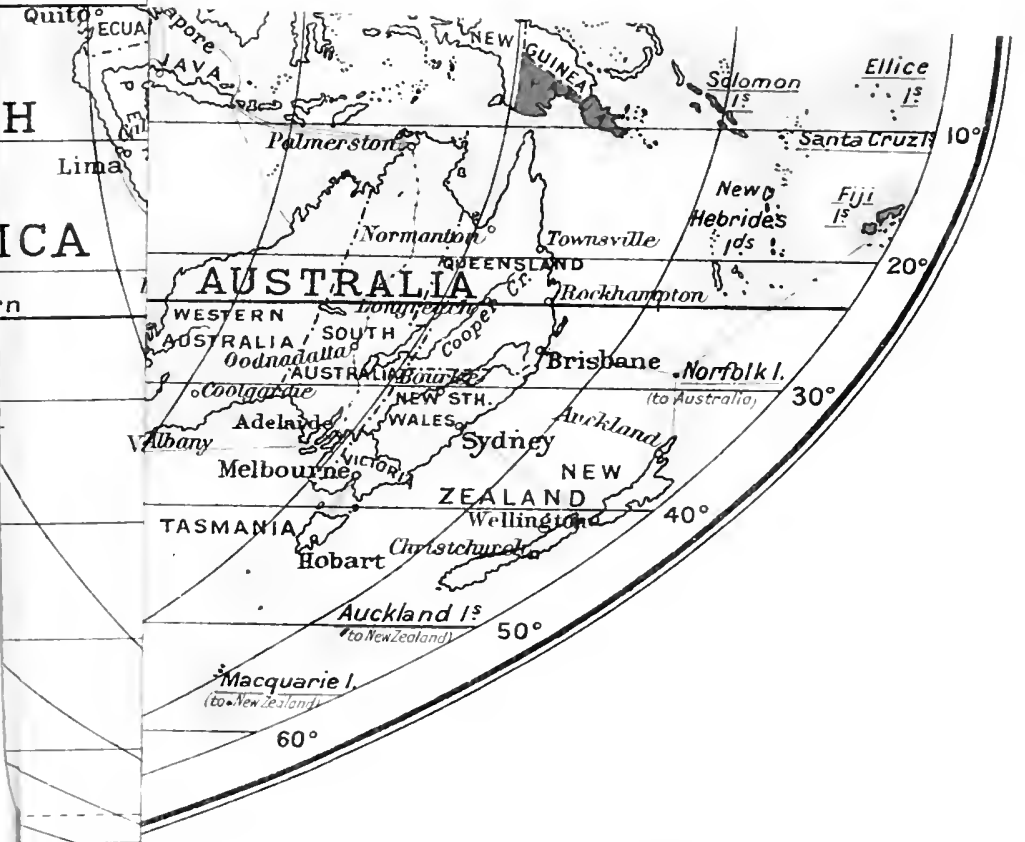

British Cables

United States Cable.

Telegraphic Lines 
MAP OF THE WORLD SHOWING THE BRITISH EMPIRE

ON MOLLWEIDE'S PROJECTION

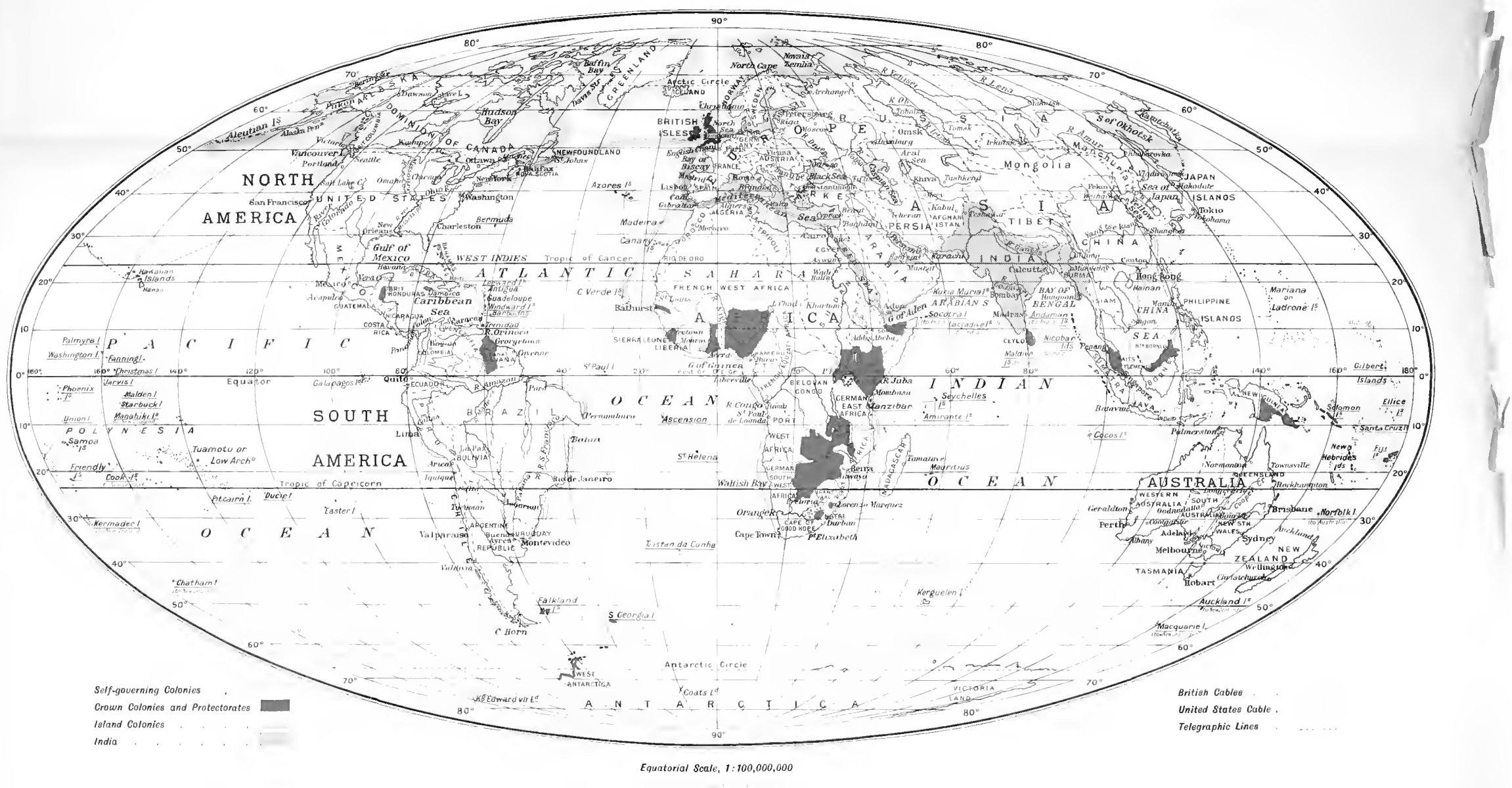





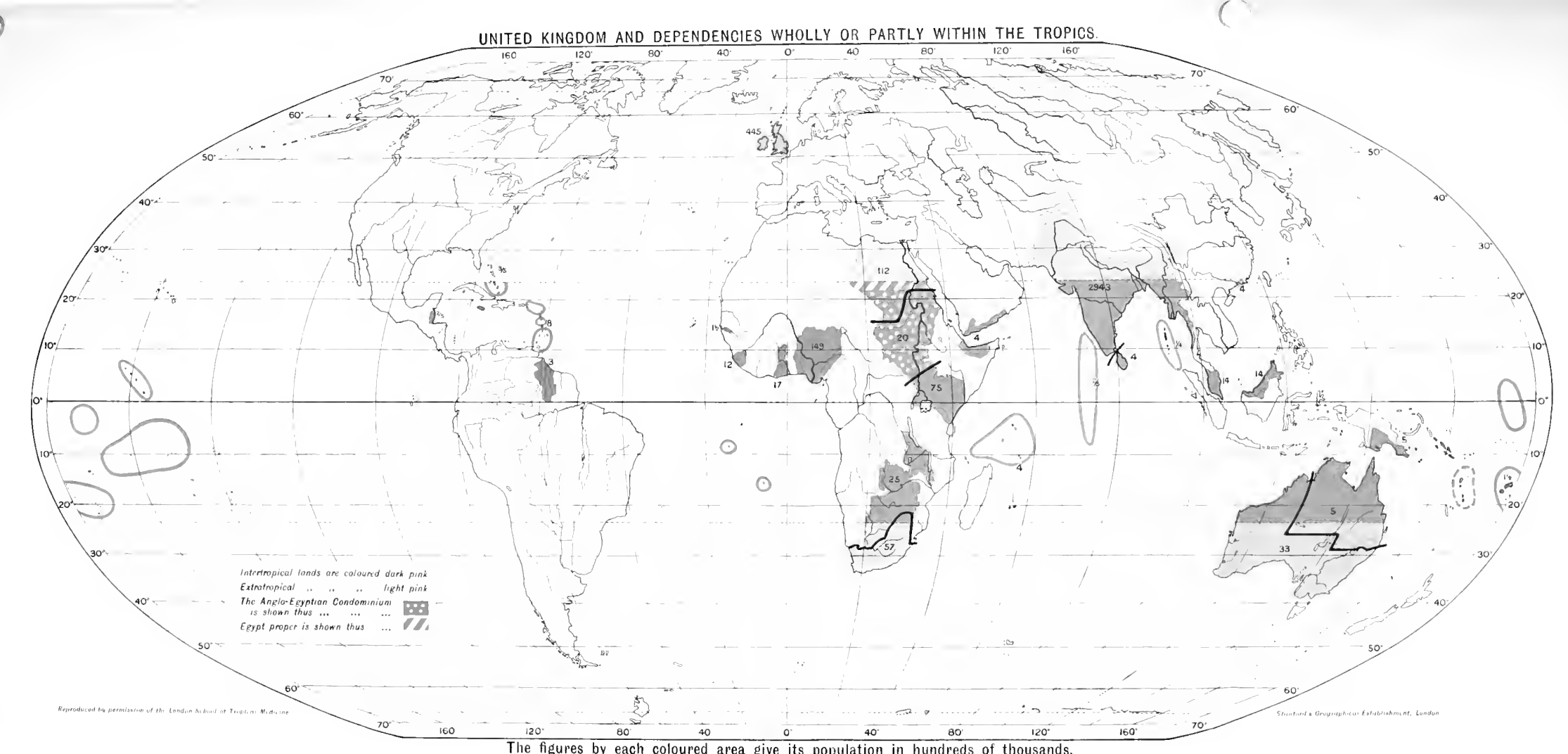

The figures by each coloured area give its population in hundreds of thousands. 
This book is DUE on the last date stamped below

University of California SOUTHERN REGIONAL LIBRARY FACILITY 305 De Nave Drive - Parking Lot 17 - Box 951388 LOS ANGELES, CALIFORNIA 90095-1388

Return this material to the library from which it was borrowed. 
